UNIVERSIDADE DE SÃO PAULO

FACULDADE DE FILOSOFIA, LETRAS E CIÊNCIAS HUMANAS

DEPARTAMENTO DE LINGUÍSTICA

PROGRAMA DE PÓS-GRADUAÇÃO EM SEMIÓTICA E LINGUÍSTICA GERAL

MARCELO SEGRETO

\title{
A linguagem cancional do rap
}

(Versão corrigida conforme a Resolução CoPGr 6018)

São Paulo

2015 
UNIVERSIDADE DE SÃO PAULO

FACULDADE DE FILOSOFIA, LETRAS E CIÊNCIAS HUMANAS

DEPARTAMENTO DE LINGUÍSTICA

PROGRAMA DE PÓS-GRADUAÇÃO EM SEMIÓTICA E LINGUÍSTICA GERAL

\section{A linguagem cancional do rap}

(Versão corrigida conforme a Resolução CoPGr 6018)

\section{MARCELO SEGRETO}

marcelosegreto@yahoo.com.br

Dissertação apresentada ao Programa de Pós-Graduação em Semiótica e Linguística Geral do Departamento de Linguística da Faculdade de Filosofia, Letras e Ciências Humanas da Universidade de São Paulo para a obtenção do título de Mestre em Linguística.

Orientador: Prof. Dr. Luiz Augusto de Moraes Tatit

São Paulo 
Nome: SEGRETO, Marcelo

Título: A linguagem cancional do rap

Dissertação apresentada ao Programa de Pós-Graduação em Semiótica e Linguística Geral do Departamento de Linguística da Faculdade de Filosofia, Letras e Ciências Humanas da Universidade de São Paulo para a obtenção do título de Mestre em Linguística.

Orientador: Prof. Dr. Luiz Augusto de Moraes Tatit

Aprovado em: / 2015.

Banca examinadora:

Prof. Dr.:

Instituição:

Julgamento:

Assinatura:

Prof. Dr.:

Instituição:

Julgamento:

Assinatura:

Prof. Dr.:

Instituição:

Julgamento:

Assinatura: 


\section{Agradecimentos}

Ao professor Luiz Tatit, pela confiança e orientação valiosa.

Ao professor Walter Garcia, por despertar o interesse pelo rap e orientar o grupo de estudos de canção popular no Instituto de Estudos Brasileiros (IEB-USP) em 2011.

Ao professor José Miguel Wisnik, pelo exame do trabalho final.

Aos professores Ivã Carlos Lopes, Waldir Beividas e Norma Discini pela contribuição para meu crescimento intelectual e científico.

A Ricardo Teperman, por dividir a revisão de seu último trabalho, o que muito contribuiu para esta pesquisa.

Ao Conselho Nacional de Desenvolvimento Científico e Tecnológico (CNPq), pela bolsa concedida para a realização deste trabalho. 


\section{Resumo}

SEGRETO, Marcelo. A linguagem cancional do rap. 2014. Dissertação (Mestrado) Faculdade de Filosofia, Letras e Ciências Humanas, Universidade de São Paulo, São Paulo, 2014.

Este trabalho tem como objetivo analisar o rap a partir da perspectiva teórica da semiótica da canção, abordagem desenvolvida por Luiz Tatit em seus estudos desde a década de 1980. Amparado por princípios da semiótica francesa de Greimas e Zilberberg, o autor propõe ferramentas específicas de análise e define o verdadeiro trabalho artístico do compositor popular: a formação de unidades entoativas plausíveis a partir da combinação entre uma melodia e uma letra. No processo de estabilização sonora que o canto produz em contraposição à instabilidade da fala, três procedimentos de compatibilização entre o texto linguístico e a linha melódica estão presentes: a figurativização, a tematização e a passionalização. Estudaremos a linguagem do rap a partir desses três procedimentos, observando de que modo as questões históricas e o seu papel social atual se relacionam com a sua forma estética particular.

Palavras-chave: canção popular, rap, semiótica da canção. 


\begin{abstract}
SEGRETO, Marcelo. The song language of rap. 2014. Dissertação (Mestrado) Faculdade de Filosofia, Letras e Ciências Humanas, Universidade de São Paulo, São Paulo, 2014.

This research aims to analyse the genre of rap within the theoretical framework of semiotics of songs developed by Luiz Tatit since the 1980s. Based on principles of Greimas's and Zilberberg's French semiotics, Tatit proposes specific theoretical tools to analyse songs and defines the artistic work scope of popular composer: to produce a credible relation between melody and lyric. According to him, through the process of sound stabilization that is produced by chant in opposition to the instability of speech, there are three possible compatibility procedures: figurativização, tematização, and passionalização. The genre of rap has been studied considering this analytics method and its social role and historical questions in relation to its particular aesthetical structure.
\end{abstract}

Keywords: song, rap, semiotics of song. 


\section{Sumário}

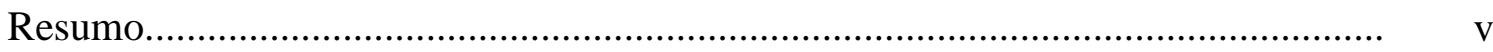

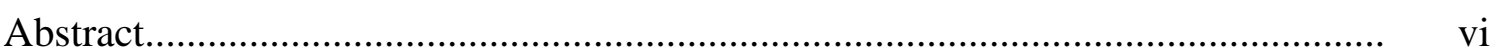

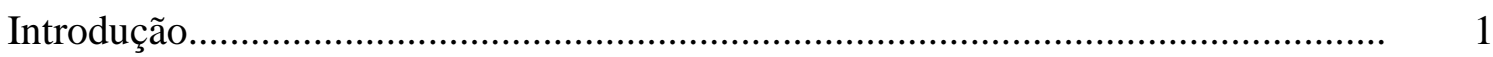

1 Figurativização

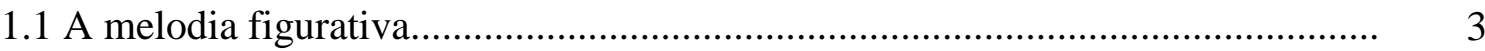

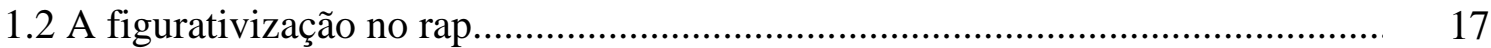

2 Tematização

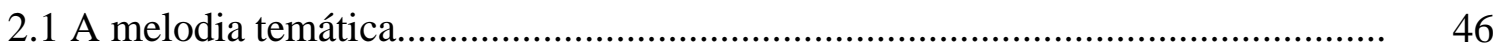

2.2 A tematização no rap................................................................................... 51

3 Passionalização

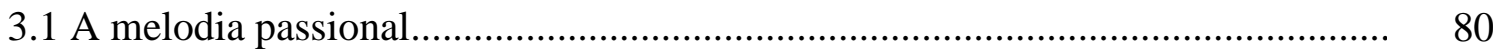

3.2 A passionalização no rap............................................................................... 86

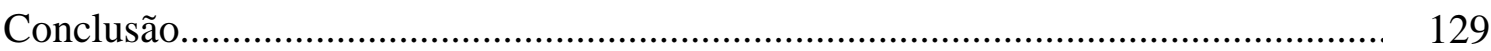

Referências bibliográficas................................................................................... 134

$\mathrm{CD}$ (exemplos musicais) ................................................................................... 137

Roteiro e discografia dos exemplos musicais...................................................... 138

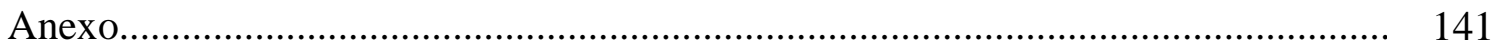




\section{Introdução}

A canção popular vem conquistando, desde o início do século $\mathrm{XX}$, uma posição extremamente significativa dentro da cultura brasileira. Suas inúmeras fisionomias, sua relação simultânea com o mercado e com a cultura erudita, suas intersecções com outras artes, além dos fatores sociais e políticos ligados à sua história, tornaram muito complexo e fascinante o seu estudo. A sua riqueza e importância cultural desperta o interesse de intelectuais das mais variadas áreas. No meio acadêmico esse gênero artístico mobiliza diversas linhas de pesquisa. Há, entre outros, enfoques históricos, sociológicos, literários, musicais e, mais recentemente, cancionais.

Adotaremos nesta pesquisa essa última perspectiva. Trata-se da abordagem da canção popular realizada por Luiz Tatit em suas publicações desde a década de 1980. Em oposição à tendência mais comum de se analisar a canção a partir da teoria da literatura ou da música, o autor propõe um olhar teórico específico, amparado por princípios da semiótica francesa. Tatit concentra-se no que afirma ser o principal elemento gerador de sentido para a canção popular: a relação entre a melodia e a letra. Sua teoria significou um grande passo no sentido de proporcionar ferramentas específicas de análise e explicitar o verdadeiro trabalho artístico do compositor popular: a formação de unidades entoativas plausíveis ${ }^{1}$ a partir da combinação entre uma frase verbal e uma frase musical. Segundo o autor, no processo de estabilização sonora que o canto produz em contraposição à instabilidade da fala, três procedimentos de adequação entre o texto linguístico e a linha melódica se fazem presentes: a figurativização, a tematização e a passionalização. Por isso, dividimos este trabalho em três partes, cada uma delas dedicada a um desses procedimentos de compatibilização. Como forma de descrever e traduzir os sentidos produzidos pela canção rap, também nos apoiaremos em modelos de análise da semiótica francesa de Greimas e Zilberberg. Nesta introdução, comentaremos as linhas gerais desenvolvidas ao longo da dissertação.

No primeiro capítulo, abordaremos de modo geral o processo da figurativização, no qual a fala coloquial aparece no canto de forma mais explícita. Comentaremos a

\footnotetext{
${ }^{1}$ O termo "plausibilidade" é empregado por Luiz Tatit em suas aulas na Faculdade de Filosofia, Letras e Ciências Humanas da USP. Segundo o autor, a experiência de escuta de uma canção ocorre a partir de parâmetros de plausibilidade pré-estabelecidos culturalmente. Assim, é comum encontrarmos no universo da canção popular comercial obras que apresentam unidades entoativas plausíveis, isto é, "aceitáveis" ou "verossímeis" do ponto de vista da nossa experiência cotidiana com a língua oral. Estudaremos esse assunto de forma mais detalhada no primeiro capítulo desta pesquisa.
} 
questão do envolvimento do ouvinte, da eficácia comunicativa na relação entre cantor e público e estudaremos as fases entoativas, os tonemas e as construções cancionais com menor controle musical do texto. Em seguida, examinaremos a figurativização no rap ${ }^{2}$. Constataremos as explorações mais radicais da fala, com a presença de falas diretas sem qualquer estabilização musical. Faremos uma descrição detalhada das divisões rítmicas mais comuns no canto dos MC's e veremos exemplos em que se destaca o uso de registros diferentes de altura. Analisaremos ainda a presença da fala na história do gênero e de que maneira essa predominância figurativa do rap está intimamente ligada ao seu caráter de denúncia, à relação entre o autor e o público e à relação entre o compositor e a obra.

No segundo capítulo, trataremos da tematização, processo de junção entre melodia e letra no qual observamos uma reiteração e regularidade de padrões rítmicomelódicos, geralmente pela necessidade de materialização de uma ideia ou tema. Posteriormente, analisaremos o procedimento temático no acompanhamento instrumental do rap, examinando as bases construídas pelos DJ's, as suas técnicas e a sua relação com a soul music norte-americana, sobretudo no que se refere ao repertório de músicas dançantes. Estudaremos igualmente a presença desse recurso na melodia do canto, comentando os diferentes graus de estabilização musical do texto, tanto por sua configuração rítmica quanto pela exploração de recursos como a rima, por exemplo. Por fim, desejamos observar de que maneira essas construções cancionais baseadas na repetição de elementos também podem se relacionar com o caráter contestatório do hip hop.

No terceiro capítulo, estudaremos a passionalização, procedimento no qual há a exploração das durações mais alongadas, a ampliação significativa da tessitura do registro vocal e a maior presença dos saltos intervalares. Comentaremos exemplos de construções passionais nos refrãos do rap, nos seus vocais e linhas instrumentais e principalmente na própria entoação dos MC's. Traçaremos novamente uma ligação histórica com a soul music nacional e internacional na tentativa de encontrar as raízes desse teor passionalizante. Por fim, analisaremos ainda de que maneira essas questões formais podem estar ligadas ao seu forte caráter político.

\footnotetext{
${ }^{2}$ Em relação à escolha dos exemplos musicais utilizados nesta pesquisa, tendo em vista o seu caráter abrangente (já que desejamos analisar a canção rap de modo mais geral e não apenas estudar um grupo em particular), selecionamos um espectro amplo de artistas. Assim, o critério para essa escolha foi igualmente plural, o que permitiu trazer para este trabalho tanto cancionistas ligados à cultura da periferia quanto outros mais conhecidos da grande mídia.
} 


\section{Figurativização}

\subsection{A melodia figurativa}

Nesse item, abordaremos a relação entre a melodia da canção popular e a melodia da fala com intuito de apresentar a linguagem da canção propriamente dita, diferenciando-a da linguagem musical ${ }^{3}$. Para abordar esse tema, nos apoiaremos principalmente nos estudos de Luiz Tatit, dedicados à análise da canção brasileira com enfoque especial na questão da entoação e fundamentação teórica na semiótica francesa de Greimas ${ }^{4}$ e de seus continuadores.

Para o autor, sobretudo no Brasil, há uma forte relação entre a composição e interpretação da canção popular e a nossa fala cotidiana. Os processos de adequação entre a letra e a melodia na canção funcionam de maneira semelhante aos processos de adequação de uma frase verbal e sua entoação na língua oral. Assim, os cancionistas, de maneira inconsciente e espontânea, fazem uso das inflexões entoativas da fala, permitindo que a compatibilização entre o texto verbal e o texto musical seja eficiente do ponto de vista da naturalidade oral. Como falantes da língua materna, possuem, logicamente, grande facilidade em promover essa união com absoluta coerência. Obviamente, no ato da composição, os fatores musicais são também de grande importância. No entanto, no processo de junção entre melodia e letra o objetivo dos cancionistas é sempre produzir unidades entoativas plausíveis para os ouvintes, sejam elas mais ou menos musicalizadas. E essa remissão à fala pode ser naturalmente compreendida:

É produto de um hábito social. Seria impossível eliminarmos, no ato de composição, de interpretação ou de audição de algo que possui texto e melodia, nossa vasta experiência, acumulada durante todos os dias de toda a vida, com uma linguagem que também possui texto e melodia (TATIT, 1986:8)

Dessa forma, ao entrarmos em contato com qualquer tipo de canto composto por melodia e letra, esperamos inconscientemente encontrar nele características presentes na

\footnotetext{
3 Luiz Tatit utiliza o termo "cancionista" para diferenciar o compositor de canção popular do "compositor-músico", geralmente mais dedicado à área instrumental ou à música cantada em que a entoação da fala é deixada de lado em prol de uma formalização mais musical.

${ }^{4}$ Algirdas J. Greimas (1917-1992), linguista lituano.
} 
fala que ouvimos no cotidiano. E essa relação entre canto e fala garante a comunicação eficiente entre o cantor/compositor e o ouvinte: o gesto oral do cantor assume então um sentido de verdade, já que a maneira como o indivíduo se expressa na canção se aproxima da maneira como ele se expressa em seu dia-a-dia. No capítulo XII, “Origem e relações da música”, do Ensaio Sobre a Origem das Línguas, Jean-Jacques Rousseau (1712-1778) já investigava a relação da voz com a expressão direta das emoções: “os acentos são nela mais frequentes ou mais raros, as inflexões mais ou menos agudas segundo o sentimento que se acrescenta". ${ }^{5}$ Em outro fragmento, agora do capítulo XIV, intitulado "Da harmonia", temos mais claramente o estabelecimento de um elo entre a voz de quem canta e a voz de quem se expressa pela fala:

A melodia, imitando as inflexões da voz, exprime as lamentações, os gritos de dor ou de alegria, as ameaças, os gemidos. Devem-se-lhe todos os sinais vocais das paixões. Imita as inflexões das línguas e os torneios ligados, em cada idioma, a certos impulsos da alma. (ROUSSEAU, 1978:190)

Isso nos indica a motivação entoativa como algo extremamente caro à produção de música cantada. Ou seja, é um elemento importante para o envolvimento do ouvinte (que reconhece os torneios familiares de sua língua) com a obra. Assim, conforme Tatit, a relação entre a voz que fala e a voz que canta produz o encantamento e a eficácia da canção.

Antes de tudo, o que assegura a adequação entre melodias e letras e a eficácia de suas inflexões é a base entoativa. De maneira geral, as melodias de canção mimetizam as entoações da fala justamente para manter o efeito de que cantar é também dizer algo, só que de um modo especial. (TATIT, 2004: 73)

O autor destaca então o poder dessa remissão à fala. Comentando sobre a consolidação comercial da canção brasileira com o sucesso do rádio nas décadas de 1930 e 1940, observa que a entoação é fundamental para o envolvimento do público ouvinte, como forma de assegurar a credibilidade em relação ao enunciador e configurar os mais variados personagens.

\footnotetext{
${ }^{5}$ ROUSSEAU, 1978:186.
} 
Ela [a entoação] acusa a presença de um "eu" pleno (sensível e cognitivo) conduzindo o conteúdo dos versos e inflete seus sentimentos como se pudesse traduzi-los em matéria sonora. De posse dessa força entoativa, e valendo-se do poder de difusão das ondas radiofônicas, os cancionistas se esmeraram em fazer dos intérpretes personagens definidos pela própria entoação. Ouvia-se então a voz do malandro a voz do romântico, a voz do traído, a voz do embevecido, a voz do folião, todas revelando a intimidade, as conquistas ou o modo de ser do enunciador. (TATIT, 2004: 75)

Enfim, parece haver, por parte do público, a expectativa de sentir uma pessoa em sua aparência de vida real por trás da música da canção. E, de certa maneira, esse entrecruzamento das diferentes instâncias, quando no momento enunciativo cantor e personagem se misturam num único ser, não é algo valorizado apenas na canção popular. Mesmo na música erudita encontramos certos estilos e compositores que também davam ouvidos à voz falada. Na música vocal renascentista, por exemplo, essa identificação também era procurada pelos artistas. É o que assinala Lynn Liptak Budd, em Musical Attitudes in the Renaissance (1976):

o cantor deveria manifestar envolvimento com a mensagem da canção. A música era concebida como uma manifestação direta da situação: a canção e as palavras formavam a unidade da mensagem. Deveriam retratar as convicções dos sentimentos interiores do homem (Apud ZWILLING, 2007:84)

É claro que, no vasto repertório de música cantada, esse "envolvimento com a mensagem" pode configurar diferentes formas artísticas. O compositor pode até mesmo se expressar por meio de recursos musicais que se distanciam da fala. De certo modo, na música erudita também encontramos ambos os procedimentos. Nas óperas, por exemplo, há o recitativo (mais ligado à fala) e a ária (mais ligada à música) ${ }^{6}$. No cantochão ou canto gregoriano encontramos as melodias silábicas (mais entoativas) e as melodias melismáticas (com mais ornamentações musicais) ${ }^{7}$. Nas composições polifônicas do período chamado Ars Antiqua (séculos XII e XIII) há igualmente as

\footnotetext{
${ }^{6}$ Tanto que, ao propor uma reforma da ópera no século XVIII, Gluck (1714-1787), preocupado com a simplicidade e a verdade dramática na musicalização do texto, dirigiu suas principais críticas aos exibicionismos vazios do bel canto presentes nas árias de seu tempo.

${ }^{7}$ As ornamentações como os longos melismas sobre uma única sílaba por vezes átona fazem com que o aspecto sonoro salte à frente da fala. $\mathrm{O}$ acento melódico é então mais importante do que o acento das palavras. É quando sentimos mais a música do que o texto.
} 
inclinações mais orais do conductus e as inclinações mais vocais do moteto ${ }^{8}$. Enfim, mesmo na música de concerto europeia há momentos em que a entoação se percebe de maneira um pouco mais acentuada. Na canção popular, no entanto, o envolvimento com a mensagem por meio da proximidade do canto com a fala é muito mais nítida, pois a melodia entoativa é um dos principais recursos composicionais para o cancionista. Além disso, notamos que essa característica é o que torna esse gênero artístico uma manifestação francamente popular. Se não há nada mais natural e cotidiano do que a prática da língua oral, a canção, ao tomá-la para si, também se torna mais natural e cotidiana. Sob esse ponto de vista, ela é cultivada com maior facilidade, sobretudo em países como o Brasil onde a tradição cultural é mais oral do que escrita. É o que destaca Tatit, quando examina a intersemioticidade entre a linguagem da canção e a linguagem verbal.

\footnotetext{
Essa intersemioticidade garante, em última instância, o estatuto popular da canção. De fato, em virtude desse lastro entoativo e linguístico, cuja integração na fala do dia-a-dia todos estão aptos a fazer e a reconhecer, a canção apresenta uma tendência ao popular que justifica, de um lado, sua produção intuitiva (não alfabetizada do ponto de vista musical) e, de outro, sua enorme penetração e eficácia nos meios de comunicação. (TATIT, 2007:158)
}

A questão entoativa, além de evidenciar o "estatuto popular da canção", também nos permite diferenciar os procedimentos observados na música instrumental dos processos criativos da música cantada. Afinal, a preocupação do cancionista não é a mesma do músico. Geralmente, o compositor de música instrumental que se dedica à criação de canções não se interessa por uma relação mais íntima com a fala, pois a entoação pode prejudicar a estabilização melódica (normalmente o alvo de seu fazer artístico). Assim, em grande parte da produção vocal erudita o foco se encontra principalmente no aspecto sonoro: na construção melódica, nas relações entre a harmonia e as notas da melodia e na instrumentação ${ }^{9}$. É claro que essa construção musical pode levar em conta o sentido do texto poético, o "envolvimento com a mensagem". Contudo, raramente explora a fala de maneira mais efetiva, pois isso poderia interferir no acabamento musical da obra. De maneira oposta, para o cancionista

\footnotetext{
${ }^{8} \mathrm{O}$ moteto, com suas combinações muito heterogêneas e com sua maior experimentação de texturas polifônicas, não favorece a inteligibilidade do texto. Nesse sentido, a proibição dos motetos politextuais pelo Concílio de Trento (1545-1563), contrário a essa polifonia pela sua ininteligibilidade em relação às palavras bíblicas, representa uma espécie de reestabelecimento do equilíbrio, pois o moteto pendia demasiadamente para o lado da forma musical.

${ }^{9}$ Refiro-me principalmente à música vocal ligada à tonalidade.
} 
a ligação com a entoação é de fundamental importância. É o seu principal material criativo, mesmo que faça uso de recursos musicais comparáveis aos do compositor erudito $^{10}$.

Para o cancionista, ao contrário, a influência das leis entoativas que regem o discurso coloquial é um processo desejável, pois garante ao ouvinte uma rápida, ou até automática, conversão intersemiótica, do sistema da canção para o sistema da língua natural. Mais do que isso, o cancionista geralmente adota - voluntária ou involuntariamente - a estratégia persuasiva de estabelecer equivalências entre os dois sistemas, para tornar mais fluente sua comunicação com o ouvinte. É o que chamamos de figurativização enunciativa (TATIT, 2007: 158)

A figurativização é talvez o processo mais importante dentro do estudo da canção proposto por Tatit. Ela é o contrapeso em relação aos dois outros procedimentos de adequação mais ligados à música: a tematização e a passionalização. Como vimos acima, consiste numa elaboração entoativa da melodia aproximando o canto da coloquialidade da língua oral, como se oferecesse ao ouvinte momentos reais de enunciação. Eis o porquê de sua denominação. Assim como na análise semiótica de uma obra literária a remissão à realidade concreta é apontada pela presença das chamadas "figuras" do mundo real, na canção, a melodia que se aproxima da fala, remetendo igualmente à realidade concreta, também sugere as suas "figuras".

Por meio desse recurso o cancionista garante a presença da voz que fala dentro da voz que canta, colaborando para o efeito de "presentificação de situação locutiva" (TATIT, 1986: 15). A ligação com as esferas do aqui e do agora é muito importante para o ouvinte de canção. Ele se envolve com algo que lhe soa verdadeiro, pois sente inconscientemente uma proximidade com a fala que ele mesmo pratica. Observemos então alguns exemplos em que a construção melódica da canção estabelece conexões com a entoação da fala.

Como assinala Tatit ${ }^{11}$, a enunciação na língua oral se dá por meio de três fases entoativas. Uma fase inicial de ascendência que geralmente introduz um determinado assunto a ser tratado na comunicação. Um segundo momento de declínio no qual

\footnotetext{
${ }^{10}$ Em relação à oposição entre o trabalho do compositor-músico e do cancionista, é preciso destacar a diferença dos processos artísticos e das linguagens utilizadas. Ambos trabalham o texto verbal de forma específica, atingindo resultados estéticos diferentes, pois empregam técnicas distintas. Ao tratar o texto linguístico de forma não entoativa, priorizando aspectos puramente sonoros, o compositor-músico atinge espaços de expressividade que não costumam motivar o cancionista.

11 TATIT, 2002: 258-259
} 
podemos encontrar a opinião do enunciador ou o objetivo principal da comunicação. E, finalmente, a terceira e mais importante fase: o tonema, que pode sustentar o significado elaborado anteriormente ou modificá-lo radicalmente. É no tonema, ou seja, na inflexão presente na terminação da curva entoativa, que se observa a maior concentração de tensividade. É nele que se manifestam as articulações entoativas mais elementares: ascendência, descendência e suspensão melódica. A ascendência entoativa, como algo que exige uma complementação, tem na proposição interrogativa seu modelo mais explícito. Na canção, a linha melódica pode simular essa "figura" da fala para expressar o conteúdo de uma letra que pergunta.

Essa ladeira

Que ladeira é essa?

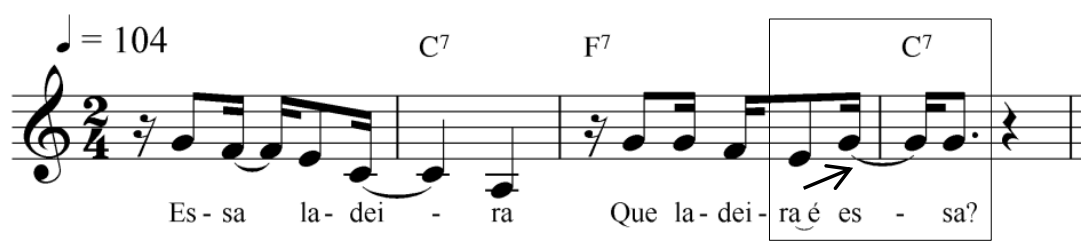

Figura 1.1-1: Ladeira da Preguiça (Gilberto Gil) [Faixa 1] ${ }^{12}$

No exemplo acima, o sentido interrogativo da melodia se manifesta pela sutil presença de um único intervalo ascendente de $3 \mathrm{~m}$ (Mi - Sol) com a posterior manutenção da nota aguda na segunda sílaba da palavra "essa". É um artifício para enfatizar a necessidade da complementação que virá na frase seguinte: “essa é a ladeira da preguiça". Pergunta e resposta. É claro, há muitas maneiras de se construir uma frase melódica de interrogação. Em Beatriz de Chico Buarque e Edu Lobo, por exemplo, o eu-lírico da letra da canção tece indagações que se refletem na melodia a partir de uma ascendência de toda a frase musical e não apenas dos últimos segmentos como vimos na passagem acima de Gilberto Gil.

Olha

Será que ela é moça?

Será que ela é triste?

Será que é o contrário?

Será que é pintura?

${ }^{12} \mathrm{CD}$ em anexo (página 137). 


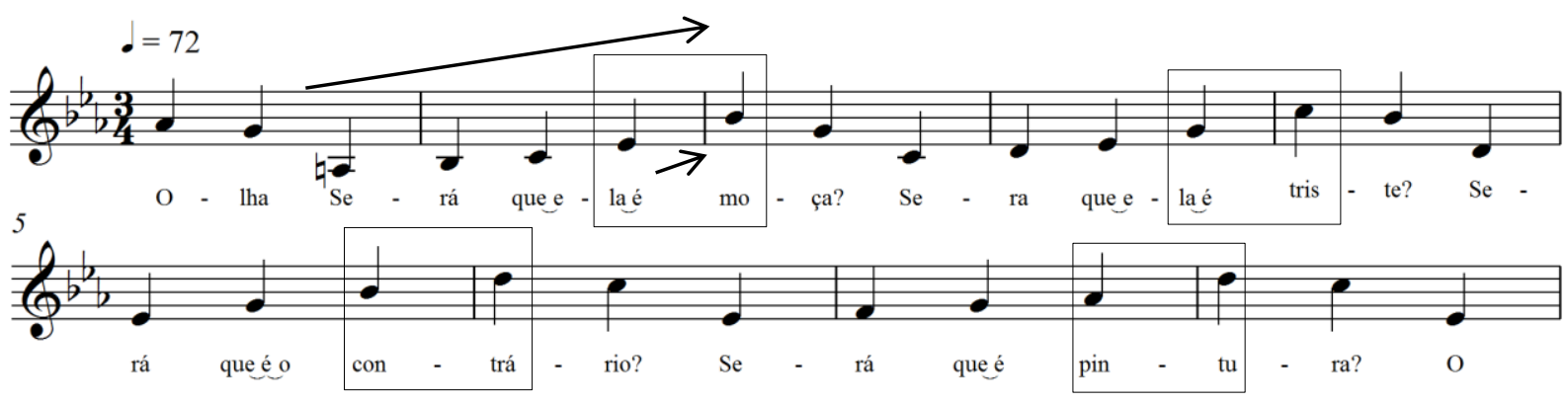

Figura 1.1-2: Beatriz (Edu Lobo/Chico Buarque) [Faixa 2]

Aqui, cada uma das frases interrogativas faz o percurso ascendente completo, nota a nota, rumo à altura mais aguda que recai sobre a sílaba tônica de suas palavras principais: "moça”, “triste”, “contrário" e "pintura”. É interessante a comparação entre os dois exemplos. A canção de Gilberto Gil, sem dúvida, apresenta uma força entoativa mais acentuada, com a melodia claramente submetida à fala. Em Beatriz, há maior presença da forma musical delineando o contorno melódico. Como é sabido, Chico Buarque compôs a letra dessa canção posteriormente à criação da música por Edu Lobo (cancionista que, assim como Tom Jobim, apresenta um interesse marcadamente musical). O letrista, de forma consciente ou inconsciente deve ter notado que nas elevações dos segmentos melódicos caberiam naturalmente frases linguísticas interrogativas. Desse modo, em ambos os exemplos, ainda que haja diferentes interesses estéticos, percebemos uma base entoativa fundamental (nesse caso, a ascendência) que possibilita a relação eficaz com o conteúdo de interrogação.

A articulação entoativa do tonema descendente, por outro lado, gera o sentido de "finalização" ou "terminatividade", ${ }^{13}$ como uma frase que não necessita de qualquer espécie de complementação, não aceita nenhum comentário ou dúvida. É o que observamos, por exemplo, no trecho final da canção Diferentemente de Caetano Veloso.

E, no entanto, diferentemente de Osama e Condoleezza

Eu não acredito em Deus

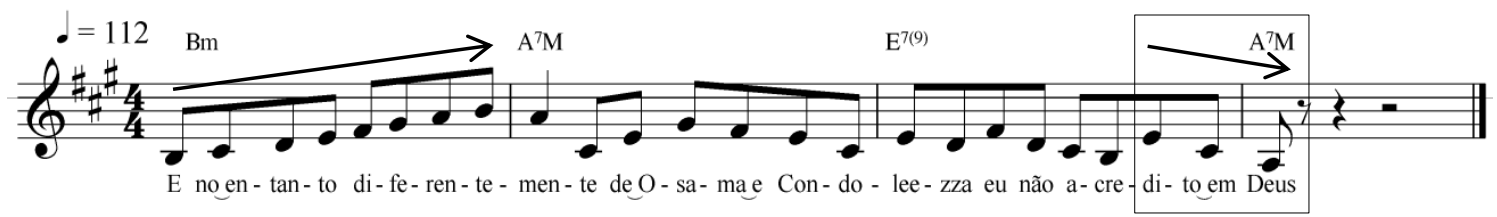

Figura 1.1-3: Diferentemente (Caetano Veloso) [Faixa 3]

13 TATIT, 2007: 170 
O caráter conclusivo da letra é reforçado pela descendência melódica final (Do\# - Lá), assim como ouvimos, numa situação habitual de fala, uma frase asseverativa. Há também elementos puramente musicais que colaboram para o efeito contundente da afirmação "eu não acredito em Deus”. Primeiramente, a cadência harmônica dominantetônica que reforça em muito o sentido de terminação: o acorde de Mi maior com sétima menor (E7(9)) antecedendo o acorde de Lá maior com sétima maior (A7M). Além disso, as três últimas notas do canto (Mi - Do\# - La) formam o arpejo do acorde de Lá maior, o que enfatiza ainda mais esse mesmo sentido tonal. Um perfil melódico como esse, na música ou na fala, é sempre conclusivo. Tem o sentido de relaxamento em relação às tensões acumuladas até então pelo cantor/falante que mantinham acesa a atenção do ouvinte para o que vinha sendo cantado/contado. Assim, observamos que a asseveração se faz por meio de uma descendência final antecedida por uma ascendência, obedecendo ao princípio da tensão-distensão. O segmento inicial (ascendente) apresenta a tensão necessária para despertar no ouvinte o interesse pelo assunto e por sua posterior conclusão distensiva. Desse modo, fato também observado na canção de Caetano Veloso, a afirmação final descendente é valorizada pela tensão do segmento ascendente anterior (primeiro compasso da figura acima).

(...) o princípio universal é a oposição dessas inflexões (descendência e ascendência). O rendimento da descendência indicando finalização é tanto maior quanto mais acentuada for a ascendência anterior. (TATIT, 2007:172)

Outra articulação tensiva apontada por Tatit é a suspensão melódica. O tonema não é ascendente nem descendente. $\mathrm{O}$ segmento final da melodia mantém notas de mesma altura, gerando o sentido de algo que não foi concluído, o que faz o ouvinte aguardar a continuidade do discurso.

No palco, na praça, no circo, num banco de jardim

Correndo no escuro, pichado no Muro

Você vai saber de mim 


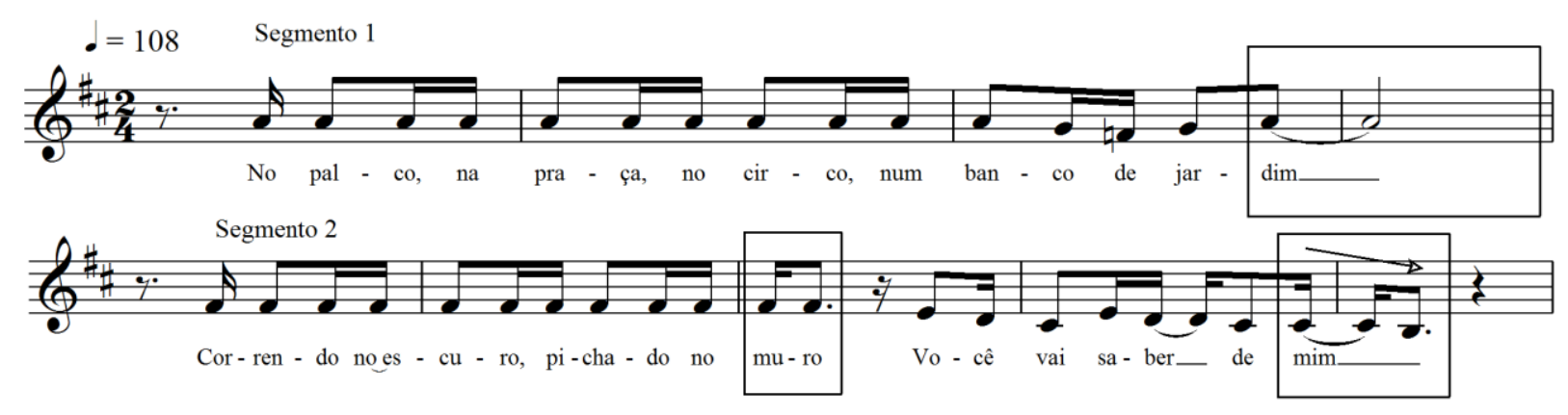

Figura 1.1-4: Mambembe (Chico Buarque) [Faixa 4]

Esse fragmento da canção de Chico Buarque traz elementos interessantes para o estudo desse tipo de tonema. Os dois primeiros segmentos apresentam um caráter suspensivo e preparam a conclusão do terceiro segmento. Esse efeito de suspensão, no entanto, se dá em graus diferenciados de intensidade (o segundo mais intenso que o primeiro). A frase inicial (segmento 1) reitera a nota Lá e termina com a mesma altura, após uma rápida passagem pelos graus imediatamente inferiores (Sol-Fá-Sol), produzindo o sentido de algo inacabado. No entanto, a frase seguinte (segmento 2) acentua ainda mais essa suspensão e necessidade de conclusão, pois além de manter estritamente a mesma nota (Fá \#), apresenta uma quebra em relação ao padrão rítmico da frase anterior (que ocupava os quatro compassos iniciais). O menor comprimento do segundo segmento (apenas dois compassos e meio) causa uma espécie de interrupção desse padrão aumentando ainda mais a necessidade de um relaxamento conclusivo. Observamos então a ausência de ascendência ou descendência nas duas primeiras frases. A primeira mantendo-se sobre a nota Lá e a segunda sobre a nota Fá\#. Apenas quando a melodia desce para o grave (segmento 3) sentimos uma terminação, tanto no plano musical quanto no conteúdo linguístico.

Como podemos notar, as fases entoativas de ascendência e descendência presentes no processo de enunciação da língua oral são muito importantes para o sentido da melodia-texto da canção. Talvez para grande parte da música cantada. Podemos, por exemplo, relacioná-las facilmente com certas configurações de melodias do cantochão, nos primórdios da história da música europeia: a configuração da frase na forma de um arco, que começa no grave, eleva-se e desce para a finalização.

Além da questão das fases entoativas e das diferentes articulações dos tonemas, encontramos na canção popular outros fenômenos ligados ao pensamento entoativo da melodia. Como assinala Tatit, na língua oral, a melodia da fala está absolutamente submetida ao texto a ser transmitido. 
Em nossa comunicação cotidiana, a entoação está totalmente a serviço da mensagem linguística. Jamais deixamos de dizer algo por não caber numa medida prefixada pela melodia. Temos a segurança, plenamente subentendida, de que a entoação possui elasticidade infinita, adaptável a qualquer texto (TATIT, 2002:119)

Essa característica, ainda que óbvia para quem fala, é crucial para a análise de várias obras do cancioneiro popular. A ausência de um projeto sonoro (fato comum na linguagem cotidiana) também pode constituir um importante recurso para o compositor de canções que estabiliza a melodia de maneira menos rígida para poder abarcar uma letra que aumenta ou diminui conforme a necessidade do que precisa ser dito. Trata-se da composição de canções com menor controle musical do texto, na qual uma melodia "elástica" está totalmente a serviço da entoação das palavras. O ponto extremo desse procedimento composicional fortemente figurativo é, segundo Tatit, Jorge Ben Jor. Podemos examinar uma conhecida canção do compositor, dessa vez em parceria com Toquinho:

\section{[PARTE A1]}

Lá fora está chovendo

Mas assim mesmo eu vou correndo

Só prá ver o meu amor

\section{[PARTE A2]}

Pois ela vem toda de branco

Toda molhada linda e despenteada,

Que maravilha, que coisa linda que é o meu amor

\section{[PARTE B]}

Por entre bancários, jatomóveis, ruas e avenidas

Milhões de buzinas tocando minha harmonia sem cessar

E ela vem chegando de branco, meiga, pura, linda e muito tímida

Com a chuva molhando o seu corpo lindo que eu vou abraçar

E a gente no meio da rua, do mundo, no meio da chuva

A girar, que maravilha

A girar, que maravilha

A girar 


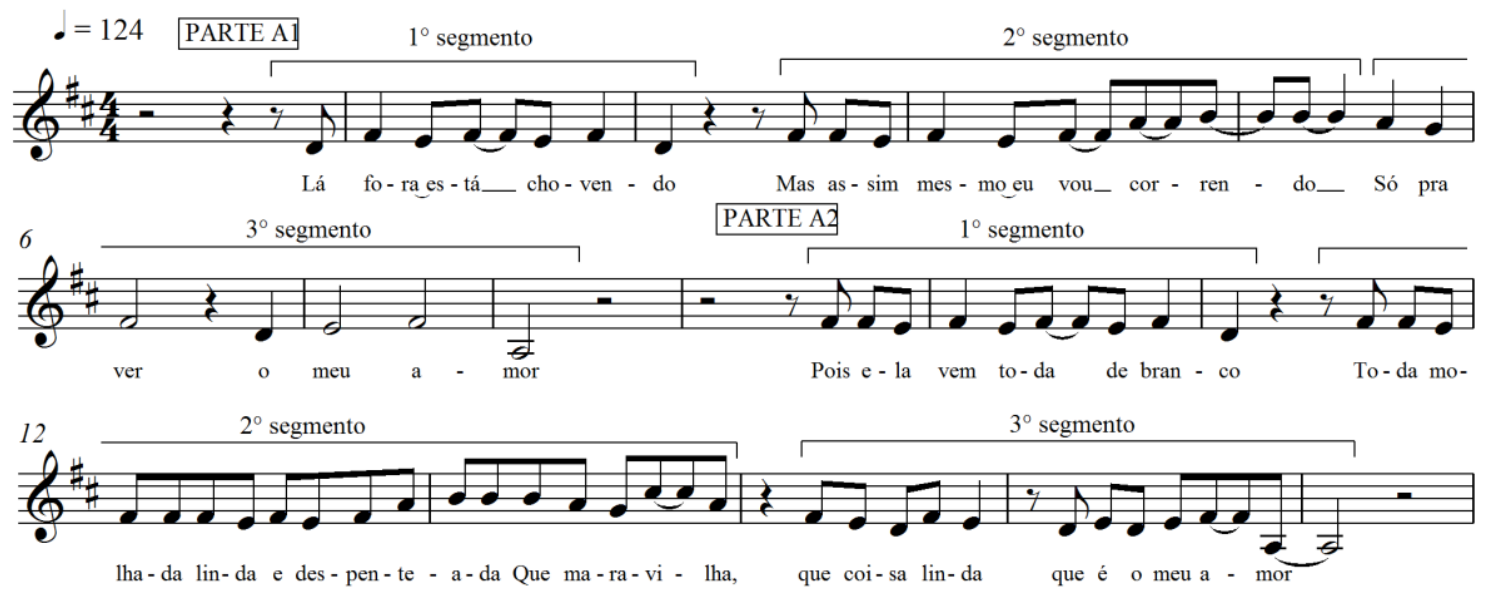

Figura 1.1-5: Que maravilha (Jorge Ben Jor/Toquinho) [Faixa 5]

Nesse exemplo, quando comparamos as duas primeiras estrofes da canção, podemos identificar o mecanismo apontado por Tatit em relação à maleabilidade da melodia em favor do texto. Na figura acima, como é comum constatarmos não somente na canção popular, mas também no repertório vocal erudito, observamos uma construção melódico-harmônica (parte A1, compassos 1 a 8) que é repetida com uma nova letra (parte A2, compassos 9 a 16) antes da passagem para a parte B. Entretanto, o uso desse procedimento de repetição em Jorge Ben Jor raramente se faz de maneira estrita, pois essa nova letra traz consigo outras exigências entoativas que são priorizadas pelo compositor em detrimento da rigorosa repetição do padrão melódico anterior. Aqui, é mais importante dar vazão ao texto linguístico do que reiterar o que foi estabelecido pelo pensamento musical. É a liberdade entoativa da fala que permite as alterações do padrão musical.

Para auxiliar essa breve análise, as duas primeiras estrofes (partes A1 e A2) foram divididas cada uma em três segmentos $^{14}$. Se compararmos cada um dos segmentos da parte A1 com o seu correspondente da parte A2, veremos que na repetição o compositor subverteu o padrão melódico inicial aumentando o número de figuras rítmicas e palavras para o mesmo espaço de tempo. Em relação ao primeiro segmento, na parte A2, o levare é expandido apresentando duas notas a mais: o vocábulo "lá" dá lugar a "pois ela". Assim, três sílabas passam a ocupar o espaço onde havia apenas uma. $\mathrm{O}$ restante da frase, no entanto, mantém-se rigorosamente igual. O segundo segmento apresenta alterações muito mais significativas. Se o observarmos apenas até o primeiro

\footnotetext{
${ }^{14}$ Outras formas de divisão e estabelecimento dos limites entre cada segmento são possíveis. O segundo segmento da segunda estrofe, por exemplo, poderia se estender somente até o primeiro tempo do compasso 13, deixando a frase "que maravilha" para o segmento seguinte.
} 
tempo do compasso 5, para a parte A1, e do compasso 13, para a parte $\mathrm{A} 2$, veremos que as oito sílabas do verso "Mas assim mesmo eu vou correndo" tornam-se doze em "Toda molhada linda e despenteada" 15 . E poderíamos até mesmo considerar que o compositor, na repetição, ainda continua o segmento ascendente com a frase "que maravilha". O mesmo processo se observa para o terceiro segmento, ritmicamente adensado na repetição. Enfim, podemos constatar que a construção melódica dessa canção obedece mais a procedimentos de entoação do que de música, como se não houvesse um "controle musical do texto". ${ }^{16}$ Se esse controle fosse preponderante, o cancionista certamente manteria na parte A2 o mesmo padrão rítmico-melódico da parte A1, adequando a letra para não modificar a música.

O caso específico dessa canção é interessante pelo fato de ter sido composta por dois autores que, em razão das suas características artísticas próprias, a interpretam com versões significativamente distintas. Toco nesse ponto, pois a diferença entre elas pode nos indicar a preocupação mais entoativa em uma e a preocupação mais musical em outra, isto é, graus diferentes de figurativização. Vejamos então a versão geralmente cantada por Toquinho [Faixa 6], em contraposição à versão de Jorge Ben Jor já comentada acima.

[PARTE A1]

Lá fora está chovendo

Mas assim mesmo eu vou correndo

Só prá ver o meu amor

[PARTE A2]

Ela vem toda de branco

Toda molhada e despenteada,

Que maravilha, que coisa linda que é o meu amor

[PARTE B]

Por entre bancários, automóveis, ruas e avenidas

Milhões de buzinas tocando sem cessar

Ela vem chegando de branco, meiga e muito tímida

Com a chuva molhando o seu corpo que eu vou abraçar

E a gente no meio da rua, do mundo, no meio da chuva

\footnotetext{
${ }^{15} \mathrm{Na}$ escansão dos versos de um poema, isto é, em sua análise métrica, a contagem das sílabas se faz até a última sílaba tônica de cada verso, desprezando-se as sílabas átonas finais.

${ }^{16}$ TATIT, 2002:212
} 
A girar, que maravilha

A girar, que maravilha

A girar

Interessa-nos aqui observar as diferenças interpretativas da parte A2 e da parte B. Comparando as duas letras, notamos que a versão de Toquinho é sensivelmente mais enxuta, com a eliminação de vários vocábulos presentes na interpretação de Ben Jor. As palavras "pois" e "linda" (parte A2) e "minha harmonia", "pura", "linda" e "lindo" (parte B) são suprimidas para que a melodia fique mais regular, livre das "impurezas" da fala. Para Ben Jor, no entanto, não há problema algum nessa aproximação com a irregularidade da língua oral. Enfim, a própria redundância dos termos empregados por ele e excluídos por Toquinho não deixa de estabelecer igualmente certa relação com a fala, que geralmente é redundante para enfatizar determinada ideia que o enunciador deseja transmitir.

Além da questão das fases entoativas, das articulações do tonema e dessa melodia "elástica", o gesto figurativo pode se fazer presente na canção popular de muitas outras maneiras. Por vezes de forma muito sutil, mas fundamental para a construção do sentido da melodia com a letra.

Eu não acho mais graça nenhuma nesse ruído constante

Que fazem as falas das pessoas falando

Cochichando e reclamando

O que eles querem mesmo é reclamar

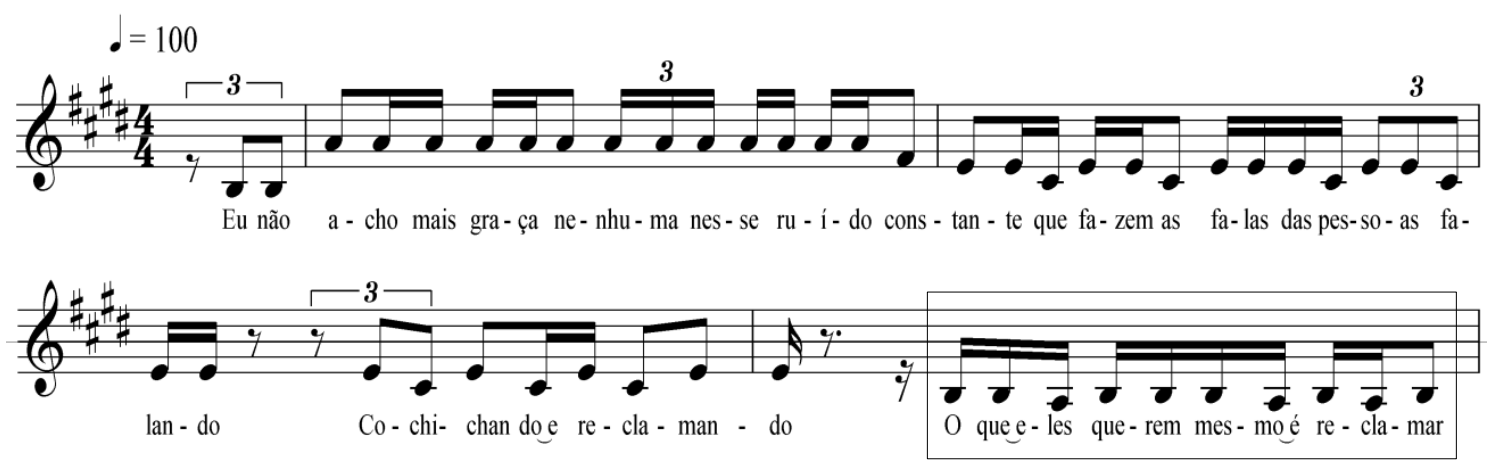

Figura 1.1-6: E estamos conversados (Arnaldo Antunes/Paulo Tatit) [Faixa 7]

Nesse exemplo, queremos chamar a atenção apenas para o último compasso do fragmento. A relação dessa canção com a fala também pode ser observada por certa irregularidade das figuras rítmicas, além da disposição clara das articulações entoativas 
comentadas acima: uma asseveração ("Eu não acho mais graça nenhuma nesse ruído constante") e duas suspensões ("que fazem as falas das pessoas falando" e "cochichando e reclamando"). ${ }^{17}$ Contudo, é no último compasso que um gesto de fala mais sutil nos é apresentado. A frase "O que eles querem mesmo é reclamar", disposta em região mais grave, soa não apenas como afirmação comum, mas também como uma espécie de conclusão de um turno conversacional, que retoma e enfatiza o assunto já tratado, procedimento que se repetirá no decorrer da música: o enunciador está conversando com seu interlocutor e nesse ponto parece realizar um comentário à parte relacionado ao que já havia dito. Como uma breve conclusão na qual expõe sua opinião, antes de dar prosseguimento à conversa. Assim, o sentido dessa passagem melódica depende muito da sua relação com esse gesto figurativo. Explicá-la apenas a partir de elementos musicais resultaria, portanto, numa análise improdutiva ou no mínimo incompleta.

Por fim, conforme aponta Tatit, ${ }^{18}$ o procedimento figurativo de compatibilização entre melodia e letra, mesmo que não seja prioritário em canções de apelo mais musical do que entoativo, estará sempre presente, ainda que apenas timidamente, nas inflexões dos tonemas ou nos pequenos gestos de fala. Há sempre um grau mínimo de figurativização necessário para que a melodia se relacione com o conteúdo da letra de maneira convincente.

\footnotetext{
${ }^{17}$ Poderíamos considerar esse trecho dos compassos 2 e 3 como uma única suspensão dividida em dois segmentos, já que ambas as frases reiteram e mantém a nota Mi na terminação.

${ }^{18}$ TATIT, 2002:119
} 


\subsection{A figurativização no rap}

A presença da fala no rap é algo extremamente evidente para o ouvinte, sendo a principal característica do gênero. A figurativização é tão marcante que é praticamente impossível encontrarmos uma canção que não possua, além do usual canto falado mais estabilizado ritmicamente, inserções de falas diretas sem qualquer tipo de musicalização. O maior grupo de rap brasileiro, Racionais MC's, possui ao todo cinco discos de estúdio: Holocausto urbano (1990), Escolha o seu caminho (1992), Raio X Brasil (1993), Sobrevivendo no inferno (1997) e Nada como um dia após o outro (2002), totalizando cinquenta e uma faixas gravadas. De todo esse repertório há somente uma única obra em que não encontramos nenhum trecho de fala direta, aliás, a única faixa instrumental de toda a carreira do grupo ${ }^{19}$. Curiosamente, nem o título da canção contém palavras. Trata-se da sexta faixa do álbum Sobrevivendo no inferno, cujo nome é um sinal gráfico de pontuação, a sequência de três pontos das reticências. Nada mais apropriado para suspender ou omitir algo que poderia ter sido dito, mas que não se realizou. Até mesmo aqui, de alguma forma, a fala (omitida) está presente. Enfim, notamos que em praticamente todas as canções do grupo há trechos falados sem qualquer estabilização rítmica. São diálogos entre os rappers, conversas telefônicas e sons de vozes simulando cenas de violência ou ilustrando determinadas situações. Nesses momentos, o uso da fala é radical. Por exemplo, 12 de outubro ${ }^{20}$ é uma faixa composta unicamente pela voz falada de Mano Brown. A fala em estado bruto. Observamos a ocorrência de hesitações, redundâncias e reformulações típicas da língua oral. No fragmento transcrito abaixo [Faixa 8], o rapper relata a ocasião em que encontrou com crianças de uma comunidade pobre e indagou sobre seus estudos ${ }^{21}$.

E aí mano, e aí? Tá estudando? Tal...

Aí o moleque falou assim:

- Esse aqui hoje xingou a mãe dele

Aí eu falei assim:

- Por que você xingou sua mãe?

- Ah, porque...

Não! Nem foi isso... Ele falou assim... Eu falei...

${ }^{19}$ Ver no Anexo, com maior detalhamento, os exemplos da presença desse tipo de ocorrência nas canções dos cinco álbuns listados acima.

${ }^{20}$ In: Nada como um dia após o outro dia (2002)

${ }^{21}$ Destacamos os trechos de 1'05'' a 1'15', e de 2'22'" a 2'29'. 
Vocês ganharam presente? Eu perguntei. Não foi não Neto?

Vocês ganharam presente? Ele falou:

- Eu ganhei foi tapa na cara hoje.

Importante assinalar que o fundo musical é ritmicamente instável. É composto por um violão que tece frases musicais sem padrões rítmicos marcados, com pulso indefinido ou variável e sem nenhuma preocupação em formar uma base regular para o rapper. Essa característica da base também favorece a falta de musicalização do texto. É interessante destacar que todos os "erros" de fala observados acima não foram eliminados do fonograma. Isto é, a instabilidade entoativa não incomoda de modo algum esses artistas. Quando comparamos o rap com gêneros mais próximos estilisticamente, como o samba de breque, notamos que essas ocorrências dificilmente se dão fora do universo do hip hop. Tanto o $\mathrm{MC}^{22}$ quanto o sambista trabalham a melodia de maneira figurativa e criam partes faladas que se intercalam às partes cantadas. Ou seja, os dois gêneros estão tão próximos da língua oral que permitem de forma muito natural e até mesmo imperceptível a inserção de um trecho falado, às vezes sem qualquer nível de musicalização. No entanto, em um samba de breque, a fala geralmente aparece de maneira mais estabilizada e muitas vezes se transforma em uma espécie de bordão que provavelmente será repetido por todos os intérpretes que cantarem a mesma obra. Diferentemente do exemplo acima de Mano Brown, que dificilmente será repetido por outro intérprete. Se isso ocorrer, provavelmente o estará imitando e não reinterpretando a faixa.

Além desses trechos com presença direta da fala, há momentos em que o rapper subverte a divisão rítmica que vinha realizando e sai da pulsação, como se o ímpeto de falar certa frase fosse mais forte do que a vontade de se manter na batida da base. É a figurativização subvertendo a regularidade musical. Em Homem na estrada [Faixa 9], Mano Brown abandona a pulsação da base e canta alguns versos de maneira independente em relação à divisão métrica com a qual entoava a letra ${ }^{23}$.

Vinte anos de idade alcançou os primeiros lugares,

Superstar do Notícias Populares

\footnotetext{
${ }^{22}$ MC é abreviação de "mestre de cerimônia”, o responsável por animar o público nas festas que deram origem ao gênero rap na década de 1970.

${ }^{23} \mathrm{O}$ trecho destacado ocorre a partir de 4'49',
} 
Além do mais, nesse trecho, tanto para enfatizar a frase do MC, quanto para não haver um embate indesejado entre a pulsação da canção e a divisão mais acelerada dos versos acima, o fundo musical é suprimido pelo DJ. Em Estilo Cachorro [Faixa 10], Ice Blue também realiza a letra com maior instabilidade rítmica, deixando de lado a tematização ${ }^{24}$.

Tenho uma agenda com dezenas de telefone

Uma lista de características e os nome

Em V.L parte 2 [Faixa 11], Brown enfatiza ainda mais a figurativização quando entoa os versos seguintes. Transmitindo raiva em sua interpretação, o rapper abandona a divisão rítmica da base para emitir a palavra "cu" fora da subdivisão esperada ${ }^{25}$.

Preto e dinheiro são palavras rivais, é?

Então mostra pra esses cu como é que faz

Outro procedimento comum no rap é a inserção de conversas telefônicas. Em Jesus chorou [Faixa 12] ${ }^{26}$, enquanto o rapper canta, ouvimos tocar um telefone. Em seguida ele atende e inicia-se um diálogo com um interlocutor do outro lado da linha (cuja voz é também de Mano Brown). Em Fone (intro) [Faixa 13] ${ }^{27}$ observamos a mesma situação. São momentos significativos em que a regularidade rítmica é deixada de lado em favor da fala. Crime vai e vem [Faixa 14] e V.L parte $2^{28}$ também são bons exemplos desse tipo de construção. Na primeira, Ice Blue predominantemente entoa a letra com ritmo regular. No entanto, quando canta a expressão "Aê, truta", sentimos claramente a instabilidade rítmica de sua emissão. Nesse momento, assim como observamos em Homem na estrada, parte da base rítmica é também suprimida pelo DJ.

Pra cadeia não quero não volto nunca mais Aê truta, se for pra ser eu quero é mais

\footnotetext{
${ }^{24} \mathrm{O}$ trecho destacado ocorre de 2 ' 45 '" a 2'51',

${ }^{25}$ O trecho destacado ocorre de 3'56', a 4'02',

${ }^{26}$ In: Nada como um dia após o outro dia (ri depois) (2002)

${ }^{27}$ In: Nada como um dia após o outro dia (ri depois) (2002)

${ }^{28}$ In: Nada como um dia após o outro dia (ri depois) (2002)
} 
Em V.L parte 2 também notamos algo interessante ${ }^{29}$. Ao final dessa canção, há uma fala de Mano Brown que se apresenta apenas parcialmente musicalizada. Ainda verificamos a presença de rimas, mas o texto não é entoado com uma configuração rítmica regular, como observamos no restante da obra. Nesse trecho [Faixa 15], grande parte das sílabas não é pronunciada sincronicamente em relação aos ataques rítmicos da base. Assim, a tematização é minimizada tendo em vista essa maior instabilidade musical.

Porque o guerreiro de fé nunca gela

Não agrada o injusto e não amarela

O rei dos reis foi traído e sangrou nessa terra

Mas morrer como um homem é o prêmio da guerra

Mais ó, conforme for, se precisar afogar no próprio sangue

Assim será

Nosso espírito é imortal, sangue do meu sangue

Entre o corte da espada e o perfume da rosa

Sem menção honrosa, sem massagem

A vida é loka nego e nela eu tô de passagem

À Dimas, o primeiro

Saúde guerreiro

Dimas

Observamos então que a figurativização no rap não se restringe ao canto falado. Há também a exploração direta da fala nas canções e muitas vezes, como é caso da canção 12 de outubro, certos trechos são executados com tamanha espontaneidade que trazem marcas conversacionais típicas da língua oral. Perguntamo-nos então o porquê da presença desses textos com pouquíssimo nível de musicalização. Como veremos mais adiante, a comunicação da mensagem é tão importante para o rapper (dar o recado é fundamental) que somente a fala ritmada parece não ser suficiente. É preciso dizer de forma ainda mais direta. Fato curioso para um gênero que já explora fortemente a fala. Nesses trechos essa exploração é ainda mais radical.

Mas há uma nítida diferença, para quem faz e para quem escuta rap, entre esses exemplos acima e a composição dos MC's propriamente dita. Mesmo que intuitivamente, o ouvinte sabe quando o rapper está cantando a letra e quando ele está

\footnotetext{
${ }^{29} \mathrm{O}$ trecho a que me refiro ocorre de 4'49', até o final da faixa.
} 
realizando falas sem qualquer tipo de musicalização. Por exemplo, percebemos uma diferença clara entre os fragmentos citados acima e os trechos abaixo:

Chame a ambulância

Alguém chame a ambulância

$$
\text { - }=84
$$

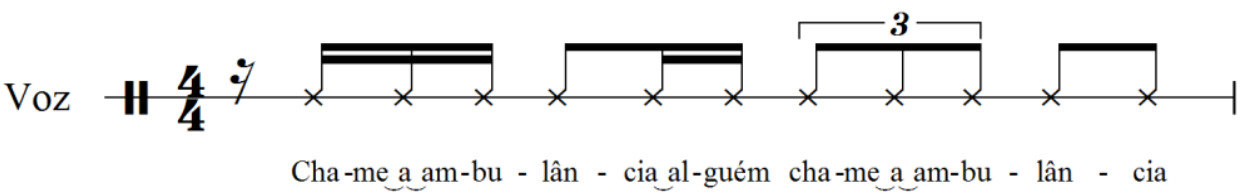

Figura 1.2-1: Voz de Ice Blue em Rapaz Comum (Racionais MC's) [Faixa 16]

Cuidado senhora,

Tome as rédeas da sua cria

$=84$

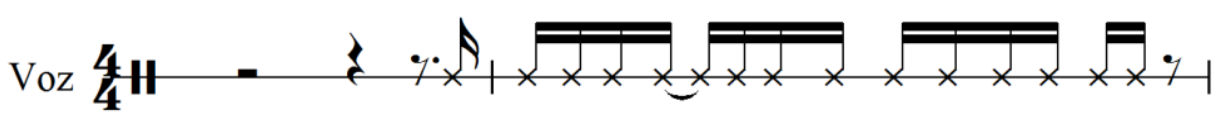

Cui - da -do se - nho - ra to-me as ré -deas da sua cri-a

Figura 1.2-2: Periferia é periferia (em qualquer lugar)... (Racionais MC's) [Faixa 17]

Nesses exemplos, não é o cantor principal quem entoa os versos. Em ambos, ouvimos a voz de outro indivíduo interagindo com o canto do MC. No rap, muitas vezes, esse tipo de ocorrência aparece na forma de uma fala direta, sem estabilização rítmica. Mas aqui, diferentemente, já temos algum nível de musicalização. Na figura 1.2-1, esse nível é tão mínimo que não sabemos ao certo se Ice Blue está cantando ou simplesmente falando a frase "chame a ambulância, alguém chame a ambulância!". Sentimos, porém, a entoação perfeita de um pedido de socorro, mas realizado com um padrão rítmico determinado, isto é, com um teor mínimo de musicalização. Destacamos a mesma situação em Periferia é periferia (em qualquer lugar)... na qual observamos uma maior preocupação com a estabilidade musical. A frase "cuidado senhora, tome as rédeas da sua cria" apresenta uma configuração rítmica regular e também estabelece uma rima com a última palavra do verso anterior entoado pelo cantor principal da faixa ("Herdeiro de mais alguma dona Maria"). Assim, constatamos que é parte do trabalho artístico dos MC's a possibilidade de optar por diferentes níveis de musicalização do texto, ora realizando uma fala mais explícita, ora uma fala mais ritmada. Desse modo, 
começamos a perceber as nuances da presença da figurativização no rap, pois há nele variados graus de presença da língua oral.

Nesse momento, é necessária uma observação mais detalhada sobre a constituição da melodia do rap, isto é, dos versos rimados e ritmados (que é o que primeiramente caracteriza a música do hip hop $)^{30}$. Veremos então o porquê da predominância da figurativização. Além disso, é importante refletirmos sobre um fato curioso que frequentemente ocorre na recepção desse tipo música, devido à força do processo figurativo: acostumado com o repertório das canções tonais, o ouvinte encontra no rap tanta instabilidade e relação com a fala, que muitas vezes não o considera nem mesmo um gênero musical. Vamos examinar essa questão com maior cuidado.

No rap predominantemente encontramos um texto verbal entoado com certa regularidade rítmica. A emissão das sílabas do texto cantado coincide com os ataques percussivos da base ou com subdivisões regulares dos pulsos que o arranjo sugere. Esse fato já significa um primeiro nível de musicalização, pois na língua oral raramente encontramos um ritmo regular.

Ao examinar grande parte da produção do rap brasileiro, pudemos constatar que todos apresentam praticamente o mesmo padrão rítmico. Predominantemente, encontramos uma subdivisão binária da pulsação. As sílabas da letra sempre subdividem o pulso em quatro partes, como na figura abaixo ${ }^{31}$. Notamos então que mesmo com a forte presença da língua oral, há elementos musicais fundamentais para a composição do rap. Caso contrário, qualquer discurso verbal poderia se tornar uma canção. No exemplo seguinte, percebemos claramente a existência de uma forma musical ordenadora que torna o rap diferente da fala coloquial.

Mano cavernoso um catador eficaz

Com dezesseis já foi manchete de jornal, rapaz

\footnotetext{
${ }^{30}$ Há até mesmo quem considere como rap apenas as partes cantadas com ritmo. Os trechos de fala, os samples inseridos pelos DJ's e os refrãos estabilizados muitas vezes não são considerados como rap propriamente dito. É uma discussão que faremos mais adiante.

31 Os padrões rítmicos ligados à tematização serão explicados de maneira mais detalhada no capítulo seguinte. Aqui interessa apenas constatar a subdivisão em semicolcheias com alguma variação de acentos (binários ou ternários) sugeridos diretamente pelos acentos das palavras da letra.
} 


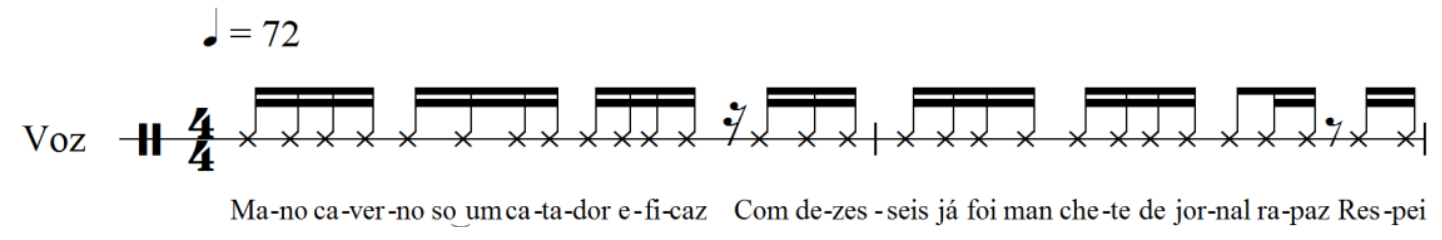

Figura 1.2-3: Rap é compromisso (Sabotage) [Faixa 18]

Além disso, é bastante comum a configuração rítmica da melodia da voz ser sutilmente alterada por meio de inflexões realizadas pelo $\mathrm{MC}$ a partir do acento tônico das palavras da letra. No exemplo abaixo, a subdivisão binária do pulso em quatro semicolcheias tem seu caráter modificado pelas acentuações do texto verbal enfatizadas pelo cantor. Os versos "para os manos daqui", "para os manos de lá" e "negro pra negro será” são cantados com acentuação ternária.

Para os manos daqui

Para os manos de lá

Se você se considera um negro pra negro será

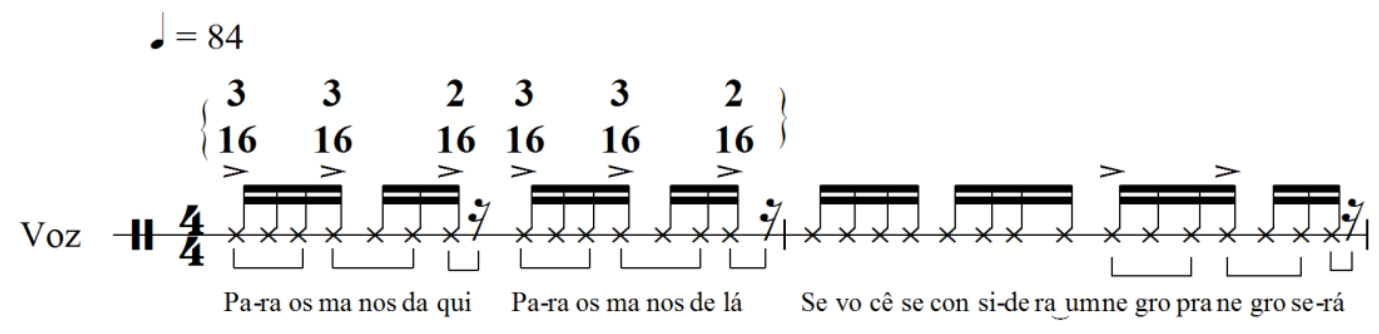

Figura 1.2-4: Voz ativa (versão rádio) (Racionais MC's) [Faixa 19]

Em Capítulo 4, versículo 3, constatamos a mesma configuração: a predominância das subdivisões em quatro partes e momentos específicos com variação de acento ternário.

Agora não oferece mais perigo

Viciado, doente, fudido, inofensivo

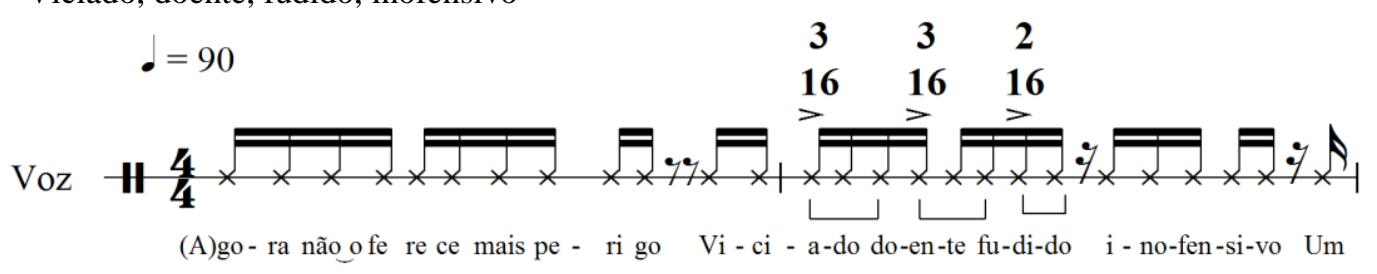

Figura 1.2-5: Capítulo 4, versículo 3 (Racionais MC's) [Faixa 20] 
Muitas vezes encontramos também a seguinte variação: ao invés da subdivisão regular em quatro semicolcheias verificamos a intercalação de figuras pontuadas e simples. Continuamos com quatro ataques por unidade de tempo. No entanto, as durações são variáveis, pois há a alternância de sílabas longas (L) e sílabas breves (B).

Me atire uma pedra que eu te atiro uma granada

Se tocar em minha face sua vida está selada

Portanto meu amigo pense bem no que fará
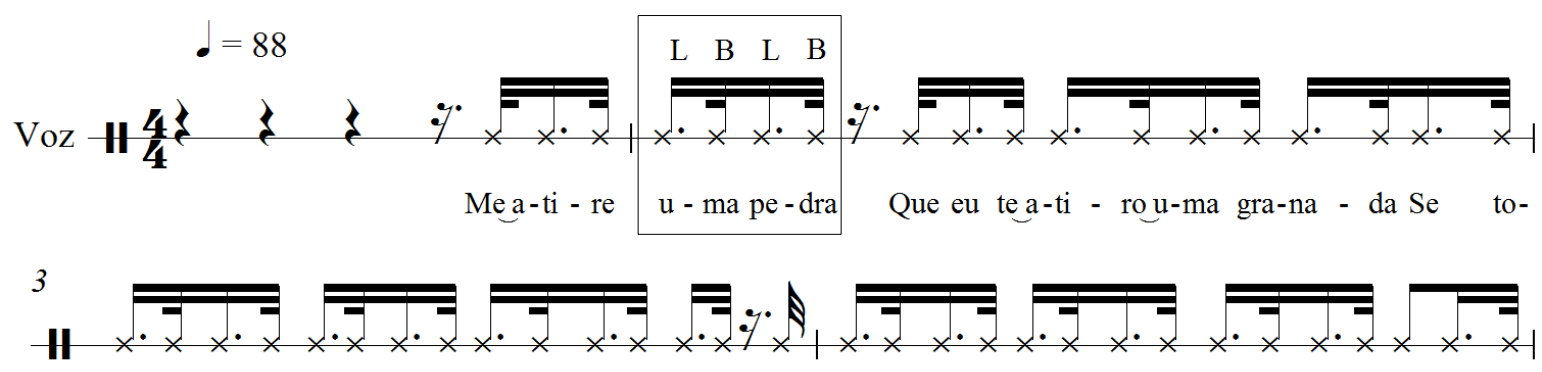

car em mi-nha fa-ce su - a vi-da es-tá dse-la-da Por - tan-to meu-a-mi-go pen-se bem no que fa-rá Pois não

Figura 1.2-6: Corpo fechado (Thaíde e DJ Hum) [Faixa 21]

Sou da favela

Tô aqui Sabotage

Tem certos lugar

Ligeiro criminalidade

Eu tô de pé, bum

Não arrisco o pescoço, é

Dá desgosto porque aqui não tem socorro

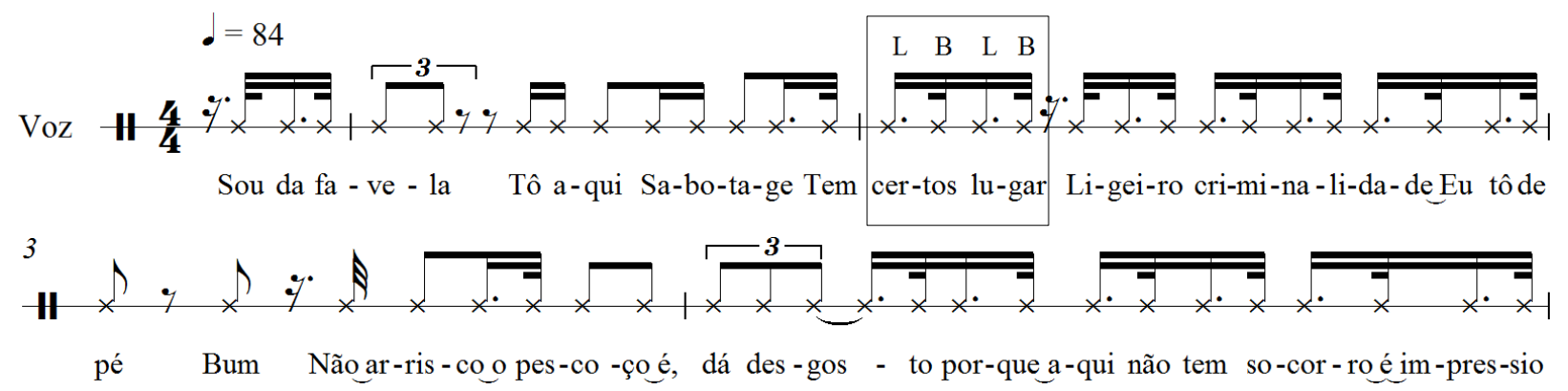

Figura 1.2-7: Respeito é pra quem tem (Sabotage) [Faixa 22]

Nos exemplos acima de Thaíde e Sabotage as sílabas que recaem sobre as notas pontuadas duram mais do que as que recaem sobre as notas simples. Geralmente, essas 
figuras pontuadas correspondem às sílabas tônicas dos vocábulos. Em Corpo fechado, por exemplo, notamos que apenas a palavra "uma" não é cantada com a nota pontuada recaindo sobre a sua sílaba tônica. Assim, constatamos que a duração alongada dessas notas representa, além de um balanço rítmico assumido pelo rapper, um apoio entoativo ligado à figurativização. Por um lado, a alternância entre as figuras longas e breves traz para a canção um interesse marcadamente musical. Por outro, essa alternância se adapta perfeitamente ao revezamento entre as sílabas tônicas e átonas presentes na língua oral. Temos então uma interessante combinação entre a música e a fala.

Enfim, no rap, ora observamos a divisão regular da letra em quatro semicolcheias, ora a divisão alternada com figuras pontuadas e simples. Assim, há no canto dos MC's uma significativa uniformidade rítmica. Mas não somente em relação à melodia. A velocidade da pulsação em todos os raps também varia muito pouco. Na tabela abaixo registramos os andamentos das canções dos cinco álbuns do grupo Racionais MC's. 


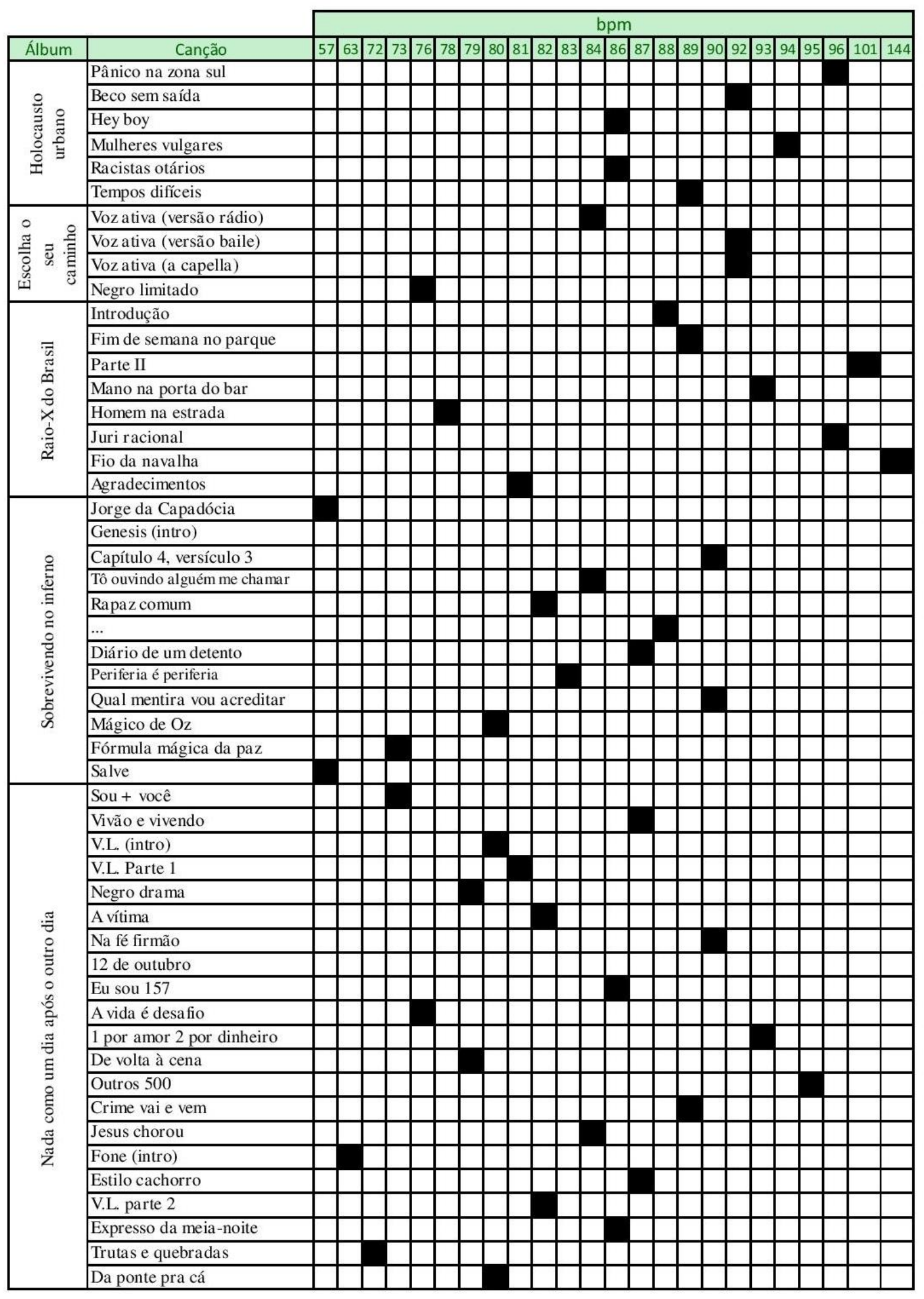

Figura 1.2-8: Velocidade da pulsação nas canções dos Racionais MC's 
Analisando a tabela acima, podemos verificar que os andamentos das canções estão localizados predominantemente entre 73 e 96 batimentos por minuto ${ }^{32}$. Provavelmente, a proximidade desses andamentos é o que torna a subdivisão rítmica da letra praticamente constante. Ou seja, com essa medida de pulsação entre 73 e 96 batimentos $^{33}$, naturalmente o MC entoará a letra de modo que as subdivisões das sílabas sejam predominantemente quatro por unidade de tempo. É importante notar que a subdivisão em quatro partes de uma pulsação com velocidade nessa faixa restrita de bpm é ideal para se cantar o rap de maneira eficaz. Se o andamento da base for muito rápido, a compreensão do texto se perde, o que seria prontamente rejeitado por esses cancionistas que tanto prezam a comunicação com o ouvinte. Se o arranjo for demasiadamente lento, a agressividade do canto do rapper fica comprometida, pois o texto passa a ser emitido com duração mais alongada do que o desejável para o tipo de mensagem transmitida pelos artistas do hip hop.

Nesse sentido, é significativo notar que por vezes os DJ's alteram o andamento das bases sampleadas para adequar a velocidade da pulsação ao canto do MC. Como sabemos, grande parte dessas bases vem do repertório da soul music dos anos sessenta e setenta. Na canção Pânico na zona sul [Faixa 23] dos Racionais MC's, por exemplo, o DJ KL Jay se apropria de Mind Power [Faixa 24] de James Brown para compor o seu arranjo. Mas a música do cantor norte-americano tem o bpm em 104 e a faixa dos Racionais MC's em 96. Ou seja, o DJ alterou em oito pontos para baixo a velocidade da pulsação para que o acompanhamento rítmico ficasse mais lento e adequado ao canto dos rappers. O mesmo é observado em Tempos difíceis [Faixa 25] (bpm 89) que utiliza como base a música Papa Don't Take No Mess [Faixa 26] (bpm 97) também de James Brown. Aqui, podemos escutar claramente a diminuição no andamento realizada pelo DJ e a consequente alteração da altura dos instrumentos harmônicos e melódicos que compõem o arranjo original, pois ao diminuir a velocidade da canção a sua frequência também se altera tornando-se mais grave.

\footnotetext{
3273 bpm (2 ocorrências); 76 bpm (2 ocorrências); 78 bpm (1 ocorrência); 79 bpm (2 ocorrências); 80 bpm (3 ocorrências); 81 bpm (2 ocorrências); 82 bpm (3 ocorrências); 83 bpm (1 ocorrência); 84 bpm (3 ocorrências); 86 bpm (4 ocorrências); 87 bpm(3 ocorrências); 88 bpm (2 ocorrências); 89 bpm (3 ocorrências); 90 bpm (3 ocorrências); 92 bpm (3 ocorrências); 93 bpm (2 ocorrências); 94 bpm (1 ocorrência); 95 bpm (1 ocorrência); 96 bpm (2 ocorrências).

${ }^{33}$ Estamos desconsiderando os andamentos das canções em que não há canto ritmado do rapper: Jorge da Capadócia e Salve (base de Jorge da Capadócia, canção de Jorge Ben Jor); Fone (intro) (falas e diálogos telefônicos); Trutas e quebradas (agradecimentos falados); Fio da navalha (faixa instrumental).
} 
É relevante constatar a coexistência dos processos da tematização e da figurativização em relação a essa característica do rap. Isto é, se por um lado as bases rítmicas são provenientes do repertório da soul music (com padrões rítmicos de músicas ligadas à dança e por isso temáticas), por outro, a velocidade dos seus andamentos é alterada para favorecer a entoação do texto cantado pelo rapper, enfatizando aqui a figurativização.

Enfim, percebemos a existência de uma padronização do parâmetro musical da duração presente em praticamente todas as canções do gênero. Primeiramente, constatamos que a velocidade da pulsação se situa entre 73 e 96 bpm. Depois, verificamos que o ritmo adotado é predominantemente a subdivisão de cada pulsação em quatro partes (as quatro semicolcheias que vemos nas figuras 1.2-3, 1.2-4 e 1.2-5 ou as quatro figuras pontuadas e simples das figuras 1.2-6 e 1.2-7). Dessa maneira, podemos afirmar que a melodia do rap apresenta uma significativa estabilidade rítmica. Sendo assim, por que sentimos tanta figurativização no rap? Ou seja, se podemos comprovar essa marcante estabilidade sonora, por que é tão disseminada a ideia de que a fala (fator de instabilidade musical) é um elemento tão característico do gênero? Acreditamos que a forte presença da língua oral se deve não somente ao fato de o canto do MC se situar em uma região de frequência próxima à da voz falada. Supomos que a estabilidade rítmica comentada acima, contraditoriamente, também favorece o caráter figurativo do rap. Isto é, se todas essas canções atuam ritmicamente com a divisão do pulso em quatro partes e num andamento restrito, então o ouvinte passa a não sentir identidades rítmicas relevantes e a não identificar motivos musicais diferenciados. Como se escutássemos o rap como uma massa de falas homogêneas sem forma musical. Assim, embora as sílabas cantadas pelos rappers sejam organizadas de modo regular no tempo, essa regularidade quase absoluta faz com que, paradoxalmente, o ouvinte não a perceba.

Obviamente, o que mais contribui para a presença da figurativização no rap é o fato de a voz do MC, ao contrário do canto nas canções tonais, não estabilizar a frequência em alturas que coincidem com as notas musicais. Não há a formação de melodias com alturas estáveis, diferenciações intervalares ou configurações de escalas da música tonal. A altura no rap é geralmente a altura da voz falada. Assim, podemos dizer que a melodia do rap não é tonal na medida em que não há ênfase nas relações acordais hierárquicas nem configurações melódicas estáveis o suficiente para que identifiquemos nas notas do canto relações de dominante e tônica, por exemplo. Há sim, 
muitas vezes, um sentido de tensão e resolução na emissão do cantor em diálogo com o fundo musical do DJ, mas sem a estabilização da frequência.

Todavia, há no rap certas ocorrências muito interessantes em relação ao parâmetro altura. Primeiramente, podemos examinar exemplos em que, partindo de uma instabilidade inicial de frequência, a voz se estabiliza e passa a realizar notas musicais reconhecíveis. Em V.L parte $2^{34}$, constatamos variações de altura no canto dos MC's ${ }^{35}$ com uma ascendência do grave para o agudo até a estabilização completa. Assim, a voz traça um caminho que parte da figurativização e chega à tematização melódica. Vejamos esse exemplo de modo mais detalhado.

Dimas, primeiro vida loka da história

Eu digo glória, glória

Eu sei que Deus tá aqui

E só quem é, só quem é vai sentir

E meus guerreiro de fé, quero ouvir quero ouvir

Meus guerreiro de fé quero ouvir

Os três primeiros versos são entoados por Mano Brown com registro próximo ao da voz falada. No quarto verso, o rapper eleva um pouco a frequência quando canta a palavra "é" (terceiro compasso da figura abaixo) e, subitamente, no quinto verso, se mantém no agudo realizando uma melodia perfeitamente estabilizada, ao passear entre as notas Lá b e Sol b sobre uma base claramente tonal, em La b menor.

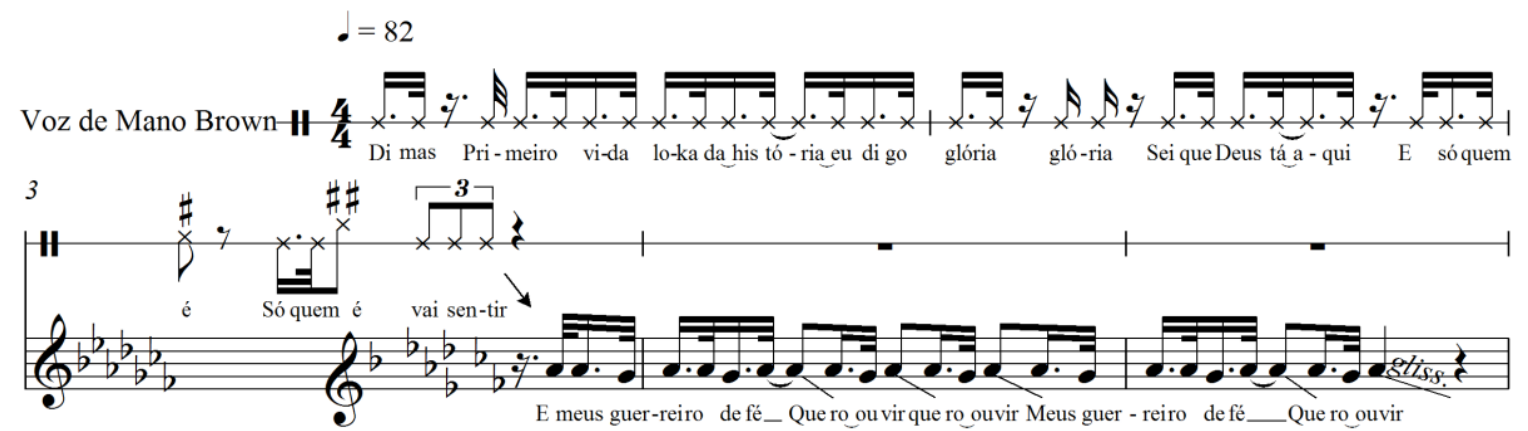

Figura 1.2-9: Voz de Mano Brown em V.L. Parte 2 (Racionais MC's) [Faixa 27]

E na sequencia os versos seguintes formam um refrão totalmente estabilizado na altura e no ritmo:

${ }^{34}$ Nada como um dia após o outro dia (ri depois) (2002)

35 O trecho destacado ocorre de 3'09'" até 3'26'. 
Preparado pra morrer nóis é, certo é certo é

Dê no que der

Nessa mesma canção há outro momento relevante. No trecho transcrito abaixo, constatamos que Mano Brown altera significativamente a altura de sua emissão. O MC inicia a letra em uma tessitura grave e a partir de certo instante passa a cantar em região mais aguda. Em seguida, repentinamente volta para a região grave. Observando a letra do rap, notamos que a altura da voz desloca-se para o agudo na medida em que o discurso se torna mais inflamado. Assim, parece-nos que a elevação da frequência corresponde a um crescimento da tensão na enunciação.

Dinheiro é puta e abre as porta

Dos castelo de areia que quiser

Preto e dinheiro são palavras rivais, é?

Então mostra pra esses cu como é que faz

E seu enterro foi dramático

Como blues antigo

Mas tinha estilo, me perdoe, de bandido

Tempo pra pensar, quer parar?

Que cê quer?

Viver pouco como um rei ou muito como um zé

Às vezes eu acho que todo preto como eu

Só quer um terreno no mato só seu

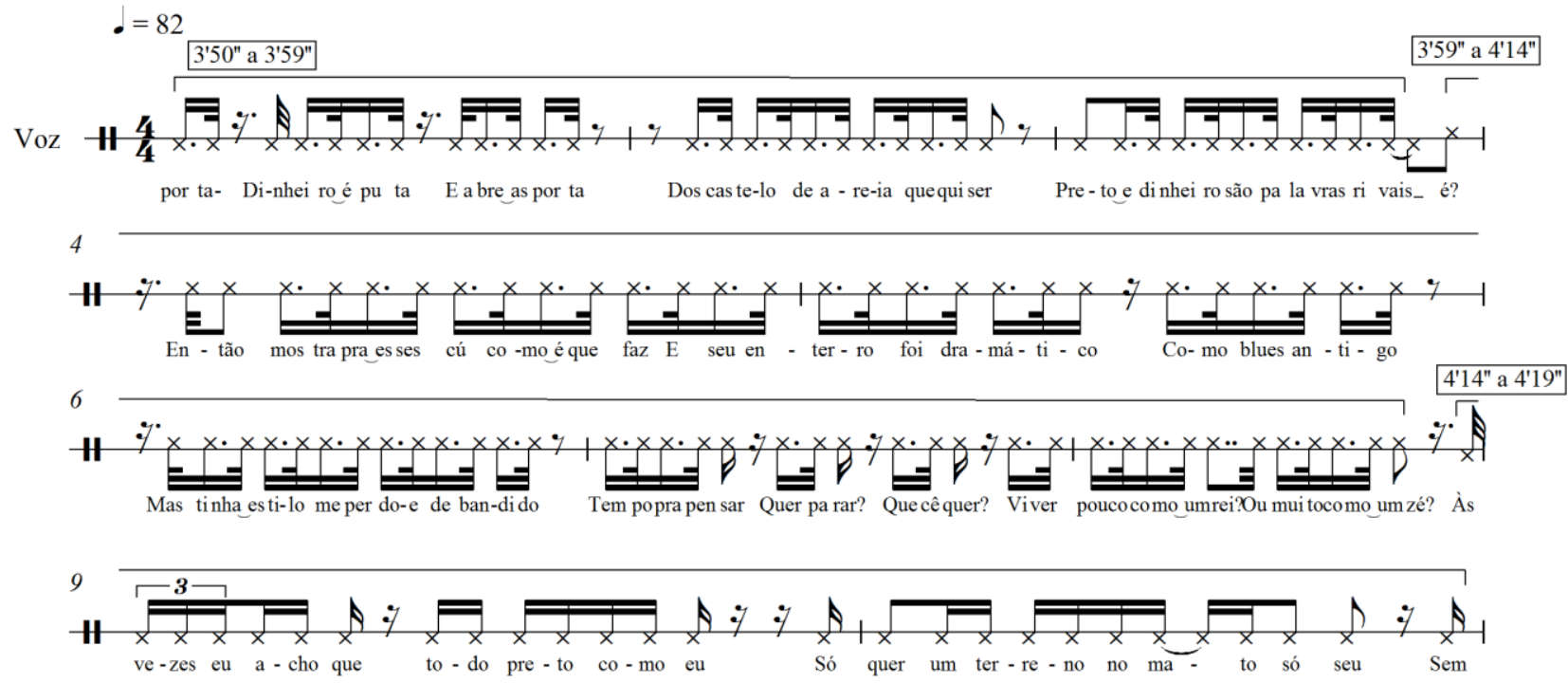

Figura 1.2-10: V.L. Parte 2 (Racionais MC's) [Faixa 28] 
No trecho destacado entre os compassos 4 e 7, a voz do cantor sobe nitidamente na altura ${ }^{36}$ contrastando com a emissão mais grave que surge a partir do compasso 9. São duas maneiras diferentes de entoar a letra, encontradas em muitas interpretações de Mano Brown. No exemplo acima, coexistem numa mesma canção. Esse contraste parece ser uma característica artística do cantor: a oposição entre a sua emissão grave que ouvimos em Diário de um detento [Faixa 29] e a sua emissão mais aguda que escutamos em Negro drama [Faixa 30]. Essa diferença na altura, no entanto, não faz com que o sentido figurativo da canção se perca. Como comentamos acima, a frequência mais aguda pode ser indício de uma fala mais nervosa, de uma emissão mais intensa e agressiva. Como alguém que, irritado, sobe o tom de voz para falar mais enfaticamente. Assim, embora tenhamos essas configurações ligadas à musicalização da letra (formação de certos padrões rítmicos e conformações diferenciadas de frequência), notamos que a fala ainda assim prevalece sobre a música, sendo o aspecto que mais chama a atenção do ouvinte.

A importância do texto verbal faz parte do universo do rap desde a origem do gênero. No Bronx, bairro pobre de Nova York onde o hip hop nasceu, imigrantes jamaicanos organizavam festas nas quais utilizavam os chamados sounds systems, potentes equipamentos de som acoplados a carrocerias de caminhão nos quais eram tocados discos de reggae, funk e soul. Os responsáveis pela execução musical eram chamados de DJ's, em referência aos disc-jóqueis dos programas radiofônicos. Curiosamente, além de cuidarem do repertório da festa, os DJ's também falavam com o público por meio de um microfone, com o intuito de animar os participantes. Essa função, inicialmente exercida pelo próprio DJ, passa a ser realizada por outra pessoa, denominada MC, abreviação de "mestre de cerimônia"37. Assim, percebemos a coexistência, desde os primórdios do rap, das partes musicais do DJ e das partes cantadas/faladas do MC.

A própria repercussão do gênero norte-americano recém-chegado ao Brasil, também nos indica o quanto a sua característica fortemente figurativa chamava a atenção de todos. Em 1979, o produtor, ator e cantor Luís Carlos Miele grava Melô do Tagarela [Faixa 31], uma paródia da canção de grande sucesso internacional, Rapper's Delight [Faixa 32], do grupo estadunidense Sugarhill Gang. A música é por vezes

\footnotetext{
${ }^{36}$ Trecho que ocorre de 3'59' a 4'14'". Na figura, representamos essa subida para o agudo com o desenho da cabeça de cada nota sobre a linha e não abaixo como nos outros dois trechos destacados.

${ }^{37}$ Ver TEPERMAN: 2011: 20
} 
considerada como a primeira canção brasileira do gênero. Miele utiliza trechos do arranjo instrumental da versão americana e imita o seu canto falado apelidando-o de "tagarela". Assim, somente pelo título dado à versão brasileira, já podemos verificar o quanto a presença da língua oral é a marca principal desse tipo de canção.

Há muitas pesquisas etimológicas relacionadas à palavra $\operatorname{rap}^{38}$. Em todas elas observamos igualmente essa ligação com a fala. A origem mais aceita e difundida é a que identifica no vocábulo "rap" uma sigla para a expressão rhythm and poetry. Aqui, não há qualquer menção à altura ou às notas musicais. Portanto, o gênero se definiria como a junção entre um ritmo e um texto verbal. Há também estudiosos ou MC's brasileiros que consideram o rap como uma variação de gêneros nordestinos como o repente e a embolada (canções muito figurativas). Há ainda quem defenda a ideia de que a sigla RAP significa "revolução através das palavras" (novamente a palavra à frente da música). Por fim, há explicações etimológicas ligadas aos concursos verbais e desafios cantados. Lembramos que o vocábulo "rap" já estava dicionarizado na língua inglesa desde o século XIV, como um verbo com sentido de "bater" ou "criticar". Assim, nesses jogos verbais, talvez ganhasse o significado de "bater com as palavras". Práticas lúdicas como os toasts (longos relatos rimados geralmente de conteúdo violento e obsceno) e o the dozens ou dirty dozens ${ }^{39}$ (desafio verbal no qual os participantes fazem insultos uns aos outros, igualmente rimados) são indícios de outra possível origem para o termo ${ }^{40}$. Sobretudo quando pensamos nas atuais batalhas de freestyle (concursos de improvisos cantados), manifestações tão importantes para o hip hop brasileiro contemporâneo. Diante de tantas suposições em relação à origem do nome rap, nos interessa somente assinalar que todas as explicações etimológicas elencadas acima destacam a forte presença do elemento verbal.

Por outro lado, o sentido de "rap" dicionarizado na língua inglesa como "bater" ou "criticar" também demonstra a íntima ligação entre a presença da fala e a presença de um discurso de protesto. Isto é, começamos a perceber que o processo figurativo, por sua proximidade em relação ao registro da língua oral, é provavelmente o mais adequado ou natural para que os MC's possam transmitir suas mensagens. Logo, não podemos analisar o rap sem considerar de alguma maneira o seu sentido político, pois sua carga ideológica (a reclamação constante por melhores condições de vida para a

\footnotetext{
38 Ver TEPERMAN, 2011: 21

${ }^{39}$ Ver BÉTHUNE , $1999: 139$

${ }^{40}$ Ver TEPERMAN: 2011: 84
} 
população pobre) influi diretamente na constituição de sua forma artística: a pobreza de uma população fomenta a contestação e esse questionamento é mais eficiente quando realizado por meio do processo figurativo, e não a partir do uso de outros recursos como a tematização ou a passionalização. Walter Garcia já havia discutido essa questão.

Ora, se o propósito do Racionais é passar uma mensagem crítica por meio da letra, a figurativização é o recurso mais adequado para isso. E o rap é o estilo de canção no qual esse recurso é mais essencial (GARCIA, 2003: 59)

Portanto, é importante destacarmos na história do rap a sua ligação com a vida violenta das periferias das grandes cidades e com a afirmação dos direitos dos negros. Como dissemos anteriormente, o gênero nasceu no início da década de 1970, no Bronx, bairro de Nova York localizado ao norte da ilha de Manhatann. Na época, a região era habitada por uma população pobre predominantemente negra e apresentava uma condição social extremamente precária, com altos índices de violência urbana, sobretudo com as frequentes disputas entre gangues rivais. Além disso, a sociedade americana ainda sofria as repercussões geradas pela atuação dos movimentos negros nos anos 1960. É nesse contexto fortemente político que se dá o nascimento do rap nos EUA, como uma consequência cultural das injustiças históricas sofridas pela população americana marginalizada.

Hip hop é uma forma cultural que tenta combinar as experiências de marginalização, as oportunidades brutalmente negadas e a opressão presente nos imperativos culturais da história, identidade e comunidade Afro-Americana e Caribenha. (ROSE, 1994: 21) ${ }^{41}$

Assim como no caso norte-americano, o rap brasileiro, desde sua origem, sempre se mostrou muito politizado ${ }^{42}$. No início dos anos 1980, o hip hop começa a se popularizar no Brasil em decorrência do sucesso internacional do rap, mas, sobretudo, da dança break, presente em propagandas e programas televisivos. Em meados da década, começam a se reunir na estação São Bento do metrô de São Paulo, dançarinos

\footnotetext{
${ }^{41}$ Hip hop is a culture form that attempts to negotiate the experiences of marginalization, brutally truncated opportunity, and oppression within the cultural imperatives of African-American and Caribean history, identity, and community. (ROSE, 1994: 21)

${ }^{42}$ Refiro-me aqui aos grupos mais expressivos da música brasileira. Obviamente, há rappers que não apresentam em suas letras a temática do confronto social. Nesse momento, no entanto, como queremos estabelecer relações entre a o processo figurativo e o conteúdo de protesto, nos interessa, sobretudo, os grupos que levavam para seus raps mensagens politicamente engajadas.
} 
de break (os chamados b-boys), frequentadores de bailes black da capital e simpatizantes do novo gênero de música americana. O local se torna o principal foco do movimento hip hop no Brasil, frequentado por artistas como Thaíde e DJ Hum e por integrantes do grupo Racionais MC's, todos ainda desconhecidos. Posteriormente, os praticantes de rap passam a se reunir na Praça Roosevelt. A estação São Bento se mantém como ponto de encontro dos dançarinos de break e os frequentadores mais interessados na música do hip hop e em suas questões políticas passam a visitar o novo local. É nesse novo espaço que surgem as primeiras posses brasileiras, organizações formadas por praticantes do hip hop em suas variadas formas artísticas ${ }^{43}$. Nas posses, artistas e simpatizantes do movimento se reúnem com o objetivo de promover apresentações musicais, festas, eventos educativos, discussões e debates, sempre com o intuito de estimular a conscientização social do público. Entre as muitas organizações desse tipo que surgiram no Brasil, destaca-se a CUFA ${ }^{44}$ (Central Única das Favelas). Um de seus fundadores é o conhecido rapper MV Bill. Com o surgimento das posses, o hip hop e, sobretudo o rap, explicita e institucionaliza a sua propensão natural para a discussão política e denúncia. Dessa maneira, verificamos que essa tendência ideológica é componente fundamental para esse gênero de canção.

A questão política é tão proeminente que, geralmente, os estudiosos do rap nem chegam a discutir a forma artística adotada pelos compositores, considerando em suas análises apenas o conteúdo contestatório das letras. No limite, não haveria diferença entre estudar uma canção de Mano Brown ou uma entrevista do rapper na imprensa. Nosso trabalho, ao contrário, pretende voltar-se para a matéria artística propriamente dita. É preciso encontrar a força política do rap na própria linguagem cancional. Primeiramente, investigar de que maneira essa linguagem (tão próxima à fala) torna-se um fator importante para o objetivo de conscientização política dos MC's. E, posteriormente, estudar de que forma a musicalização (a procura dos rappers por sonoridades estáveis com ritmos e rimas) também pode atuar em prol dessa mesma força política. Enfim, um discurso sem preocupação musical ou artística não possui o mesmo tipo de expressividade alcançado pelos raps. Uma entrevista não substitui uma canção.

\footnotetext{
${ }^{43} \mathrm{O}$ hip hop é formado por quatro elementos: o MC, o DJ, o grafite e o break.

${ }^{44}$ A CUFA foi criada no Rio de Janeiro em 2000 e possui filiais em diversos estados brasileiros.
} 
Tomando o primeiro aspecto como objeto de análise, podemos constatar que a maneira com que o MC traz à tona a questão social (denúncia geralmente realizada com afronta e agressividade) está intimamente relacionada a essa proximidade com a língua oral, sobretudo na forma combativa adotada na entoação da letra. Walter Garcia, ao analisar a canção Diário de um detento, ressalta o modo de dizer do rapper Mano Brown. Essa maneira de dizer, sua fala ofensiva, é um dado fundamental para o impacto gerado pelas canções do grupo.

Sobre a dicção de Mano Brown já foi dito, carrega agressividade. O modelo é norteamericano, mas a realização é brasileira. Ainda que o significado das palavras não fosse compreensível, seu jeito de cantar, ou mais propriamente, a matéria de sua voz afronta a humilhação a que negros são aqui submetidos historicamente. Na perspectiva do dominador, é a voz de um folgado que não tolera o seu lugar inferior no sistema social. (GARCIA, 2007: 200)

Mas essa característica figurativa, além de muito apropriada para o protesto, também propicia algo muito valorizado no universo do rap: a aproximação entre o artista e o público. Segundo Maria Rita Kehl (2000), notamos no hip hop outro tipo de interação entre essas duas esferas. Há nesse gênero uma recusa em relação à separação extrema entre a massa de ouvintes e o artista excepcional. Critica-se até mesmo a ascensão social do artista negro ligada à lógica do mercado na qual alguns poucos indivíduos são aceitos e se transformam em objetos de veneração para uma "grande massa de fãs que sonham individualmente com a sorte de um dia também virarem exceção" (KEHL, 2000: 211). O rap, ao contrário, procura se guiar a partir do lugar do semelhante. Dessa forma, os fãs de rap tendem a falar de igual para igual com seu ídolo, “como se cada um deles se considerasse um rapper em potencial” (KEHL, 2000: 209).

\footnotetext{
A força dos grupos de rap não vem de sua capacidade de excluir, de colocar-se acima da massa e produzir fascínio, inveja. Vem de seu poder de inclusão, da insistência na igualdade entre artistas e público, todos negros, todos de origem pobre, todos vítimas da mesma discriminação e da mesma escassez de oportunidades (KEHL, 2000: 226)
}

Essa comunicação próxima entre autor e público é tão marcante no rap que há casos em que ela constitui a própria canção. Curiosamente, nos álbuns do grupo Racionais MC's, notamos faixas compostas apenas por dedicatórias e agradecimentos 
falados pelos rappers com fundo musical do DJ, dirigidos às comunidades pobres e amigos espalhados pelo país: Agradecimentos (In: Raio X do Brasil, 1993), Salve (In: Sobrevivendo no inferno, 1998), Trutas e quebradas (In: Nada como um dia após o outro dia, 2002). Pesquisando a discografia dos grupos e rappers brasileiros mais importantes também encontramos diversas faixas de agradecimento $^{45}$ : Salve as quebradas (In: De menos crime, Rap das quebradas), Familia G.O.G. agradece (In: GOG - CPI da favela, 2000), Pode crê (In: GOG, Das trevas à luz, 1998), Agradecido (In: MRN - Tudo novo d novo, 2007), Sem Esquecer as Favelas (In: MV Bill Traficando Informação) e Salve (In: Sistema Negro - Renascendo das Cinzas). Além disso, encontramos muitas músicas em que os MC's se dirigem diretamente ao público. É muito comum nos discos de rap a existência de faixas introdutórias nas quais os cantores convidam diretamente seus ouvintes para a audição do álbum. Nesse sentido, ao observarmos as primeiras faixas de todos os discos dos Racionais MC's, notamos o forte diálogo com a comunidade, a afirmação do grupo e as marcações temporais.

Aqui é Racionais MC's. Ice Blue, Mano Brown, KL Jay e eu, Edy Rock

- E aí Mano Brown, certo?

- Certo não está né mano. E os inocente? Quem os trará de volta?

- É, a nossa vida continua, quem se importa?

- A sociedade sempre fecha as portas mesmo, cara. E aí Ice Blue?

In: Pânico na zona sul. Álbum Holocausto urbano (1990) [Faixa 33]

Mil novecentos e noventa e dois. A juventude negra agora tem voz ativa

Viemos mostrar que a sabedoria de rua vale muito

E não se aprende nas escolas e tal

Das ruas de São Paulo pro mundo: Racionais

In: Voz ativa (versão rádio). Álbum Escolha o seu caminho (1992) [Faixa 34]

Mil novecentos e noventa e três

Fudidamente voltando

Racionais

Usando e abusando da nossa liberdade de expressão

\footnotetext{
45 Foram pesquisadas as discografias dos seguintes grupos e artistas: Consciência Humana, Criolo, Emicida, De menos crime, Facção Central, Faces do subúrbio, GOG, MRN, MV Bill, Posse Mente Zulu, Racionais MC's, RZO, Sabotage, Sistema Negro, SNJ, Thaíde \& DJ Hum e Xis.
} 
Um dos poucos direitos que o jovem negro ainda tem nesse país

Você está entrando no mundo da informação, autoconhecimento, denúncia e diversão

Esse é o raio $\mathrm{X}$ do Brasil, seja bem-vindo.

In: Introdução. Álbum Raio X do Brasil (1993) [Faixa 35]

Deus fez o mar, as árvore, as criança, o amor

O homem me deu a favela, o crack, a trairagem, as arma, as bebida, as puta

$\mathrm{Eu}$ ?

Eu tenho uma bíblia velha, uma pistola automática, um sentimento de revolta

Eu tô tentando sobreviver no inferno

In: Genesis (intro). Álbum: Sobrevivendo no inferno (1998) [Faixa 36] ${ }^{46}$

Benção mãe

Estamos iniciando nossas transmissões

Essa é a sua rádio Êxodos

Hey, hey,

Vamo acordar, vamo acordar

Porque o sol não espera, demorou, vamo acordar

O tempo não cansa

Ontem à noite você pediu, você pediu

Uma oportunidade, mais uma chance

Como Deus é bom, Né não nego?

Olha aí, mais um dia todo seu

Céu azul loco hein?

Vamo acordar, vamo acordar

Agora vem com a sua cara, sou mais você nessa guerra, a preguiça é inimiga da vitória, o fraco não tem espaço e o covarde morre sem tentar.

Não vou te enganar, o bagulho tá doido, ninguém confia em ninguém,

\footnotetext{
46 Na música de abertura desse álbum, o diálogo com a comunidade não é realizado de forma tão explícita. A primeira faixa do disco é Jorge da capadócia do compositor Jorge Ben Jor, cantada como música incidental sem acréscimo de letra por parte dos rappers. A segunda faixa e início da terceira cumprem um pouco essa função introdutória usualmente utilizada nos discos do grupo. A segunda, também denominada como "intro", chama-se Genesis, título significativo tendo em vista a temática religiosa que perpassa todo o álbum. E na faixa seguinte, Capítulo 4, versículo 3, escutamos a voz de Primo Preto enviar um recado mais direto ao ouvinte (que nesse caso pode ser tanto a sociedade brasileira em geral quanto o morador das periferias): "Sessenta por cento dos jovens de periferia sem antecedentes criminais já sofreram violência policial. A cada quatro pessoas mortas pela polícia três são negras. Nas universidades brasileiras apenas dois por cento dos alunos são negros. A cada quatro horas um jovem negro morre violentamente em São Paulo. Aqui quem fala é Primo Preto, mais um sobrevivente."
} 
Nem em você, os inimigos vêm de graça, é a selva de pedra, ela esmaga os humildes demais, você é do tamanho do seu sonho, faz o certo, faz a sua, vamo acordar, vamo acordar, cabeça erguida,

Olhar sincero, tá com medo de quê?

Nunca foi fácil, junta os seus pedaços e desce pra arena, mas lembre-se: aconteça o que aconteça

Nada como um dia após o outro dia

In: Sou + você. Álbum Nada como um dia após o outro dia (chora agora) (2002) [Faixa 37]

É tru, Racionais tá aí de novo, morô?

E os caras há mili ano na parada, pode crê,

Os cara representa a favela do começo ao fim,

Mas aí, é muita treta hein? É ideia de mil grau no bagulho.

In: De volta à cena. Álbum Nada como um dia após o outro dia (ri depois) (2002) [Faixa 38]

Ou seja, esse posicionamento político de se dirigir diretamente ao seu público faz com que, significativamente, o rap seja o único gênero no qual os agradecimentos estão nas próprias músicas e não somente no encarte do disco. Além disso, o MC frequentemente cita nomes de amigos e de lugares de seu cotidiano em suas canções. Ou seja, essa aproximação entre autor e ouvinte ocorre sempre de maneira muito natural. Música feita na periferia, para a periferia. Não é a toa que o rap nacional desenvolveu um sistema de produção cultural independente da grande mídia, sempre ligado às rádios comunitárias e apresentações nos bairros pobres dos grandes centros urbanos.

Algo interessante pode ser observado no álbum Nada como um dia após o outro dia (ri depois) dos Racionais MC's. Após a faixa Trutas e quebradas [Faixa 39] (na qual os rappers agradecem amigos e comunidades) ouvimos a canção Da ponte pra cá [Faixa 40], na qual há um trecho inicial falado ${ }^{47}$ em que um locutor de rádio envia agradecimentos e dedicatórias de pessoas de uma comunidade para habitantes de outros bairros periféricos, prática muito comum nas programações das rádios comunitárias brasileiras. Assim, além dos integrantes dos Racionais MC's enviarem seus próprios recados para as comunidades, há também espaço (ou a simulação artística desse espaço) para os ouvintes trocarem mensagens entre si, demonstrando o quanto a comunicação e a identificação do rap com as vozes da periferia são fundamentais no universo do hip hop.

\footnotetext{
${ }^{47} \mathrm{O}$ trecho destacado ocorre de $0{ }^{\prime} 00^{\prime}$ ' a $0{ }^{\prime} 45^{\prime}$ ”.
} 
Esse fator da comunicação com o público está igualmente marcado na própria trajetória artística dos Racionais MC's, no que se refere ao nível de coloquialidade de suas letras. Por exemplo, como os próprios rappers afirmam, havia no início de carreira uma formalidade maior em relação à escolha lexical. As construções verbais se afastavam da coloquialidade para que se evitasse um registro linguístico ordinário. Essa atitude artística representava então um importante posicionamento político para o grupo. Aos poucos, no entanto, os integrantes deixam de lado esse registro mais formal e passam a incorporar a fala cotidiana em suas canções.

situações violentas são narradas com "palavras de rua mesmo", um recurso que veio sendo conquistado a cada disco, conforme os rappers já disseram em mais de uma entrevista (inicialmente o grupo queria "ser intelectual, falar umas palavras difíceis", com "medo de ser mal interpretado, medo da música ser vulgar”). Também a sintaxe popular é empregada contra o preconceito linguístico e a favor da comunicação com a periferia (GARCIA, 2003: 177)

Assim, a adoção de uma linguagem mais próxima à fala cotidiana, com, por exemplo, a incorporação de gírias antes evitadas, torna-se igualmente um posicionamento político. Observamos até mesmo que o apelo de público do grupo cresce significativamente na medida em que a linguagem empregada chega ao ouvinte de maneira mais coloquial e íntima. A comunicação se fortalece. Notamos aqui, sem dúvida, um amadurecimento artístico desses cancionistas observado, sobretudo, a partir de Raio X Brasil, álbum de 1993. Nos discos anteriores, o emprego de termos da linguagem culta e a eliminação de gírias presentes na língua falada eram procedimentos utilizados para que suas obras não fossem confundidas com discursos vulgares e sem valor. Assim, a obra podia ganhar aspecto de obra: a inserção dessa formalidade linguística daria relevância ao que estavam fazendo. É interessante notar que a partir de Raio X Brasil, ao mesmo tempo em que a coloquialidade passa a ser incluída nas letras, os versos tornam-se formalmente mais trabalhados nas sonoridades dos vocábulos e nas configurações rítmicas dadas aos textos verbais.

Mas essa tendência figurativa não atua somente no sentido de aproximar o rapper de seu público. Ela também proporciona uma aproximação entre o compositor e o intérprete. No rap, o trabalho do cantor e o trabalho do letrista são esferas praticamente indissociáveis, pois não há intérprete que não cante suas próprias criações. O impulso figurativo explicita um modo de dizer, a dicção de cada MC. Constatamos 
uma maior presença da individualidade verbal de cada artista e essa maneira de entoar muitas vezes representa a própria composição. A ausência de notas musicais estáveis na sua melodia também colabora para isso, já que explicita o uso do registro da fala, chamando a atenção do ouvinte para um modo de dizer muito individualizado. Assim, interpretar uma canção de Mano Brown pode tornar-se uma tarefa um tanto complicada. Se em outros gêneros musicais é muito frequente a separação entre a figura do intérprete e a figura do compositor, no rap, ao contrário, pode-se afirmar que letrista e cantor se confundem praticamente na totalidade das situações.

A figurativização é tão marcante que pode provocar até mesmo uma fortíssima sensação de realidade. O ouvinte, ao perceber que os versos cantados estão próximos da linguagem do cotidiano, passa a considerá-los como verdadeiros. Esse fator é algo extremamente valorizado no universo do hip hop. O efeito de verdade das letras de rap sempre fez parte da fruição desse tipo de canção, pois, como já mencionamos acima, ela é fruto direto das experiências vividas pelas comunidades pobres. Como o rap sempre esteve ligado aos artistas da periferia, entendemos o porquê de tanta polêmica quando surgem na mídia MC's pertencentes a classes sociais mais abastadas. A legitimidade de cantar a pobreza não é dada a qualquer artista. Por outro lado, essa confusão entre a composição e o mundo real gera por vezes fatos inusitados. No início de 2014, o jornal The New York Times publicou matéria a respeito do uso de letras de rap em processos judiciais nos $\mathrm{EUA}^{48}$. As canções são usadas por promotores como provas de envolvimento de rappers em crimes diversos.

As letras e vídeos de rap estão aparecendo como provas nas salas de audiência de todo o país com regularidade alarmante. No ano passado, a Associação Americana das Liberdades Civis de Nova Jersey descobriu que em 18 processos nos quais várias cortes consideraram a admissibilidade do rap como evidência, as letras foram permitidas em quase 80 por cento das vezes.

E mais adiante:

Stuart Fischoff, psicólogo da Universidade Estadual da Califórnia, Los Angeles, conduziu um estudo no final da década de 1990 para medir o impacto das letras do gangsta rap nos jurados. Os participantes receberam informações biográficas básicas de um hipotético negro de 18 anos, mas apenas alguns receberam um grupo das suas letras de rap violentas e

\footnotetext{
${ }^{48}$ Matéria de Erik Nielson e Charis E. Kubrin traduzida e publicada no jornal O Globo em 17/01/2014. In: http://oglobo.globo.com/mundo/letras-de-rap-em-julgamento-nos-estados-unidos-11318331
} 
sexualmente explícitas. Os participantes que leram as letras ficaram significantemente mais propensos a acreditar que o homem era capaz de cometer um assassinato do que os que não leram.

Obviamente, não podemos esquecer que por trás dessas medidas judiciais há claramente um teor discriminatório em relação aos indivíduos acusados. Há questões sociais aí implicadas que também influem no uso equivocado das letras das canções como provas de atos criminosos. No entanto, acredito que não seja apenas pelo fato de o rap retratar o universo da criminalidade que frequentemente autoridades associam o conteúdo das letras ao mundo real. Certamente, a forma da canção, predominantemente figurativa, colabora de maneira significativa para que se aumente essa impressão de realidade. E essa é uma característica importantíssima para o gênero, pois quanto maior for o seu efeito de verdade, maior será a força da sua denúncia. Nesse sentido, a fusão entre a figura do bandido e a figura do rapper é muito eficiente. $\mathrm{O}$ grupo Racionais MC's, por exemplo, em muitas de suas canções, costuma utilizar a comparação poética entre o ato criminoso e a atividade artística. É como se Mano Brown empregasse o mesmo grau de violência do assaltante que ataca a sua vítima para agredir a elite brasileira.

Meu estilo é pesado e faz tremer o chão

Minha palavra vale um tiro... eu tenho muita munição

(...)

Uni-duni-tê, eu tenho pra você

Um rap venenoso ou uma rajada de PT

In: Capítulo 4, versículo 3, álbum Sobrevivendo no inferno, 1998

Esse tipo de imagem poética possui até mesmo uma tradição histórica. Christian Béthune, em seu livro Le rap: une esthétique hors la loi, faz interessantes aproximações entre a história do rap e a história do jazz norte-americano. Um dos pontos de contato entre os dois gêneros artísticos é, segundo o autor, essa frequente comparação entre o ato musical e o uso agressivo de uma arma. 
O músico de jazz recentemente comparou o seu instrumento a um machado e a sonoridade que tirava dele ao gume afiado de uma faca; nas mãos do $\mathrm{MC}$, o microfone se torna uma arma, e as palavras saem de sua garganta como tiros mortais (BÉTHUNE, 1999: 71) ${ }^{49}$

A presença da figurativização no rap também pode provocar outras questões polêmicas. Primeiramente, ainda que de forma geralmente ingênua, discute-se a validade da sua condição de gênero musical. Pelo fato de o cantor adotar o registro da fala e não estabilizar a melodia com notas musicais disseminou-se a ideia de que o rap nada mais é do que a declamação de uma letra sobre uma base rítmica. Não nos interessa aqui determinar se o rap é ou não é um gênero musical, pois o conceito de categoria musical pode variar de cultura para cultura, de época para época. É preciso apenas constatar que grande parte dos ouvintes está acostumada somente com a audição de música tonal (melodia acompanhada por acordes e formada por alturas afinadas). Por isso, quando o público se depara com gêneros populares como o rap e o funk carioca ou com peças eruditas de compositores contemporâneos (que trabalham mais os aspectos rítmicos, texturais e timbrísticos do que com o tonalismo) o estranhamento é inevitável. Em relação ao rap, esse estranhamento decorre, sobretudo, dessa sua proximidade com a fala.

Outra questão interessante decorrente dessa propensão figurativa é a constituição da identidade do gênero. Afinal, o que é o rap? Veremos ao longo dessa pesquisa que esse tipo de canção apresenta elementos sonoros muito heterogêneos: falas diretas sem nenhuma musicalização, frases verbais ritmadas, refrãos cantados com alturas e padrões de duração estáveis, acompanhamento musical do DJ, samples de canções de outros autores, etc. Dessa maneira, como poderíamos defini-lo? É rap apenas o canto ritmado do MC ou todo esse universo sonoro complexo? Como vimos, para o ouvinte comum, o que primeiro chama a atenção é o peso da figurativização na relação entre a melodia e a letra. É o que o distingue de outros universos cancionais. Assim, geralmente se entende como rap somente o canto falado do MC, sem considerar os trechos cantados com alturas definidas ${ }^{50}$. Entretanto, essa posição é questionável na medida em que há exemplos nos quais o próprio MC varia o grau de musicalização da letra e até mesmo

\footnotetext{
${ }^{49}$ Le musicien de jazz comparait naguère son instrument à une hache (axe) et la sonorité qu'il en tirait au fil tranchant d'une arme blanche; entre les mains du MC, le micro devient un flingue, et les paroles fusent de son gosier comme des projectiles mortifères. (BÉTHUNE, 1999: 71)

${ }^{50}$ Como veremos nos próximos capítulos, há diversas canções que apresentam partes temáticas e passionais (geralmente interpretadas por outros cantores) que se alternam em relação às partes mais faladas dos MC's.
} 
chega a estabilizá-la fortemente, como vimos na figura 1.2-9, na melodia da voz de Mano Brown em V.L. Parte 2. Melhor dizendo, podemos perceber que a identidade do rap possivelmente se constrói a partir da convivência entre os processos ligados à fala e os processos de musicalização. Aliás, como em qualquer canção. Retomando o fragmento de Walter Garcia já comentado anteriormente.

\footnotetext{
Ora, se o propósito do Racionais é passar uma mensagem crítica por meio da letra, a figurativização é o recurso mais adequado para isso. E o rap é o estilo de canção no qual esse recurso é mais essencial, pois a melodia do rap se constrói apenas pelo ritmo, enquanto as notas musicais são substituídas pela sonoridade da letra (entoação, rimas, assonâncias, aliterações) e pelo timbre do rapper (o timbre sugere a altura da emissão de acordo com o fundo musical). Fundamentalmente, o jogo rítmico entre a voz e o acompanhamento é a garantia de que cantar rap não é o mesmo que declamar um poema sobre um fundo musical: o rap quer passar uma idéia sem deixar de envolver todo o corpo do ouvinte (GARCIA, 2003: 59)
}

Constatamos no texto acima que há uma tensão entre a fala e a música. Se, por um lado, o autor afirma que a figurativização é o seu processo essencial, por outro, destaca a presença do ritmo, da sonoridade da letra, e da relação musical entre o ritmo do acompanhamento e o ritmo das frases verbais. Até mesmo a questão corporal, mais ligada ao processo da tematização, aparece: "O rap quer passar uma ideia sem deixar de envolver todo o corpo do ouvinte". Trata-se, no entanto, de um conflito muito natural no âmbito do hip hop, presente desde sua mais remota origem. Basta pensarmos na oposição entre a fala do MC e a música do DJ. Como já comentamos, os equipamentos de som eram levados para as ruas nas festas do Bronx com o propósito de suscitar a dança. Afinal, os discos eram de música dançante: funk, soul e reggae. E ao mesmo tempo, no meio dessa estabilidade musical havia o momento em que se falava com o público com o auxílio de um microfone. É interessante relembrar que, inicialmente, a pessoa responsável por tocar as músicas também falava ao microfone. Ou seja, os papéis de DJ e MC eram então realizados por um único indivíduo. A tensão estava circunscrita a um só sujeito. Ao longo do tempo, pela dificuldade de desempenhar essas duas funções simultaneamente, elas passam a ser executadas por pessoas distintas. Enfim, constatamos que a coexistência entre a música/dança e a fala é uma característica fundadora para o universo do rap. Se há, por um lado, a importância do entendimento da mensagem do $\mathrm{MC}$, por outro, há a fruição musical do 
acompanhamento musical do DJ que pode fazer com que o ouvinte se distancie ou se aproxime dessa mensagem. No rap essa questão está sempre colocada. Sobre Diário de um detento, afirma Walter Garcia:

Já a dignidade e o corpo são resgatados, nessa canção, por um balanço que favorece mais o entendimento das palavras do que a dança. A rigor, a periferia não dança Racionais: canta junto, dramatiza a letra e balança o corpo (GARCIA, 2007: 186)

A musicalização do rap não pode ser excessiva a ponto de prejudicar a compreensão do texto, ou melhor, de chamar mais atenção do que ele. A dança não pode ser exagerada, pois ela não é o seu intuito principal. Balançar demasiadamente o corpo poderia significar a falta de envolvimento do público com o conteúdo da letra. No entanto, notamos que, por vezes, a mensagem do texto pode chegar ao ouvinte mesmo sem o entendimento integral das palavras. Isto é, apenas pelo gesto do rapper, por sua atitude, a plateia consegue apreender intuitivamente e corporalmente o seu significado. A entoação de Mano Brown, carregada de agressividade, por si só já nos possibilita captar o teor do seu recado. Por isso, mesmo quando escutamos uma canção em língua estrangeira com a qual não temos familiaridade, percebemos o sentido geral do texto apenas pelo modo como o cantor entoa a letra. Por fim, é relevante comentar que Garcia identifica entre os próprios cantores do grupo Racionais MC's uma variação em relação à presença figurativa. $\mathrm{O}$ canto do rapper Ice Blue apresenta-se mais musicalizado do que a interpretação de Mano Brown. Assim, constatamos que a tensão entre a fala e a música é algo que está presente no rap em diferentes níveis.

O acompanhamento feito por KL Jay orienta as performances de Mano Brown, canto falado mais próximo da fala e do intelecto, e de Ice Blue, canto falado mais próximo do canto e da dança (GARCIA, 2007: 196)

Nesse capítulo, pudemos constatar não apenas a importância da figurativização no rap, algo muito evidente para os ouvintes, mas, sobretudo, os seus diferentes modos de manifestação, desde a inserção de falas diretas, sem qualquer preocupação de estabilidade, até o texto ritmado e musicalizado do rapper. Vimos algumas razões, consequências e até implicações sociais do uso do processo figurativo no rap. Discutimos, ao final, a tensão entre os elementos entoativos e os recursos musicais observada nas canções e mesmo na história do gênero (representada pelas figuras do 
MC, ligado à fala, e do DJ, ligado à música). Isso nos leva diretamente para o próximo passo da pesquisa, a investigação sobre a musicalização no rap por meio da tematização. 


\section{Tematização}

\subsection{A melodia temática}

O segundo modo de compatibilização entre a melodia e a letra na canção popular tem como fator decisivo o aspecto musical. Ainda que o elemento entoativo esteja sempre presente, o germe criativo não provém necessariamente da relação estreita com as leis características da língua oral, mas sim da constituição de padrões rítmicomelódicos que se relacionam com o conteúdo do texto linguístico. Como veremos nos exemplos seguintes, esse maior interesse pela informação musical e pela estabilização de temas torna alguns procedimentos figurativos extremamente indesejáveis. A elasticidade melódica observada em canções de Jorge Ben Jor, por exemplo, na qual o padrão musical é sempre corrompido pela energia entoativa, é evitada em favor da regularidade motívica. Essa regularidade, por sua vez, faz com que a canção tematizante esteja intimamente ligada aos gêneros musicais de dança, nos quais a reiteração rítmica é fundamental.

Vem morena pros meus braços

Vem morena vem dançar

Quero ver tu requebrando

Quero ver tu requebrar

Quero ver tu remexer no resfolego da sanfona até que o sol raiar

Quero ver tu remexer no resfolego da sanfona até que o sol raiar
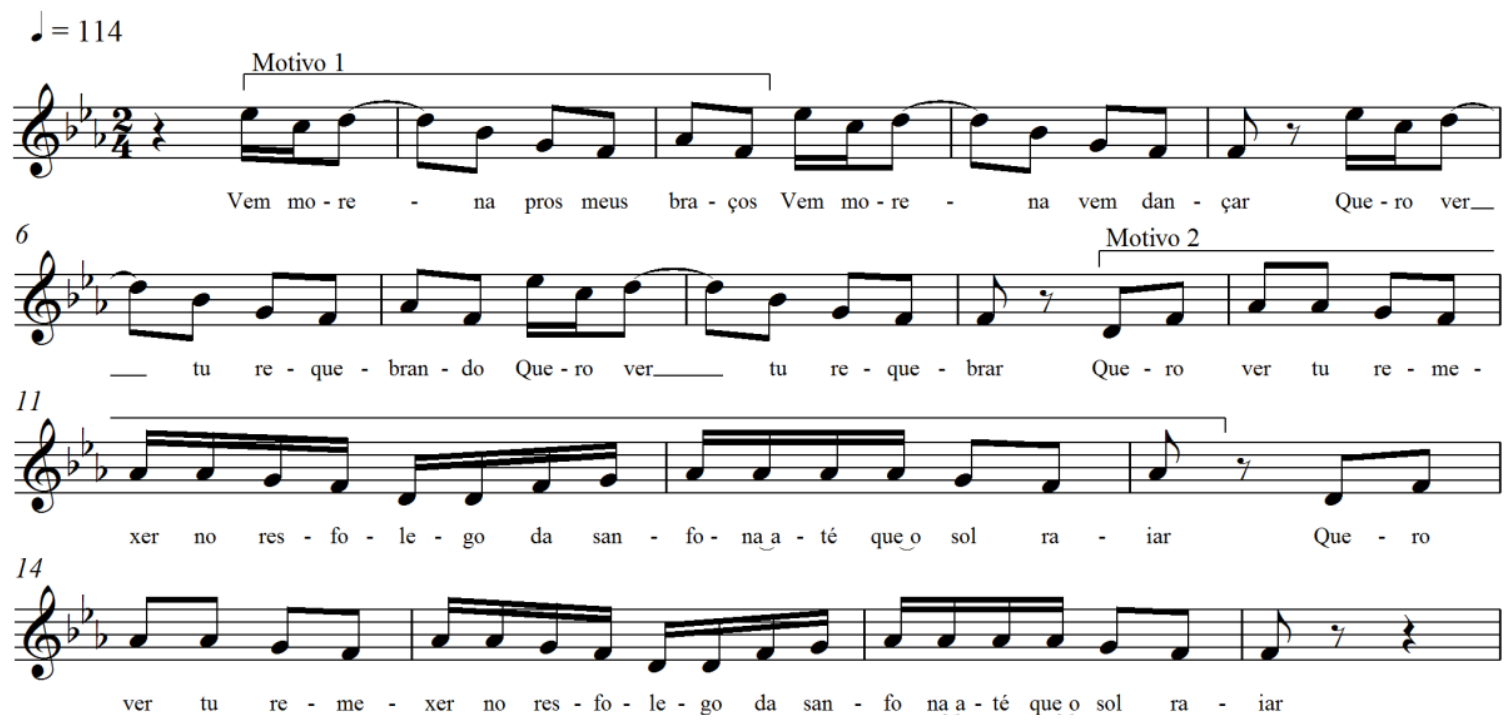

Figura 2.1-1: Vem Morena (Luiz Gonzaga/Zé Dantas) [Faixa 41] 
Verificamos a fisionomia mais musical de Vem morena na própria constituição das melodias imbuídas de certo caráter instrumental. Aqui, não há espaço para maiores resíduos da linguagem oral que possam atrapalhar a regularidade da frase. Obviamente, podemos identificar algumas relações com os elementos entoativos estudados no capítulo anterior, como, por exemplo, a descendência asseverativa de alguém que convida enfaticamente: "vem morena vem dançar". Entretanto, nessa canção, é a melodia que estabelece o texto e não o contrário (como observamos em Jorge Ben Jor). O apelo à dança é muito evidente. Assinalamos na figura acima dois motivos melódicos. Ambos têm como característica essencial a marcação rítmica acentuada e a repetição. Dessa forma, não é apenas o conteúdo da letra que indica um convite ao bailado. A melodia já é em si o próprio bailado. Cria-se então uma forte identidade entre a linha melódica cantada, o texto e a dança. Segundo Luiz Tatit, esse é um fenômeno muitas vezes presente nas canções que fazem da tematização o seu processo de conjugar letra e música. No caso de Luiz Gonzaga, o autor assinala um tipo de composição praticado pelo artista denominado "baião exaltação" no qual os estímulos corporais deflagrados pela canção têm relação estreita com o seu tema. ${ }^{51}$ Esse procedimento, no entanto, não se restringe apenas à celebração do gênero musical, podendo ser aplicado a muitos outros conteúdos.

Enfim, a tendência à tematização, tanto melódica como linguística, satisfaz as necessidades gerais de materialização (linguístico-melódica) de uma ideia. Cria-se, então, uma relação motivada entre tal ideia (natureza, baiana, samba, malandro) e o tema melódico erigido pela reiteração (TATIT, 2002:23)

O mesmo autor destaca então alguns exemplos da tematização linguística e melódica através da qual o cancionista pode retratar personagens de sua cultura ( $O$ que é que a baiana tem?), sua nação (Aquarela do Brasil e Brasil Pandeiro) ou gêneros musicais (Samba da minha terra e Baião) ${ }^{52}$. Cita como possível exemplo desse mesmo processo a canção Águas de Março de Tom Jobim, por exaltar a natureza. Examinando um pouco mais a sua temática, observamos a combinação de elementos diversificados do mundo natural e cultural, positivos e negativos ("festa da cumeeira" e "tombo da ribanceira") ou simples e complexos ("o carro enguiçado" e "o mistério profundo"). Todos esses aspectos, tão variados e até mesmo antagônicos, compõem o retrato da 
existência do sujeito, uma representação cuja força decorre justamente da inclusão dessa complexidade. Temos aqui uma ideia a ser materializada. Vejamos então alguns aspectos do procedimento tematizante nessa canção.

É pau, é pedra

É o fim do caminho

É um resto de toco

É um pouco sozinho

É um caco de vidro, é a vida, é o sol

É a noite, é a morte

É o laço, é o anzol

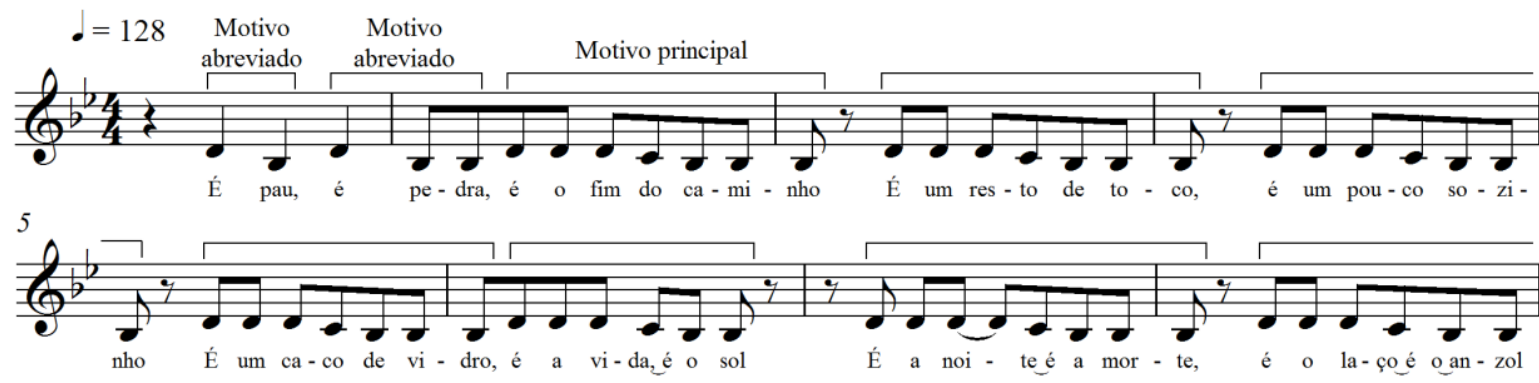

Figura 2.1-2: Águas de Março (Tom Jobim) [Faixa 42]

Observamos nessa canção uma forte reiteração musical. O motivo recorrente, denominado "motivo principal", está assinalado no segundo compasso do fragmento. Podemos considerá-lo como o tema da canção, formado pela sequência de notas Ré-RéRé-Dó-Sib-Sib-Sib que recobre os versos "é o fim do caminho" e "é um resto de toco", por exemplo. Notamos que esse tema aparece de forma abreviada no início da canção, com as frases “É pau” (Ré-Sib) e "É pedra” (Ré-Sib-Sib). O padrão repetido a partir daí, nada mais é do que a extensão dessas frases iniciais, aumentando a quantidade de sílabas e incluindo uma nota de passagem (Dó) entre o Ré e o Sib.

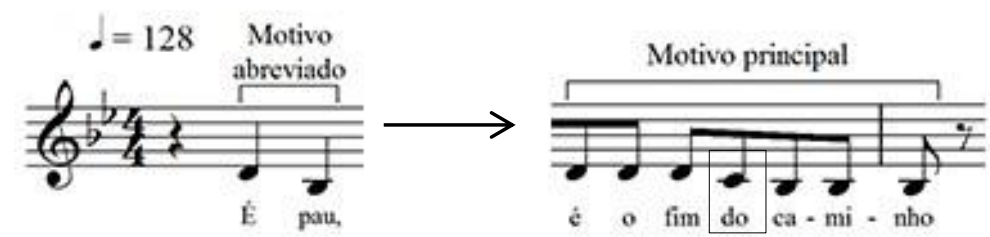

Figura 2.1-3: Desenvolvimento motívico em Águas de Março.

Algumas variações muito sutis podem ocorrer. Por exemplo, a ausência da última nota Sib em finais de frases com palavras oxítonas (“é a vida, é o sol”), o que, no 
entanto, não representa uma quebra significativa em relação ao padrão melódico-rítmico vigente. Nesse verso, aliás, há também uma mudança rítmica muito sutil. Na versão interpretada por Tom Jobim e Elis Regina, ao invés de começar no segundo tempo do compasso, como ocorre com a maioria dos versos, a frase “é a vida, é o sol” tem seu início adiantado para a segunda colcheia do primeiro tempo, fazendo com que termine antecipadamente no quarto tempo e não no começo do compasso seguinte. Essa antecipação rítmica é a razão pela qual a frase seguinte ("É a noite é a morte") também tem seu início adiantado. Observamos que essa antecipação é compensada pelo prolongamento da primeira sílaba da palavra "noite". Assim, a palavra final do verso ("morte") volta a ocupar o lugar estabelecido pelo padrão (terminação da frase no início do compasso seguinte). Esses exemplos, no entanto, são variações mínimas do perfil melódico e não são suficientes para abalar a forma tematizante que predomina nessa composição. Enfim, notamos que a reiteração motívica evidencia mais o plano musical da canção do que sua força entoativa, que tampouco deixa de estar presente. Essa repetição liga-se de maneira eficaz com o conteúdo da letra de Águas de março. Afinal, se ao representar a existência complexa do sujeito, todos os elementos do mundo natural e não natural são equivalentes em importância, logo, nada mais adequado do que recobri-los com o mesmo padrão melódico-rítmico ${ }^{53}$.

Nas canções guiadas pela tematização geralmente observamos um estado de conjunção entre sujeito e objeto. A ideia de continuidade sugerida pela repetição dos motivos musicais é aproveitada pelo cancionista que, intuitivamente, cria para a melodia uma letra de conteúdo eufórico no qual a relação entre os dois actantes é igualmente contínua, harmônica. Nesse sentido, são ilustrativas as canções com refrãos muito reiterados pelo cantor. O refrão é a tradução prefeita desse estado juntivo. Em Do Leme ao Pontal de Tim Maia, por exemplo, o sujeito se apresenta em absoluta conjunção com seu objeto (certas belezas e bens naturais de seu país). O teor conjuntivo é tão forte que a canção é formada por dois refrãos, não havendo nenhuma outra parte musical além deles. O primeiro (figura 2.1-4) é repetido 12 vezes ao longo da faixa. E o segundo (figura 2.1-5) se repete 18 vezes. Essa reiteração exaustiva colabora para a celebração

\footnotetext{
${ }^{53}$ É claro que esse processo não ocorre de forma consciente e tampouco é o objetivo explícito do cancionista. Além disso, não ignoramos a existência de muitos outros fatores ligados à criação da obra (musicais, sociais, etc.). No entanto, é necessário pontuar que, instintivamente, o compositor constrói a relação entre a melodia e a letra da canção criando uma forma melódica que condiz com o conteúdo do texto poético.
} 
desse lugar específico da cidade do Rio de Janeiro bem como enfatiza a relação harmoniosa entre o sujeito e esse local.

Do Leme ao Pontal

Não há nada igual

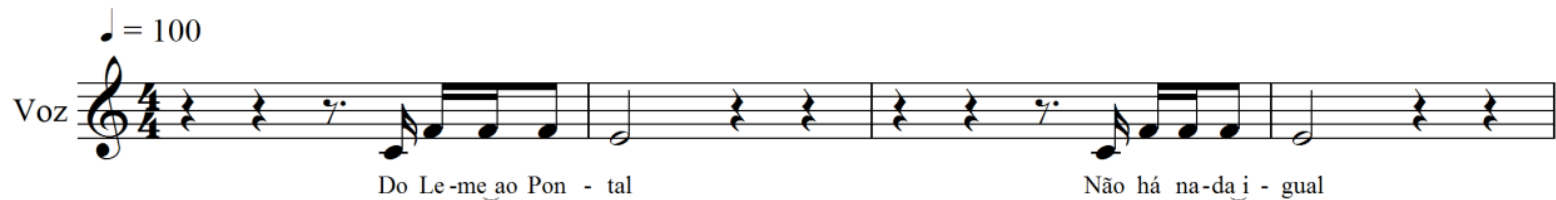

Figura 2.1-4: Primeiro refrão de Do Leme ao Pontal (Tim Maia) [Faixa 43]

Tomo guaraná

Suco de caju

Goiabada para a sobremesa

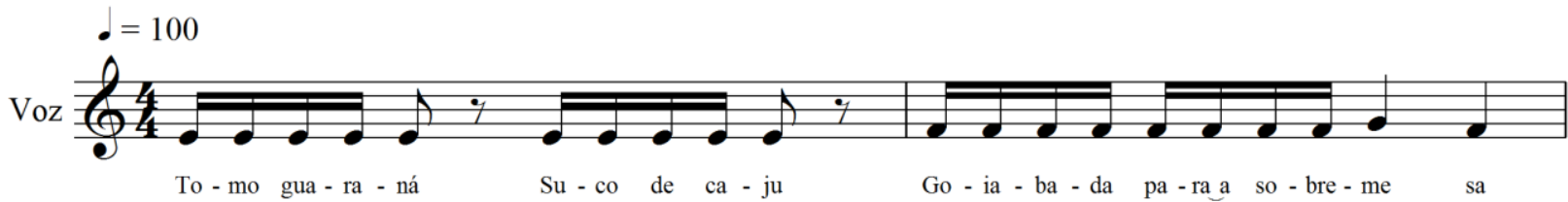

Figura 2.1-5: Segundo refrão de Do Leme ao Pontal [Faixa 44]

Observamos não apenas a repetição exaustiva desses dois refrãos ao longo da obra. Notamos também que a formação interna de cada um deles já em si reiterativa. Como verificamos na figura 2.1-4, a melodia que recobre o verso "Do Leme ao Pontal" é exatamente a mesma de "Não há nada igual". Da mesma forma, na figura 2.1-5, com as frases "Tomo guaraná" e "suco de caju". O importante é notarmos que essa identidade constatada no plano da expressão musical é também encontrada no plano do conteúdo, pois ambas, guaraná e suco de caju, são bebidas produzidas com frutos genuinamente brasileiros. Assim, há uma união entre os motivos melódicos e esses itens da natureza brasileira, todos muito valorizados pela letra: o litoral carioca, as bebidas e a goiabada. A ideia de harmonia completa entre o sujeito e o objeto é ainda enfatizada na canção por seu final em fade out, terminando com a diminuição gradativa da intensidade. Não há corte abrupto. Dessa maneira, fica a sugestão de que a repetição do refrão pode se dar infinitamente, já que sua força conjuntiva parece igualmente perene. 


\subsection{A tematização no rap}

Primeiramente, devemos constatar que os estudos etimológicos comentados no primeiro capítulo também sugerem a presença da tematização. Por exemplo, um dos significados mais difundidos aplicados à palavra rap, rhythm and poetry, já nos indica a importância do aspecto rítmico que, como vimos acima, é característica fundamental do processo temático. Além disso, a etimologia ligada aos concursos verbais nos quais o vocábulo rap ganha o sentido de "bater" ou "criticar" igualmente nos mostra certo caráter tematizante. O jogo verbal the dozens, por exemplo, é uma brincadeira na qual os participantes provocam-se mutuamente por meio de insultos que, no entanto, devem ser rimados, isto é, submetidos a um mínimo de musicalização. Assim, percebemos que além do teor figurativo há igualmente um componente de tematização: o vencedor é o jogador capaz de realizar os maiores feitos sonoros com a língua, ou seja, aquele que consegue desenvolver rimas e jogos rítmicos que produzem algum tipo de encantamento. Logo, a reiteração sonora, tematizante, também contribui para a superação de seu adversário. Assim como os repentistas nordestinos (também sempre comparados aos cantores de rap) que derrotam seus oponentes na medida em que encontram rimas ou outras semelhanças sonoras entre os vocábulos e fazem uma disposição rítmica que soa interessante aos ouvidos do público. Geralmente, quando os acentos da frase verbal coincidem com a acentuação musical da melodia, essa convergência sonora produz um resultado agradável aos ouvintes.

A origem da expressão "hip hop" também está ligada à dança, componente importante das canções temáticas, como pudemos observar em Vem morena, de Luiz Gonzaga, comentada no início desse capítulo. O termo, como assinala Teperman, poderia ser traduzido como "mexer os quadris".

\footnotetext{
Em um desses improvisos, o DJ e MC Lovebug Starski teria criado uma espécie de refrão: "hip hop you don’t stop that makes your body rock" (quadril, salto, não pare, isso faz seu corpo balançar). Associar a palavra hip (quadril) à palavra hop (pular ou dançar), era uma maneira graciosa de dizer: não pare de mexer os quadris, não pare de dançar. A expressão hip hop dava o recado, e soava bem (TEPERMAN) ${ }^{54}$.
}

\footnotetext{
54 TEPERMAN, Ricardo. Se liga no som - as transformações do rap no Brasil. São Paulo, ClaroEnigma, no prelo.
} 
A presença da dança no rap é um assunto interessante para esta pesquisa. Como comentamos anteriormente, o break constitui um dos quatro pilares da cultura hip hop (além do canto do MC, da música do DJ e da arte visual do grafiteiro). Essa dança surgiu como expressão corporal baseada na música praticada pelos imigrantes jamaicanos no bairro do Bronx, em Nova Iorque, no início dos anos 1970. Os dançarinos, ao inventarem movimentos coreografados para o novo gênero musical que surgia, são então chamados de break boys (ou b-boys), pois seu bailado continha muitas pausas e descontinuidades (o vocábulo break no inglês significa "fratura", "intervalo" ou "interrupção"). Assim, no exato momento em que a música rap nascia, aparecia também a sua dança, como se fossem manifestações artísticas complementares.

Além disso, precisamos lembrar que os acompanhamentos criados pelos DJ's são baseados em fragmentos de músicas de gênero dançante, como o soul, o funk e a disco music. Essa prática ocorre desde o nascimento do gênero. Por exemplo, a canção Rapper's Delight, lançada em 1979 pelo trio norte-americano Sugarhill Gang, é considerada como o primeiro rap a alcançar grande sucesso e popularizar o gênero musical internacionalmente. A sua base foi construída a partir do arranjo instrumental de Good Times do grupo Chic, um sucesso da disco music no final da década de $1970^{55}$. Essa prática ligada à colagem de excertos sonoros de outros autores é uma das principais características musicais do rap e faz parte da formação artística do DJ. Assim, no rap, dificilmente há o agrupamento de músicos instrumentistas para a realização do arranjo, ficando a cargo do DJ selecionar os trechos musicais já gravados e compor a base a partir do repertório dançante da música negra com o qual ele possuía maior intimidade.

Como a maioria dos rappers começou com um DJ tocando discos para o acompanhamento musical (sem músicos tocando ao vivo), muitas gravações de rap são baseadas em acordes e linhas de baixo de canções conhecidas (TOOP, 2000: 17) (56 $^{56}$

Como vimos anteriormente, há no rap uma problematização em relação à presença da dança. Afinal, qual o seu papel e, por conseguinte, qual a função da tematização para o gênero? Primeiramente, devemos considerar que a dança pode

\footnotetext{
${ }^{55}$ Ver: TOOP, 2000:16

${ }^{56}$ Because most rappers started out with a DJ playing records for musical accompaniment (no live musicians), many rap records are based around the chords and bass lines of popular songs (TOOP, 2000: 17)
} 
assumir diferentes significados culturais. No rap, ao que tudo indica, ela não está associada somente a um contexto de diversão e lazer. Aqui, os movimentos corporais podem estar carregados de agressividade. A dança dos b-boys ou do público que comparece a um show de rap parece ser reflexo direto do entendimento da mensagem do texto. Muitas vezes, é a tradução gestual dessa mensagem. No final do primeiro capítulo, destacamos uma passagem de Walter Garcia na qual o autor comentava sobre o resgate da dignidade e do corpo por meio do balanço gerado pela música dos Racionais MC's. Balanço que favorecia mais a compreensão da letra do que a própria dança. $\mathrm{O}$ estudioso ainda ressaltava que se não podemos dizer que a dança é essencial nas apresentações do grupo, também não podemos deixar de notar que o público "canta junto, dramatiza a letra e balança o corpo" (GARCIA, 2007:186). Trata-se, talvez, de uma manifestação corporal peculiar, uma dança incomum. Maria Rita Kehl em seu texto “A fratria órfã: o esforço civilizatório do RAP na periferia de São Paulo" já notara essa característica do público de rap, “executando a dança que não autoriza alegria nenhuma, sensualidade nenhuma" (KEHL, 2000: 209-210). Assim, no rap, o processo tematizante carrega essa tensão: se, por um lado, há uma reiteração rítmica que convida à dança e sugere valores eufóricos, por outro, o conteúdo disjuntivo de grande parte das letras não permite que o sentimento de felicidade plena prevaleça.

Após essa breve consideração sobre a presença da dança no rap, precisamos investigar de que forma a tematização atua na esfera musical propriamente dita. Para isso, vamos separar essa análise em duas etapas. Primeiramente, abordaremos o processo temático no acompanhamento instrumental e, posteriormente, na melodia do canto. No que se refere à base do DJ, ainda que observemos essa questão problemática em relação à dança, notamos que seu valor puramente musical é também um fator importante para a conquista do ouvinte. Ou seja, somente o canto do MC não basta para mobilizar o público.

\footnotetext{
Aliás, as síncopes da batida percussiva e dos instrumentos melódico-harmônicos, junto dos efeitos sonoros, precisam agradar. O balanço, logicamente, é fundamental em se tratando de rap (GARCIA, 2007: 196)
}

O rap configura-se então como um gênero de canção cujo teor musical também é relevante e está predominantemente ligado ao ritmo. Nas técnicas inventadas pelos artistas desde o nascimento do gênero já podemos constatar essa proeminência do fator 
rítmico. O músico Kool Herc, um dos pioneiros do hip hop e organizador das primeiras festas do Bronx, é tido como o inventor de um procedimento composicional muito difundido entre os DJ's, o chamado breakbeat. Trata-se da repetição de um fragmento musical de uma canção já gravada. Com dois toca-discos executando o mesmo LP, o DJ seleciona o trecho de seu interesse (geralmente uma base instrumental com bateria, contrabaixo e guitarra elétrica) e após tocá-lo uma vez volta o disco para o ponto inicial e repete o mesmo fragmento. Essa técnica é também conhecida como backspin ou back to back $^{57}$. Dessa maneira, cria-se um novo acompanhamento, uma base musical cíclica sobre a qual os MC's cantam suas letras. Outro artifício muito utilizado chama-se scratch, técnica na qual o DJ arranha o disco de vinil com a agulha da vitrola para produzir determinadas frases rítmicas. Vejamos alguns exemplos dessas bases rítmicas em canções brasileiras.

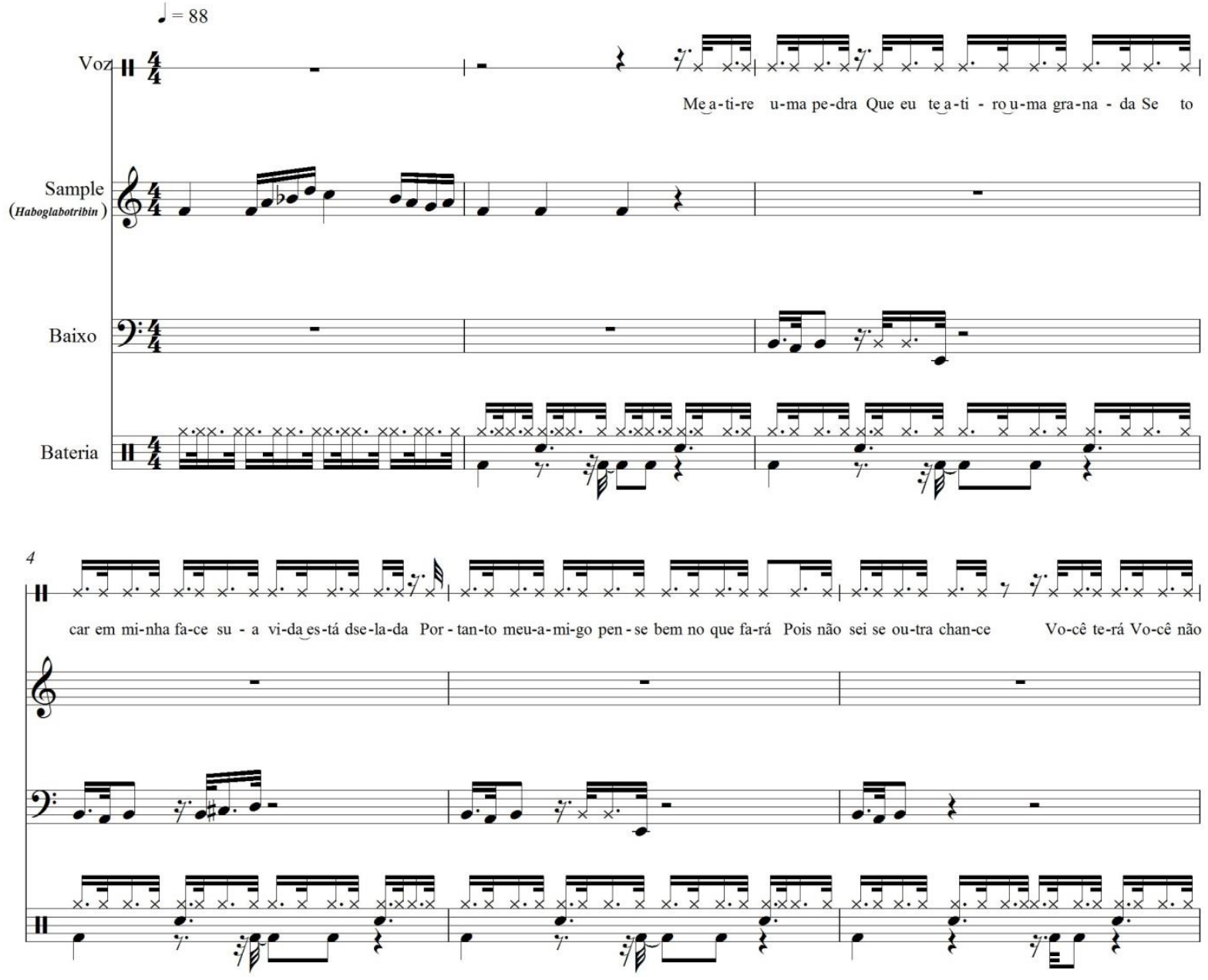

Figura 2.2-1: Corpo Fechado (Thaíde e DJ Hum) In: Hip hop Cultura de Rua (1988) [Faixa 45]

57 Ver TEPERMAN, Ricardo. Se liga no som - as transformações do rap no Brasil. São Paulo, ClaroEnigma, no prelo. 


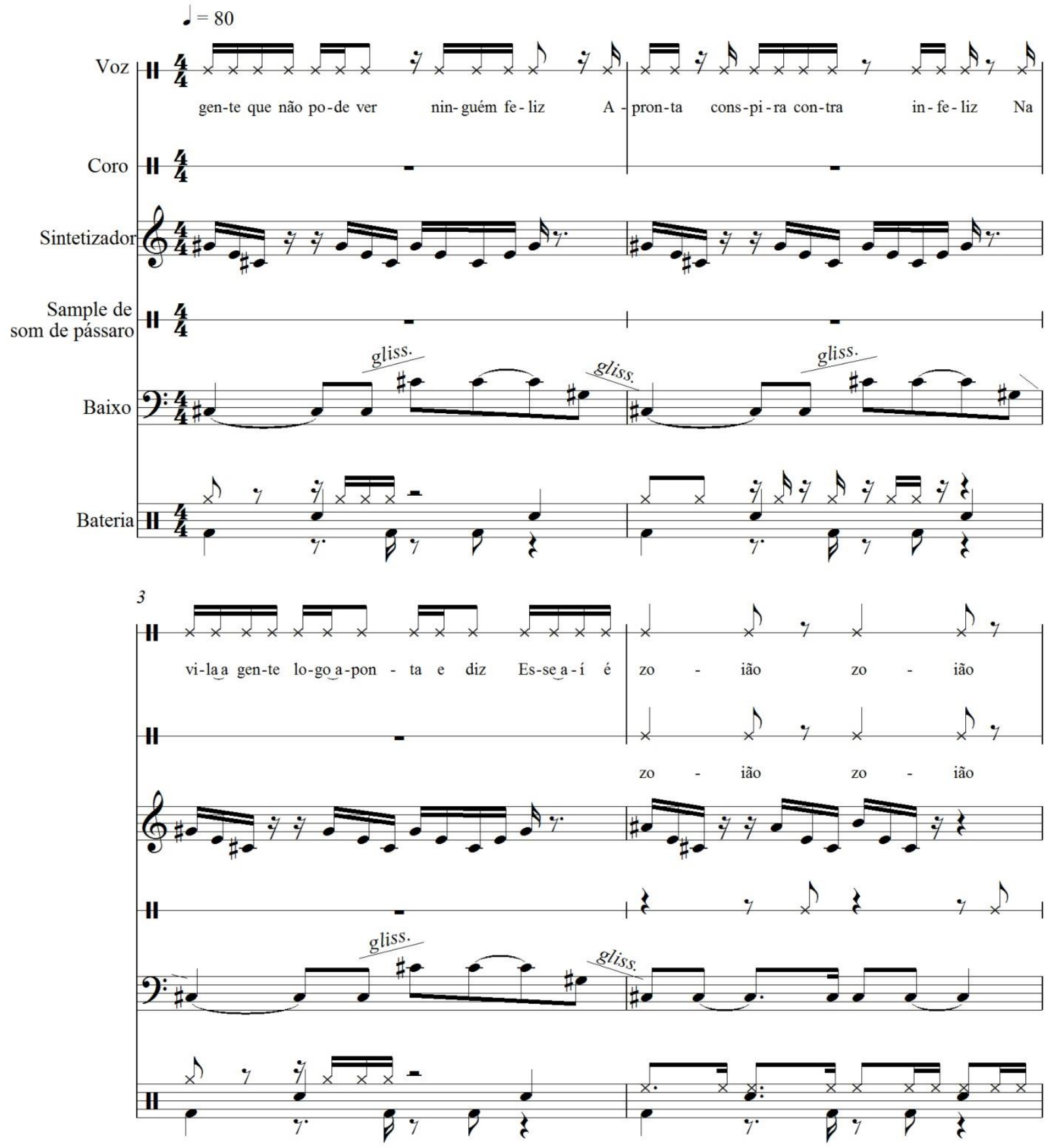

Figura 2.2-2: Zoião (Emicida) In: O Glorioso Retorno de Quem Nunca Esteve Aqui (2013) [Faixa 46] 

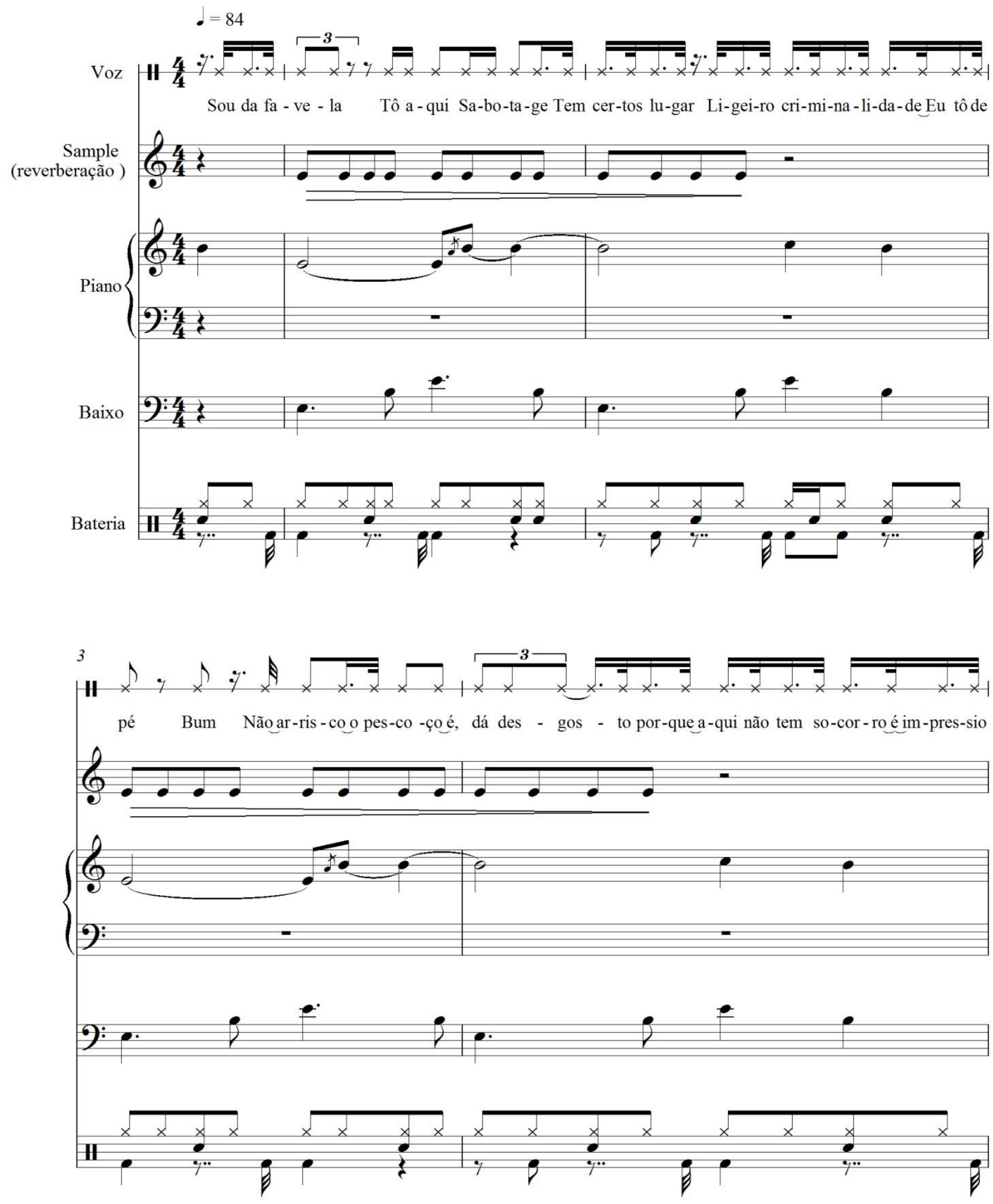

Figura 2.2-3: Respeito é pra quem tem (Sabotage) In: Rap é compromisso (1999) [Faixa 47] 


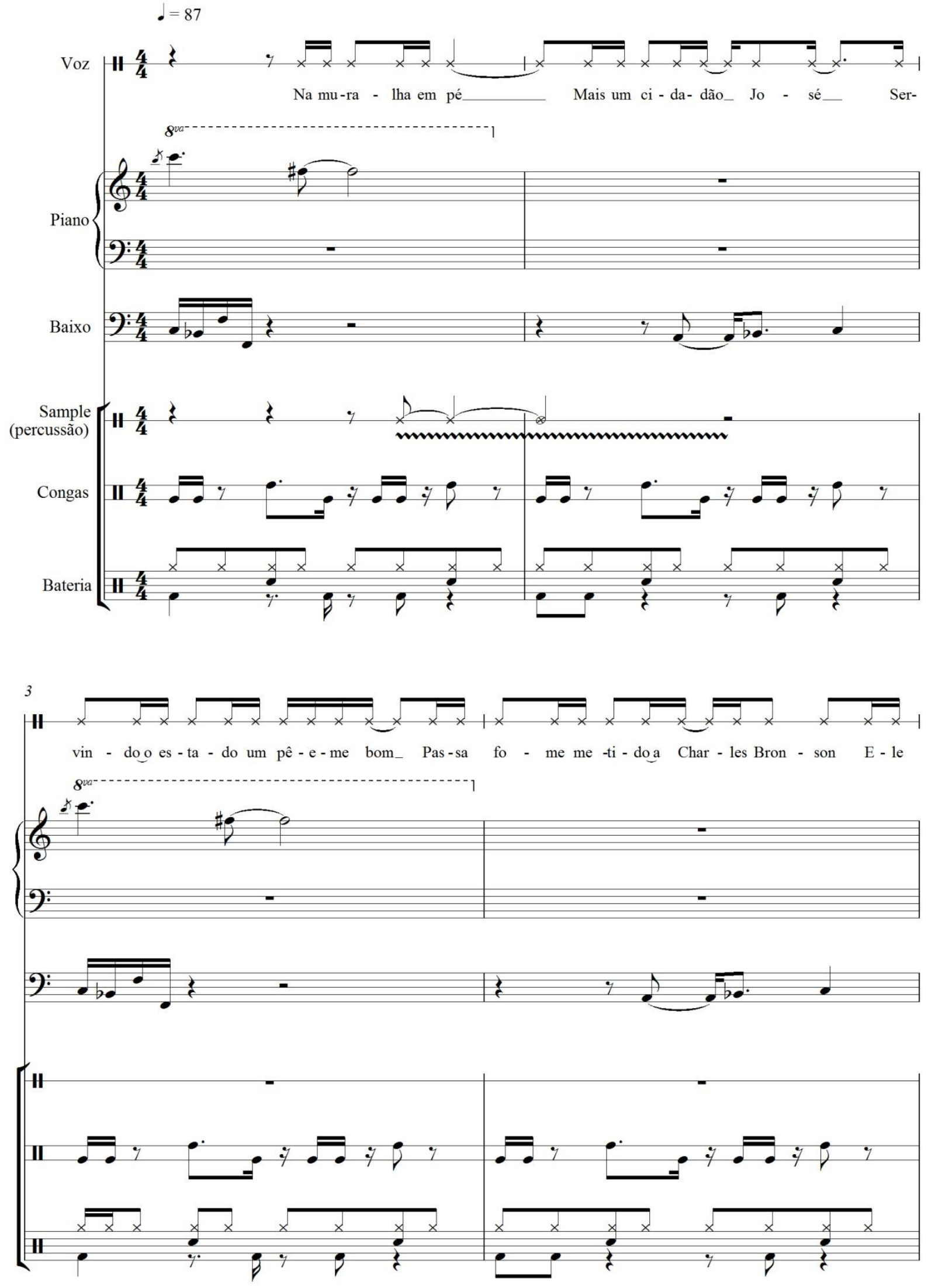

Figura 2.2-4: Diário de um detento (Racionais MC's) In: Sobrevivendo no inferno (1998) [Faixa 48] 
Para tentarmos traçar um perfil mais geral das bases de rap, selecionamos exemplos bem diversificados. Corpo Fechado de Thaíde e DJ Hum é a primeira faixa da primeira coletânea de rap lançada no Brasil, o LP Hip hop cultura de rua, de 1988. Zoião faz parte no último disco do rapper Emicida, um dos mais novos talentos do gênero no Brasil. Respeito é pra quem tem e Diário de um detento, de Sabotage e Racionais MC's respectivamente, são canções que foram lançadas no final dos anos 1990. Observamos muitas semelhanças entre esses quatro fragmentos musicais, tanto na instrumentação, quanto na composição do arranjo. Em todos eles há uma voz cantada sobre uma base de bateria, baixo e a presença de uma ou duas linhas instrumentais que indicamos nas partituras como um piano (Diário de um detento e Respeito é pra quem tem), um sintetizador (Zoião) e um sample (Corpo fechado) ${ }^{58}$. Além da semelhança na instrumentação, constatamos que o seu uso musical é praticamente o mesmo nos quatro exemplos. A bateria possui sempre três vozes. O bumbo predominantemente ataca no primeiro e no contratempo do terceiro tempo do compasso. A caixa sempre ataca no segundo e no quarto tempo. E o chimbal subdivide cada pulsação binariamente (geralmente em duas partes, mas às vezes com quatro ataques, como no caso de Corpo fechado). Certamente, essa configuração rítmica dos tambores e pratos da bateria é influência direta da soul music norte americana. Os exemplos abaixo foram extraídos de duas canções de James Brown, Funky President (People It's Bad) e Papa Don't Take No Mess. Ambas, até foram usadas pelos Racionais MC's como samples das suas canções Mulheres vulgares e Tempos difíceis, respectivamente.

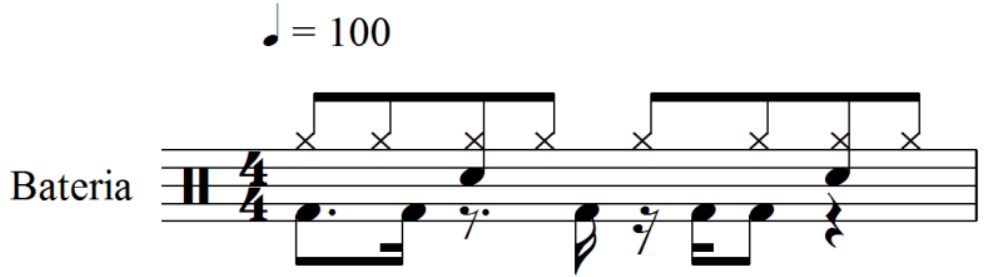

Figura 2.2-5: Funky President (People It's Bad) (James Brown) [Faixa 49]

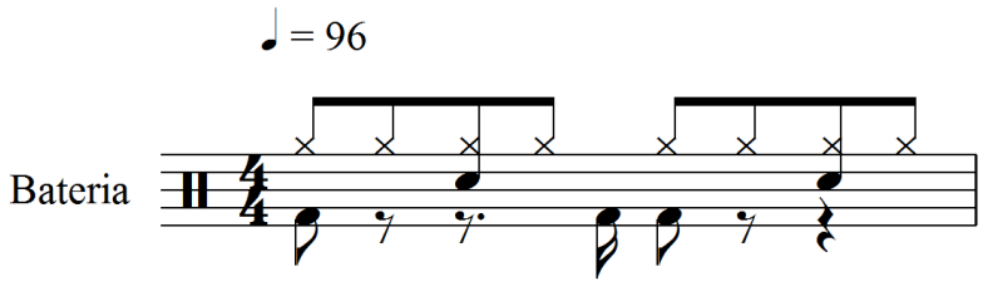

Figura 2.2-6: Papa Don't Take No Mess (James Brown) [Faixa 50]

58 Trata-se de um trecho da canção Haboglabotribin de Bernard Wright, com bpm original de 100 batimentos por minuto, e que na faixa de Thaíde e DJ Hum foi diminuído para 88. 
Observamos acima uma significativa semelhança rítmica em relação às bases instrumentais de Corpo fechado, Zoião, Respeito é pra quem tem e Diário de um detento. O chimbal também divide a pulsação em duas colcheias (voz superior das duas figuras acima), a caixa ataca no segundo e quarto tempos (terceiro espaço do pentagrama) e o bumbo varia (ora ataca nos tempos um e três, como na figura 2.2-6, ora ataca no primeiro e no contratempo do terceiro tempo, como na figura 2.2-5). O mais importante, no entanto, é notarmos o caráter cíclico das construções rítmicas, tanto em raps constituídos por samples dos DJ's quanto em raps tocados por um grupo de instrumentistas. Nos quatro exemplos dos MC's brasileiros, percebemos nitidamente a circularidade dos eventos musicais. Em Diário de um detento, por exemplo, o padrão rítmico da bateria se repete de dois em dois compassos, o ritmo das congas possui padrão de um compasso, o sample de percussão ocorre a cada quatro e o baixo e o piano se repetem a cada dois. Isto é, temos ciclos rítmicos de um, dois ou quatro compassos. Essa é uma das funções atribuídas ao DJ: configurar os padrões rítmicos de cada instrumento e decidir a periodicidade de cada padrão (depois de quanto tempo um mesmo desenho rítmico irá se repetir).

É interessante perceber que as características de tematização presentes no rap podem ocorrer por influência das canções do repertório da soul music ${ }^{59}$. Isso acontece de maneira explícita nas apropriações realizadas pelos DJ's para a composição de seus samples. Por exemplo, constatamos esse tipo de procedimento em grande parte das canções dos Racionais MC's nas quais trechos de fonogramas dos principais artistas da soul music norte-americana foram utilizados. Cantores e grupos como The Isley Brothers, Al Green, Curtis Mayfield, Marvin Gaye, Isaac Hayes, James Brown, Edwin Starr e artistas brasileiros como Jorge Ben, Tim Maia e Cassiano aparecem com frequência nas faixas do grupo ${ }^{60}$. Como vimos no capítulo anterior, ao realizar tal

\footnotetext{
${ }^{59}$ Estudaremos esse assunto de maneira mais detida no capítulo seguinte, dedicado à passionalização no rap.

60 Em Mágico de Oz (1998), há a base instrumental acelerada da música It's Too Late de The Isley Brothers. Em De Volta À Cena (2002), ouvimos partes instrumentais da canção Simply Beautiful de Al Green também acelerada pelo DJ. De Curtis Mayfield, temos a base de Freddie's Dead presente no rap Mano na porta do bar (1993). Main Theme From Trouble Man de Marvin Gaye é usada em Fio da navalha (1993) com o andamento bastante acelerado. De Isaac Hayes temos um pequeno trecho da parte instrumental de Hyperbolicsyllabicsesquedalymistic usado em Rapaz Comum (1998), com andamento desacelerado. Em Pânico na zona sul (1990), temos trechos instrumentais de Mind Power de James Brown. Em Diário de um detento (1998), escutamos as percussões da música Easin' In de Edwin Starr. De Jorge Ben temos trechos cantados por ele em Frases e Domingaz inseridos na canção Fim de semana no parque (1993). Compassos do arranjo instrumental de Ela Partiu, de Tim Maia, estão presentes em Homem na estrada (1993). De Cassiano, ouvimos a introdução da faixa Uma lágrima, repetida por toda a canção Sou + Você (2002).
} 
apropriação o DJ pode aumentar ou diminuir a velocidade da pulsação da música original. KL Jay, ao utilizar um trecho da canção Hyperbolicsyllabicsesquedalymistic de Isaac Hayes em Rapaz Comum (1998), diminuiu significativamente o seu andamento. Essa alteração foi tão acentuada que podemos até mesmo reconhecer a alteração da frequência em certos instrumentos da base como, por exemplo, o piano, que se torna mais grave na versão dos Racionais MC's. Portanto, essa prática das apropriações realizadas pelos DJ's explicita ainda mais a relação íntima entre os padrões musicais tematizantes da soul music e a música do rap, relação também exemplificada aqui a partir da semelhança entre a linha instrumental da bateria de canções de James Brown (figuras 2.2-5 e 2.2-6) e o arranjo instrumental de raps brasileiros.

Além disso, é importante ressaltarmos que a construção musical do acompanhamento está em constante diálogo com a expressão da letra do rap. Como observamos acima, o fundo musical sobre o qual o MC canta é sempre marcado pela repetição de motivos melódicos e percussivos. No entanto, há certas variações realizadas pelos DJ's que transformam significativamente essa base instrumental. A canção Negro Drama, por exemplo, ilustra bem esse tipo de procedimento. Examinemos a configuração sonora de seu arranjo:

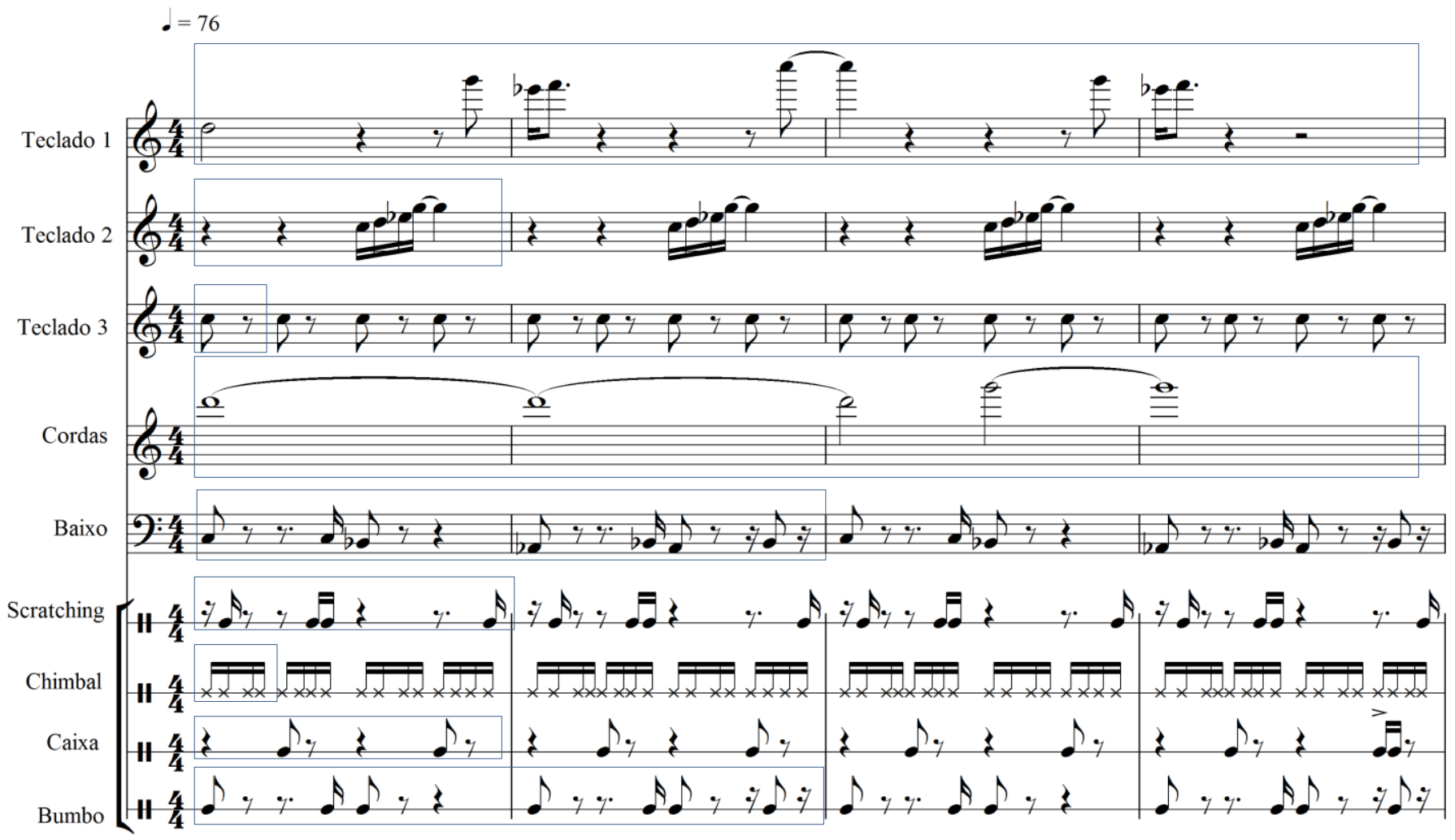

Figura 2.2-7: Acompanhamento instrumental de Negro Drama (Racionais MC's) [Faixa 51] 
No arranjo da base, o padrão que se repete é formado por quatro compassos quaternários nos quais atuam nove vozes instrumentais: teclados 1, 2 e 3, cordas, baixo, scratching, chimbal, caixa e bumbo ${ }^{61}$. Cada instrumento, no entanto, apresenta padrões sonoros específicos cuja periodicidade também varia. Na figura acima, assinalamos em cada linha instrumental a duração desses desenhos rítmicos que são repetidos. No teclado 1 e nas cordas o motivo dura quatro compassos. No baixo e no bumbo dura dois. No teclado 2, no scratching e na caixa há um padrão de um compasso. Por fim, no teclado 3 e no chimbal notamos que o ritmo repetido corresponde a somente uma unidade de tempo. Portanto, quando esses instrumentos atuam simultaneamente, observamos que o padrão musical do acompanhamento volta a se repetir somente após quatro compassos. A conformação desse padrão fundamenta, num primeiro momento, a disposição rítmica do canto do MC. Mas o trabalho do DJ não se restringe apenas a essa disposição sonora reiterativa da base. No decorrer da canção ele pode alterar certos elementos desse arranjo, geralmente por meio da eliminação de algum trecho instrumental, a partir da sua sensibilidade em relação ao conteúdo da letra ou ao modo como ela é cantada pelos outros rappers. Como observou Walter Garcia, tendo em vista o alto grau de reiteração dessas construções musicais, a simples supressão de alguma dessas vozes torna-se um recurso muito significativo.

um ou outro elemento do fundo musical desaparece em algumas passagens, atraindo a atenção do ouvinte, mais ou menos como fazem tevê e rádio quando ficam mudos. Ou seja, a atenção é despertada pelo esvaziamento, não pelo acréscimo (GARCIA, 2007: 198)

Assim, ao longo da canção, pequenas passagens de alguns instrumentos são suprimidas com o objetivo de sublinhar certas palavras, transições ou terminações. Negro drama apresenta oito momentos em que algum trecho musical do acompanhamento é eliminado. Na tabela abaixo, a ausência momentânea de alguma de suas vozes instrumentais está indicada pelo espaço em branco.

\footnotetext{
${ }^{61}$ Para facilitar a análise, separamos as vozes da bateria em pautas diferentes.
} 


\begin{tabular}{|c|c|c|c|c|c|c|c|c|c|c|}
\hline & & \multicolumn{9}{|c|}{ INSTRUMENTOS } \\
\hline TEMPO & TRECHO DA LETRA & 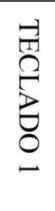 & 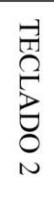 & 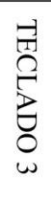 & $\begin{array}{l}\underset{\sigma}{\sigma} \\
\underset{\infty}{\overrightarrow{0}}\end{array}$ & 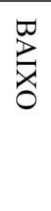 & 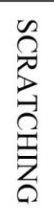 & 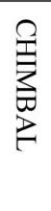 & 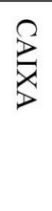 & 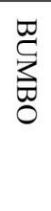 \\
\hline 0'59'” & Você deve tá pensando o que você tem a ver com isso & & & & & & & & & \\
\hline $2 ' 12^{\prime \prime}$ & Sempre a provar que sou homem não um covarde & & & & & & & & & \\
\hline $2^{\prime} 26^{\prime}$ & Guerreiro, poeta, entre o tempo e a memória, ora & & & & & & & & & \\
\hline $2^{\prime} 49^{\prime}$ & Vi um pretinho, seu caderno era um fuzil & & & & & & & & & \\
\hline 3'39', & $\begin{array}{l}\text { Mãe solteira de um promissor vagabundo } \\
\text { Luz, câmera e ação... }\end{array}$ & & & & & & & & & \\
\hline $4^{\prime} 18^{\prime \prime}$ & Problema como escola eu tenho mil, mil fitas & & & & & & & & & \\
\hline 4’38'” & Seu filho quer ser preto, rá, que ironia & & & & & & & & & \\
\hline $5 ’ 20 \prime$ & Valeu, mãe, negro drama (drama, drama, drama) & & & & & & & & & \\
\hline
\end{tabular}

Figura 2.2-8: Supressões no arranjo instrumental da canção Negro Drama. [Faixa 52]

É importante observar alguns detalhes que demonstram o compromisso dessa organização sonora com a expressão da letra da canção. No verso "Você deve tá pensando o que você tem a ver com isso", a ausência dos teclados 2 e 3, do scratching e da caixa incide justamente sobre a palavra "você" (na segunda vez em que ela aparece na frase). O destaque gerado por essas supressões é significativo, pois ocorre exatamente no primeiro verso em que essa palavra é ouvida na obra. Como veremos no capítulo seguinte, quando analisaremos outros aspectos da mesma canção, esse vocábulo possui especial importância na letra devido à atitude de confronto adotada pelo rapper em relação ao seu interlocutor. Da mesma maneira, a palavra "homem" é sublinhada no verso seguinte, "Sempre a provar que sou homem não um covarde". Em "Guerreiro, poeta, entre o tempo e a memória, ora", o cancelamento da bateria, do scratching e do baixo recai precisamente sobre a palavra "ora" no sentido de valorizar a terminação e a transição sutil que se dá entre esse verso e o seguinte. De forma inteligente, os dois momentos com maior número de supressões são os finais dos últimos versos da primeira e da segunda parte da canção: "Vi um pretinho, seu caderno era um fuzil", com cinco supressões e "Valeu, mãe, negro drama (drama, drama, 
drama)", com sete supressões. Esses versos, que finalizam as partes cantadas por Edy Rock e Mano Brown, respectivamente, estabelecem relações interessantes entre si. No primeiro, uma criança cuja infância foi eliminada aparece amparada por um fuzil. No segundo, um adulto agradece o apoio de sua mãe por ajudá-lo a não seguir o mesmo caminho trilhado por esse menino, "contrariando as estatísticas" "62. O corte do acompanhamento no verso cantado por Mano Brown é substancialmente mais impactante. Aliás, como as cordas se mantêm presentes ao longo de toda a canção, podemos dizer que há nesse ponto a supressão máxima dos elementos musicais do loop e essa anulação valoriza as reverberações da palavra "drama" que ouvimos em seguida. Percebemos então que o trabalho realizado pelo DJ, ainda que puramente musical, permanece atento ao conteúdo da letra e à maneira de entoar do MC.

Além desses apagamentos de trechos instrumentais, há igualmente outros recursos sonoros que podem potencializar a mensagem da letra. Por exemplo, em Negro drama constatamos ao todo nove ocorrências nas quais certas palavras cantadas pelos rappers são repetidas por meio de um efeito de reverberação aplicado pelo DJ. Abaixo, sublinhamos os vocábulos que foram replicados.

[0'12'] negro drama

[1'37'’] glórias

[2'02'] mina fraca

[2'32'’] não mate

[2'50'] fuzil

[2'52'] negro drama

[3'23'’] multidão

[4'38'] Seu filho quer ser preto, rá, que ironia

[5'20'” $\underline{\text { drama }}$

A palavra "drama" tem função especial na obra. Primeiramente, devemos lembrar que ela está no título da canção, sintetizando a questão principal da letra: a discriminação do negro. Além disso, a repetição do vocábulo enfatiza ainda mais essa injustiça social: a reverberação do mesmo drama que se repete de geração a geração. Afinal, "pobre, preso ou morto já é cultural"63. Na repetição da palavra "multidão",

${ }^{62}$ Trecho da canção Capítulo 4, versículo 3. In: Sobrevivendo no inferno (1998)

${ }^{63}$ Trecho da canção Negro drama. In: Nada como um dia após o outro dia (2002) 
observamos algo muito interessante, pois além do eco inserido pelo DJ, o vocábulo já aparece mais de uma vez na própria letra do rap.

Veja, olha outra vez o rosto na multidão

A multidão é um monstro sem rosto e coração

Assim, nesse trecho o ouvinte escuta a palavra "multidão" ao menos cinco vezes e essa reiteração reforça a ideia do tumulto de pessoas que hostiliza as duas personagens. Outro recurso musical utilizado pelo grupo é a duplicação de vozes. Destacamos três momentos em que isso ocorre na canção ${ }^{64}$.

[0'31'"] Sente o drama

[0'36'] negro drama

[1'19'”] Não foi sempre dito que preto não tem vez, e então

Olha o castelo e não foi você quem fez? Cuzão!

Nos dois primeiros casos constatamos que a sobreposição de vozes valoriza a expressão "negro drama", repetida ao longo de toda a canção. "Sente o drama" seria então uma variação dessa mesma expressão. No terceiro caso, notamos uma construção interessante: as terminações em "ão" são reforçadas com o dobramento da voz como forma de preparar e dar maior destaque à emissão da última palavra (“cuzão"), quando se agride explicitamente o interlocutor. Dessa maneira, podemos constatar que há uma relação íntima entre esses fatores musicais (a construção dos padrões do loop, as supressões dos motivos, as repetições em eco de certas palavras, as sobreposições e o uso do sampler) e o conteúdo da letra.

Há um trabalho artístico sofisticado que é, no entanto, obtido de maneira muito natural e intuitiva, característica comum na atividade do cancionista. Essa naturalidade presente na mobilização dos diversos recursos criativos em prol do sentido principal da letra deve-se ao fato de que todos os integrantes do grupo estão inteiramente envolvidos e conscientes em relação à obra e à experiência que ela retrata. Mais uma vez observamos a força política do gênero: a mensagem da canção é tão direta e crucial para os músicos e para as suas comunidades, que o entendimento é geral e todos os elementos ali colocados agem no sentido de reafirmá-la. Assim, o valor da canção rap

${ }^{64}$ Os vocábulos duplicados estão sublinhados. Podemos dizer que essas duplicações trazem também uma significativa carga figurativa (e contestatória) aos exemplos. Sugerindo um coro, elas nos permitem ouvir a voz dos outros indivíduos da comunidade, o que reforça a ideia de uma reivindicação coletiva. 
está ligado não somente à sua construção artística, mas igualmente à atitude dos cancionistas em relação ao seu papel social, se é que podemos separar essas duas esferas. Tratamos desse assunto no primeiro capítulo, quando constatamos que a força da figurativização no rap gera uma aproximação entre os autores e suas obras e entre os autores e o seu público. Na análise acima, ficou evidente que o forte envolvimento com a mensagem também é verificado nas escolhas musicais do arranjo.

Cumprida essa primeira etapa na qual analisamos elementos de tematização no acompanhamento instrumental do rap, podemos agora examinar de que maneira o processo temático atua na construção da melodia do canto. Vejamos. Há, como indica Teperman, uma ligação estreita entre o canto do MC e a base rítmica do DJ. Isto é, os artistas preocupam-se constantemente com o encaixe dos versos no arranjo instrumental.

\begin{abstract}
A primeira lição que rimadores experientes transmitem aos iniciantes, seja de maneira informal, seja nas oficinas de MC trata do padrão rítmico da base sobre a qual serão construídas as rimas, o "bum-clap". A ideia é que a escansão dos versos seja calcada na levada dos breakbeats (no geral tiradas de disco de funk e soul), e construída com bumbo ("bum") no primeiro e terceiro tempos, e caixa ("clap") no segundo e quarto tempos do compasso quaternário. (TEPERMAN) ${ }^{65}$
\end{abstract}

A preocupação em explorar parâmetros de duração ao compor as suas letras já é uma primeira investida musical do MC. De um lado, as sílabas dos versos vão sendo emitidas de acordo com os ataques do acompanhamento instrumental. De outro, o tamanho de cada verso também pode estar subordinado à conformação musical da base, de acordo com o andamento escolhido e a periodicidade com que se repete o loop construído pelo DJ. Essas questões musicais, ainda que elementares, ajudam a estabilizar minimamente a sonoridade do texto verbal, distanciando-o da fala.

Outro recurso sonoro extremamente importante para o rapper é a rima. De certa forma, podemos considerá-la como um artifício musical que também diminui o caráter figurativo da canção. Ou seja, ao buscar semelhanças sonoras entre as palavras, o MC está dando um grau a mais de musicalização ao seu texto. Afinal, em nossa fala cotidiana, geralmente não há a preocupação com a sonoridade dos vocábulos, apenas com o conteúdo a ser transmitido. $\mathrm{O}$ ato de rimar é, ainda que minimamente, um fator

65 TEPERMAN, Ricardo. Se liga no som - as transformações do rap no Brasil. São Paulo, ClaroEnigma, no prelo. 
de ordenação musical que estabiliza o texto verbal. A importância das rimas no universo do hip hop é tão forte que o verbo "rimar" é até mesmo utilizado como sinônimo de "cantar". É interessante que a atividade do MC seja definida como a "arte de rimar", pois demonstra que para grande parte dos ouvintes ele não canta, nem fala: se, por um lado, não estabiliza notas musicais, por outro, seu texto não chega a ser instável como a fala cotidiana.

No primeiro item desse capítulo verificamos que, em canções ligadas ao processo da tematização, é muito frequente a existência de um refrão, marca do estado de conjunção entre sujeito e objeto (momento em que todos os conflitos estão resolvidos). Como vimos, o refrão é um trecho musical que se repete com regularidade dentro da composição. Essa repetição gera um teor de continuidade: o ouvinte identifica elementos sonoros que se repetem criando a sensação de previsibilidade e, consequentemente, de algo contínuo. Essa forma é perfeitamente compatível com o conteúdo conjuntivo, pois, geralmente, quando não encontramos desencontros (ou descontinuidades) na melodia da canção, também não os encontramos no assunto da letra. Nesse sentido, é interessante analisarmos como se dá essa questão no gênero rap, cujo repertório apresenta poucos refrãos. Vejamos. Por um lado, esse tipo de construção musical baseada na repetição se distancia do ímpeto figurativo dos rappers (que adotam o registro falado para transmitirem suas mensagens com maior eficácia). Investir na reiteração de algumas frases é, de certo modo, sair desse registro, pois na língua oral não se costuma usar esse tipo de procedimento. Por outro lado, a ausência do refrão é significativa na medida em que grande parte das letras dos $\mathrm{MC}$ 's possui conteúdo predominantemente disjuntivo. Se o assunto dos versos geralmente se refere à dificuldade do sujeito (população de baixa-renda) de alcançar seu objeto (condições dignas de vida), a forma musical adotada dificilmente será conjuntiva. Há, no entanto, alguns raps que trabalham com refrãos ou reiterações tematizantes. Examinemos esses casos específicos. Por exemplo, há algumas canções nas quais observamos a presença de uma identidade motívica ligada àquela tendência de materialização de uma ideia ou personagem, uma característica típica do processo temático.

Hoje eu sou ladrão, artigo 157

As cachorra me ama

Os playboy se derrete

Hoje eu sou ladrão, artigo 157 
A polícia bola um plano

Sou herói dos pivete

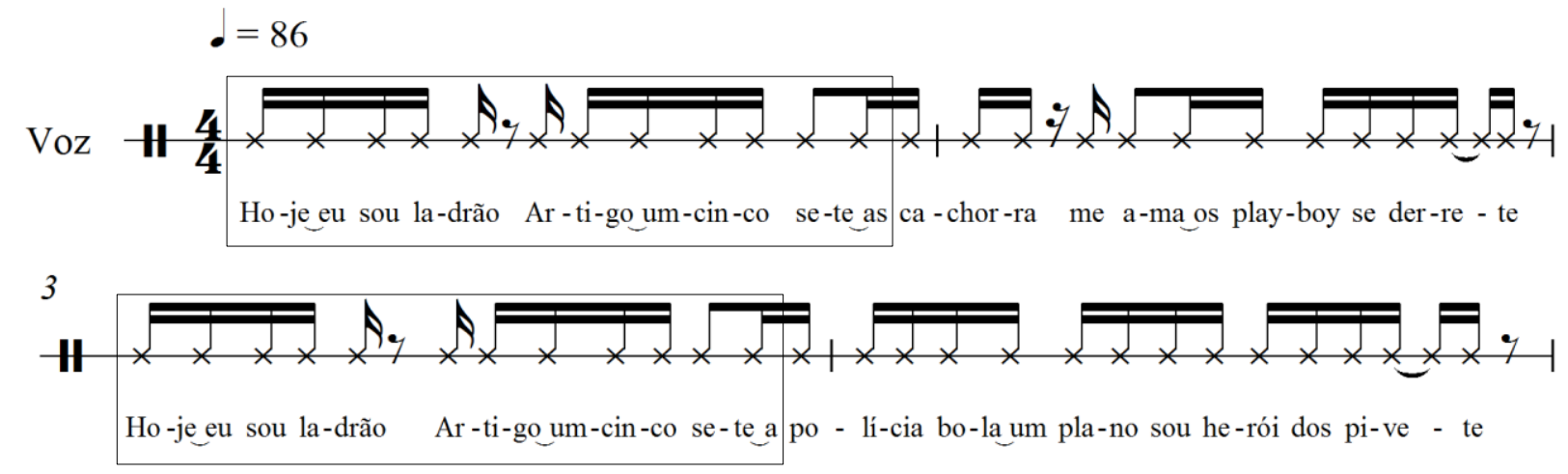

Figura 2.2-9: Еu sou 157 (Racionais MC’s) [Faixa 53]

O trecho transcrito acima é repetido sete vezes no decorrer de Eu sou $157^{66}$. Essa reiteração, por si só, já concede a ele o estatuto de refrão. Além disso, observamos que o fragmento é formado por duas frases muito semelhantes, tanto na forma musical adotada quanto no conteúdo da letra. O ritmo da primeira frase (compassos 1 e 2) é praticamente idêntico ao ritmo dos dois compassos seguintes e a ideia também permanece a mesma: cantar e decantar a figura do ladrão. Em ambas as frases, essa personagem é alvo de admiração e importância: as mulheres o amam, a elite o teme e respeita, a polícia o persegue e as crianças o veneram. Está materializada a figura do bandido. Aliás, é comum encontrarmos nas composições dos MC's esse tipo de temática na qual a exaltação de personagens ligadas ao crime torna-se uma maneira de fazer a população pobre obter certo nível de respeito. Nesse sentido, a periferia só é realmente atendida quando ameaça a tranquilidade das classes sociais mais abastadas. Enfim, percebemos no exemplo acima que a continuidade entre as figuras rítmicas adotadas e o conteúdo tratado colabora para expressar o estado conjuntivo entre o sujeito (ladrão) e seu objeto (admiração e respeito). Significa, para essa canção, um momento de pausa em relação às tensões tratadas nas outras partes da letra, quando são narrados eventos em que o personagem está sob a ameaça da polícia, por exemplo. Assim, no rap, a conjunção dificilmente é plena, tendo em vista a predominância do teor disjuntivo na maioria das obras. A alegria geralmente dura pouco.

Faz frio em São Paulo

Pra mim tá sempre bom

${ }^{66}$ In: Nada Como Um Dia Após O Outro Dia (Chora Agora) (2002) 
Eu tô na rua de bombeta e moletom

Dim dim dom

Rap é o som que emana do Opala marrom

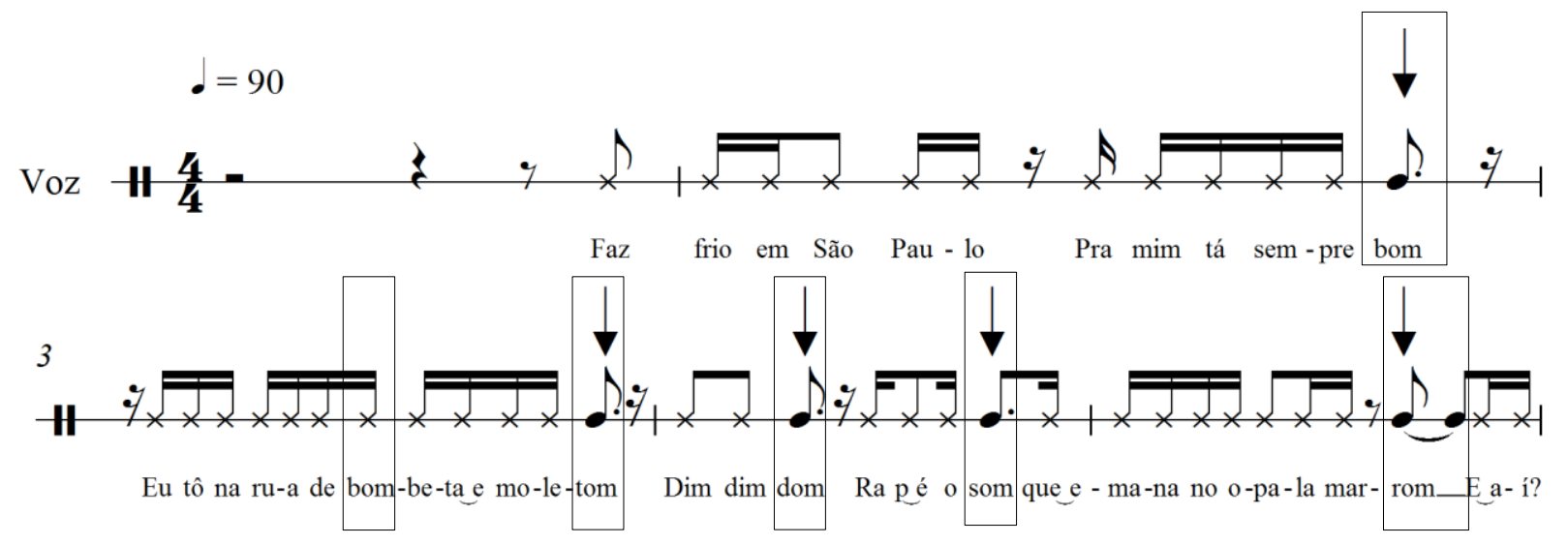

Figura 2.2-10: Capítulo 4, versículo 3 (Racionais MC's) [Faixa 54]

Sonoramente, observamos características de tematização na semelhança entre as figuras rítmicas que se repetem, no alongamento das durações que recaem sobre os acentos tônicos de certas palavras ("bom", "moletom", "dom”, "som" e "marrom") e nessas numerosas rimas terminadas em “om”. É relevante sublinhar que todas as sílabas destacadas com uma seta na partitura, além de alongadas com durações muito próximas (colcheia pontuada), também são emitidas com uma mesma altura. Isto é, ouvimos uma frequência definida quando o MC canta essas sílabas e possivelmente é o aumento da duração que nos permite essa escuta. Essa identidade sonora é indício da conjunção entre sujeito e objeto que também podemos verificar no conteúdo da letra, já que, apesar do frio, o personagem está cheio de contentamento. A disjunção, no entanto, está sempre ali, à espreita: a cidade é hostil do ponto de vista climático (tendo em vista a baixa temperatura) e social (na sequência, a letra retrata o risco do contato com as drogas no cotidiano da periferia).

Há exemplos muito interessantes que ilustram de que maneira elementos sonoros semelhantes aos observados acima trazem um mínimo de musicalização à figurativização reinante. No primeiro capítulo, analisamos canções nas quais havia a presença direta da fala, sem nenhum nível de musicalização. São, sobretudo, momentos em que o MC dialoga com outro rapper (que insere pequenos comentários falados interagindo com a letra entoada pelo cantor principal). Nesse segundo capítulo, nos interessa observar algumas canções nas quais essas falas ganham uma pequena 
estabilidade sonora que as tornam menos próximas da língua oral. Podemos examinar esse tipo de construção em dois trechos da canção $A$ vítima ${ }^{67}$ dos Racionais MC's.

Os cara me perguntando:

- E aí mano, cê tá legal?

Cheiro de éter no ar nunca é bom sinal

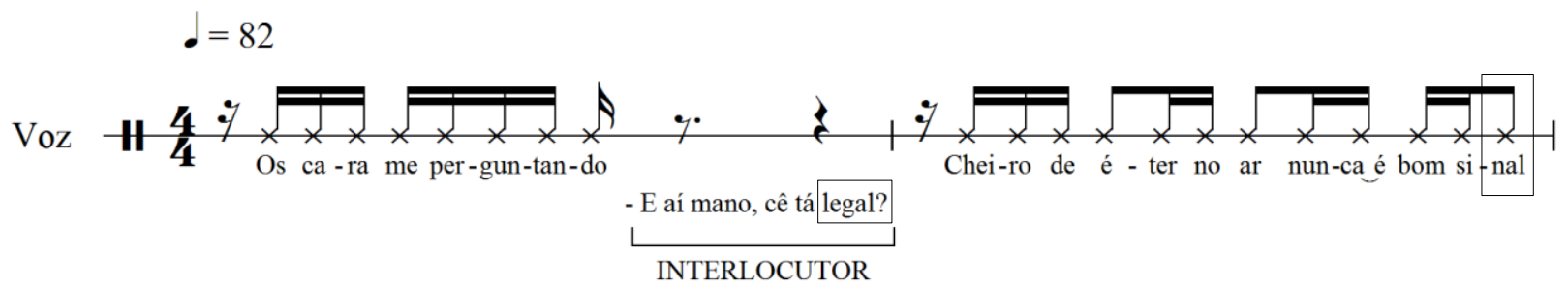

Figura 2.2-11: A vítima (Racionais MC's) [Faixa 55]

O porteiro tiozinho lembra meu pai

- Que andar? Qual andar que cê vai?

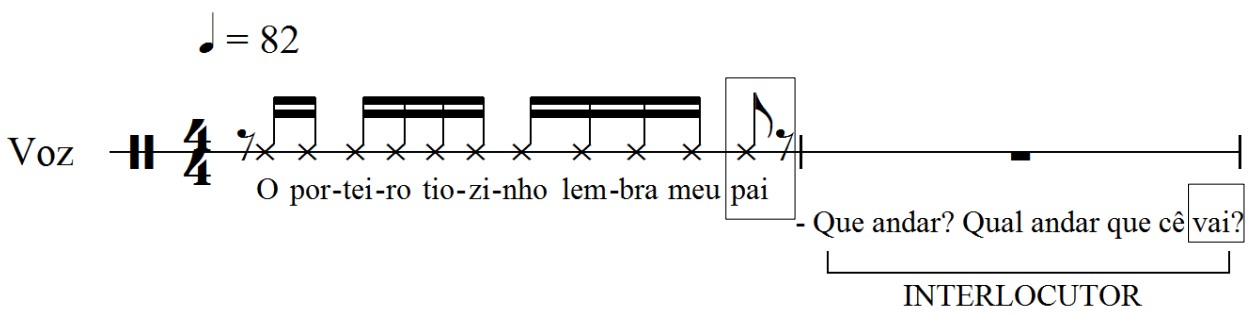

Figura 2.2-12: A vítima (Racionais MC's) [Faixa 56]

Nesses exemplos, notamos a voz de um interlocutor interagindo com o canto de Edy Rock. A vítima narra a história do acidente automobilístico ocorrido com o rapper em outubro de 1994, em São Paulo, que resultou na morte de uma pessoa. No decorrer da canção, enquanto o $\mathrm{MC}$ faz o relato do desastre e de suas consequências, alguns personagens da história ganham voz para que os momentos narrados se presentifiquem. Na figura 2.2-11, a letra refere-se ao momento exato do acidente, quando Edy Rock, ainda desorientado pelo ocorrido, recebe o socorro de seu amigo: "E aí mano, cê tá legal?”. Essa fala poderia se configurar como uma exclamação direta da língua oral que não possuísse qualquer estabilização musical. Contudo, o seu encaixe nas lacunas do canto do rapper (há um sentido musical na junção entre essas diferentes vozes) e a terminação da frase com a palavra "legal" rimando com o verso seguinte do MC

\footnotetext{
${ }^{67}$ In: Nada como um dia após o outro dia (2002)
} 
(“Cheiro de éter no ar nunca é bom sinal”) já representam certo nível de estabilidade musical que sutilmente minimiza a presença mais direta da língua oral. De maneira semelhante, na figura 2.2-12, a voz do porteiro que conversa com Edy Rock é totalmente instável ritmicamente, mas rima com a passagem anterior cantada pelo MC. A frase "Que andar? Qual andar que cê vai?" apresenta uma reformulação ou redundância muito característica da língua falada, mas a concordância sonora entre as palavras "vai" e "pai" já nos indica a existência de uma preocupação musical mínima. Enfim, ambos são exemplos de como podemos detectar aspectos musicais mesmo em trechos marcadamente figurativos, cujo trabalho sonoro pode parecer nulo para um ouvinte mais desatento. Isoladamente, essas frases são extremamente figurativas, mas tornam-se estáveis e perdem sua espontaneidade quando inseridas na canção. Por outro lado, nessa mesma obra, identificamos passagens em que a voz do interlocutor aparece totalmente estabilizada.

Meus parceiros me contaram

Cena após cena, passo a passo o que presenciaram:

- Mano foi um arregaço na marginal. Você capotou, teve até uma vítima fatal. Da zona sul e tal, sentido ao centro, uma da manhã...

Lembrei daquele momento

Vários opala

Mó carreata
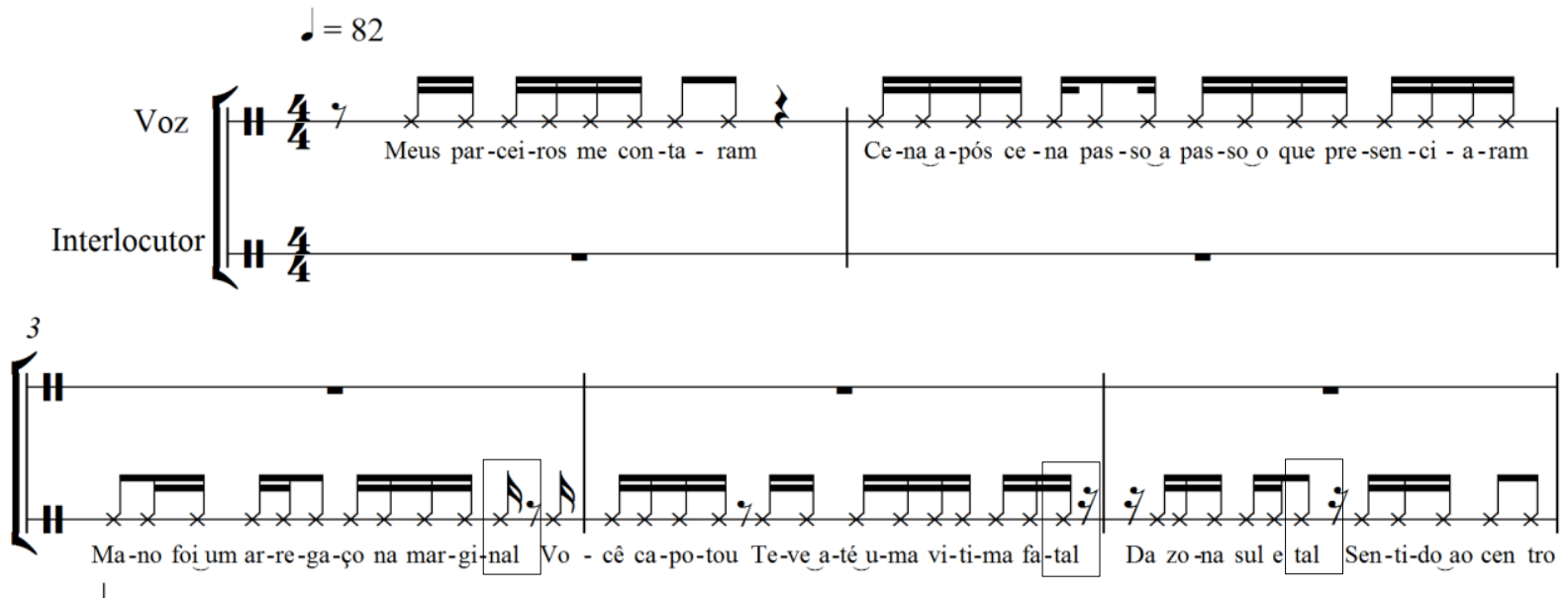

INTERLOCUTOR

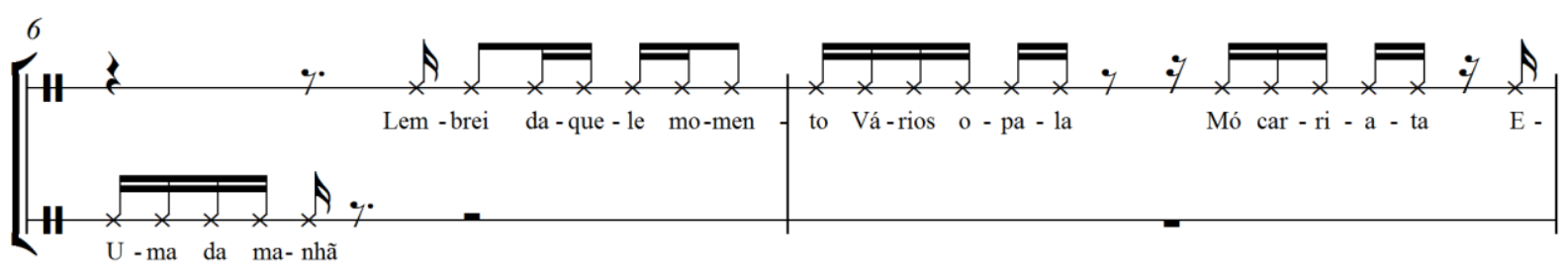

Figura 2.2-13: A vítima (Racionais MC's) [Faixa 57] 
Diferentemente das figuras anteriores, aqui a intervenção realizada sobre o canto do rapper apresenta uma configuração rítmica regular. Nesse fragmento, assim como na figura 2.2-11, o MC também dá espaço para que se presentifique uma conversa ocorrida no passado. Na passagem acima, a voz do amigo, cantada por Ice Blue, relata para Edy Rock (que na ocasião estava desacordado em consequência do acidente) como ocorreu o desastre. Como constatamos nos exemplos tratados no primeiro capítulo, essa interlocução de Ice Blue poderia muito bem possuir uma forma sonora absolutamente instável. No entanto, a sua musicalização é evidente, pois a letra é executada com divisão rítmica regular (é possível subdividi-la binariamente em semicolcheias), além da presença das rimas ("marginal", "fatal" e "tal").

Analisamos anteriormente a configuração rítmica mais usual da melodia do rap. Observamos a predominância da divisão do pulso em quatro partes iguais, mas também a presença de figuras pontuadas, com a alternância de sílabas breves e longas. Verificamos igualmente que esse tipo de regularidade rítmica, por ser muito utilizada pelo MC (além do fato de o canto se dar no registro de altura da fala) faz como que a figurativização prepondere: como grande parte das canções possui a mesma divisão rítmica, para o ouvinte, essa homogeneidade sonora praticamente anula o caráter musical do canto. Contudo, há canções em que são empregados desenhos rítmicos diferenciados que tornam as unidades entoativas realizadas pelo MC um pouco mais distantes da fala coloquial, ainda que plausíveis. São processos tematizantes que nos interessam nesse momento. Observamos um bom exemplo na melodia da canção Negro Drama $^{68}$.

Hei, senhor de engenho, eu sei quem você é

Sozinho cê num guenta, sozinho cê num entra a pé

Cê disse que era bom e a favela ouviu

Lá também tem uísque e Red Bull, tênis Nike e fuzil

Admito, seus carro é bonito, é, e eu não sei fazer

Internet, videocassete, os carro lôco

Atrasado eu tô um pôco, sim, tô, eu acho,

Só que tem que seu jogo é sujo e eu não me encaixo

${ }^{68}$ In: Nada como um dia após o outro dia (2002) 

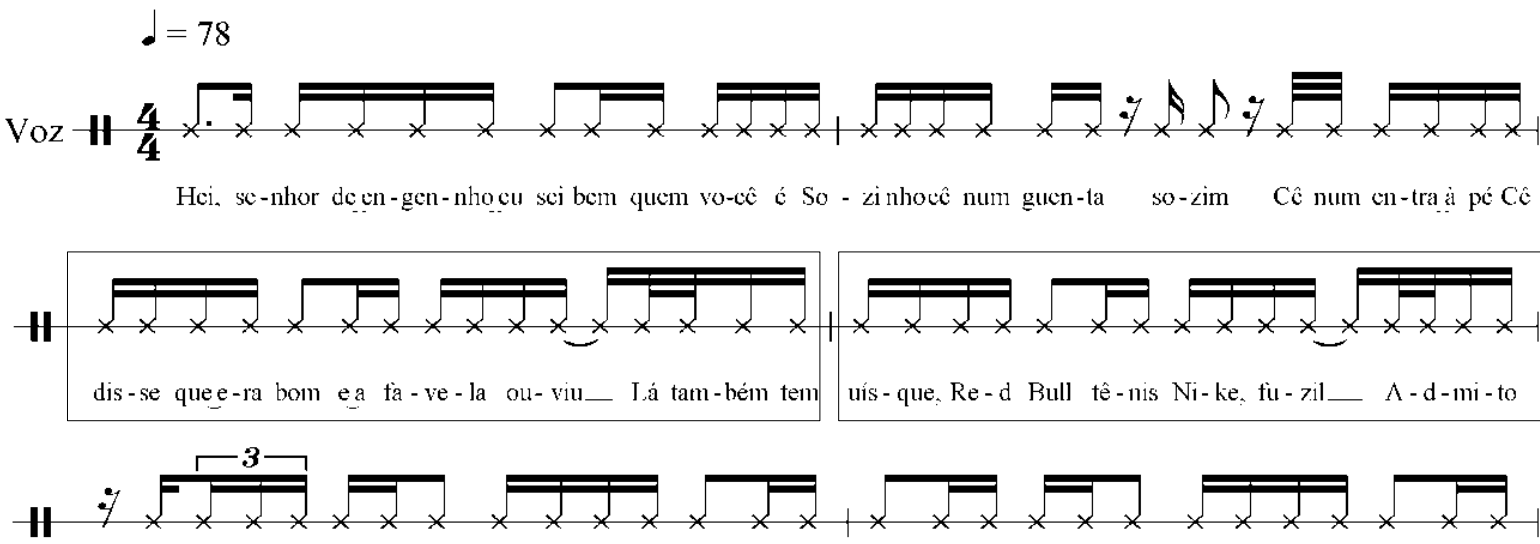

seus car-roé bo-ni-to é, Lieu não sei fa-zer in-ter - ne - $t$ vi-deo cas-se - te os car-ro lô-coa-tra-

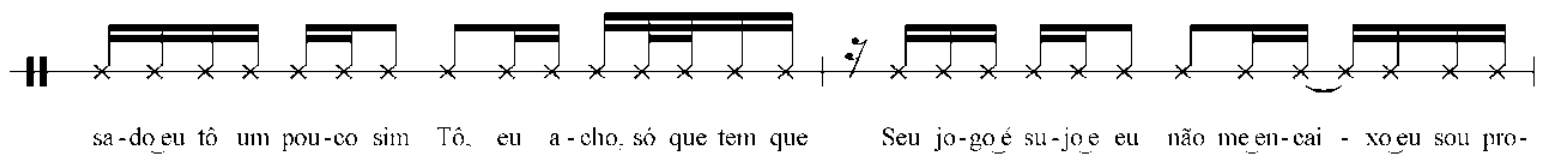

Figura 2.2-14: Ritmo da melodia de Negro Drama [Faixa 58]

Há, sem dúvida, a presença marcante da tematização melódica. Podemos observar a formação de padrões rítmicos na melodia do canto, construções que restabelecem a música diante da figurativização hegemônica. Por exemplo, na segunda linha da figura acima, o quarto compasso repete a mesma divisão rítmica do compasso anterior. As melodias que recobrem as duas linhas abaixo são idênticas sonoramente.

disse que era bom e a favela ouviu. Lá também tem uísque e Red Bull, tênis Nike e fuzil. Admito

Também notamos passagens nas quais o ritmo adotado pelo MC torna a melodia distante da entoação da fala. Por exemplo, as fusas do compasso 2 ("Cê num entra a pé”), do compasso 3 ("Lá também tem"), do compasso 4 (“Admito") e do compasso 7 ("Só que tem que") são motivos com apelo claramente musical. É importante, no entanto, examinar de que maneira essas passagens mais musicais atuam no interior das canções, observando a perda ou a permanência do gesto entoativo e a maneira como se equilibra a presentificação locutiva na relação do intérprete com o ouvinte ${ }^{69}$. Desse modo, é necessário verificarmos se há compatibilidade entre a letra e a melodia, mesmo quando essa correspondência não se dá por meio de uma construção figurativa,

${ }^{69}$ Como vimos no primeiro capítulo, o ouvinte tende a aceitar como verdade algo que é dito de forma verdadeira. Assim, segundo Luiz Tatit, esse processo de interação entre o cantor e o público estaria ligado a um forte sentido de "presentificação locutiva" capaz de assegurar a sua eficácia e o seu encanto: "O primeiro [cantor] tenta fazer com que o segundo [público] reconheça, na canção, uma situação de locução possível na vida cotidiana. Em outras palavras, a persuasão (...) se verifica através da impressão de que, não só a situação relatada é possível (parece "realidade"), como está sendo vivida no exato momento em que a canção se desenrola." (TATIT, 1986:9). 
fenômeno mais comum no rap. Devemos avaliar se esses gestos musicais atuam em favor dessa compatibilidade. No exemplo acima, notamos a agilidade de figuras rítmicas que colaboram para fortalecer a entoação agressiva do intérprete. Percebemos então que os elementos musicais fazem parte do projeto entoativo do cantor: a agressividade rítmica da melodia coincide com a agressividade da entoação da letra e do conteúdo dos versos. Assim, podemos constatar que a tensividade da letra comparece na melodia da canção. Pelo caminho da música, porém, e não da fala. Ainda que o rapper utilize elementos mais musicais do que entoativos (pensando na tematização sugerida pela repetição dos motivos rítmicos destacados acima), a relação entre a melodia e a letra sempre permanece plausível para o ouvinte. E se algumas vezes nem conseguimos compreender as palavras cantadas pelo MC, a sua dicção já satisfaz o público no sentido de lhe apresentar um modo de dizer:

\footnotetext{
Ao ouvinte importa bem mais o modo de dizer que o propriamente dito. Trata-se no limite, do mesmo efeito provocado pela canção em língua estrangeira: as modalidades da melodia (aquelas que definem o modo de relação do enunciador com o conteúdo do texto) já satisfazem o ouvinte com suas oscilações de intensidade. A qualidade do conteúdo, aquilo de que se trata, pode jamais chegar ao seu conhecimento (TATIT, 2002: 272).
}

Exemplos nos quais a divisão rítmica adotada pelo $\mathrm{MC}$ torna seu canto menos figurativo são comuns no rap. Observamos nesses casos uma estabilização musical mais pronunciada. Por um lado, as figuras podem apresentar durações muito breves, como no fragmento acima de Negro Drama (quando as frases são cantadas com maior velocidade), o que pode até mesmo dificultar a compreensão da letra por parte dos ouvintes. Por outro, as frases cantadas pelo rapper podem exibir um padrão rítmico incomum, diferente da utilização usual da subdivisão melódica em quatro ataques por pulsação. Aliás, a predominância do encaixe do texto verbal na base instrumental a partir desse padrão de subdivisão binária faz com que outras propostas rítmicas adotadas pelos MC's se tornem singulares para o ouvinte. Configuram-se como trechos melódicos especiais, ganhando alteridade em relação ao restante da composição. Assim, a organização sonora regular com a qual se canta a maioria dos versos se associa fortemente com a figurativização geral do canto e torna-se de certa maneira inaudível enquanto música, como se a priori não houvesse formalização musical no rap. Então, parece-nos que o público somente percebe mais fortemente a musicalização quando o 
MC adota um desenho rítmico diferente dessa subdivisão binária do pulso. Na figura abaixo, por exemplo, há momentos em que o canto abandona esse padrão rítmico. É quando observamos um caráter mais musical do que figurativo.

Viver a vida intensamente e sem dilemas

Os ricos são tão pobres que nem percebem a frieza

A triste pobreza em que usufruem suas malditas riquezas

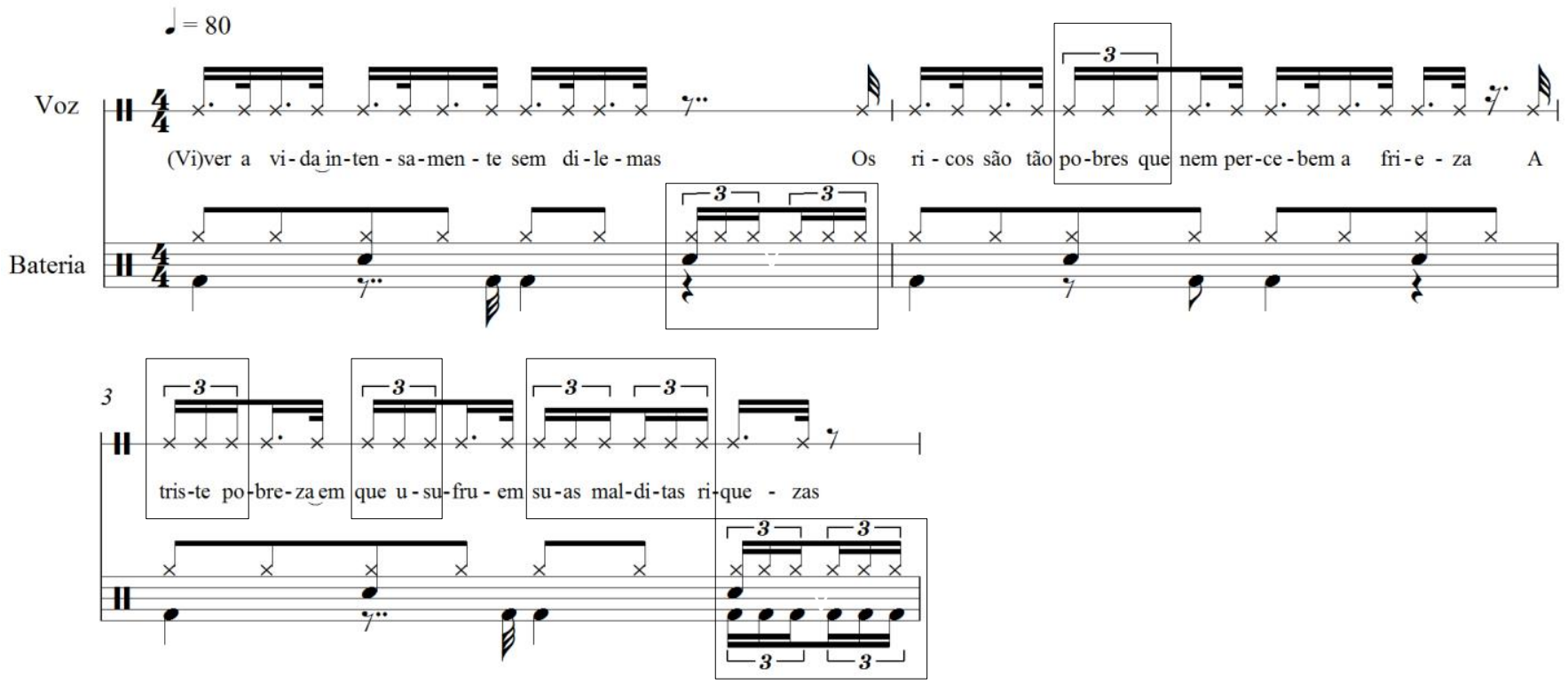

Figura 2.2-15: Talvez seja querer demais (GOG) In: Tarja preta, 2004 [Faixa 59]

A presença da subdivisão do pulso em quatro partes é predominante, dessa vez, com a alternância de figuras pontuadas e simples (longas e breves, respectivamente). No entanto, há momentos em que o MC entoa a letra com um ritmo diferente. Nos compassos dois e três, certos trechos das frases "Os ricos são tão pobres que nem percebem a frieza" e "A triste pobreza em que usufruem suas malditas riquezas" são cantados com divisão ternária do tempo, o que destoa fortemente da maneira mais usual e próxima à fala de se executar a letra (modo binário). Nessas passagens, é tão evidente o caráter mais musical do que figurativo que podemos até mesmo notar a influência direta de construções musicais presentes na base do DJ. Assim, no último tempo do primeiro compasso (linha do prato) e no último tempo do terceiro compasso (linhas do prato e do bumbo), há figuras idênticas às utilizadas no canto do rapper. Ou seja, as tercinas observadas no canto já estavam presentes na linha instrumental da bateria e possivelmente sugeriram ao MC essa divisão rítmica diferenciada. Ao trabalhar o 
encaixe da letra no acompanhamento instrumental, o cancionista certamente quis aproveitar elementos musicais já presentes no arranjo. Desse modo, construiu suas unidades entoativas que, embora inusitadas, são perfeitamente aceitas pelos ouvintes como maneiras de dizer possíveis. O próximo exemplo também ilustra um procedimento semelhante.

\section{Ouça-me}

Revolução de um bom ladrão

A voz de um gangster

Peço paz

Aos meus melhores irmãos que jaz

Os piores que permanecem brincando

Paz

Traz

Digitais
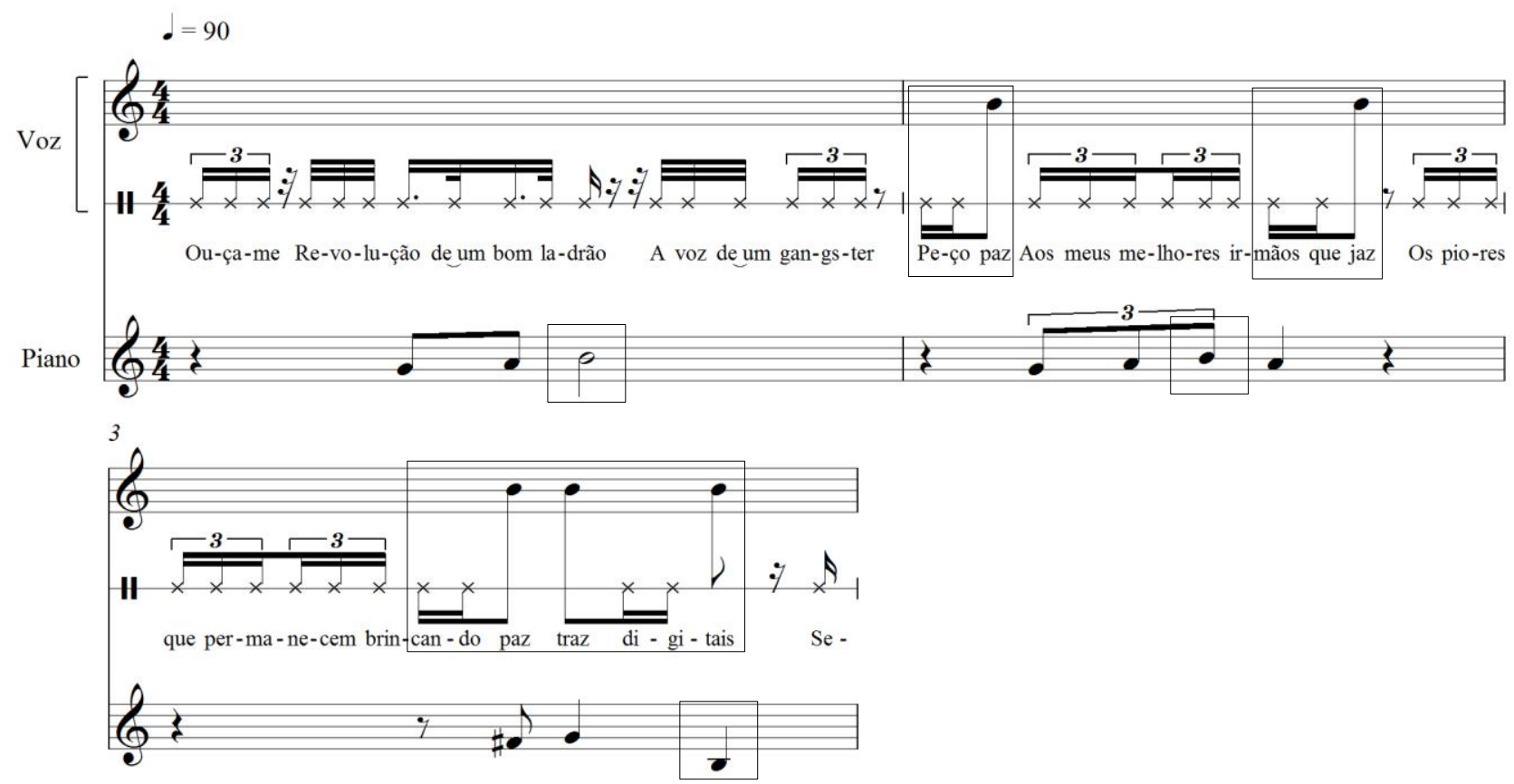

Figura 2.2-16: Voz do rapper Sabotage em Nem tudo está perdido (Posse Mente Zulu) [Faixa 60]

Tanto na canção Talvez seja querer demais quanto em Nem tudo está perdido notamos que o canto do MC aproveita aspectos musicais presentes no arranjo instrumental. Na figura 2.2-15, a influência é rítmica, pois o rapper canta com divisões ternárias sugeridas pela linha da bateria. Na figura acima, no entanto, a influência da base na emissão do cantor é notada em relação ao parâmetro altura. A voz de Sabotage, 
subitamente sai do registro de fala e passa a estabilizar em região mais aguda a nota $\mathrm{Si}$ natural, em diversas sílabas do texto verbal. Examinando a linha do piano notamos a presença marcante da nota $\mathrm{Si}$ (presente em todos os compassos transcritos acima). Assim, de forma semelhante ao que notamos na canção do grupo GOG, o rapper, ao compor sua letra, também aproveitou elementos sonoros da base do DJ. O resultado desse tipo de procedimento é muito interessante, pois essa reiteração sonora, por um lado, sugere a presença da tematização do canto (identidade de motivos) e, por outro, certo teor de passionalização ${ }^{70}$ : o salto intervalar, do registro de fala para a nota $\mathrm{Si}$ aguda, se liga perfeitamente ao conteúdo disjuntivo da letra (o sujeito pede paz diante de uma situação de sofrimento pela morte violenta de pessoas queridas).

Enfim, observamos que o trabalho artístico dos MC's certas vezes mobiliza aspectos mais musicais do que figurativos. Dessa maneira, não podemos ignorar a importância da música para esse gênero de canção. Ela está sempre ali, mesmo que tão concisa e reiterada, como assinalou Walter Garcia (2007: 198). Isto é, além dos valores entoativos sempre mais evidentes, há também fatores musicais importantes. As supressões na base instrumental que analisamos acima, os desenhos rítmicos diferenciados e as inúmeras possibilidades de variação na combinação entre a melodia do canto e o arranjo são exemplos disso. Constatamos, portanto, que o teor musical do rap está predominantemente ligado ao ritmo, com o DJ preparando as bases e o MC definindo a duração temporal dos vocábulos. Por isso o valor musical do rap é sempre questionado. Para grande parte dos ouvintes, cuja cultura musical sempre esteve ligada à canção tonal, com melodias perfeitamente estabilizadas e acompanhada por acordes, há certo estranhamento na fruição de um gênero cujo trabalho artístico não está centrado no parâmetro altura. Trata-se apenas de uma questão puramente cultural, já que há muitas tradições musicais em diferentes épocas e países que valorizam mais o aspecto rítmico do que a estabilização de notas musicais, como na música africana e oriental. Algo similar ocorre com a recepção da música erudita contemporânea europeia. Por exemplo, muitos compositores ocidentais do século XX se distanciaram do trabalho convencional com as escalas e harmonias do sistema tonal e passaram a trabalhar predominantemente com ritmos, texturas e timbres. Essa proposta estética, muito diferente da música tonal, naturalmente foi rejeitada pelos críticos e pelo público. Basta recordarmos a polêmica em torno da estreia de A sagração da primavera de Stravinsky,

\footnotetext{
${ }^{70}$ Estudaremos o processo da passionalização no capítulo seguinte.
} 
em 1913. Reação natural, já que os processos musicais atonais ainda não faziam parte do universo de escuta do ouvinte de música de concerto do início do século XX. Algo semelhante ocorre com o rap, cujo trabalho musical volta-se mais para o aspecto rítmico do que para a altura, abandonando a criação baseada em escalas e relações harmônicas. Dessa maneira, lembrando ainda que o rap é o gênero que mais evidencia o processo da figurativização na canção brasileira, podemos facilmente compreender o estranhamento causado nos ouvintes.

Como dissemos anteriormente, interessa-nos observar de que maneira a forma artística adotada pelos MC's se relaciona com a questão social sempre tão presente no hip hop. Portanto, desejamos encontrar na própria linguagem cancional, isto é, na relação entre a melodia e a letra (sem excluir aspectos musicais do arranjo que julgarmos relevantes), ligações com seu conteúdo de denúncia. Somente dessa maneira poderemos demonstrar o quanto essas obras são relevantes como reflexão sobre os assuntos políticos, pois se nos debruçarmos unicamente sobre o teor das letras, não estaremos valorizando os rappers enquanto cancionistas, mas apenas enquanto ativistas sociais. Valorizá-los exclusivamente por sua ideologia é perder de vista a força maior do que produzem. Os integrantes dos Racionais MC's são, de fato, pensadores perspicazes que possuem uma compreensão muito complexa da sociedade brasileira. No entanto, é apenas no momento em que essa visão crítica recebe uma forma artística determinada (letra e melodia sobre a base de um DJ) que sua mensagem ganha força na sociedade.

Estudamos no primeiro capítulo o quanto a figurativização é propícia para a veiculação de mensagens de conscientização social, pois a adoção do registro da fala aproxima os ouvintes da canção e do cancionista mobilizando-os de uma forma mais contundente. De maneira semelhante, os aspectos ligados à tematização estudados acima também podem se relacionar ao mesmo ímpeto de denúncia tão característico do hip hop. A sua força política também pode estar nas suas rimas e ritmos. Primeiramente, a estabilização musical, isto é, o delineamento das sonoridades das palavras e da base instrumental, torna o discurso mais perene e por isso mais forte, já que uma mensagem estabilizada se perpetua de maneira mais eficaz: a beleza da forma adotada atrai o ouvinte e o faz mais receptivo ao que é dito na canção. Por outro lado, o uso de samples retirados do repertório da black music (prática que é responsável por grande parte dos traços tematizantes que encontramos no rap) também representa uma importante atitude política, pois esses cantores norte-americanos das décadas de sessenta e setenta eram ícones de uma música de forte afirmação da cultura negra. As obras de James Brown e 
Jorge Ben, por exemplo, também cumpriam a função de valorização do negro num contexto de significativa segregação racial, tanto nos EUA quanto no Brasil. Mesmo que as canções não tratassem diretamente de problemas raciais, o valor agregado a elas e os eventos em que eram executadas carregavam forte teor político. Por isso, é interessantíssima no rap a coexistência entre a música dançante, geralmente conjuntiva, e a fala de protesto, suscitada por uma disjunção. Parece-nos que a presença de conteúdos conjuntivos, na black music e no hip hop, pode ter papel fundamental na autoafirmação e valorização do negro.

Além disso, construções tematizantes analisadas anteriormente como, por exemplo, certos motivos rítmicos encontrados na melodia de Negro Drama (figura 2.214), também podem conter um teor equivalente de protesto. São maneiras de entoar a letra que se distanciam da fala coloquial, mas que servem igualmente para veicular o mesmo conteúdo de denúncia observado nas partes mais figurativas dos raps. Assim como a dança que pode significar uma libertação do corpo, uma descarga de tensão acumulada ou uma simulação de ataque em relação a uma situação opressiva.

Enfim, observamos que tanto o lado figurativo quanto o lado tematizante do rap podem representar atitudes artísticas vinculadas a esse mesmo viés do protesto. Basta pensarmos na história do hip hop em São Paulo, já comentada anteriormente. Os pontos de encontro dos simpatizantes do movimento vão mudando geograficamente. No início, a Rua 24 de Maio configura-se como o espaço onde se reúnem Nelson Triunfo, o grupo Funk Cia e outros dançarinos e frequentadores dos bailes blacks. Em meados da década de 1980, o encontro desses jovens passa a acontecer na Estação São Bento do metrô. Posteriormente os praticantes de rap se deslocam para a Praça Roosevelt e os dançarinos de break (conhecidos como b-boys) permanecem na São Bento. Logo, constatamos que há no hip hop, de um lado, uma prática artística mais corporal, ligada à coreografia, e de outro, uma atividade mais intelectual, voltada para a canção popular. É significativo então que essa diferenciação espacial tenha ocorrido. Contudo, independentemente dessa separação, precisamos notar que ambas as linguagens cumprem a mesma função de denúncia. Obviamente, é mais explícita no rap e não no break a força do protesto, pois as letras fazem referências diretas às questões sociais ${ }^{71}$. Porém, a dança do hip hop também traz significativa carga política. Tanto que os encontros dos b-boys no centro da cidade eram manifestações que preocupavam fortemente as autoridades.

\footnotetext{
${ }^{71}$ Como vimos anteriormente, a questão social é tão presente no rap que os MC's criaram até mesmo diversas organizações de caráter político, as chamadas posses.
} 
A figura carismática de Nelson Triunfo e o talento dos dançarinos atraía o interesse dos passantes, que contribuíam dando algum dinheiro em um chapéu que passava ao final das apresentações. As rodas de break eram frequentemente desmanchadas pela polícia, mas os b-boys venciam pelo cansaço (TEPERMAN) ${ }^{72}$

Assim, a presença dos b-boys também representava uma atitude de confronto em relação ao Estado. O protesto estava nos passos da dança e na atitude de ocupar a rua. Da mesma forma, toda a cultura hip hop pode ser lida nessa mesma chave do enfrentamento $^{73}$. Um dos objetivos desse capítulo foi examinar de que maneira a linguagem da canção tematizante também contribui para essa postura combativa. Após analisarmos a presença da figurativização e da tematização no rap, nos resta agora estudar o último dos três processos composicionais estudados por Luiz Tatit, a passionalização.

\footnotetext{
72 TEPERMAN, Ricardo. Se liga no som - as transformações do rap no Brasil. São Paulo, ClaroEnigma, no prelo.

${ }^{73}$ Os artistas ligados ao grafite, por exemplo, são até hoje muito marginalizados.
} 


\title{
3 Passionalização
}

\subsection{A melodia passional}

O terceiro processo de compatibilização é aquele em que a melodia apresenta uma desaceleração pelo uso de figuras de maior duração e adoção de andamento geralmente mais lento (em oposição à aceleração do processo tematizante, necessária por seu apelo corporal nos gêneros de dança). Há uma ampliação significativa da tessitura do registro vocal e maior presença dos saltos intervalares. As tensões musicais advindas desse tipo de procedimento (por exemplo, com notas prolongadas em região aguda) têm, segundo Luiz Tatit, correspondência direta com as tensões presentes no conteúdo da letra que geralmente traz o sofrimento de um sujeito em disjunção com seu objeto.

\begin{abstract}
A dominância da passionalização desvia a tensão para o nível psíquico. A ampliação da frequência e da duração valoriza a sonoridade das vogais, tornando a melodia mais lenta e contínua. A tensão de emissão mais aguda e prolongada das notas convida o ouvinte para uma inação. Sugere, antes, uma vivência introspectiva de seu estado. Daqui nasce a paixão que, em geral, já vem relatada na narrativa do texto. Por isso, a passionalização melódica é um campo sonoro propício às tensões ocasionadas pela desunião amorosa ou pelo sentimento de falta de um objeto de desejo (TATIT 2002:23)
\end{abstract}

Vejamos então alguns exemplos de canções cuja relação entre melodia e letra contém marcas de passionalização. Na figura seguinte, observamos a transcrição de um trecho de Cantiga de Dorival Caymmi. Essa obra apresenta uma desaceleração da linha melódica e uma ampliação da tessitura. Na letra, o sentimento de falta por parte do sujeito.

Toda gente no mundo

Tem amor tem seu bem

Pra este canto do mundo

Só o meu que não vem

Cada trova que eu canto

Lembra uma mulher

Mas que serve esse pranto

Se meu bem não me quer, ai... 
Cada trova que eu faço

É uma recordação

Cada verso um pedaço

Deste meu coração, ai...

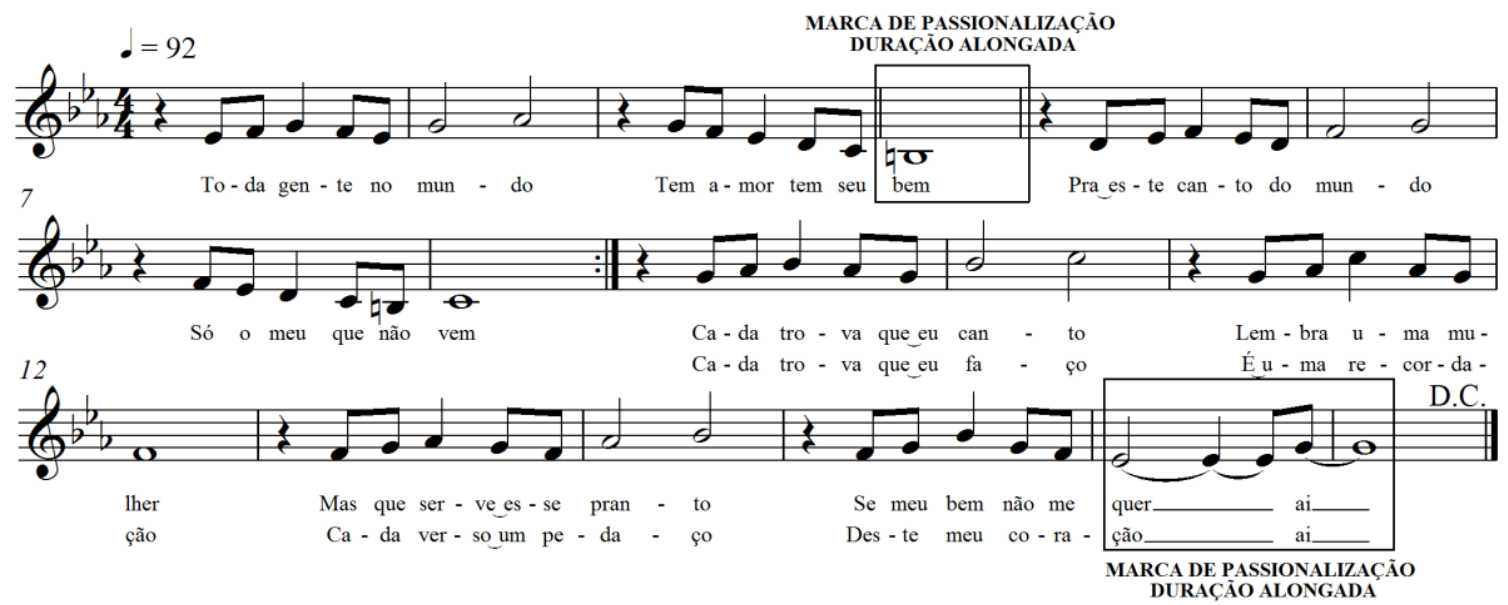

Figura 3.1-1: Cantiga (Dorival Caymmi) [Faixa 61]

Mesmo com a presença de certa regularidade rítmica sugerindo aspectos de tematização, predomina nessa canção a passionalização. É certo que a amplitude da tessitura de cada verso não chega a alcançar intervalos maiores do que uma $6 \mathrm{~m}$ (as notas Sol e Si que iniciam e finalizam o segundo verso "Tem amor tem seu bem"). Em verdade, na maioria das frases, a distância entre a nota mais grave e a mais aguda é de uma 4J: Mib e Láb em "Toda gente no mundo"; Ré e Sol em "Pra este canto do Mundo"; Sol e Dó em "Cada trova que eu canto"; Fá e Sib em "Mas que serve esse pranto". Mas ainda que a tessitura não seja muito extensa, as distâncias intervalares são valorizadas devido à desaceleração da melodia. $\mathrm{O}$ andamento colabora então para enfatizar tais intervalos. Esses, aliados ao prolongamento das notas nos finais de cada verso, sobretudo as notas agudas das frases ascendentes, geram uma tensão sonora que é compatível com o conteúdo da letra. No final da canção, nos dois últimos compassos do exemplo acima, o caráter de lamento é ainda mais evidente quando as notas Mi e Sol são alongadas sobre palavras cruciais para o sentido de sua letra. A nota Mi incide sobre a palavra "quer" na primeira versão do texto cujo verso "Se meu bem não me quer" nos traz o momento doloroso em que o sujeito assume a rejeição por parte de sua bemamada. Na segunda versão a nota recai sobre a última sílaba de "coração", na sugestão de um coração dilacerado. É nesse momento decisivo, para as duas versões da letra, que 
o vocábulo "ai", como um gemido de dor, prolonga-se na nota Sol da melodia. Em

Duas horas da manhã de Nelson Cavaquinho e Ary Monteiro notamos algo semelhante:

Duas horas da manhã

Contrariado espero pelo meu amor

Vou subindo o morro sem alegria

Esperando que amanheça o dia

Qual será o paradeiro

daquela que até agora não voltou?

Eu não sei se voltará

ou se ela me abandonou
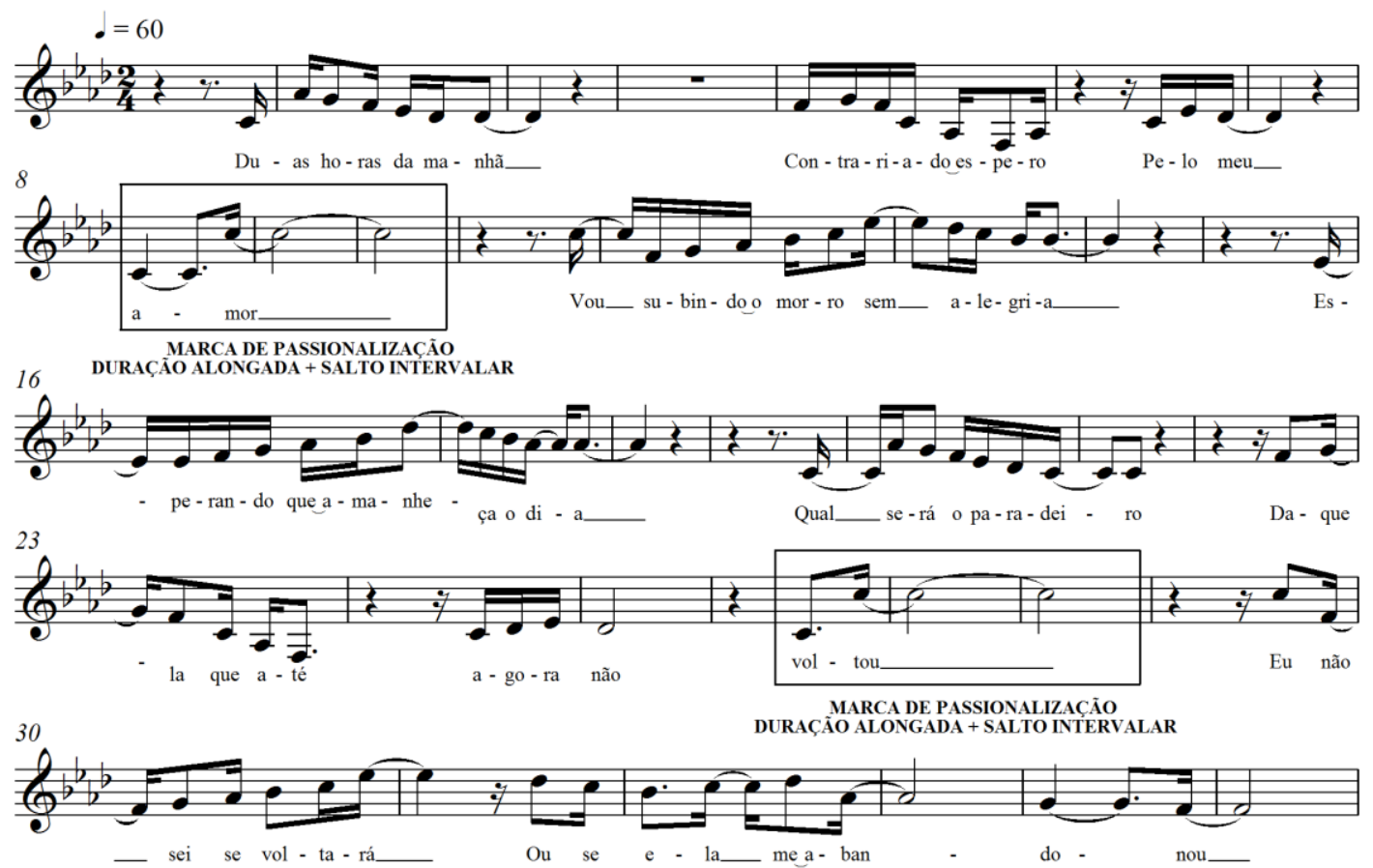

Figura 3.1-2: Duas Horas da Manhã (Nelson Cavaquinho/Ary Monteiro) [Faixa 62]

Se em Cantiga a tensão passional está mais concentrada no prolongamento das durações do que propriamente na questão da tessitura, nessa canção, além da presença da desaceleração, são os amplos saltos intervalares que mais chamam a atenção do ouvinte. A melodia, com quase duas oitavas de extensão (situada entre a nota Fá da terceira linha suplementar inferior e a nota Mib do quarto espaço), explora ascendências e descendências acentuadas, por meio de saltos, graus conjuntos ou arpejos. A tensão musical resultante dessa movimentação corresponde à tensão do conteúdo do texto 
linguístico no qual o sujeito aguarda a volta de sua amada, ao mesmo tempo em que lamenta sua ausência. Interessante notar que os saltos mais amplos, com intervalos de 8J, recobrem palavras essenciais para o teor de disjunção ligado à experiência amorosa mal sucedida: “(meu) amor” no compasso 8 e "(não) voltou” no compasso 26. Nesses dois trechos temos a impressão de uma passagem mais dolorosa, carregada do sentimento de falta referido acima por Tatit.

É importante destacar que a divisão estrita entre os três processos de combinação entre melodia e letra (figurativização, tematização e passionalização) é utilizada somente como procedimento analítico. ${ }^{74} \mathrm{Na}$ prática, no interior de uma mesma canção, há geralmente a integração entre os três recursos composicionais, mesmo que um deles seja proeminente.

Quem compõe canções concebe melodias por intermédio de leis musicais e leis linguísticas (...). Valendo-se de leis musicais o compositor detona os processos de tematização e passionalização. Com o que chamo de leis linguísticas, a figurativização. Partindo de um lado ou de outro, o cancionista só termina seu trabalho quando opera a integração entre leis musicais e leis linguísticas. (TATIT, 2002:73)

As duas composições brevemente observadas acima são exemplos claros de que as canções podem operar com mais de um processo simultaneamente. Em Cantiga, embora predomine a passionalização, temos a presença da tematização na regularidade e na repetição dos motivos e das partes e a sutil presença da atitude figurativa: nos dois primeiros versos, assim como no terceiro e no quarto, notamos uma elevação que mantém acesa a atenção do ouvinte e uma posterior descendência conclusiva (fases entoativas que, como vimos no primeiro capítulo, são características da língua oral). Já em Duas horas da manhã, ainda que marcadamente passional, encontramos uma força figurativa significativa, sobretudo por certa irregularidade dos padrões rítmicos da melodia, o que a torna próxima da entoação da fala. Enfim, não sendo nosso objetivo aprofundarmos a análise dessas duas canções, desejamos apenas destacar a natural convivência entre os diferentes processos cancionais. A consciência dessa simultaneidade é muito importante quando analisamos a presença da passionalização em canções do gênero rap, já que esse modo de compatibilização dificilmente estará à frente dos outros dois procedimentos.

\footnotetext{
${ }^{74}$ TATIT, 2002:24
} 
Assim, observamos na construção da melodia-letra do rap modulações tensivas entre os elementos entoativos e os elementos musicais tematizantes e passionalizantes. O objetivo desse capítulo é verificar de que maneira estão presentes, além do procedimento figurativo predominante e dos componentes musicais da tematização, os aspectos ligados à passionalização. Mais do que isso, acreditamos que o rap necessita de parâmetros diferenciados de avaliação em relação aos três princípios de compatibilização entre melodia e letra, pois pequenos gestos musicais em meio a um predomínio entoativo podem representar significativas inflexões passionais ou construções tematizantes fortemente musicais. Assim, essas questões podem se tornar mais significativas do que a própria figurativização, como se essa fosse neutralizada tendo em vista todas as obras desse estilo de canção se apoiarem predominantemente nesse recurso.

Nesse sentido, na tentativa de explicitar as nuances entre a fala e a música nesse tipo de canção, acreditamos que a semiótica tensiva pode contribuir significativamente para a análise, especialmente com a sua sintaxe dos aumentos e das diminuições, aquela que se debruça sobre as quantificações subjetivas. Lembramos, a propósito, que os mecanismos de oscilação de quantificação fazem parte dos processos mentais dos seres humanos e estão igualmente presentes na experiência de escuta das canções do gênero rap quando nos questionamos sobre a influência da fala e da música em sua construção. Vejamos na figura abaixo, como podemos representar essas modulações tensivas. Adotamos aqui o ponto de vista musical como base para quantificar as oscilações tensivas entre a música e a fala.

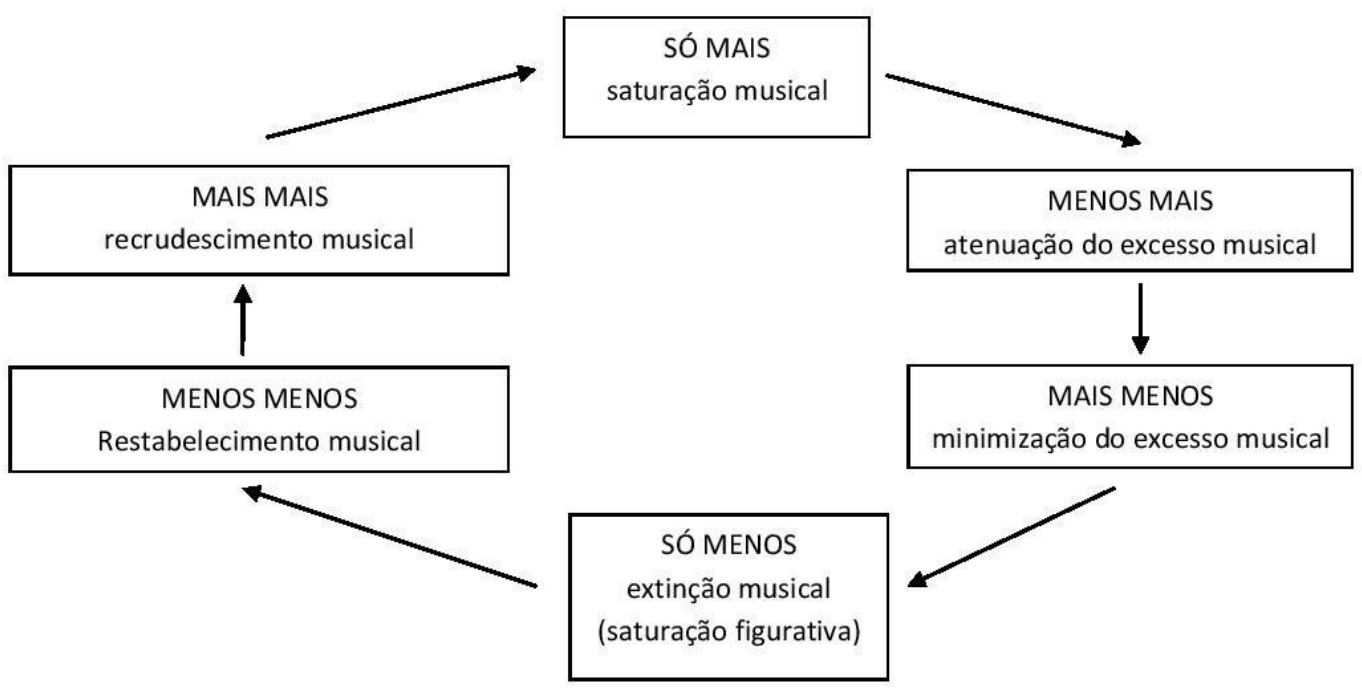

Figura 3.1-3: Modulações tensivas sob o ponto de vista musical 
As oscilações apresentadas na figura acima são significativas para o universo do rap, pois esse é o gênero de canção popular que mais se aproxima da extinção musical. Desse modo, as obras ligadas a esse universo em geral acabam se situando no nível da minimização musical (mais menos). Nesse momento, no entanto, nos interessa observar como certas canções, ao contrário, apresentam elementos que indicam um restabelecimento musical (menos menos). O objetivo do item seguinte é observar aspectos musicais ligados à passionalização presentes na entoação do cantor, em trechos instrumentais ou vocais e em samples utilizados pelos DJ's (por exemplo, inserções de músicas passionais de autores que fazem parte da história da black music das décadas de sessenta e setenta). 


\subsection{A passionalização no rap}

A princípio, pode parecer difícil a tarefa de encontrar elementos de passionalização nesse gênero de canção. O senso comum e o significado mais difundido do termo rap, como sigla para rhythm and poetry, já nos indica uma ênfase na figurativização (pela entoação de versos) e no recurso musical da tematização (pela presença marcante do ritmo com a estabilização de motivos realizada pelos MC's). Contudo, ao examinarmos mesmo que superficialmente obras dos principais rappers brasileiros, notamos a presença constante de elementos passionalizantes variados que diminuem essa remissão à fala. Para demonstrar o quanto essa característica é significativa para o rap destaquei uma canção de cada um dos grupos nacionais mais importantes. Assim, por exemplo, observamos a presença de refrãos passionais em raps de diversos autores:

Quem costuma vir de onde eu sou

Às vezes não tem motivos pra seguir

Mas eu sei que vai

Que o sonho te traz

Coisas que te faz prosseguir

Somos maior

Nos basta só sonhar, seguir
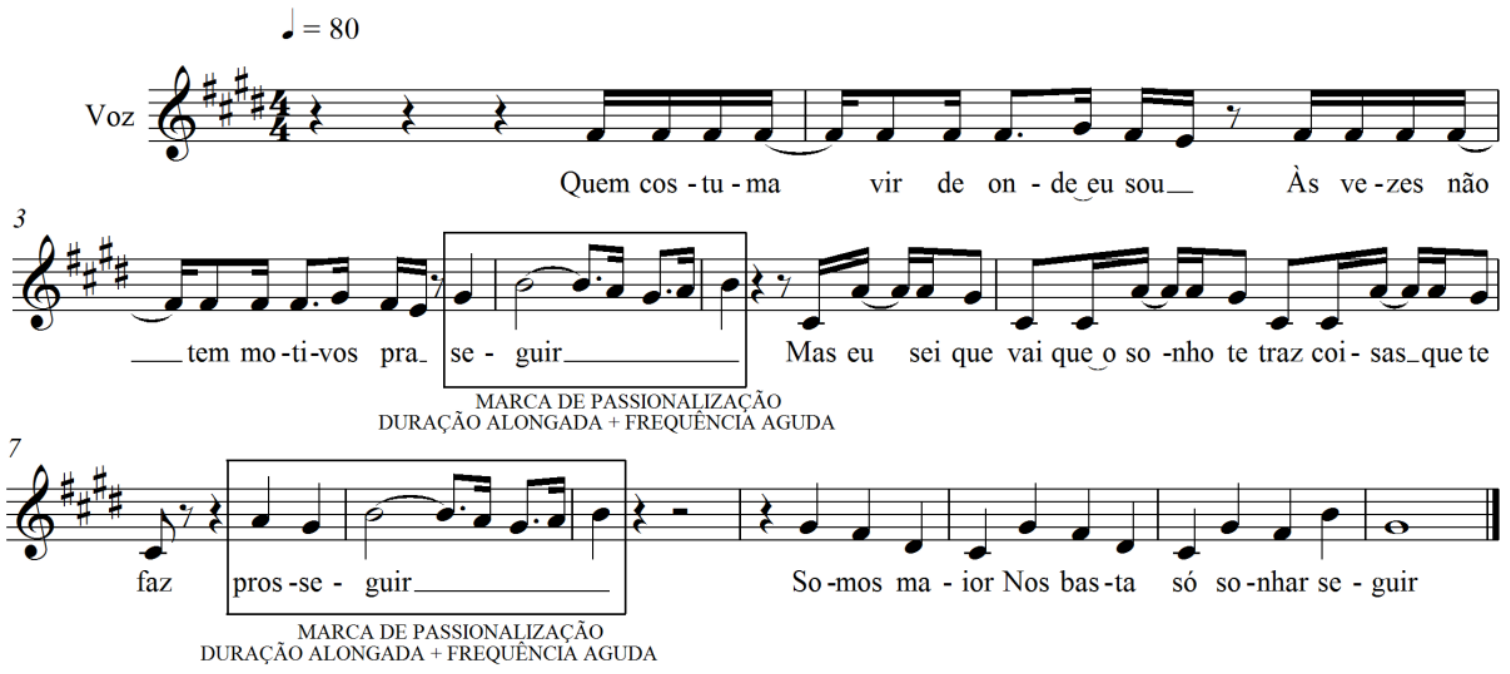

Figura 3.2-1: Levanta e anda (Emicida) In: O Glorioso Retorno de Quem Nunca Esteve Aqui, 2013 [Faixa 63] 
Zona sul

No Brooklin aprendi viver

E o respeito de um por um

Faz a paz prevalecer

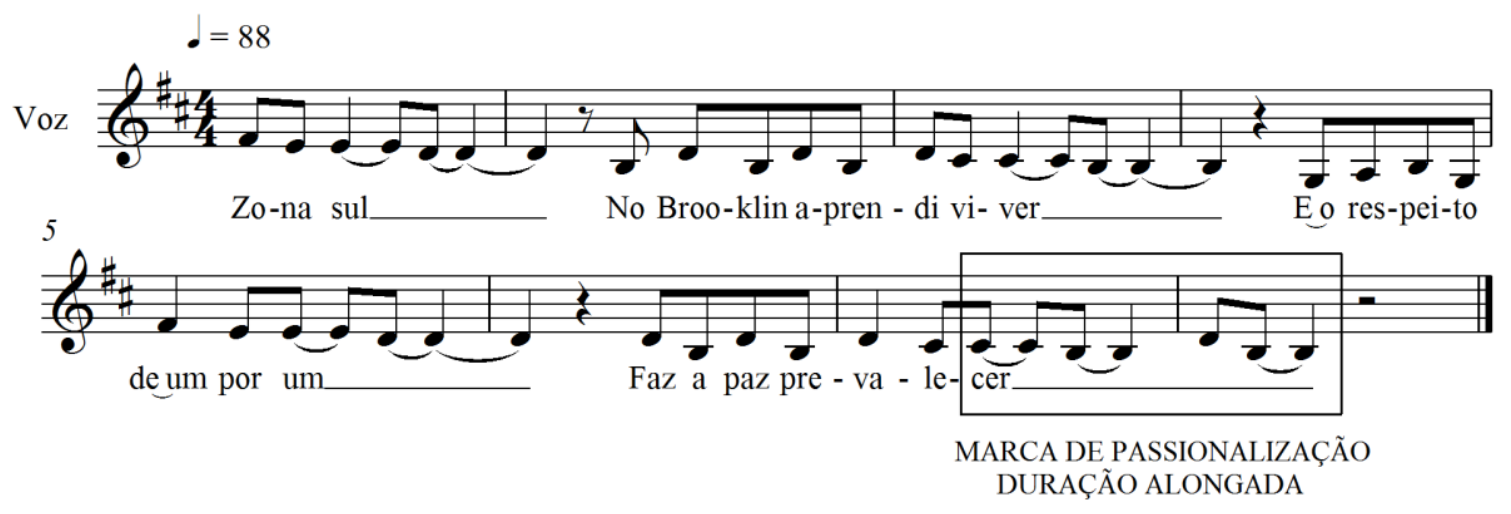

Figura 3.2-2: No Brooklin (Sabotage) In: Rap é Compromisso, 2000 [Faixa 64]

Ninguém sabe

Ninguém viu

Aquele mano chegou atirando

Pá e pum, caiu!

Antes ele do que eu

Não há mais o que fazer

Deixo nas mãos de deus

Foi assim que aquele mano se perdeu

O mano estava sozinho

Foi assim que aquele irmão morreu

E você está no caminho 


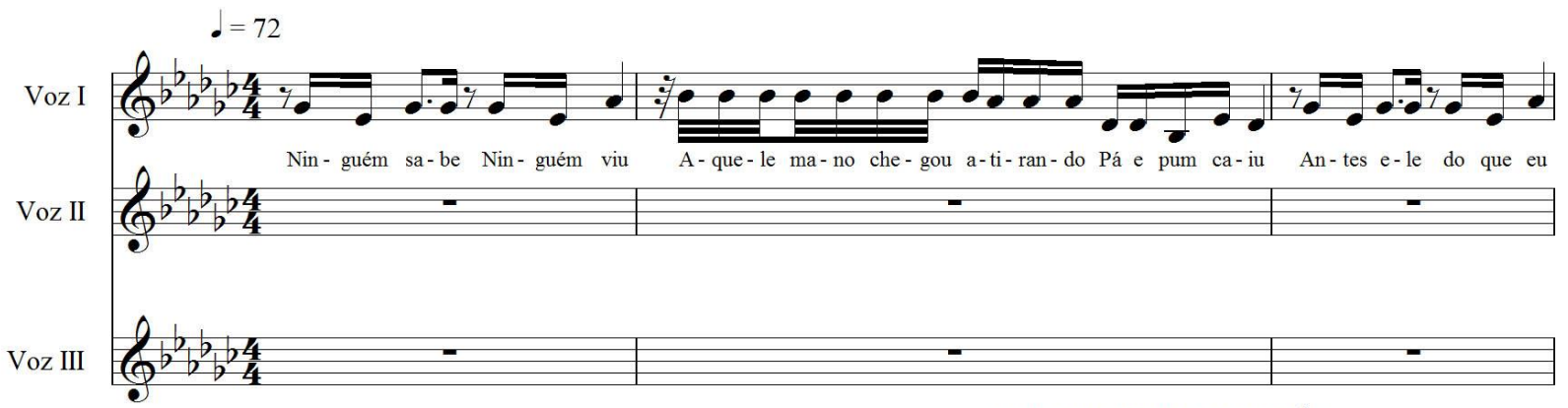

MARCA DE PASSIONALIZAÇÃO

DURAÇÃO ALONGADA + FREQUÊNCIA AGUDA
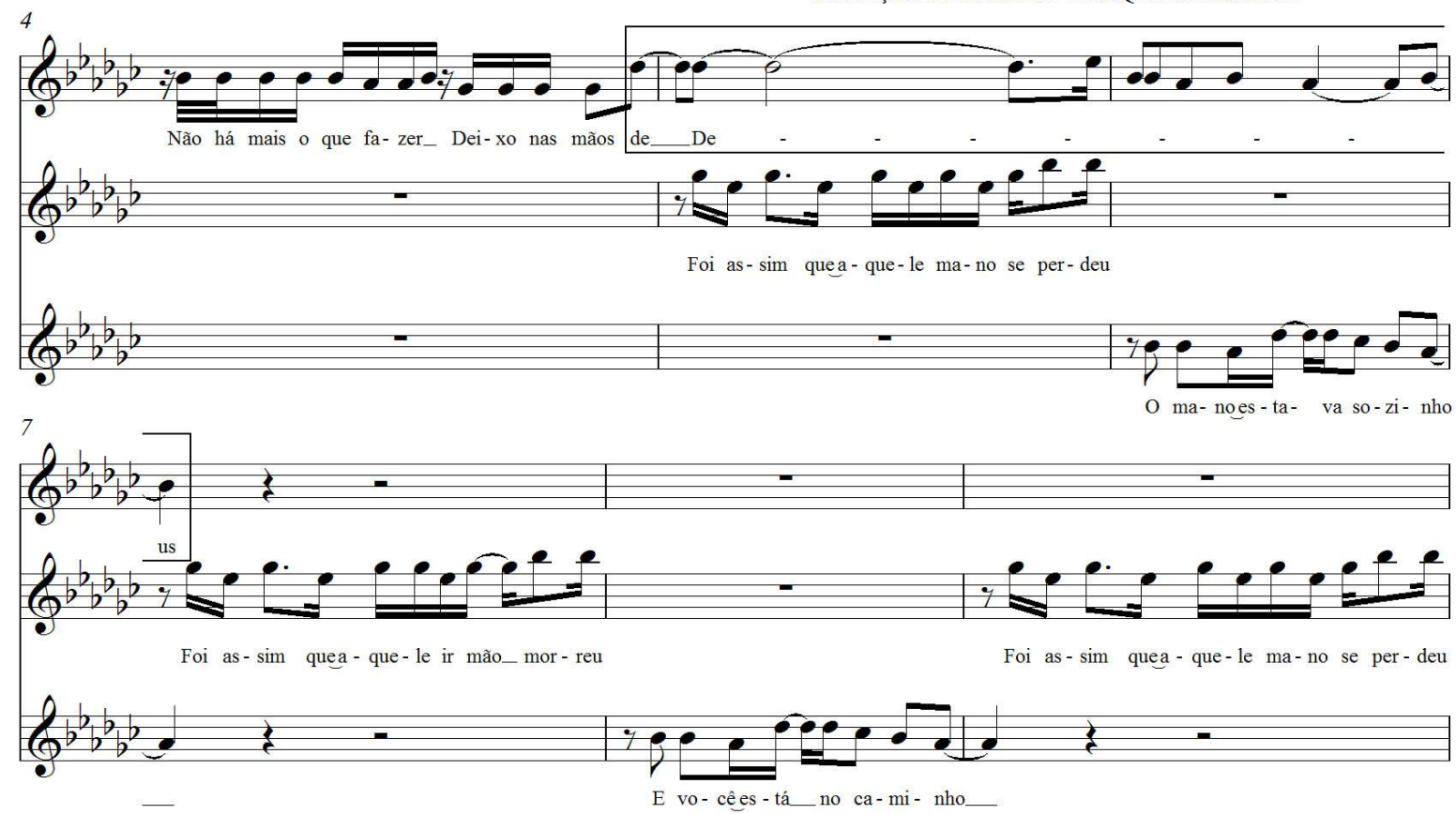

Figura 3.2-3: Ninguém sabe (Thaíde e DJ Hum) In: Assim Caminha a Humanidade, 2000 [Faixa 65]

Joga a última flor

Não chora quando o caixão partir

É a ponte elevadiça do castelo triste

Se abaixando pra eu fugir

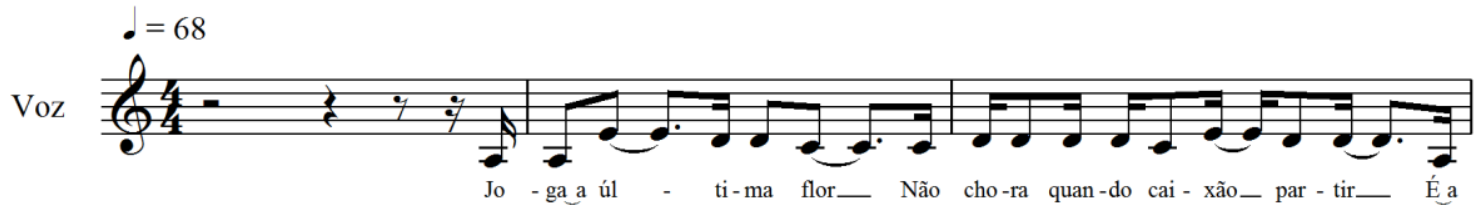

4

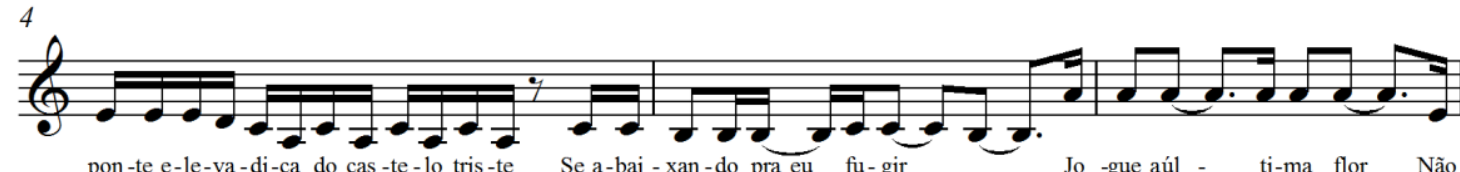

pon-te e-le-va-di-ça do cas -te-lo tris-te Se a-bai - xan-do pra eu fu-gir__ Jo -gue aúl - ti-ma flor_ Não

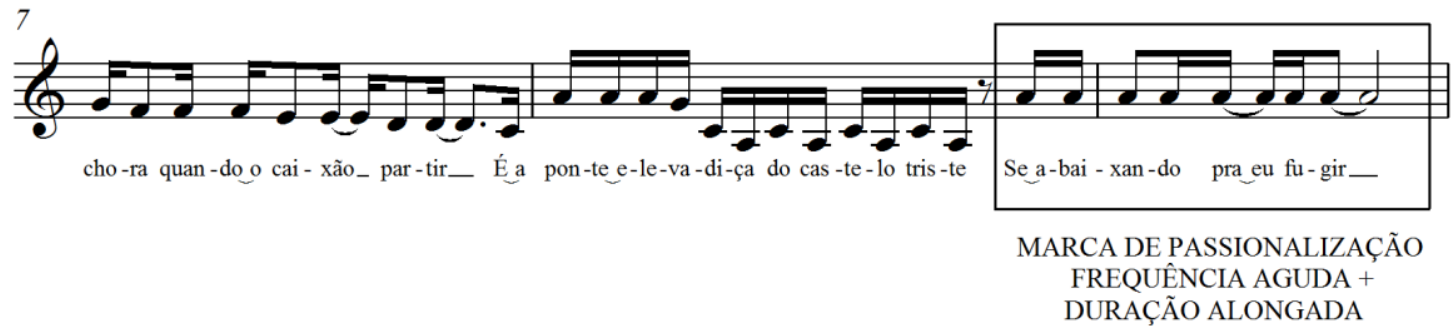

Figura 3.2-4: Castelo Triste (Facção Central) In: O Espetáculo do Circo dos Horrores, 2006 [Faixa 66] 
Eu vou procurar

Eu sei que vou encontrar

$\mathrm{Eu}$ vou procurar

Eu vou procurar

Você não bota uma fé

Mas eu vou atrás
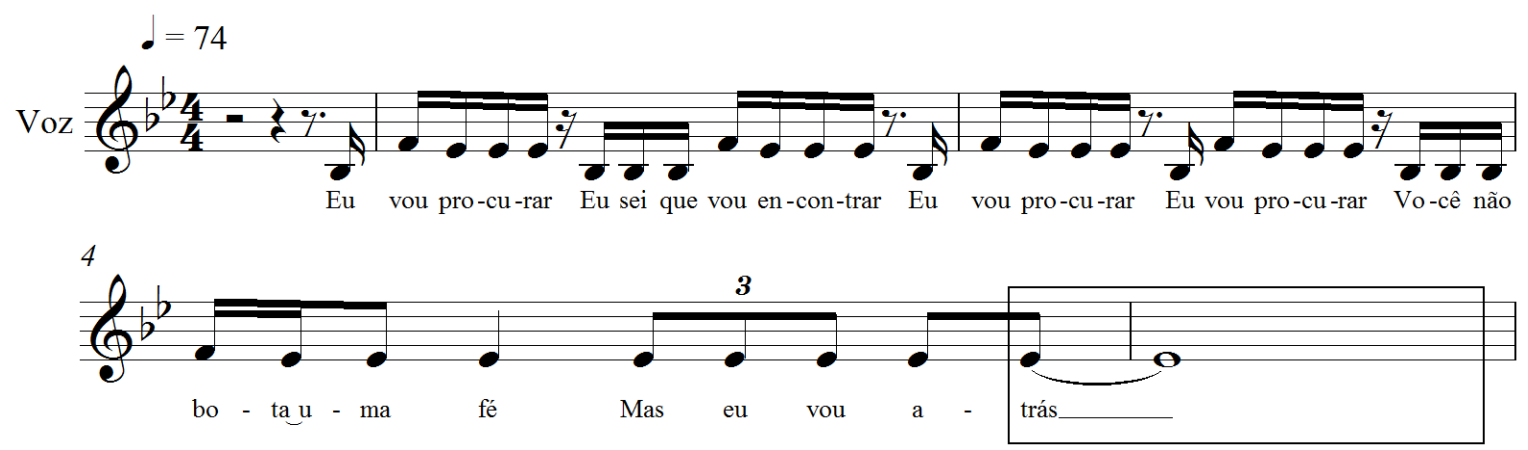

MARCA DE PASSIONALIZAÇÃO DURAÇÃO ALONGADA

Figura 3.2-5: Fórmula Mágica da paz (Racionais MC’s) In: Sobrevivendo no Inferno, 1998 [Faixa 67]

Então seja como Deus quiser

Então que seja

Seja como Deus quiser
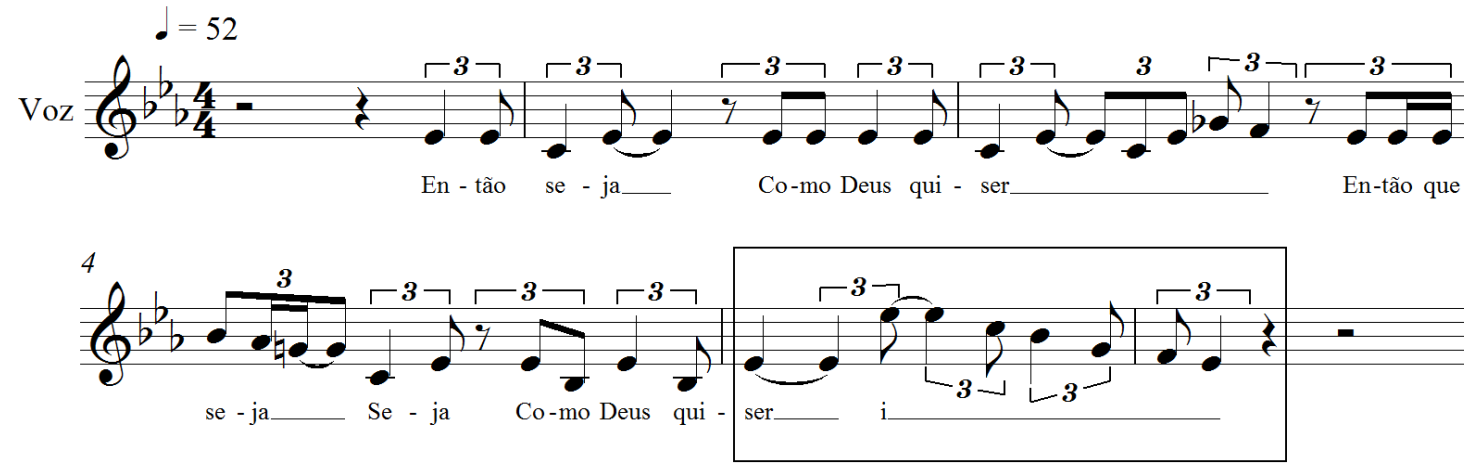

MARCA DE PASSIONALIZAÇÃO

DURAÇÃO ALONGADA + FREQUÊNCIA AGUDA

Figura 3.2-6: Estágio final (RZO) In: Todos são manos, 1999 [Faixa 68]

A saudade me faz chorar

Ah, se eu pudesse o tempo voltar

Seria um cara melhor sem desilusão

Sem desilusão 


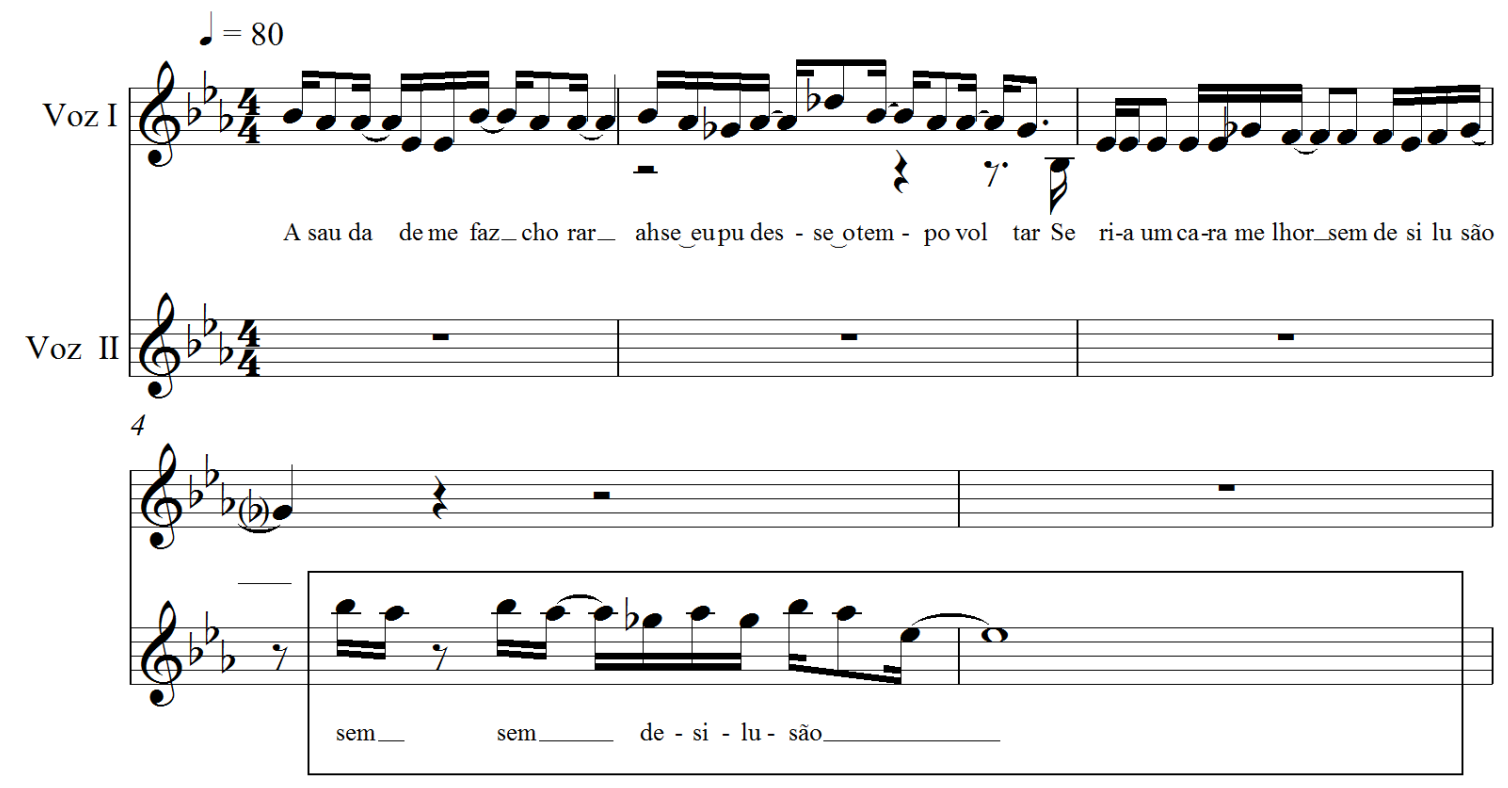

MARCA DE PASSIONALIZAÇÃO

DURAÇÃO ALONGADA + FREQUÊNCIA AGUDA

Figura 3.2-7: Passaporte pro inferno (Sistema Negro) In: Renascendo das cinzas, 2005 [Faixa 69]

Reggae music

Veio representar

Reggae music

Veio representar

Afrodescendente procurando um lugar

Luta pra vencer

Luta pra comer

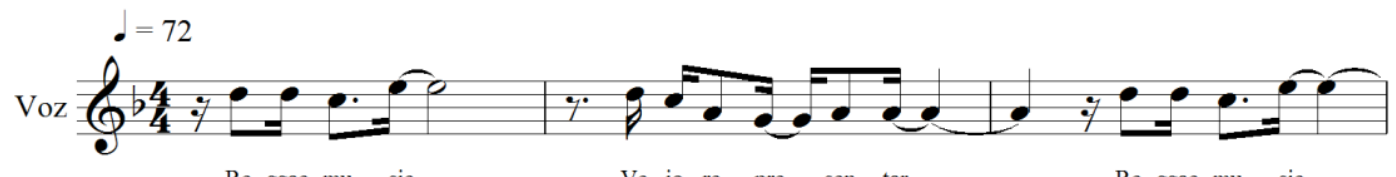

Re -ggae mu - sic

Ve - io re - pre - sen - tar

Re -ggae mu - sic

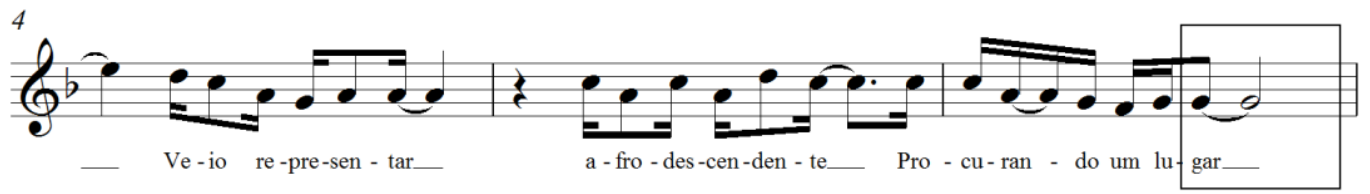

MARCA DE PASSIONALIZAÇÃO DURAÇÃO ALONGADA

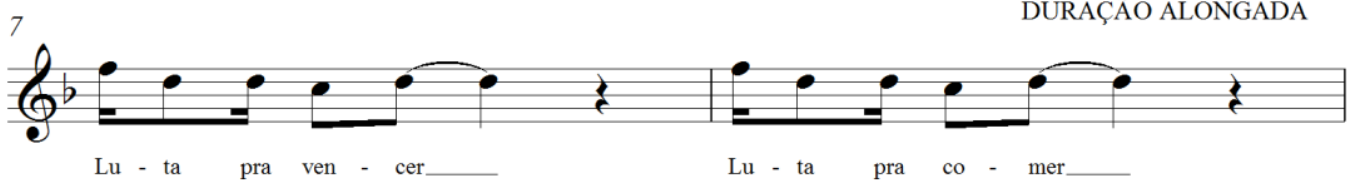

Figura 3.2-8: Passageiro da Agonia (De menos crime) In: O Revertério, 2005 [Faixa 70] 
O desconforto anda solto no mundo

O desconforto anda solto no mundo

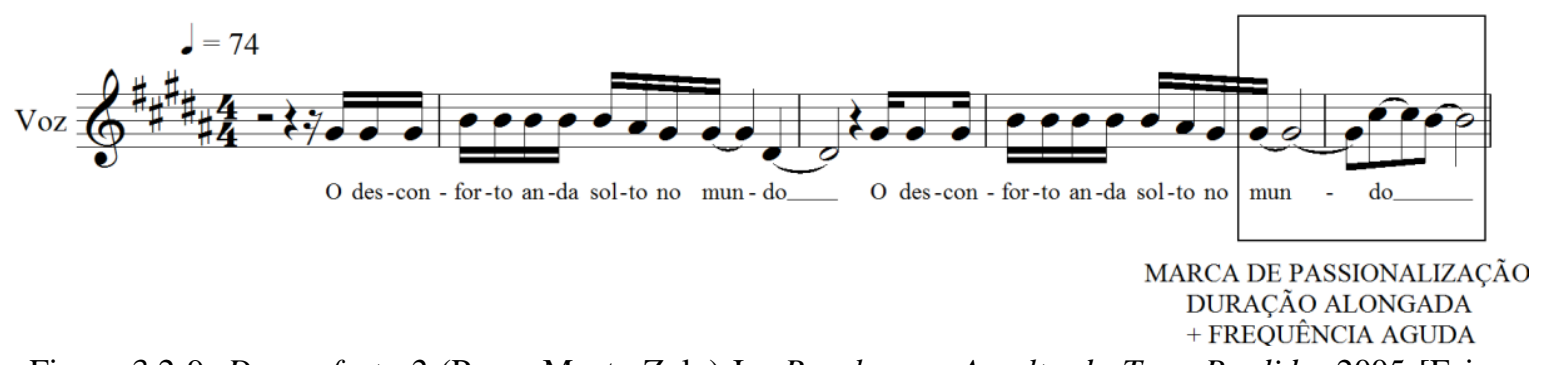

Figura 3.2-9: Desconforto 2 (Posse Mente Zulu) In: Revolusom: A volta do Tape Perdido, 2005 [Faixa 71]

Sonho meu

Até parece que foi sonho meu

Sonho meu

Como faz falta um abraço seu

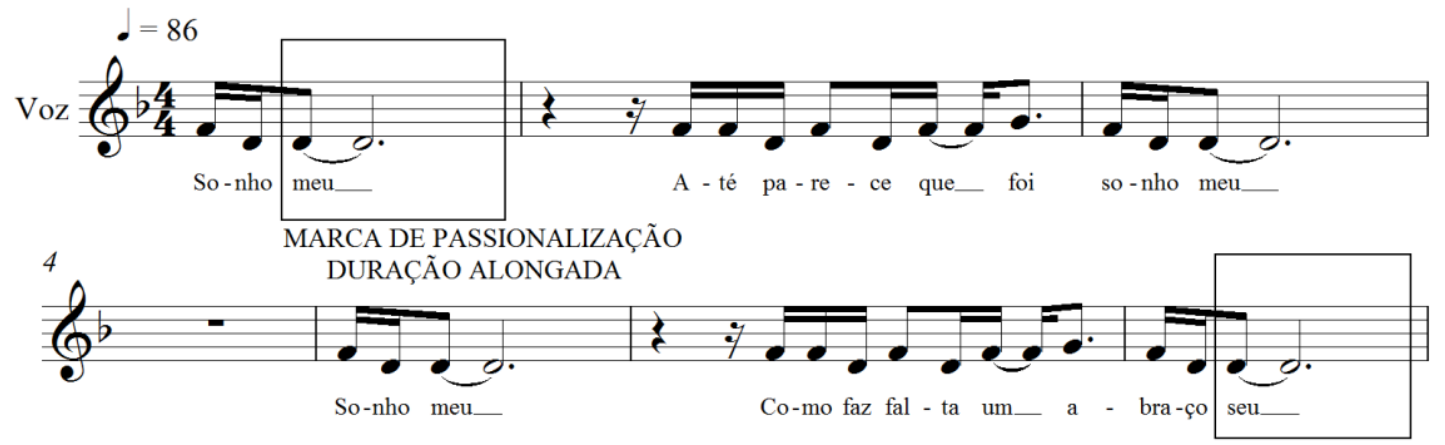

MARCA DE PASSIONALIZAÇÃO DURAÇÃO ALONGADA

Figura 3.2-10: Sonho meu (Xis) In: Fortificando a Desobediência, 2001 [Faixa 72]

Em muitas outras canções, notamos a presença de vocais femininos passionalizantes:

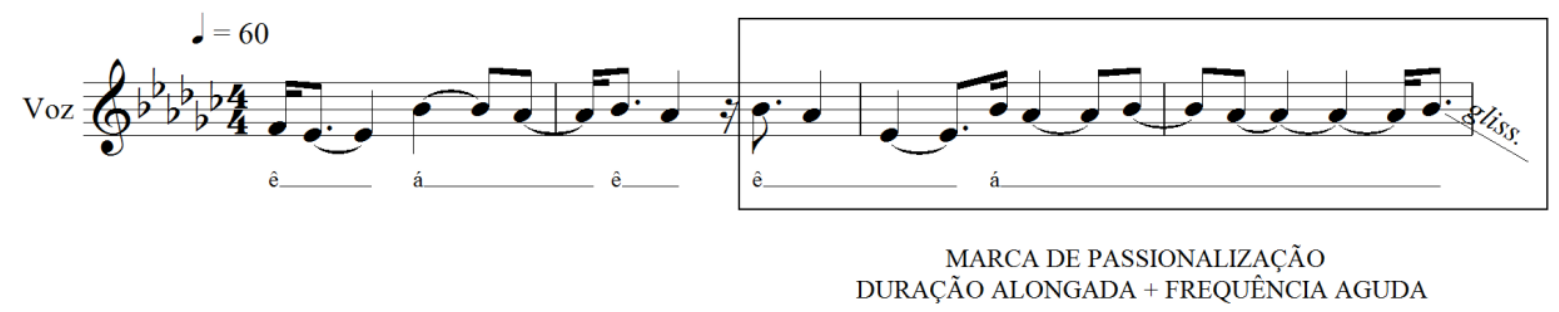

Figura 3.2-11: Brasil com “P” (GOG) In: DVD Cartão Postal Bomba, 2007 [Faixa 73]

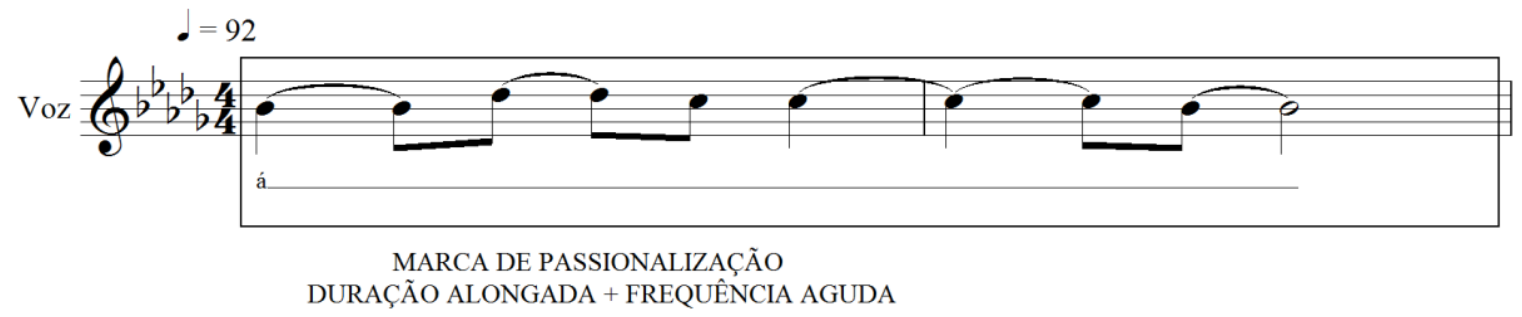

Figura 3.2-12: Deus abençoe a todos (Faces do Subúrbio) In: Faces do Subúrbio, 1998 [Faixa 74] 

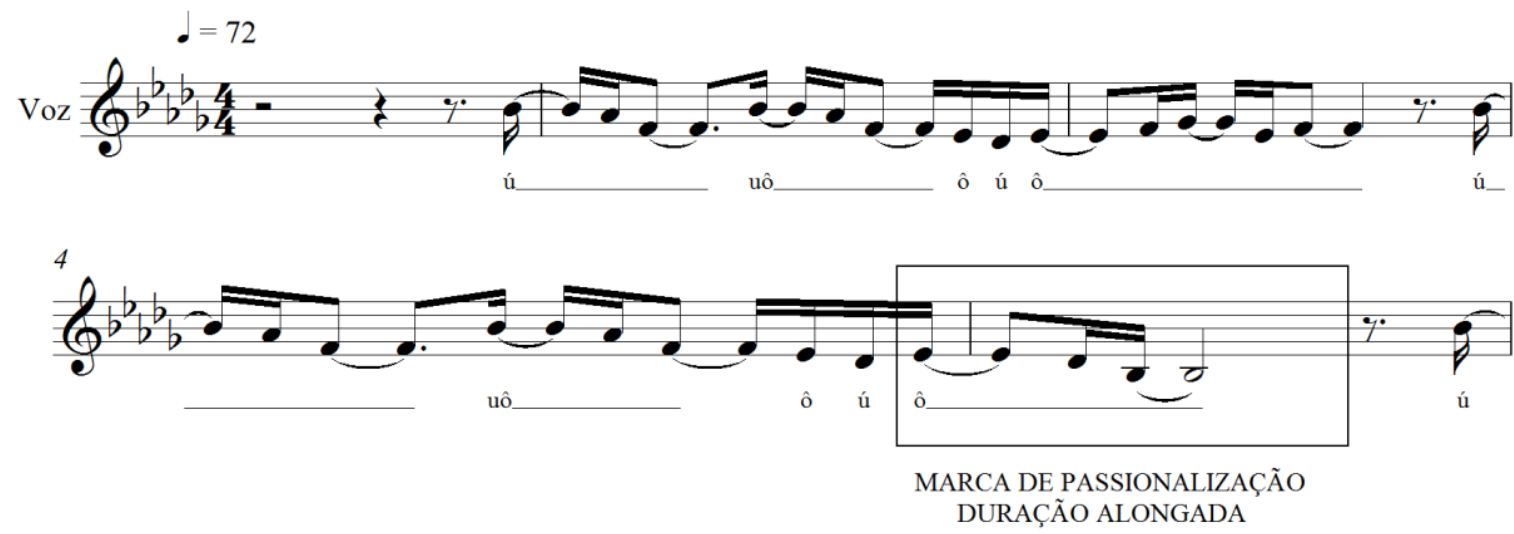

Figura 3.2-13: Noite de Insônia (MRN) In: Só se não quiser ser..., 1994 [Faixa 75]
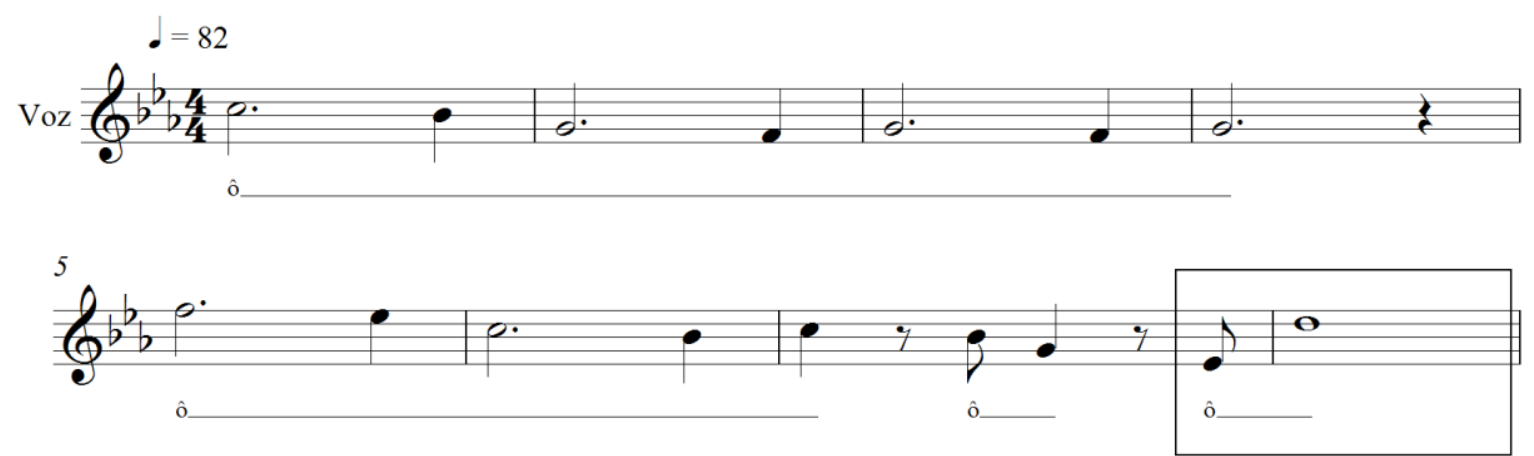

MARCA DE PASSIONALIZAÇÃO

DURAÇÃO ALONGADA

Figura 3.2-14: Soldado Morto (MV Bill) In: Retrato, 2012 [Faixa 76]

+ SALTO INTERVALAR

Também podemos verificar a inserção de canções de outros autores pertencentes a gêneros como o samba ou a soul music.

Silêncio

O sambista está dormindo

Ele foi mas foi sorrindo

A notícia chegou quando anoiteceu

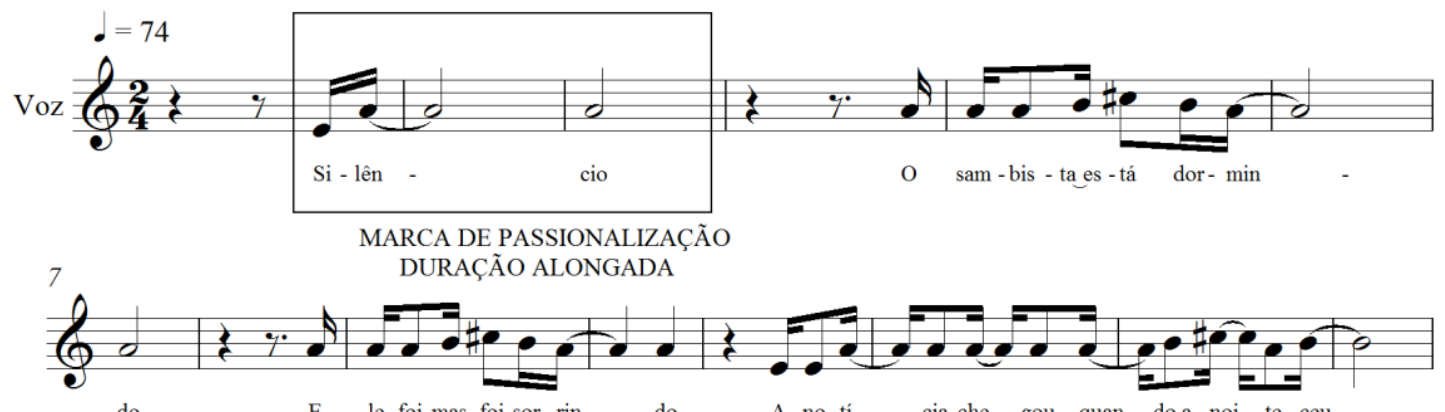

Figura 3.2-15: Silêncio no Bexiga (Geraldo Filme), canção inserida em Território Leste do grupo Consciência Humana In: CD Agonia do Morro, 2003 [Faixa 77] 
A presença desses refrãos e vocais passionais desencadeia uma importante discussão. Primeiramente, devemos destacar que todos os exemplos acima transcritos não são cantados pelos MC's, mas por cantores convidados que geralmente não fazem parte dos grupos. Por outro lado, a forma mais musical desses fragmentos contrasta fortemente com as partes interpretadas pelo rapper no seu usual canto falado e, na maioria deles, há um estilo de interpretação muito ligado aos artistas da soul music norte americana. Esses dois fatores podem gerar no ouvinte a impressão de que esses refrãos não devem ser considerados como rap. Sob essa perspectiva, o rap propriamente dito seria somente a letra entoada de maneira figurativa. Nesse sentido, a presença desses estribilhos também estaria ligada à prática das apropriações realizada pelos DJ's. Isto é, a semelhança desses exemplos (figuras 3.2-1 a 3.2-10) com canções do repertório da música negra estadunidense é tão marcante que seu papel seria equivalente à função de um sample inserido pelo DJ: ao invés de "samplear" um trecho de James Brown, outros cantores são convidados para gravar os refrãos musicalizados. Por isso, há a dificuldade em aceitá-los como rap, pois o ouvinte os identifica como uma espécie de colagem, como um elemento alienígena. Para essa pesquisa, no entanto, não interessa discutir profundamente esse tipo de controvérsia. Acreditamos que tanto a prática dos samples quanto a presença dessas partes cantadas por outros intérpretes são maneiras de incorporar na canção o universo de escuta dos rappers brasileiros (cuja formação musical é muito ligada ao repertório da black music). Logo, essa aproximação entre os dois procedimentos musicais é perfeitamente legítima. Contudo, quando ouvimos ou analisamos as canções não podemos de modo algum desconsiderar trechos musicais como os exemplificados acima. Primeiramente, porque essa característica de justaposição de elementos de outros gêneros faz parte da música do hip hop desde seu nascimento. É uma característica essencial e extremamente frequente nas canções. Assim, é possível vê-la como parte constituinte da composição ${ }^{75}$. Em segundo lugar, o interesse principal desse trabalho é analisar o rap enquanto uma prática significante ligada à canção popular. Desse modo, não podemos ignorar nenhuma parte da obra em que há relação entre melodia e letra, pois ela pode ser importante, por exemplo, no exame dos conteúdos conjuntivos e disjuntivos de determinada composição. Portanto, aqui, o interesse principal não é determinar se esses refrãos passionais são ou não rap,

\footnotetext{
${ }^{75}$ Nesse sentido, poderíamos definir o gênero como a combinação entre o canto falado e outros recursos musicais (samples, vocais, refrãos musicalizados, etc.).
} 
mas sim compreender que, inegavelmente, eles fazem parte da experiência de escuta do ouvinte.

Mas a presença da passionalização no rap vai muito além desses refrãos ou vocais femininos. Também a observamos na própria entoação do rapper, no modo como o cantor emite a melodia. Nos exemplos seguintes, as notas são mais alongadas e chegam a se estabilizar em alturas definidas de maneira mais contundente, o que diminui a presença da fala e fortalece o aspecto musical. Em $A$ sina do grupo SNJ, é o próprio MC quem entoa a melodia abaixo.

\section{Você pode}

Tem que lutar

A sina da sua vida vai decifrar

O negativismo quer me impedir

Mas o sentimento de conquista não pára

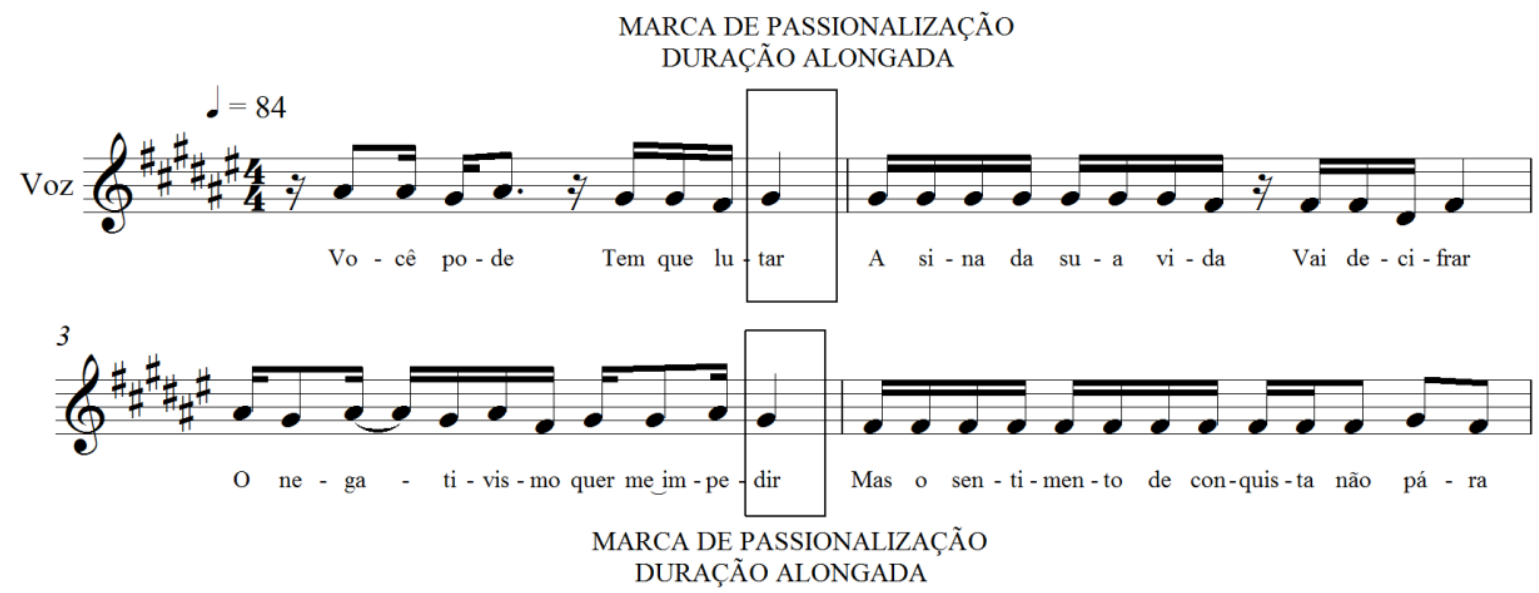

Figura 3.2-16: A sina (SNJ) In: O show deve continuar, 2003 [Faixa 78]

Nos dois exemplos seguintes percebemos algo ainda mais interessante:

Eu queria morar numa favela

Eu queria morar numa favela

Eu queria morar numa favela

O meu sonho é morar numa favela 
MARCA DE PASSIONALIZAÇÃO

MELODIA CANTADA COM POUCA ARTICULAÇÃO

- $=80$

(VALORIZAÇÃO DAS DURAÇÕES)

Voz
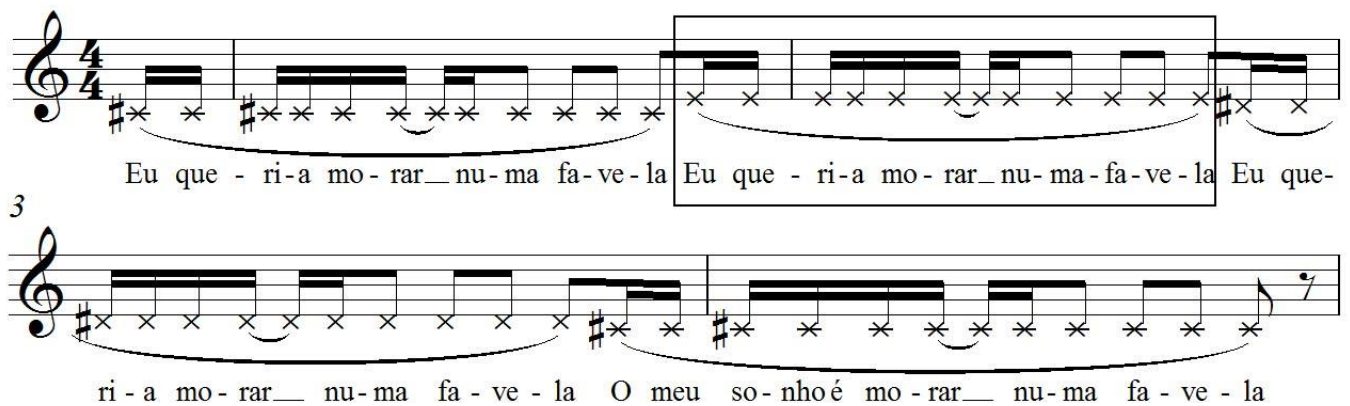

Figura 3.2-17: O resto do mundo (Gabriel O Pensador) In: Gabriel O Pensador, 1993 [Faixa 79]

Choro e correria

No saguão do hospital

Dia das criança

Feriado indo pro final

Sangue e agonia entra pelo corredor

Ele tá vivo

Pelo amor de Deus, doutor
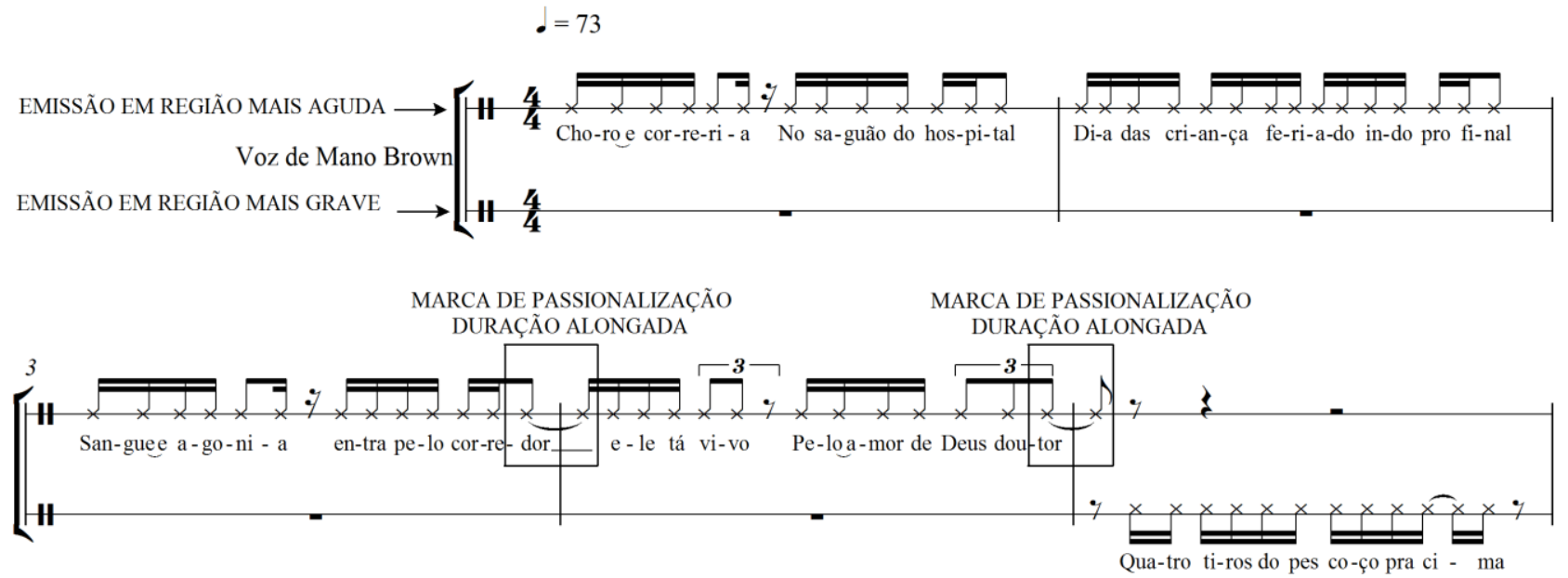

Figura 3.2-18: Fórmula mágica da paz (Racionais MC’s) [Faixa 80]

Em $O$ resto do mundo, o cantor entoa os versos de modo lastimoso e minimiza as suas articulações (seus ataques silábicos) de modo que a duração de cada nota seja valorizada. Além disso, há uma sutil variação de altura entre os versos repetidos ("Eu queria morar numa favela"), o que representa mais um fator de musicalização ${ }^{76}$. Em Fórmula Mágica da paz observamos o mesmo fenômeno. A voz de Mano Brown,

\footnotetext{
${ }^{76}$ Analisaremos essa canção adiante com maior detalhamento.
} 
igualmente plangente, se situa em uma região mais aguda e apresenta durações claramente mais alongadas. Na figura 3.2-18, a diferença de frequência pode ser facilmente notada por meio do contraste entre os quatro primeiros compassos com emissão aguda e o verso que vem em seguida, cantado em região mais grave: "Quatro tiros do pescoço pra cima". O andamento da canção é também mais lento do que geralmente observamos nas demais faixas do grupo. Essa forma musical passionalizante está absolutamente de acordo com o conteúdo da letra: choro e confusão nas dependências de um hospital onde alguém está baleado e precisando de socorro urgente. O verso "Pelo amor de Deus doutor" representa o ápice dessa carga passional, como um desesperado pedido de ajuda.

No ponto extremo desse tipo de procedimento melódico ligado à passionalização, encontramos canções que apresentam uma forma totalmente estabilizada musicalmente como, por exemplo, Não existe amor em SP do rapper Criolo. Essa obra tem seu estatuto de rap frequentemente questionado, já que não possui o canto falado característico do gênero. Como vimos, geralmente, as partes efetivamente musicalizadas e passionais das canções dos grupos de rap são curtas, como se fossem momentos excepcionais. Em Criolo, ao contrário, podem constituir a canção como um todo. Logo, na medida em que o rapper paulistano está fundamentalmente ligado ao universo do hip hop desde o início de sua carreira e que muitas faixas do seu disco são entoadas com o típico canto falado, cria-se um problema quando se tenta classificar como rap certas faixas mais musicalizadas de seu repertório. Isoladamente, essa canção dificilmente poderá ser classificada como rap. No entanto, na medida em que faz parte de um conjunto de canções ligado ao universo do hip hop, é natural que ocorra a sua aproximação em relação a esse contexto.

\section{Não existe amor em SP}

Os bares estão cheios de almas tão vazias

A ganância vibra

A vaidade excita

Devolva minha vida e morra afogada em seu próprio mar de fel Aqui ninguém vai pro céu 

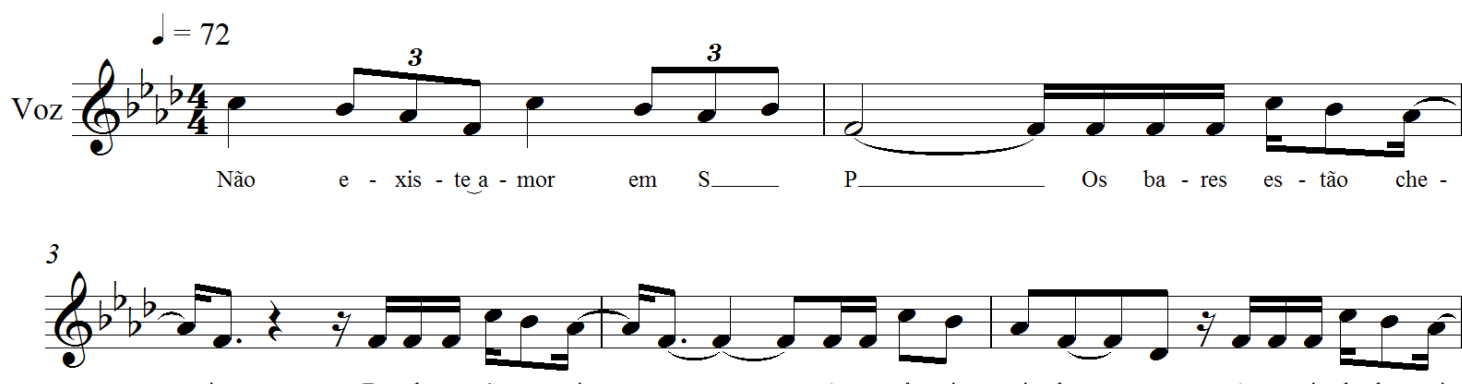

De al-mas tão va - zi

A ga-nân-cia vi - bra

A va - i-da-de e-xi-

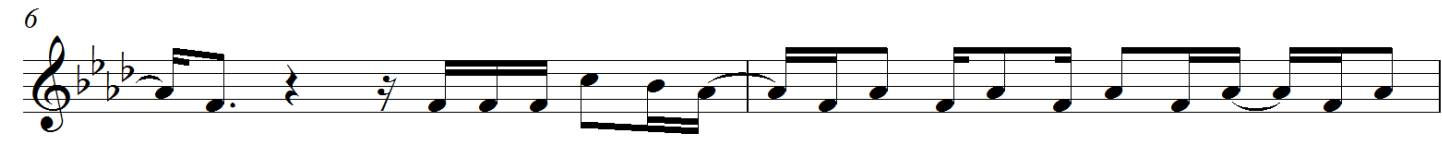

ta

De - vol - va mi - nha vi - da e mor - ra a - fo - ga - da em seu pró

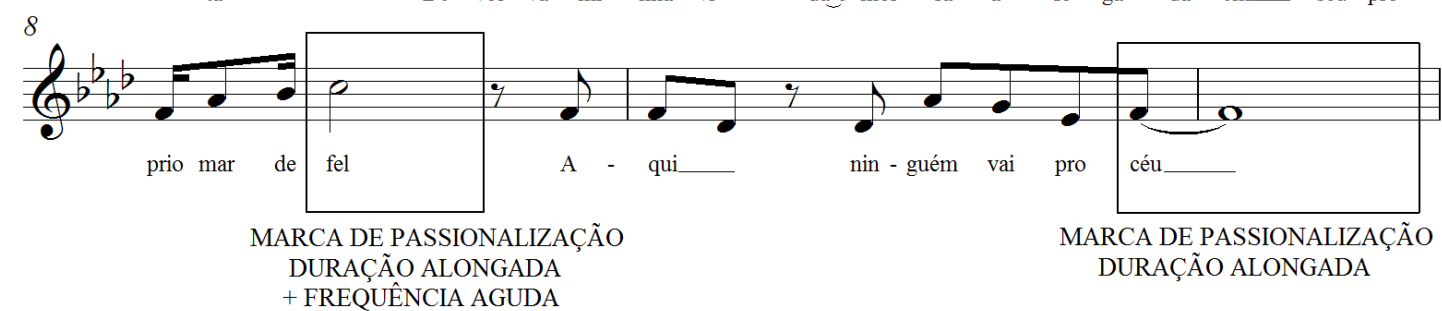

Figura 3.2-19: Não existe amor em SP (Criolo) In: Nó na Orelha, 2011 [Faixa 81]

Enfim, a presença da passionalização no rap, ainda que abrandada pela figurativização, também tem papel importante na produção de sentido. Ela é tão significativa que podemos ouvir, num mesmo disco, diversas canções que incorporam variados elementos ligados a esse recurso. Por exemplo, metade das faixas dos discos Sobrevivendo no Inferno (1998) e Nada como um dia após o outro (chora agora) (2002) do grupo Racionais MC's adota esse tipo de procedimento: no andamento desacelerado, nas linhas instrumentais, nos samples de canções inseridos pelo DJ, no canto e nos vocais passionais, sobretudo femininos. São momentos em que certos trechos melódicos apresentam uma desaceleração por meio do uso de figuras rítmicas de maior duração, uma ampliação significativa da tessitura do registro vocal e maior presença dos saltos intervalares.

Naturalmente, se há esses indícios formais de passionalização, há também conteúdos disjuntivos que os justificam. Basta citarmos os nomes das canções exemplificadas nas figuras acima e já podemos constatar que a disforia é a tônica da maioria das letras de rap. Títulos como Castelo Triste, Passaporte pro inferno, Passageiro da Agonia, Sonho meu, Soldado Morto, Desconforto 2, O resto do mundo e Não existe amor em SP já nos indicam que o assunto tratado nas canções deve girar em torno de um sujeito em disjunção com seu objeto de valor (condições dignas de vida). Nesse sentido, é relevante destacar a significativa importância do comprometimento 
social do rapper e de sua necessária legitimidade perante o público, pois nesse universo musical o compromisso com as questões sociais é algo extremamente valorizado e cobrado (ver TEPERMAN, 2011: 20-31). Ou seja, esse caráter de contestação parece estar sempre em primeiro plano. Contudo, o interessante é notar que se o estado disjuntivo tratado em grande parte das canções gera, por um lado, o caráter de revolta predominante (a denúncia social), por outro, não deixa de produzir um significativo teor de lamento. Desse modo, se a figurativização salta aos olhos como veículo mais apropriado para o protesto do $\mathrm{MC}^{77}$, a passionalização não deixa de se fazer presente, tendo em vista essa revolta ser consequência de uma situação de sofrimento agudo. Como se por trás da fala explícita houvesse sempre o choro contido.

Alguns autores chegam a discutir essa questão, embora muito rapidamente. Teperman assim destaca a pouca frequência de elementos passionalizantes do rap.

(...) o rap tende mais a descrever percursos e experiências do que traduzir estados de alma o que pode ser comprovado facilmente sobrevoando seu "cancioneiro". Podemos imaginar a parte A de "Garota de Ipanema" cantada na forma de um rap, mas nunca a parte B. $(\text { TEPERMAN })^{78}$

De maneira semelhante, Walter Garcia, em sua análise da obra Diário de um detento, dá indícios da presença de características de passionalização quando analisa certas nuances dessa canção a partir da teoria dos gêneros literários de Anatol Rosenfeld. Essa teoria delimita três modos de escrita: lírica, épica e dramática. Obviamente, trata-se de um recurso analítico ligado à literatura escrita. Contudo, podemos, ainda assim, encontrar pontos em comum em relação aos modos de compatibilização estudados por Tatit. Isto é, não há um paralelo estrito entre esses gêneros e os três processos cancionais, mas a colocação mais forte de um "eu" na lírica se aproxima, de certa maneira, dos aspectos observados na passionalização, pela presença maior da subjetividade. Enfim, desejamos resgatar trechos de análises de pesquisadores nos quais essa questão passional tenha sido de alguma forma comentada,

\footnotetext{
77 Como vimos no primeiro capítulo dedicado ao estudo da figurativização, a adoção desse recurso predomina na obra dos rappers, pois o seu propósito mais comum é o de enviar mensagens de protesto aos ouvintes e o registro da fala é o mais conveniente para esse objetivo. Assim, a desigualdade social provoca a denúncia, e essa contestação pede o uso da figurativização em detrimento dos outros processos.

${ }^{78}$ TEPERMAN, Ricardo. Se liga no som - as transformações do rap no Brasil. São Paulo, ClaroEnigma, no prelo.
} 
mesmo que muito sutilmente. Walter Garcia destaca a preponderância do gênero épico no rap:

uma obra em que a lírica mal se equilibra frente a uma épica bem acentuada, de tal forma que o lirismo aí permanece sobretudo por conta da intensidade das vivências cantadas pela voz principal (GARCIA, 2007: 180)

Os dois autores enfatizam a presença da épica, pelo fato de o rap "descrever percursos e experiências" ao invés de traduzir "estados de alma", nas palavras de Teperman. Traduzindo para a terminologia da semiótica greimasiana, diriam que as letras de rap retratam mais o momento da ação do sujeito (as modalizações do fazer) do que as qualificações modais do sujeito do estado ${ }^{79}$ (modalizações do ser). No entanto, a despeito dessa tendência épica apontada por eles, observamos que os sujeitos do discurso nas letras de rap se encontram geralmente em um estado de frustração, construindo programas e percursos narrativos caracterizados pelo fracasso, o "estado de alma" mais frequente nas letras dos MC's, para repetir a expressão utilizada por Teperman. É o que podemos observar na modalização presente na estrutura narrativa dessas canções. Aliás, esse é um fator importante para justificar o valor de passionalização presente em muitas obras. Em Homem na estrada do grupo Racionais MC's, por exemplo, o sujeito se caracteriza pela insatisfação e decepção. Ele não consegue alcançar o seu objeto de valor (cidadania), pois não possui as articulações modais ${ }^{80}$ necessárias para isso.

O programa de base do S1 (homem) é estruturado com base em um objeto de valor cognitivo, da ordem do ser, pois ele, (S1), é instaurado pela modalidade volitiva: querer ser um cidadão (...) S1 não consegue adquirir a competência para desenvolver seu programa, realizar seu desempenho, falta-lhe o saber-fazer e o poder-fazer, portanto, não há um estado de transformação e seu estado final é de disjunção com o objeto de valor, caracterizando uma narrativa do fracasso. (OLIVEIRA, 1999: 164)

Esse tipo de configuração modal é extremamente recorrente nas canções do hip hop. Fato natural tendo em vista ser um gênero sempre comprometido com os

\footnotetext{
${ }^{79}$ BARROS, 2001: 61

${ }^{80} \mathrm{Na}$ teoria da semiótica narrativa, as articulações modais modificam "as relações do sujeito com os valores" (BARROS, 2001: 50). Trata-se da análise da fase anterior à performance (a ação propriamente dita do sujeito em busca de seu objeto). Nessa fase preliminar, o sujeito passa a ter certas modalidades (querer-fazer, dever-fazer, saber-fazer e poder-fazer) que o tornam apto a conquistar o seu objeto.
} 
problemas sociais da população pobre das grandes cidades. Mas é interessante notar que os elementos de passionalização gerados por esse estado disjuntivo que predomina na maioria das letras têm raízes mais profundas na história do rap e da música negra em geral, pois os DJ's sempre se apropriaram de obras da tradição da black music para compor seus samples e o universo do rap sempre esteve intimamente ligado aos bailes black. Em São Paulo, por exemplo, no final dos anos 1960, esses bailes promovem uma revalorização da música negra, com a divulgação dos gêneros soul, funk e samba rock e de artistas como Sly \& Family Ston, Funkadelic, James Brown, Irma Thomas, Aretha Franklin, Wilson Pickett, Lady Zu, Jorge Benjor, Gerson King Combo, Tony Tornado, Tim Maia e Banda Black Rio. E ainda que a primeira manifestação do hip hop no Brasil tenha ocorrido apenas em meados dos anos 1980 com o aparecimento da dança break, sua história se inicia justamente nesse momento, a partir da popularização desses eventos musicais ligados à soul music (SANTOS, 2002: 52). Isso pode ser reconhecido facilmente quando nos debruçamos sobre o trabalho musical dos rappers da atualidade. Por exemplo, na formação musical e atuação dos DJ's.

A importância do DJ se deve ao fato de procurar na adaptação sempre a batida certa, na descoberta dos sons que melhor se harmonizam com as letras propostas, o que implica em um grande conhecimento das raízes do hip hop, funk, soul, jazz e da música negra de um modo geral (...) Os samplers que consistem numa espécie de colagens musicais dentro das músicas, isto é, uma parte tomada de alguma coisa para apresentar a qualidade do todo. São espécies de citações de outros autores e/ou cantores absorvidos na sua formação. (SANTOS, 2002: 39)

Esse conhecimento das raízes musicais reivindicado pelos DJ's nos leva a um ponto importante da história do hip hop: a sua forte ligação com outras manifestações culturais ligadas ao movimento negro. No Brasil, essa ligação se dá, sobretudo, a partir dos eventos ligados à black music.

O pesquisador João Batista de Jesus Felix propõe uma aproximação entre o movimento hip hop brasileiro e experiências do movimento negro (...) Historicamente, o vínculo mais importante, destacado por Felix, é com a experiência das equipes de bailes black, que marcaram as décadas de 1970 e 1980, na periferia de cidades como São Paulo e Rio de Janeiro (TEPERMAN) ${ }^{81}$

${ }^{81}$ TEPERMAN, Ricardo. Se liga no som - as transformações do rap no Brasil. São Paulo, ClaroEnigma, no prelo. 
Nesse sentido, ao constatarmos que a ligação do hip hop com o movimento negro se fez principalmente a partir dos bailes black, é importante resgatarmos as características de repertório musical tocado nessas festas dos anos 1970. Percebemos então a forte presença da soul music internacional e nacional, muitas vezes com canções que possuem aspectos claramente passionais.

\begin{abstract}
Em São Paulo, equipes como Os Carlos, Fórmula Um e Black Mad faziam festas na rua, em estacionamentos ou na porta de bares. Nas vitrolas, muito samba-rock, funk e soul. Equipes como Zimbabwe e Chic Show atingiram um grande nível de organização, chegaram a ter programas na rádio FM e adquiriram imóveis de grande porte para realização de suas festas. Durante anos, a Chic Show alugava regularmente o ginásio da Sociedade Esportiva Palmeiras, que comportava mais de 20 mil pessoas, para grandes bailes coroados com apresentações de artistas como Jorge Ben, Gilberto Gil, Tim Maia e, mais tarde, atrações estrangeiras como James Brown e Kool Moe Dee, o primeiro rapper norte-americano a se apresentar no Brasil. (TEPERMAN) ${ }^{82}$
\end{abstract}

Mas não são apenas artísticas as influências dos bailes de música negra dos anos 1970 no rap brasileiro. A contribuição se deu também na esfera do sistema de produção, com a divulgação e distribuição de novos artistas. Assim, além de veicular o repertório dos principais cantores de soul music, bem como os últimos lançamentos do rap norteamericano, as equipes de baile formaram também as primeiras gravadoras que acolheram a produção ainda incipiente de hip hop. É o que ocorreu, por exemplo, com o LP O som das Ruas (EPIC/CBS 1988), que contou com colaboração da equipe de baile Chic Show e teve significativa circulação no interior dos bailes black de São Paulo.

\begin{abstract}
Os bailes black - Asa Branca, Dama Xoc, Sandália de Prata, Sedinha da Vila das Belezas, Leste 1, Palácio, Esporte Ball, Clube da Cidade entre outros-, contribuíram e muito para o desenvolvimento do rap em São Paulo. Através deles, clássicos do rap norte-americano foram veiculados e concursos foram realizados. Foi também por intermédio das equipes de bailes que surgiram as primeiras gravadores independentes (SANTOS, 2002: 88)
\end{abstract}

Enfim, tais fatos são relevantes para demonstrarmos que a história do rap nacional se liga intimamente a esse movimento musical dos bailes dos anos $1970 \mathrm{e}$

\footnotetext{
82 TEPERMAN, Ricardo. Se liga no som - as transformações do rap no Brasil. São Paulo, ClaroEnigma,
} no prelo 
1980. Em termos artísticos e de distribuição. Então, seria significativo localizarmos nesse repertório da música negra os elementos passionais referidos acima, o que poderia configurar uma possível origem da passionalização no rap. Notamos que as vozes da soul music sempre valorizaram as longas durações. A tão conhecida importância do intérprete e de sua voz. James Brown, o mais importante artista do gênero, ao mesmo tempo em que apresenta um repertório dançante também interpreta canções desaceleradas e plenas de teor passional como, por exemplo, It's A Man's, Man's, Man's World, Prisoner Of Love, I'll Go Crazy, Try Me, Please, Please, Please e Lost Someone.

I lost someone

My love

Someone who's greater than the stars above

Someone who I need

Someone who don't let my heart bleed
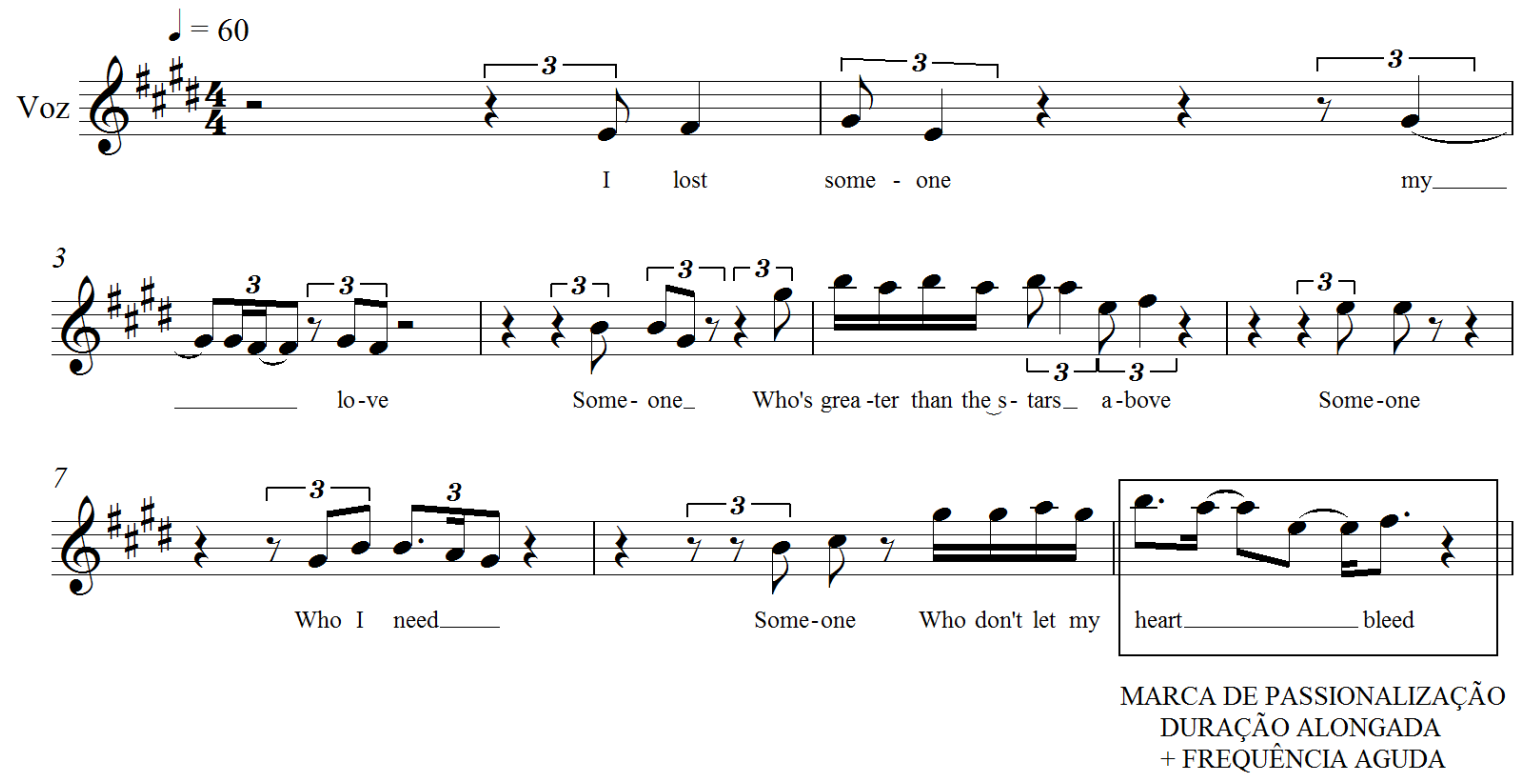

Figura 3.2-20: Lost Someone (James Brown) [Faixa 82]

Se observarmos a obra de outros cantores da soul music como Irma Thomas, Aretha Franklin, Wilson Pickett e nosso maior representante nacional do gênero, Tim Maia, veremos que esses artistas apresentam grande parte do repertório formado por canções desaceleradas e passionais, cujo conteúdo das letras gira sempre em torno das disjunções amorosas.

All my tears are in vain

I just lost lost lost my man 

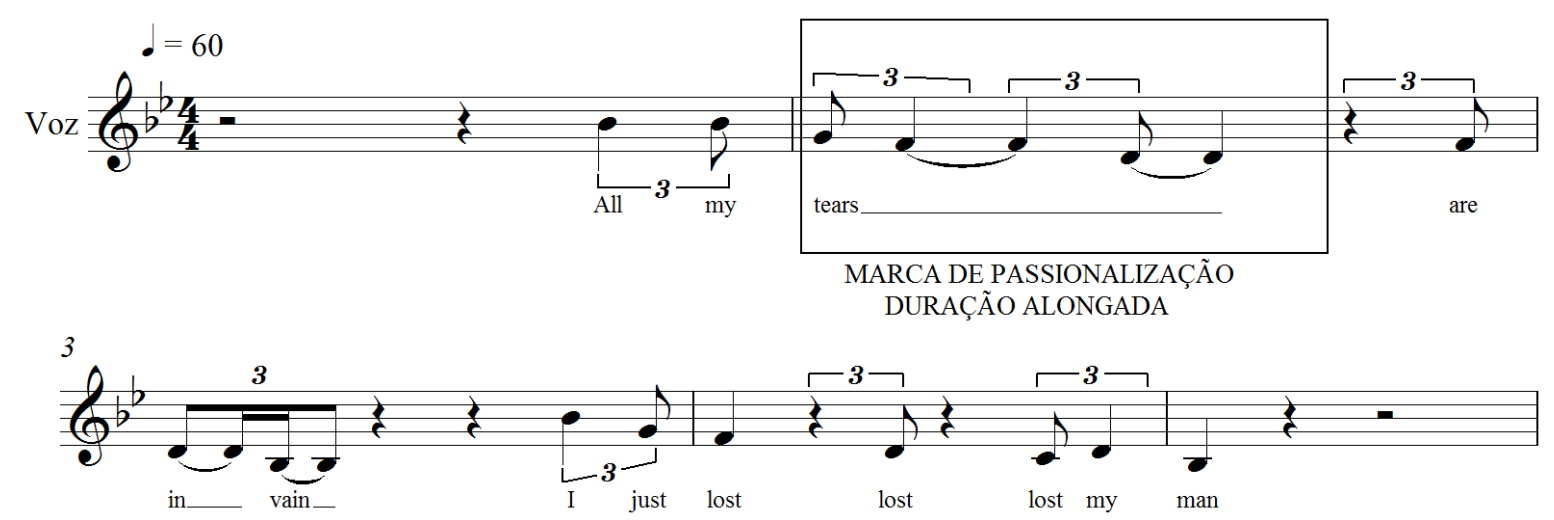

Figura 3.2-21: Cry on (Irma Thomas) [Faixa 83]

Ain't no way

For me to love you

If you won't let me

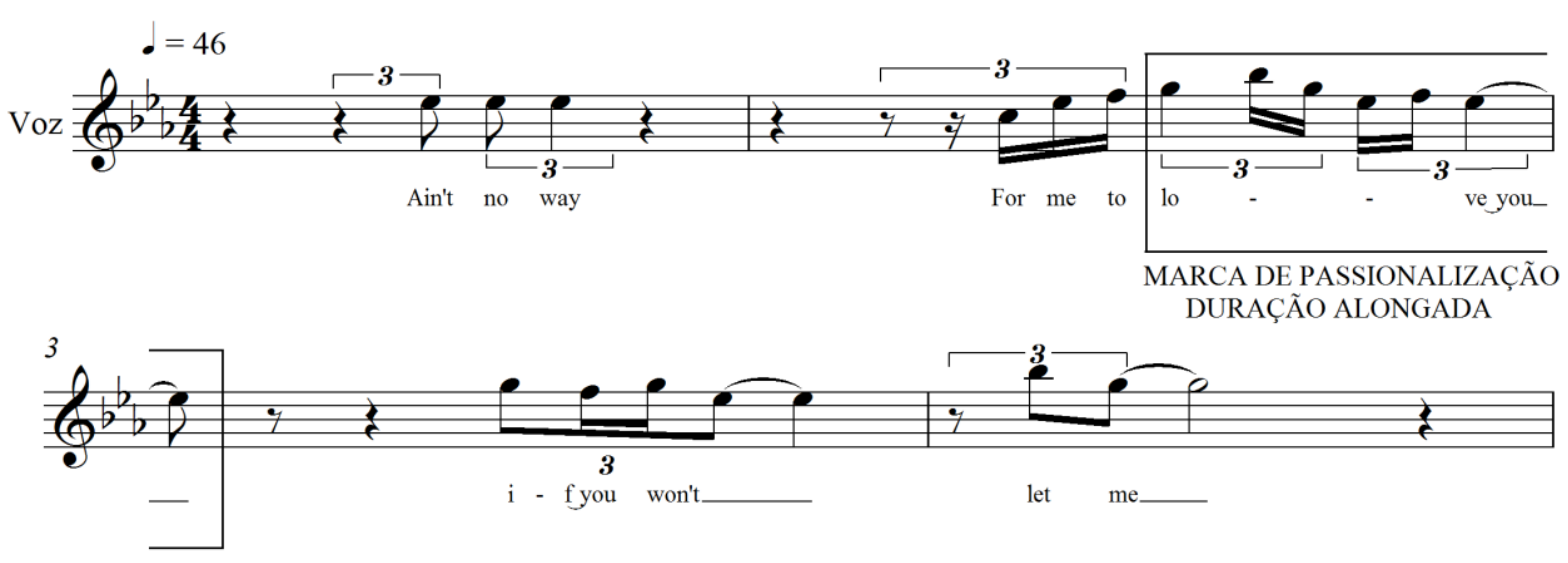

Figura 3.2-22: Ain't no way (Aretha Franklin) [Faixa 84]

It's too late to cry

It's too late to cry now

My love is gone away

MARCA DE PASSIONALIZAČ̃̃O
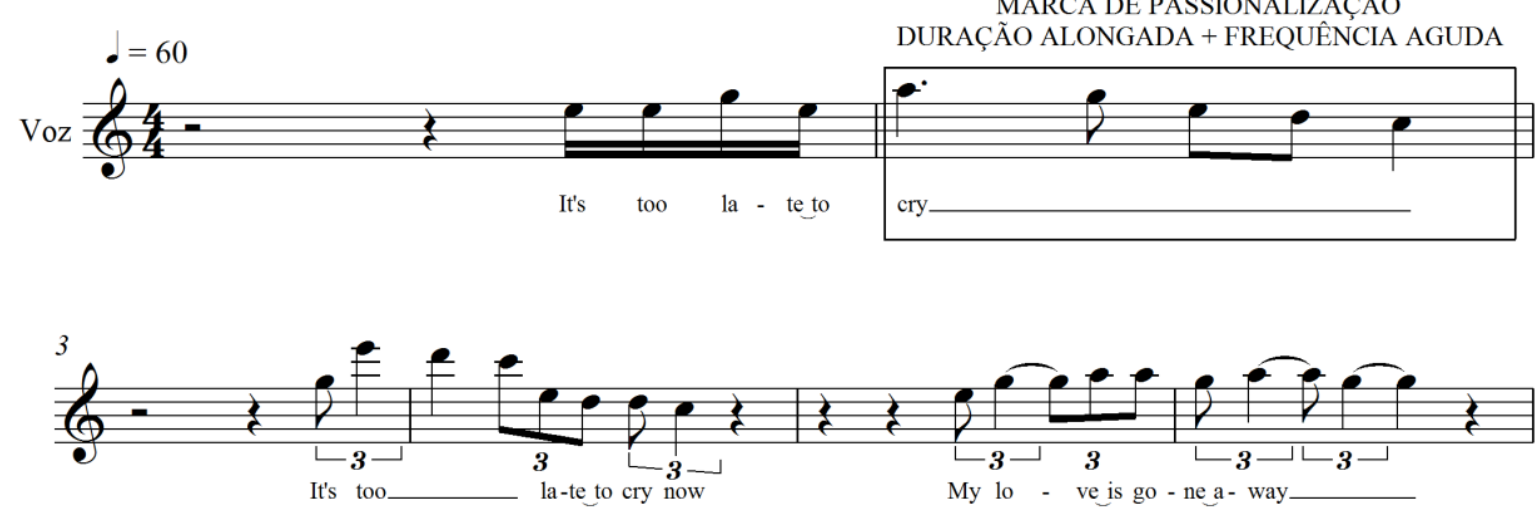

Figura 3.2-23: It's too late (Wilson Pickett) [Faixa 85] 
Estou indo embora

Não faz sentido

Ficar contigo

Melhor assim

E é nessa hora que o homem chora

A dor é forte demais pra mim
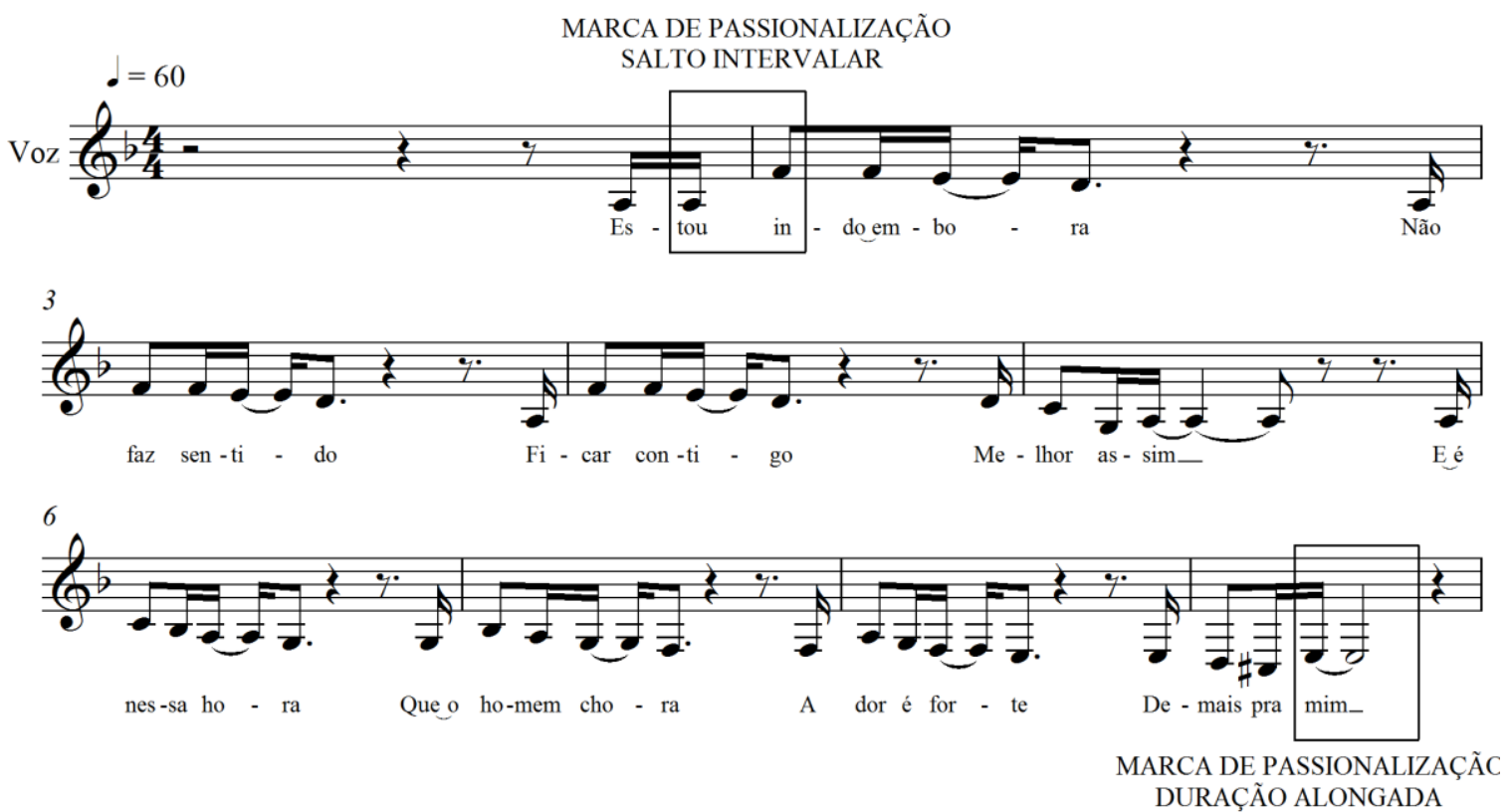

Figura 3.2-24: Me dê motivo (Tim Maia) [Faixa 86]

Essa marcante passionalização, por sua vez, tem suas raízes fundamentadas na própria origem histórica desse gênero. Segundo Hermano Vianna, o surgimento do soul está ligado à união da música profana do rhythm and blues com a música protestante negra, o gospel ${ }^{83}$, descendente do spiritual (VIANNA, 1988: 19). O rhythm and blues, por sua vez, surge nos anos 1930 e 1940 quando parte da população negra migra das fazendas do sul dos EUA para as grandes cidades do norte levando consigo a canção blues que, antes rural, se eletrifica dando origem ao novo gênero. Assim, observamos que a origem do soul remonta a gêneros em que a passionalização é muito presente como o blues e o gospel.

E apenas para destacar o quanto é significativo esse possível caminho histórico que liga o blues, o rhythm and blues, o gospel, o soul, o funk e o rap, podemos também observar esse percurso a partir de uma chave política. Conforme aponta Hermano Vianna, no final dos anos 1960 o soul já se transformara e perdera o seu ímpeto

\footnotetext{
${ }^{83}$ Vianna aponta como principais artistas responsáveis pelo desenvolvimento do soul os cantores James Brown, Ray Charles e Sam Cooke, que utilizavam até mesmo gestuais e frases comuns dos pastores protestantes durante a liturgia.
} 
revolucionário presente no início da década ${ }^{84}$, passando a ser tratado muitas vezes como um mero rótulo comercial. Assim, quando o soul é absorvido pela cultura branca e pela grande indústria, o "funky" começa a ganhar espaço e se torna um símbolo do orgulho negro, empregando ritmos e arranjos musicais mais marcados (VIANNA: 1988:20). Mas, assim como o soul, o funk também passa por um grande processo de comercialização e conquista de grande sucesso de massa ${ }^{85}$. E na medida em que ocorre esse processo de comercialização, o caráter de conscientização valorizado anteriormente se perde. Então, é justamente o rap que, ao surgir nas festas do Bronx, passa a exercer essa função de conscientização e "autenticidade" da cultura negra que teria sido perdida por esses gêneros já largamente comercializados. Portanto, notamos que o caráter contestatório do rap, de certa maneira, encontra raízes numa tradição de resistência negra já presente no soul e no funk. Todos esses estilos musicais são valorizados por esse viés de conscientização social. Mais um fator que liga a história do hip hop a essas manifestações artísticas da década de sessenta. Isso nos ajuda a compreender porque o repertório da black music norte-americana e brasileira está tão presente no universo musical do rap em geral. Nesse sentido, é interessante observarmos a canção Sr. Tempo Bom [Faixa 87] de Thaíde e DJ Hum.

\section{Sr. Tempo Bom}

Que saudade do meu tempo de criança,

Quando eu ainda era pura esperança,

Eu via minha mãe voltando pra dentro do nosso barraco,

Com uma roupa de santo debaixo do braço.

Eu achava engraçado tudo aquilo,

Mas já respeitava o barulho do atabaque,

E não sei se você sabe a força poderosa que tem na mão

De quem toca um toque caprichado, santo gosta.

Então me preparava pra seguir o meu caminho,

Protegido por meus ancestrais.

Antigamente o samba-rock, Black Power, soul,

Assim como o hip-hop era o nosso som.

\footnotetext{
${ }^{84} \mathrm{O}$ autor destaca que nos anos 1960 o soul tem papel importante para o movimento de direitos civis e conscientização dos negros norte-americanos (a canção Say it loud - I'm black and I'm proud de James Brown é um exemplo disso), o que de alguma forma também se relaciona com o caráter de conscientização valorizado pelo rap contemporâneo.

${ }^{85}$ Processo que abre espaço para o sucesso da disco music que dominaria a música negra e as pistas de dança em todo mundo no final da década de 1970.
} 
A transa negra é quem rolava as bolachas,

A curtição do pedaço era o La Croachia,

Eu era pequeno e já filmava o movimento ao meu redor,

Coreografias, sabia de cor.

E fui crescendo rodeado pela cultura Afro Brasileira,

Também sei que já fiz muita besteira,

Mas nunca me desliguei das minhas raízes,

Estou sempre junto dos blacks que ainda existem.

Me lembro muito bem o som e o passinho marcado

Eram mostrados por quem entende do assunto,

E lá estavam Nino Brown e Nelson Triunfo,

Juntamente com a Funk Cia que maravilha.

Que tempo bom que não volta nunca mais

Que tempo bom que não volta nunca mais

Que tempo bom que não volta nunca mais

Que tempo bom que não volta nunca mais

Calça boca de sino, cabelo black da hora,

Sapato era mocassim ou salto plataforma.

Gerson King Combo mandava mensagens ao seus,

Toni Bizarro dizia com razão, vai com Deus.

Tim Maia falava que só queria chocolate,

Toni Tornado respondia: Pode Crer,

Lady $\mathrm{Zu}$ avisava, a noite vai chegar,

E com Totó inventou o samba soul,

Jorge Ben entregava com Cosa Nostra,

E ainda tinha o toque dos Originais,

Falador passa mal rapaz,

Saudosa maloca, maloca querida,

Faz parte dos dias tristes e felizes da nossa vida.

Grandes festas no Palmeiras como a Chic Show,

Zimbabwe e Black Mad eram Company Soul,

Anos oitenta comecei a frequentar alguns bailes,

Ouvia comentários de lugares.

Clube da Cidade, Guilherme Jorge,

Clube Homes, Roller Super Star,

Jabaquarinha, Sasquachi, como é bom lembrar.

Agradeço a Deus por permitir,

Que nos anos setenta eu pudesse assistir, Vila Sésamo, 
Numa década cheia de emoção,

Uri Geller entortando garfos na televisão,

Dez anos de swing e magia,

Que começou com o Brasil sendo Tricampeão.

Que tempo bom que não volta nunca mais

Que tempo bom que não volta nunca mais

Que tempo bom que não volta nunca mais

Que tempo bom que não volta nunca mais

O tempo foi passando, eu me adaptando,

Aprendendo novas gírias, me malandreando,

Observando a evolução radical de meus irmãos,

Percebi o direito que temos como cidadãos,

De dar importância a situação,

Protestando pra que achemos uma solução.

Por isso Black Power permanece vivo,

Só que de um jeito bem mais ofensivo,

Seja dançando break, ou um DJ no scratch,

Mesmo fazendo grafite, ou cantando rap.

Lembra do função, que com gilete no bolso

Tirava o couro do banco do busão, uma tremenda curtição

E fazia na calça a famosa pizza.

No centro da cidade as grandes galerias,

Seus cabelereiros e lojas de disco,

Mantêm a nossa tradição sempre viva.

Mudaram as músicas, mudaram as roupas,

Mas a juventude afro continua muito louca.

Falei do passado e é como se não fosse,

Porque o que eu vejo a mesma determinação no Hip-Hop Black Power de hoje.

Que tempo bom que não volta nunca mais

Que tempo bom que não volta nunca mais

Que tempo bom que não volta nunca mais

Que tempo bom que não volta nunca mais

Essa é nossa homenagem, a todos aqueles,

Que fizeram parte ou curtiram Black Power.

Os Carlos, África São Paulo, Ademir Fórmula 1, Kaskata's,

Circuit Power, Bossa 1, Super Som 2000, Transa Funk, 
Princesa Negra, Cash Box, Musicália, Galote, Black Music,

Alcir Black Power, e a tantos outros, obrigado pela inspiração.

A letra retoma os fatos marcantes para o nascimento da cultura hip hop no Brasil. Verificamos então o quanto a cultura da black music dos anos 1970 foi fundamental para a formação dos artistas que deram início ao rap nacional. Mais um indício de que os elementos de passionalização presentes nesse estilo podem ser influência direta do repertório de canções da soul music. Nessa canção, podemos notar a presença dos três procedimentos de compatibilização entre melodia e letra. A figurativização e tematização predominantes e a presença da passionalização, ainda que mitigada.

A figurativização, obviamente, é o processo mais evidente para o ouvinte. $\mathrm{O}$ canto, sem altura definida e fortemente entoativo, aproxima-se muito da fala. No final da canção, por exemplo, quando o $\mathrm{MC}$ tece agradecimentos a personalidades importantes na história do hip hop, não temos a mesma regularidade rítmica observada anteriormente. Isto é, nesse trecho, a carga musical está ainda mais abrandada e a fala ainda mais explícita. Contudo, juntamente com a figurativização, notamos uma forte estabilização rítmica da melodia. Essa tematização melódica combina perfeitamente com o sentido da letra, pela reiteração dos nomes de personalidades e fatos marcantes que são exaltados pelo rapper, pois, como vimos no segundo capítulo, a tematização é um processo usualmente utilizado como forma de demonstrar apreço por um personagem, ideia, etc. ${ }^{86}$, geralmente com sentido de conjunção entre o sujeito e esse conceito. No caso dessa canção, há a louvação da tradição da cultura negra dos anos 1970, raiz do hip hop.

Nos trechos seguintes, por exemplo, constatamos uma construção melódica claramente tematizante e um acompanhamento instrumental que reitera esse mesmo procedimento. As divisões rítmicas são sempre regulares, o que proporciona uma identidade de motivos. Essa identidade, por sua vez, está em consonância com a vontade do rapper de materializar o universo de elementos do "tempo bom" vivido em sua infância e adolescência.

${ }^{86} \mathrm{O}$ próprio rapper deixa claro no final da canção o teor de homenagem da obra: "Essa é nossa homenagem, a todos aqueles, que fizeram parte ou curtiram Black Power". 
Que saudade do meu tempo de criança

Quando eu ainda era pura esperança

Eu via minha mãe voltando pra dentro do nosso barraco

Com uma roupa de santo debaixo do braço
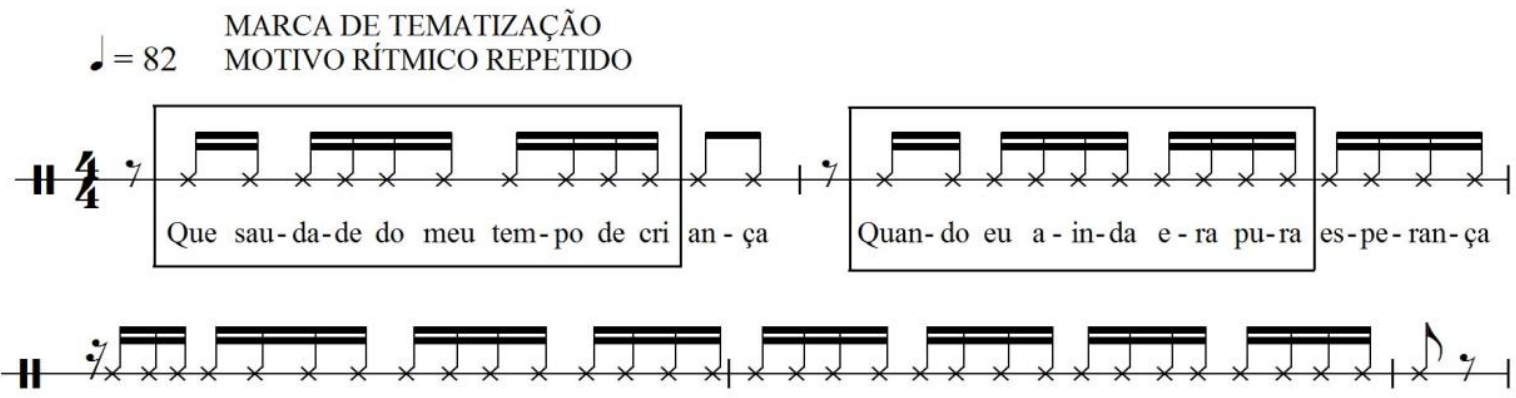

Eu vi-a mi nha mãe vol-tan-do pra den tro do nos-so bar-ra-co com u-ma rou-pa de san-to de bai-xo do bra - ço

Figura 3.2-25: Tematização melódica (regularidade rítmica) [Faixa 88]

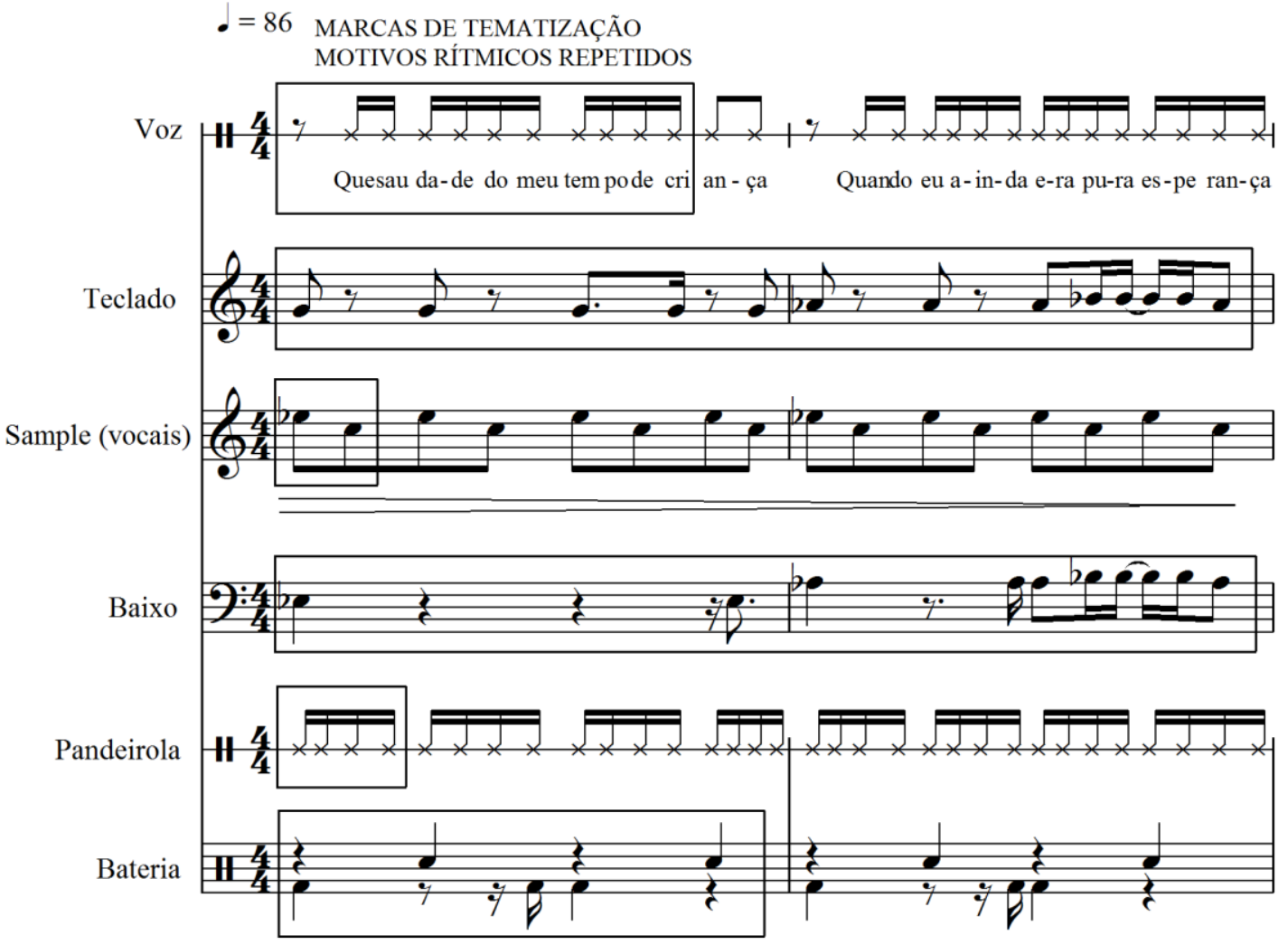




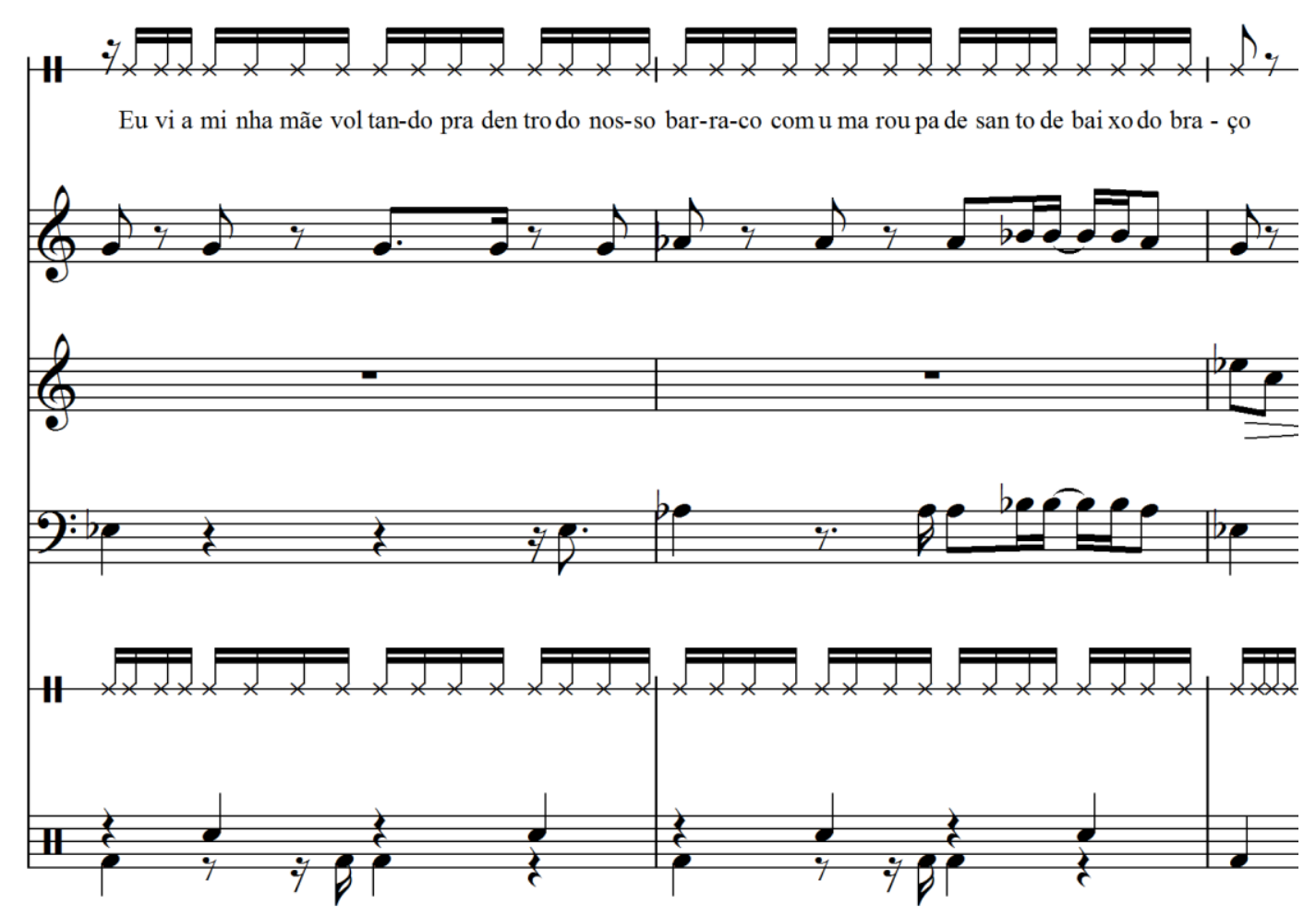

Figura 3.2-26: Tematização no acompanhamento instrumental (regularidade rítmica) [Faixa 88]

A letra exalta aspectos desse universo da black music. Observamos então a enumeração de diversos componentes do tempo da infância do rapper. São os destinadores do seu tempo bom: sua mãe, entidades do candomblé, seus ancestrais, o barulho do atabaque, os gêneros musicais (samba-rock, soul, hip hop), a cultura black power, a cultura afro brasileira, as suas raízes, as coreografias; os artistas e profissionais ligados à cultura black (Nelson Triunfo, Funk Cia, Gerson King Combo ${ }^{87}$, Tim Maia, Toni Tornado, Lady Zu, Jorge Ben, Originais, Super Som 2000), o cabelo, o vestuário (sapato mocassim, salto plataforma, calça boca de sino), as grandes festas e bailes (Chic Show, Clube da Cidade, Guilherme Jorge, Clube Homes, Roller Super Star, Jabaquarinha, Sasquachi), entidades religiosas (Deus) ${ }^{88}$, os programas de televisão (Vila Sésamo, Uri Geller), o futebol (Copa do Mundo), as gírias, a conscientização política e social, os quatro elementos do hip hop (break, grafite, DJ e rap), as brincadeiras (tirar "o couro do banco do busão, uma tremenda curtição") e os espaços da cidade (grandes galerias, cabeleireiros, lojas de discos que mantêm a tradição viva). Enfim, essa reiteração exaustiva dos componentes da cultura black dos anos 1970

${ }^{87}$ Cujo papel de destinador fica claro no seguinte verso: "Gerson King Combo mandava mensagens ao seus"

88 "Agradeço a Deus por permitir" 
combina perfeitamente com a reiteração musical do acompanhamento e a regularidade rítmica da melodia do canto.

No entanto, não obstante a figurativização e tematização predominantes, podemos notar trechos musicais em que a passionalização está claramente presente. Por exemplo, na melodia do refrão e nos vocais femininos que aparecem no decorrer da canção:

Que tempo bom que não volta nunca mais Que tempo bom que não volta nunca mais Que tempo bom que não volta nunca mais Que tempo bom que não volta nunca mais
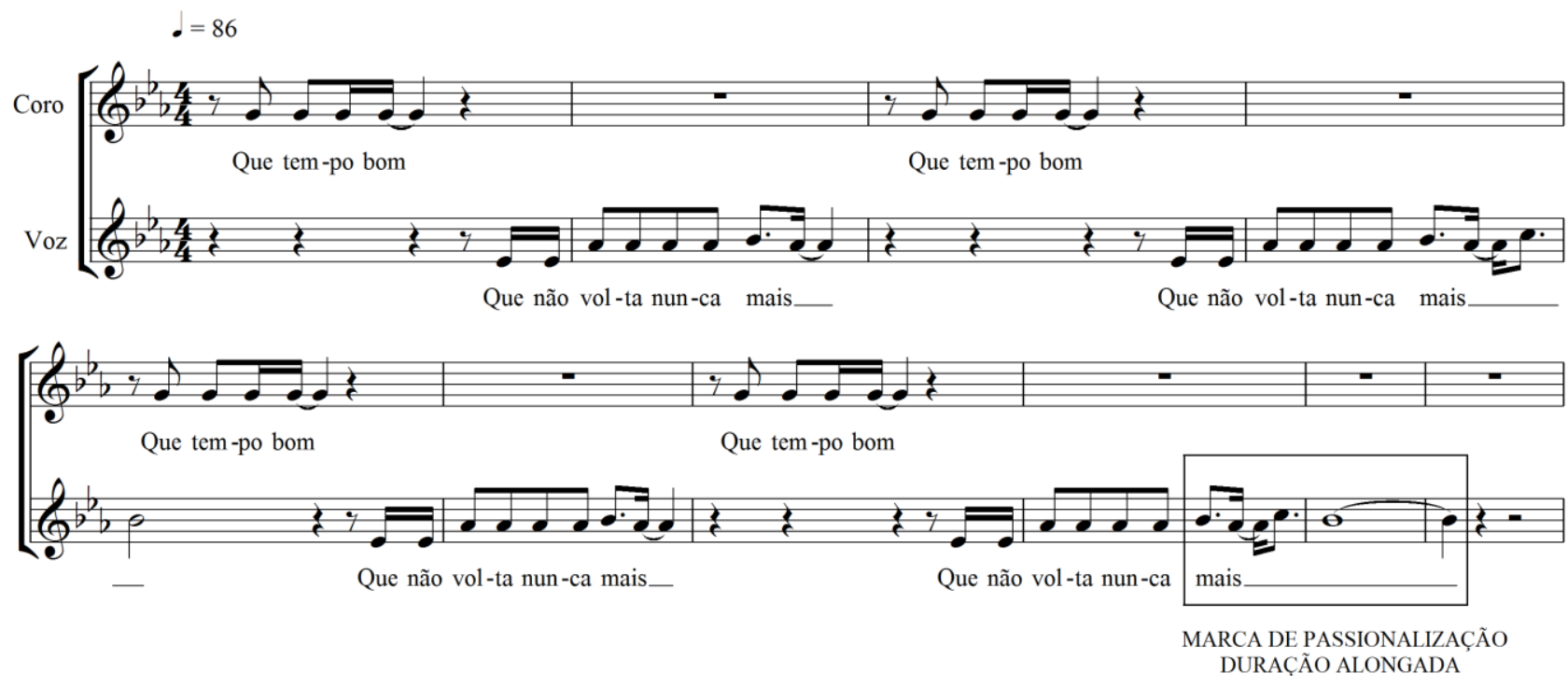

Figura 3.2-27: Passionalização na melodia do refrão [Faixa 89]

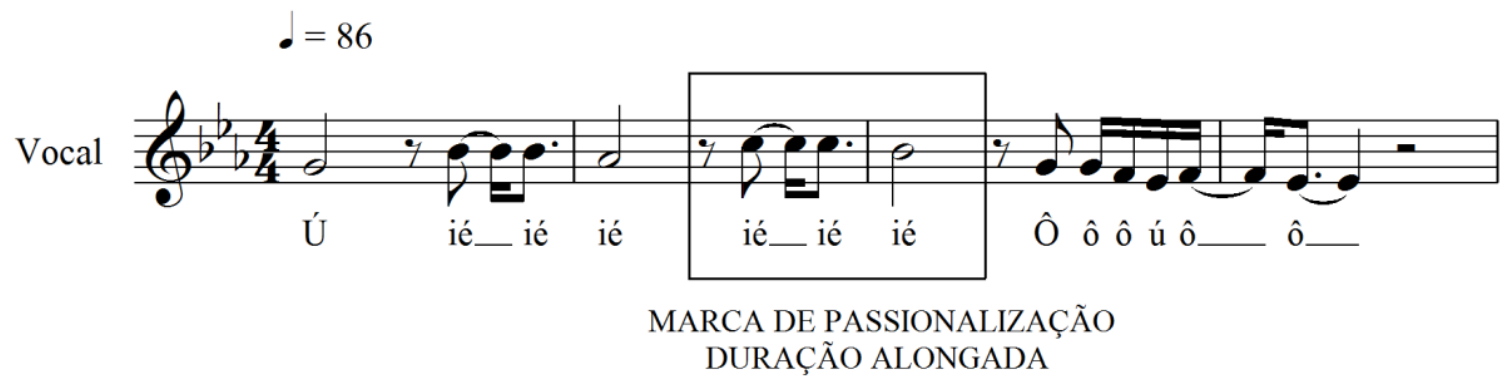

Figura 3.2-28: Passionalização nos vocais femininos [Faixa 90]

A presença da passionalização nessa obra nos indica algo interessante. Se por um lado há uma configuração de conjunção (um sujeito que canta sua ligação harmoniosa com os valores da cultura negra), por outro, notamos certo grau de disjunção já que o MC está cantando algo que não pertence mais ao seu tempo. O seu 
objeto de valor foi perdido. Há, no início da canção, a ideia de saudade ("que saudade do meu tempo de criança") e esse sentimento acaba justificando o teor de passionalização do refrão: os destinadores mencionados na letra não estão mais presentes e o tempo bom que era possível pela presença desses actantes torna-se impossível de ser revivido. É importante observar que essa ambiguidade (conjunção e disjunção) está reforçada pelo modo com que se canta o refrão. Notamos uma diferença nítida entre as duas frases que formam o estribilho, pois "Que tempo bom" é cantado por um coro de vozes femininas e a frase "que não volta nunca mais" é cantada com maior teor passional, por uma cantora solista. A primeira é mais curta e conjuntiva (já que está louvando o "tempo bom"). A segunda é significativamente mais alongada na duração e com maior carga de disjunção (pois esse tempo bom "não volta nunca mais"). Nesse sentido, torna-se muito interessante a citação da canção Saudosa maloca de Adoniran Barbosa ("Saudosa maloca, maloca querida / Faz parte dos dias tristes e felizes da nossa vida"). Nessa obra, assim como em Sr. Tempo bom, temos a disjunção do sujeito em relação ao seu objeto que ficou no passado: a maloca e o tempo bom. No samba de Adoniran há uma situação de disjunção ("Que tristeza que nós sentia / Cada tábua que caía / Doía no coração") e a memória do estado conjuntivo ("Donde nós passemos os dias feliz de nossas vidas”). Por isso essa canção permite ora uma ênfase na tematização, ora uma ênfase na passionalização ${ }^{89}$. Assim como na canção de Thaíde e DJ Hum.

Enfim, podemos notar que o rap, além da figurativização e tematização predominantes, também apresenta elementos de passionalização que se tornam importantes para o sentido final da canção. Passionalização advinda do conteúdo disjuntivo de grande parte das letras do gênero ${ }^{90}$, bem como por sua inserção dentro de uma tradição da música negra norte-americana em que as canções passionais estão sempre presentes. Observamos então que pode haver um movimento natural de restabelecimento da musicalização (menos menos) por meio do uso sutil da passionalização e não apenas pelo emprego da tematização. Curioso é que isso já poderia ser notado até mesmo no próprio funcionamento das primeiras festas do Bronx que deram origem ao hip hop que conhecemos atualmente. Nesse depoimento de Grandmaster Flash, um dos pioneiros do gênero, notamos que desde o início de sua

\footnotetext{
${ }^{89}$ Há interpretações muito distintas de Saudosa maloca: Observamos versões mais tematizantes como a gravação do grupo Demônios da Garoa e versões mais passionalizantes como a da cantora Elis Regina.

${ }^{90}$ Sobretudo no rap nacional cujo tema da maioria das letras é a precariedade da condição de vida da população pobre do país.
} 
história, o rap já contava com essa oscilação entre o ritmo e a desaceleração. Aliás, como em qualquer canção.

\begin{abstract}
De $11 \mathrm{~h}$ às $12 \mathrm{~h} 30 \mathrm{~min}$, eu tocava música hustle para as pessoas calmas que quisessem tocar o hustle ou dançar decentemente. Mas de $1 \mathrm{~h}$ até $2 \mathrm{~h} 30 \mathrm{~min}$, é bom agarrar o parceiro pois estou tocando os ritmos mais quentes. (...) Eu estabeleço a ordem de acordo com as batidas por minuto (...) Bob James era como 102 batidas por minuto e eu ia de 102 bpm para 118 (...). Então eu tocava as músicas lentas, as recordações. Depois que você sua e você está cansado, você gosta disso: "Oh, ele finalmente desacelerou" (TOOP, 2000:73) ) $^{91}$
\end{abstract}

Outra canção que também possui elementos que sugerem o restabelecimento (menos menos) diante da extinção musical é $O$ resto do mundo [Faixa 91] de Gabriel O Pensador $^{92}$. São aspectos musicais ligados à passionalização como, por exemplo, a entoação do cantor e certos trechos instrumentais. Como veremos mais adiante, são recursos justificados pela disjunção extrema do sujeito (morador de rua) com seu objeto de valor (condições dignas de vida). Mas vejamos primeiramente quais são esses elementos musicais que fazem diminuir a presença da fala.

O que primeiro chama a atenção do ouvinte é a entoação da melodia do canto, pois o MC executa a letra com um significativo tom de lamento. Inusitadamente, por se tratar de uma canção do gênero rap, o intérprete faz durar mais as vogais e abranda as articulações para deixar o canto menos marcado ritmicamente (mais "ligado", como se diz na terminologia musical). Dessa maneira, há na canção uma diminuição da carga de figurativização. A lamentação faz com que a melodia ganhe contornos mais musicais, com teor de passionalização. Por exemplo, o refrão da canção ${ }^{93}$, formado por quatro versos, apresenta uma configuração melódica estável, algo incomum no universo

\footnotetext{
${ }^{91}$ Tradução de Hermano Vianna. In: VIANNA, 1988:22

${ }^{92}$ Gabriel O Pensador tem uma presença conturbada no universo do rap brasileiro. Discute-se muito a falta de legitimidade de sua obra tendo em vista o cantor ser branco e pertencer a uma classe social economicamente superior. $\mathrm{O}$ artista nunca compartilhou do mesmo sistema de produção das rádios comunitárias e shows nas periferias e muitos artistas do hip hop não consideram rap a música cantada por ele (ver TEPERMAN, Ricardo. Se liga no som - as transformações do rap no Brasil. São Paulo, ClaroEnigma, no prelo). Compreendemos esse questionamento de modo muito natural, tendo em vista a origem e a história desse gênero, sempre ligado às reivindicações da população pobre. No entanto, se, por um lado, Gabriel não consegue provocar a mesma força contestatória alcançada pelos grupos da periferia, por outro, conseguiu contribuir de alguma maneira para a popularização do rap no Brasil, ainda que de forma menos politizada e não comprometida com as vozes da favela (o que certamente contribuiu para a sua aceitação na grande mídia). Para esta pesquisa, é muito relevante notar que ao adotar o rap como gênero de trabalho, o artista traz inevitavelmente tensões sociais para sua obra. Até mesmo o sentido final da canção pode se modificar de acordo com o intérprete que a está cantando (devido à forte identificação entre autor e público já comentada no primeiro capítulo). No entanto, aqui, mais do que analisar questões ideológicas ligadas ao rap, nos interessa, sobretudo, estudar a linguagem de sua canção.

${ }^{93}$ Usamos esse mesmo exemplo anteriormente, mas com menor detalhamento.
} 
musical do rap cuja constante remissão à fala geralmente não permite que o ouvinte perceba a estabilização das notas musicais. Mas aqui, tendo em vista o tom lamurioso do canto, as durações das notas são valorizadas e alongadas. Com isso, somos capazes de escutar uma variação em relação à altura. Observemos a figura abaixo:

Eu queria morar numa favela

Eu queria morar numa favela

Eu queria morar numa favela

O meu sonho é morar numa favela.

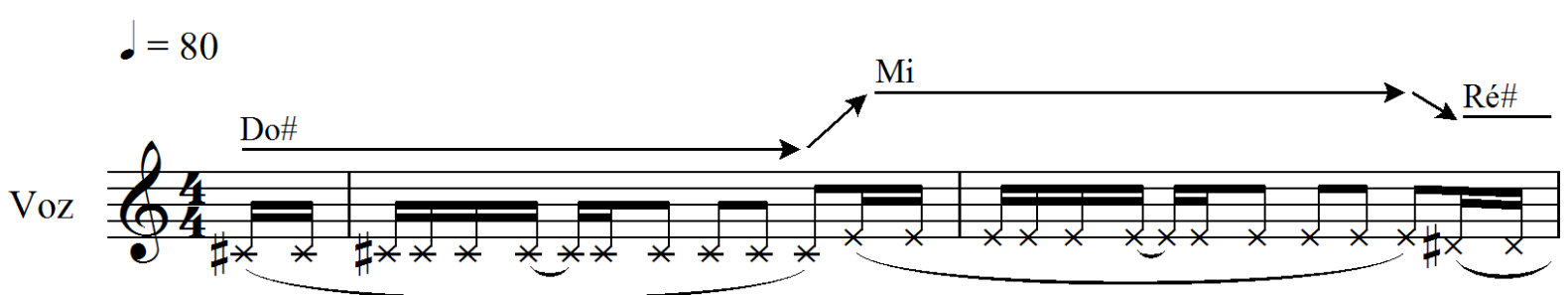

Eu que - ri-a mo-rar_nu-ma fa-ve-la Eu que - ri-a mo- rar_nu-ma-fa-ve-la Eu que-

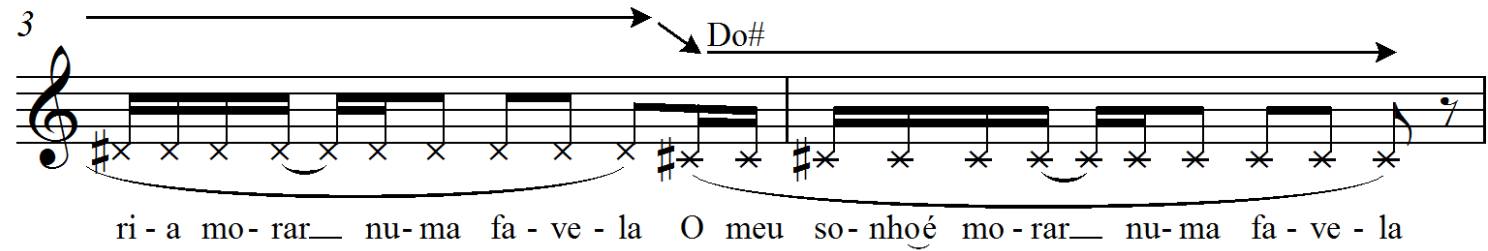

Figura 3.2-29: Passionalização no refrão de $O$ resto do mundo (Gabriel O Pensador) ${ }^{94}$ [Faixa 79]

O primeiro verso do refrão parece se estabilizar na nota Dó\#. Há algumas oscilações entre notas vizinhas, mas a frase está predominantemente construída a partir dessa altura. $\mathrm{O}$ interessante aqui é notar que há um percurso muito musical na entoação desse refrão: a segunda frase sobe para a nota Mi; em seguida, desce para a nota Ré\# e finalmente se resolve na nota inicial, Dó\#. Ou seja, observamos aqui uma estruturação musical que podemos presenciar em diversos gêneros de canção: frase inicial (estabilidade na nota Dó\#) > ascendência com nota mais aguda gerando uma tensão a ser resolvida $(\mathrm{Mi})>$ descendência e resolução dessa tensão na nota inicial (Ré\# e em seguida Dó\#). Esse tipo de procedimento é incomum no rap, cuja melodia do canto geralmente se mantém mais próxima da entoação da fala, sem valorizar as alturas ou desenhar contornos melódicos mais amplos.

\footnotetext{
${ }^{94}$ In: CD Gabriel O Pensador (1993).
} 
Há outros aspectos em $O$ resto do mundo que também atuam nesse mesmo sentido, a partir da valorização de recursos musicais. Observamos que essa canção tem uma melodia predominantemente cantada entre as notas Mib e Fá.

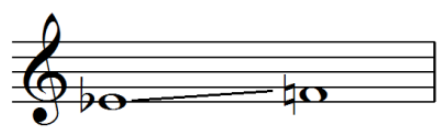

Figura 3.2-30: Tessitura predominante do canto de $O$ resto do mundo

Entretanto, na estrofe transcrita abaixo, a melodia passa a ser realizada em uma região mais aguda, localizada entre as notas Sol\# e Lá\#. Ou seja, para enfatizar o infortúnio do eu-lírico da letra, o canto sobe significativamente no que diz respeito à altura das notas. Nesse momento, em que é mais forte o desespero do sujeito (quando se dirige a Deus), a melodia alcança as notas mais agudas da tessitura.

Deus, me diga por quê?

Eu sei que a maioria do Brasil é pobre

Mas eu não chego a ser pobre eu sou podre!

Um fracassado

Mas não fui eu que fracassei

Porque eu não pude tentar

Então que culpa eu terei?

Quando eu me revoltar quebrar queimar matar

Não tenho nada a perder

Meu dia vai chegar

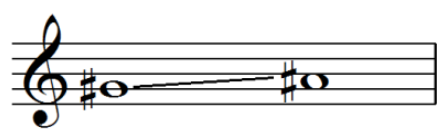

Figura 3.2-31: Tessitura mais aguda do canto em $O$ resto do mundo

Mas além do teor mais musical da melodia da voz, também notamos nesse rap a presença de trechos da parte instrumental fortemente passionalizantes. Por exemplo, no início da canção, enquanto o MC executa o refrão, escutamos simultaneamente uma melodia de sintetizador (com timbre de instrumentos de cordas friccionadas) cujas notas apresentam maiores durações e tessitura de uma oitava (Sib2 ao Sib3). 


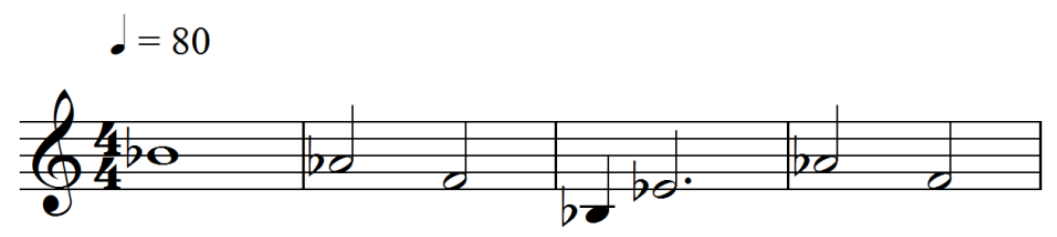

Figura 3.2-32: Melodia instrumental (Sib 2 ao Sib3) [Faixa 92]

Da mesma maneira, no decorrer de toda a obra, há outra melodia instrumental composta por notas longas que igualmente estabelece uma tessitura de oitava (dessa vez do Mib3 ao Mib4).

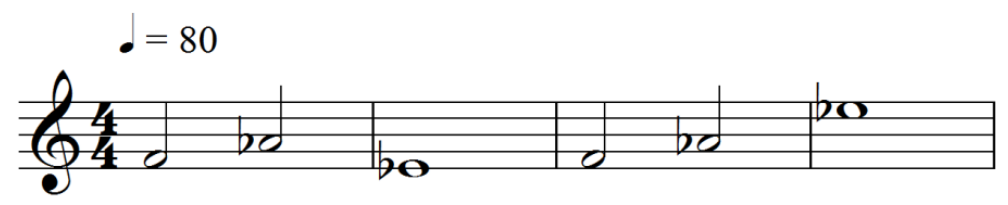

Figura 3.2-33: Melodia instrumental (Mib3 ao Mib4) [Faixa 93]

Essas duas melodias instrumentais conferem ao arranjo desse rap um caráter ligado à passionalização, já que exploram amplas tessituras a partir de notas de longa duração temporal. Mas a melodia instrumental de maior teor passional é aquela realizada por um saxofone (possivelmente um sintetizador que simula o instrumento acústico). Aqui, o caráter de passionalização é ainda mais marcado, pois a melodia se apresenta em região bem mais aguda (nota Fá4), além de ser executada com intensidade forte e com um recurso timbrístico diferenciado: as notas são articuladas com uma espécie de frulatto, resultando em um timbre mais estridente e rugoso.

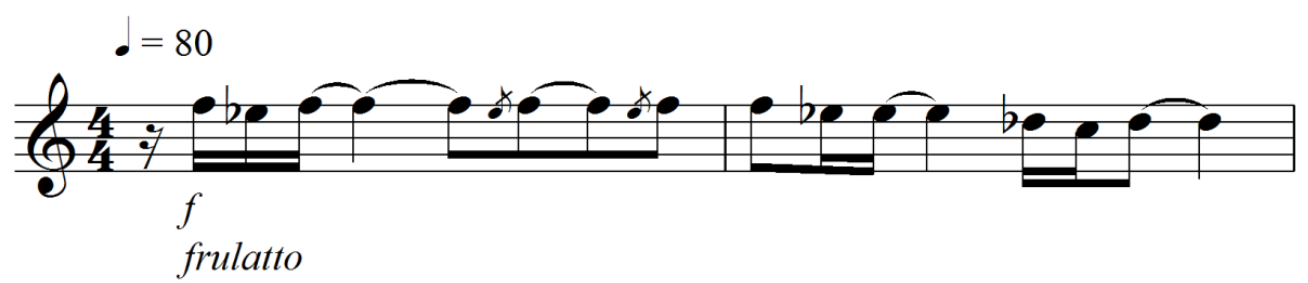

Figura 3.2-34: Melodia do saxofone [Faixa 94]

Após destacar esses recursos passionalizantes que representam, como foi dito acima, um restabelecimento musical ("só menos" > "menos menos"), vejamos o conteúdo da letra que justifica essa configuração sonora. Mais uma vez, para analisar esse aspecto, é fundamental recorrermos à semiótica tensiva, pois as quantificações subjetivas são importantes para que possamos apreender a sutileza da situação retratada 
em $O$ resto do mundo. Temos aqui uma oscilação tensiva entre níveis de condição de vida do sujeito. Entre graus diferenciados de pobreza. O personagem da canção se apresenta num estado de extinção ("só menos"). Vive uma disjunção extrema com a dignidade humana. E seu desejo de "morar numa favela" representaria então o restabelecimento de sua condição de vida extinta, o abrandamento de sua pobreza aguda.

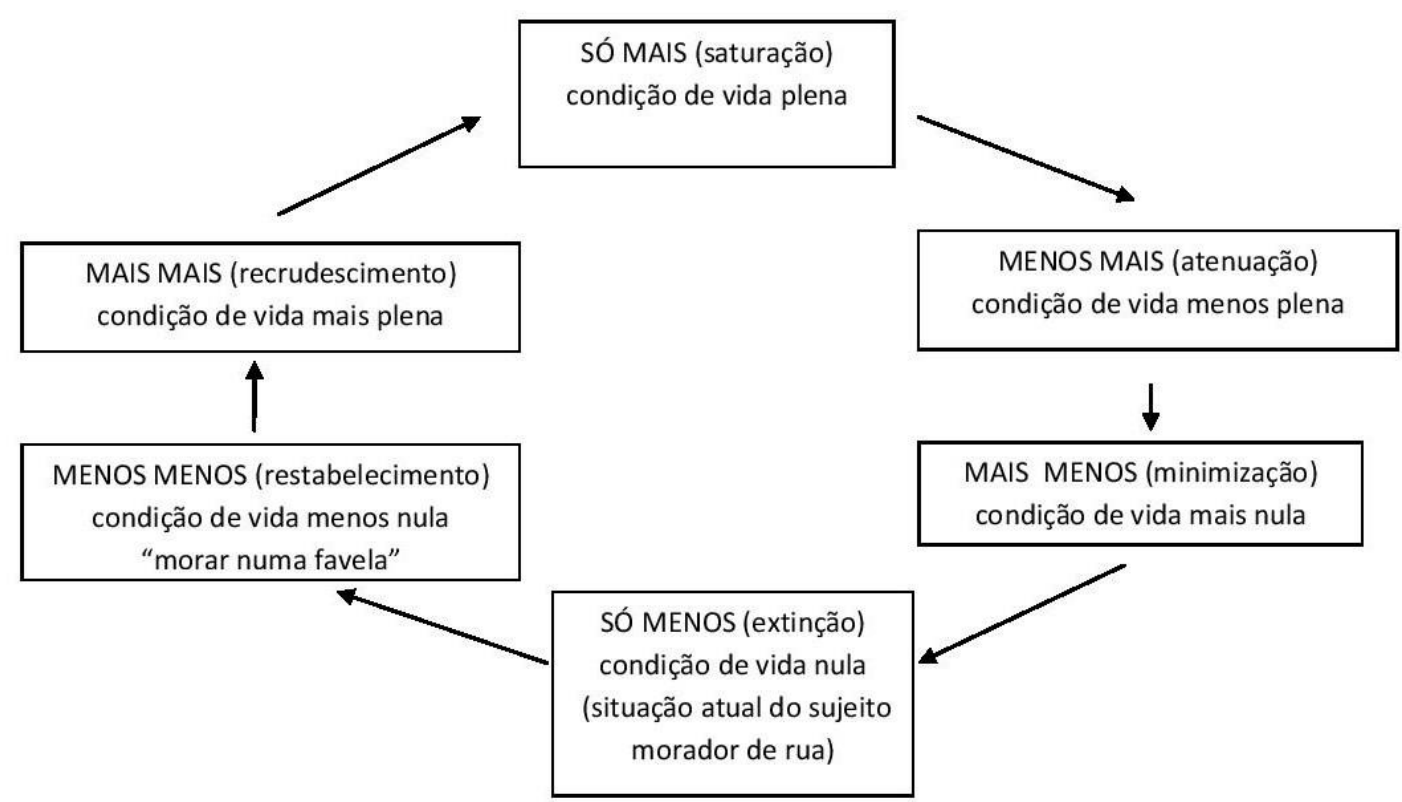

Figura 3.2-35: Oscilação tensiva entre os níveis da condição de vida do sujeito

São muitos os elementos na letra que nos indicam essa situação de extinção, pois o indivíduo se caracteriza, sobretudo, pela falta extrema. Seguem indícios dessa ausência total de condições mínimas de vida.

Eu não tenho nome

Eu não tenho identidade

Eu não tenho nem certeza se eu sou gente de verdade

Eu não tenho nada

O indivíduo se coloca numa posição em que perde características humanas para assumir uma posição animalizada. Colocado numa situação ainda mais extrema de falta, o personagem além de ser igualado a um animal é, em seguida, comparado a um objeto que representa o extremo dessa sua condição descartável: papel higiênico usado. 
Mas isso é impossível pra quem come o entulho

Misturado com os ratos e com as baratas

E com o papel higiênico usado

Nas latas de lixo

Eu vivo como um bicho ou pior que isso

O verso "A minha sina é suportar viver abaixo do chão" sugere novamente, além de uma situação que enfatiza o excesso de pobreza, a ideia do indivíduo habitar o mesmo espaço dos animais citados na estrofe acima (ratos e baratas) e de ser igualado ao esgoto que ocupa o subterrâneo da cidade. Esse aspecto de podridão, presente no papel higiênico usado e na referência aos dejetos humanos, reaparece novamente na estrofe seguinte:

Eu sei que a maioria do Brasil é pobre

Mas eu não chego a ser pobre eu sou podre!

Eu não tenho dignidade ou um teto pra morar

E o meu banheiro é a rua

E sem papel pra me limpar

Uma estrofe importante da canção, no sentido de enfatizar essa falta extrema do sujeito em relação aos valores da sociedade, é a seguinte.

Eu não sou registrado

Eu não sou batizado

Eu não sou civilizado

Eu não sou filho do Senhor

Eu não sou computado

Eu não sou consultado

Eu não sou vacinado

Contribuinte eu não sou

Eu não sou comemorado

Eu não sou considerado

Eu não sou empregado

Eu não sou consumidor

Eu não sou amado

Eu não sou respeitado

Eu não sou perdoado 
E também sou pecador

Eu não sou representado por ninguém

Eu não sou apresentado pra ninguém

Eu não sou convidado de ninguém

E eu não posso ser visitado por ninguém

Nessa sequência numerosa de negações, o sujeito aparece totalmente excluído da sociedade em diversas esferas: na esfera oficial (não é registrado, não é computado); na esfera econômica (não é contribuinte, não é empregado, não é consumidor); na esfera das relações humanas (não é civilizado, não é consultado, não é comemorado, não é considerado, não é amado, não é respeitado); na esfera religiosa (não é batizado, não é filho do Senhor, não é perdoado). No campo religioso temos a única afirmação da estrofe que, no entanto, reitera todas as negações que incidem sobre o sujeito: um pecador sem possibilidade do perdão.

Se por um lado verificamos na letra a caracterização da extinção da condição de vida, pela ausência de todos esses aspectos ligados à dignidade humana, por outro, há na canção um movimento de tentativa de restabelecimento do valor social do sujeito. $\mathrm{O}$ indivíduo passa a desejar "menos menos". É relevante destacar que seu desejo se dá no campo do mínimo possível. Numa tentativa desesperada de diminuir a sua miséria extrema.

Eu gostaria de ter um pingo de orgulho

Eu queria morar numa favela

O meu sonho é morar numa favela

O personagem deseja somente um pingo de orgulho. Ou seja, quer apenas o mínimo do mínimo. Em termos semióticos, ele se contenta com "menos menos" como forma de se restabelecer de sua condição precária. Morar numa favela para esse sujeito representa então esse restabelecimento, pois sua situação social estaria abaixo das condições de um morador pobre. Da mesma maneira, ao chamar o ouvinte de "amigo" o personagem parece pedir um pingo de amizade, uma companhia mínima que ele não possui. Vivendo em extrema falta de companhia, clama por esse "menos menos": "Eu sei que eu não tenho ninguém pra dividir o barraco comigo, mas eu queria morar numa favela, amigo". 
É também interessante analisarmos os dois estribilhos dessa canção. Podemos notar que os dois aspectos tratados acima (a caracterização da extinção das condições de vida da personagem e a sua tentativa de se restabelecer dessa situação miserável) formam o conteúdo da letra de cada um deles. Assim, o primeiro refrão apresenta um desejo de restabelecimento da extinção:

Eu queria morar numa favela

Eu queria morar numa favela

Eu queria morar numa favela

O meu sonho é morar numa favela.

Enquanto o segundo refrão destaca a ideia da extinção das condições de vida.

Eu sou o resto do mundo

Eu sou mendigo um indigente um indigesto um vagabundo

Eu sou o resto do mundo

Eu não sou ninguém

Observamos então, no tema dos dois estribilhos, a importância dessas duas ideias para a canção: extinção das condições mínimas de vida e tentativa de restabelecimento. E esses refrãos, construídos a partir da tematização melódica, geram no ouvinte a ideia de recorrência.

O destinador locutor comunica uma canção cuja melodia apresenta um comportamento reiterativo e regular. Um traço de significado pode, então, ser destacado: a periodicidade, ou seja, o caráter cíclico da melodia que sempre retorna ao mesmo ponto. (TATIT, 1986: 52-53)

O caráter reiterativo, advindo da presença dos refrãos em diversos momentos da canção, bem como a própria estrutura interna de cada um (que já é por si só repetitiva), serve para enfatizar uma situação sem solução que se repete sem perspectivas de saída ou melhora. O caráter cíclico apontado por Tatit no fragmento acima, condiz perfeitamente com a situação insolúvel do morador de rua. Há a falta de perspectivas e o 
consequente aprisionamento do sujeito em uma situação hostil da qual ele não consegue se livrar ${ }^{95}$ :

A minha vida é um pesadelo e eu não consigo acordar

E eu não tenho perspectivas de sair do lugar

Meu dia vai chegar

Será que vai chegar?

Mas por enquanto eu sou o resto

Além da minha triste sobrevivência eu tento entender a razão da minha existência

Por que que eu nasci?

Por que eu tô aqui?

Um penetra no inferno sem lugar pra fugir

Frustração

É o resumo do meu ser

Eu sou filho da miséria e o meu castigo é viver

Dessa maneira, pudemos observar que além da figurativização predominante, $O$ resto do mundo também traz elementos de passionalização e tematização (no caso da reiteração observada nos refrãos) muito significativos. Vimos, por outro lado, que esses elementos musicais (que representam um abrandamento da extinção musical) atuam sempre em consonância com o conteúdo da letra. Isto é, o conteúdo de disjunção extrema do sujeito em relação às condições de vida mais dignas justifica, na forma sonora adotada pelo rapper, os diversos elementos de passionalização: a entoação da melodia do canto com um tom de lamento (quando o intérprete faz durar mais as vogais e abranda as articulações para deixar o canto menos marcado ritmicamente); a variação na altura das notas com que o MC canta cada estrofe, quando sublinhamos a ascendência da frequência numa estrofe de maior carga passional ("Deus me diga por quê?...”); e os trechos instrumentais marcadamente passionais, sobretudo a frase

95 Como vimos anteriormente, geralmente, a forma de caráter reiterativo dos refrãos nas canções populares corresponde a uma conjunção do sujeito com seu objeto no plano do conteúdo. Aqui, também poderíamos justificar essa reiteração sob essa perspectiva. Não pela conjunção propriamente dita (já que o sujeito está em disjunção extrema com seu objeto de valor), mas sim por um possível "desejo de conjunção", como se o sujeito pudesse viver antecipadamente uma conjunção que está colocada no futuro. 
melódica executada pelo saxofone que, além de explorar uma frequência aguda, apresenta uma intensidade forte, articulando as notas com o recurso do frulatto.

Algo ainda mais interessante pode ser observado na canção Negro drama [Faixa 52] do grupo Racionais $M C$ 's ${ }^{96}$. Também encontramos elementos musicais que minimizam a presença predominante da figurativização e aspectos de passionalização muito significativos na própria melodia do MC que representam um restabelecimento diante da extinção musical. Vejamos.

Nessa canção, temos uma divisão em duas partes, a primeira cantada por Edy Rock e a segunda por Mano Brown. Essa segmentação estrutura a obra e tem grande importância para a construção de seu sentido. Assim, algo que nos chama a atenção desde a primeira escuta é a diferença entre as interpretações dos dois rappers. Ambas são fortemente expressivas, mas a partir de propostas interpretativas diversas ligadas à especificidade da letra em cada uma das partes, como veremos adiante. A voz de Edy Rock é mais grave. Embora incisiva, sua dicção é mais calma. Suas frases são mais pausadas. Percebemos uma raiva acumulada. Já em Brown sentimos essa raiva transbordando. Sua voz é mais aguda, tensa e intensa. O seu envolvimento com a letra o faz chegar ao limite da voz. Por exemplo, observamos diversos momentos em que a sua emissão possui um timbre distorcido, talvez pela maior intensidade com que a realiza. Há uma mistura de dor, raiva e orgulho que torna sua interpretação extremamente expressiva e convincente. Nos trechos seguintes, as palavras destacadas em negrito são cantadas com essa alteração vocal. Podemos notar a presença desses três sentimentos mencionados acima que se alternam ou se combinam para impulsionar cada um dos versos.

[3'18' '] Solitária na floresta de concreto e aço

[3'30', A garoa rasga a carne é a Torre de Babel

[3'33', Família brasileira, dois contra o mundo

[3'42'”] O bastardo, mais um filho pardo, sem pai

[4’25'] Ginga e fala gíria - gíria, não, dialeto

[4'40''] Cola o pôster do Tupac aí, que tal, que cê diz?

[4'43''] Sente o negro drama, vai, tenta ser feliz

[5'11'’] Aquele que você odeia amar nesse instante

Pele parda, e ouço o funk, vim de onde vem os diamante?

[5'17'’] Da lama. Valeu, mãe, negro drama

${ }^{96}$ In: CD Nada como um dia após o outro dia (chora agora) (2002) 
Assim, muito sutilmente, me parece que a intensidade e a altura (frequência) mais elevada da voz de Mano Brown correspondem a certo teor de passionalização. Essa diferença de altura e intensidade entre as duas partes da canção também poderia sugerir a utilização do recurso passional que Tatit denomina de transposição (quando temos a segunda parte da canção toda num registro mais elevado da tessitura). Obviamente, não se trata do mesmo caso típico de transposição observado em canções como Travessia (Milton Nascimento e Fernando Brandt) ${ }^{97}$. Entretanto, tendo em vista a "só menos" musicalização do rap, ocorrências como essa (a diferença entre o canto mais contido de Edy Rock e o canto mais intenso de Mano Brown) saltam aos olhos e ganham sentido de significativa passionalização. Outro aspecto interpretativo importante para a análise das diferenças entre as dicções dos dois MC's nessa canção é a maneira como cada um utiliza a respiração no canto. A parte cantada por Edy Rock é mais rarefeita. Notamos a presença de frases mais curtas e de um maior número de espaços de retomada do ar. No geral, o rapper canta um verso por respiração. Na parte interpretada por Mano Brown, ao contrário, há um número bem mais elevado de frases longas cantadas em uma única respiração. Encontramos ao todo oito ocorrências. Interessante notar que praticamente os três primeiros trechos cantados por ele (desconsiderando as palavras "rosto e coração") são realizados cada um em um só fôlego. Observamos assim o alto grau de tensão com que se inicia a sua interpretação.

[3'15'’] Uma negra e uma criança nos braços

Solitária na floresta de concreto e aço

Veja (...)

[3'21'’] (...) olha outra vez o rosto na multidão

A multidão é um monstro sem (...)

[3'27'’] Ei, São Paulo, terra de arranha-céu

A garoa rasga a carne, é a Torre de Babel

[4'07'’] Seu jogo é sujo e eu não me encaixo

Eu sou problema de montão, de carnaval a carnaval

Eu vim da selva, sou leão (...)

[4'46'] Ei, bacana, quem te fez tão bom assim

O que cê deu, o que cê faz, o que cê fez por mim?

[4'55', $](\ldots)$ kit

De esgoto a céu aberto e parede madeirite

\footnotetext{
${ }^{97}$ Exemplo de transposição sempre mencionado por Luiz Tatit em suas aulas na Faculdade de Filosofia, Letras e Ciências Humanas da USP.
} 
De vergonha eu não morri (...)

[5'01'’] (...) eis-me aqui

Você? Não, cê não passa quando o mar vermelho abrir

Eu sou o Mano, homem duro do gueto, o Brown (...)

[5'11', ] Aquele que você odeia amar nesse instante

Pele parda, e ouço o funk (...)

Na entoação do verso "O que cê deu, o que cê faz, o que cê fez por mim?" há um evento sonoro significativo. A última palavra é alongada e emitida com uma espécie de glissando. Esse, em parte causado pelo término do ar (o que impossibilitou a sustentação da nota), também nos indica certo esgotamento do sujeito tendo em vista o descaso em relação a sua realidade precária. Nesse pequeno gesto, observamos a expressão de um sofrimento acumulado. Nesse sentido, ainda que o rap represente um ponto extremo da incorporação da entoação da fala na canção popular, constatamos que há espaço para uma possível passionalização dentro dessa figurativização predominante. A distorção e as frases alongadas, realizadas em um só fôlego, no canto de Mano Brown podem representar indícios desse fenômeno, pois sua voz, além da fala agressiva, também exprime o sofrimento do sujeito. Como mencionamos anteriormente, este trabalho busca avaliar como atuam os pequenos gestos musicais dentro de uma canção como essa. Para considerarmos a possibilidade desses recursos de interpretação (o uso de região mais aguda no canto, a intensidade, a alteração timbrística da voz, a respiração) ganharem valor de passionalização. Se no rap dificilmente veremos o MC cantando melodias passionais usuais podemos investigar se outros recursos musicais e interpretativos (como os elencados acima) são capazes de assumir essa função passional. Mesmo que representem elementos mínimos. Podemos resumir o que observamos acima em um quadro que articula a sintaxe intensiva e a sintaxe extensiva, respectivamente, a partir da tonicidade ${ }^{98}$ (tônico/átono) e da extensão (concentrado/difuso). Dessa maneira, podemos localizar a parte cantada por Mano Brown numa região mais tônica do que a parte interpretada por Edy Rock, situada numa região mais átona. Importante sublinhar que a maior tonicidade do canto de Brown faz com que sua execução seja mais concentrada, diferentemente do canto de Edy Rock, mais difuso. Como vimos acima, Brown respira menos e encadeia frases longas numa única tomada de ar, deixando os versos menos espaçados.

\footnotetext{
${ }^{98}$ In: ZILBERBERG (2011)
} 


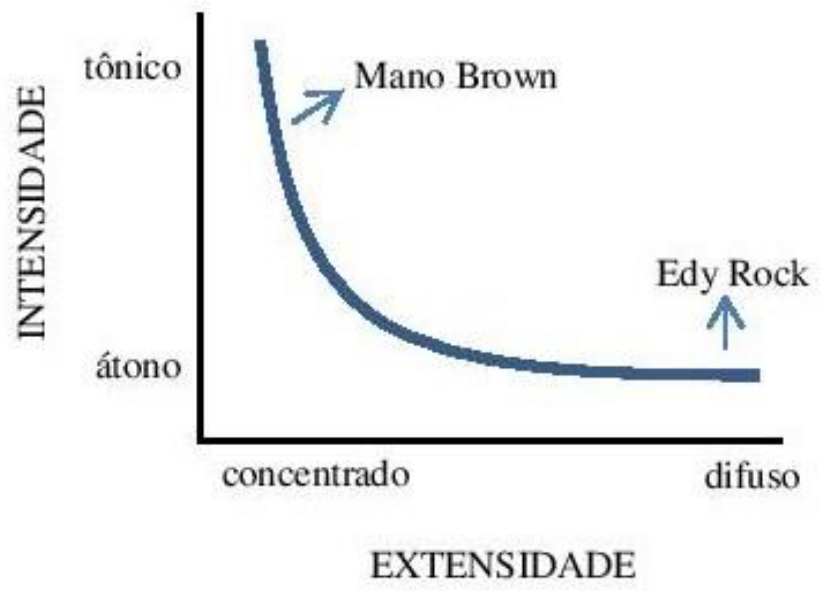

Figura 3.2-36: Comparação entre o canto de Mano Brown e Edy Rock em Negro Drama.

Podemos observar no universo do rap diversas maneiras de incorporar elementos de passionalização. Como já mencionamos nesse capítulo, são exemplos os vocais agudos da cantora Maria Rita em Brasil com $P$ do grupo GOG (figura 3.2-11), a maneira de entoar a letra em Fórmula mágica da paz dos Racionais MC's (figura 3.218) ou mesmo canções inteiras como no caso de Não existe amor em SP do rapper Criolo. São características formais que condizem com o teor de grande parte das letras: a disjunção em relação aos valores como dignidade e melhores condições de vida para a população pobre. Esse estado disjuntivo possibilita então que os elementos passionais participem das canções de alguma maneira. Vejamos, no caso de Negro Drama, qual o conteúdo da letra que fundamenta os elementos musicais passionais comentados acima. Como verificamos, a interpretação de Mano Brown é visivelmente mais tensa e inflamada do que o canto de Edy Rock (mesmo que ambos sejam explicitamente agressivos). A nosso ver, é o próprio conteúdo do texto de cada uma dessas partes que justifica as diferentes dicções dos dois MC's. Primeiramente, é significativo assinalar que Brown inicia sua interpretação cantando o que seria a sua história pessoal, a partir de sua infância.

Crime, futebol, música, caralho,

Eu também não consegui fugi disso aí.

Eu sou mais um.

Forrest Gump é mato,

Eu prefiro conta uma história real,

Vô conta a minha 
Esse sujeito que se presentifica na letra da canção revela um envolvimento diferenciado com o que está sendo cantado, já que insere maior quantidade de dados pessoais ao texto, o que pode tornar um pouco mais pronunciada a sua carga emotiva. No entanto, acreditamos que a razão principal dessa diferença interpretativa entre os dois artistas é o fato de que a interlocução com a figura do "senhor de engenho" é claramente mais enfatizada na segunda parte da canção. Mano Brown, enunciador, se dirige ao seu enunciatário com maior frequência e de forma mais contundente. Ao todo (sem contar o trecho final falado), destacamos dezenove versos em que o rapper interpela agressivamente a elite econômica brasileira, sublinhando a sua herança histórica ligada à escravidão, já que denomina de "senhor de engenho" o seu interlocutor.

Ei, senhor de engenho, eu sei bem quem você é

Sozinho cê num guenta, sozinho cê num entra a pé

Cê disse que era bom e a favela ouviu

(...)

Admito, seus carro é bonito, é, e eu não sei fazer

(...)

Seu jogo é sujo e eu não me encaixo

(...)

Eu vim da selva, sou leão, sou demais pro seu quintal

(...)

Inacreditável, mas seu filho me imita

No meio de vocês, ele é o mais esperto

(...)

Esse não é mais seu, ó [assovio], subiu

Entrei pelo seu rádio, tomei, cê nem viu

Nós é isso, aquilo, o quê, cê não dizia?

Seu filho quer ser preto, há, que ironia

Cola o pôster do Tupac aí, que tal, que cê diz?

Sente o negro drama, vai, tenta ser feliz

Ei, bacana, quem te fez tão bom assim

O que cê deu, o que cê faz, o que cê fez por mim?

Eu recebi seu ticket, quer dizer, kit

(...)

Você? Não, cê num passa quando o mar vermelho abrir

(...) 
Aquele que você odeia amar nesse instante

Edy Rock, por sua vez, se dirige diretamente ao seu interlocutor apenas três vezes:

Você deve tá pensando o que você tem a ver com isso

(...)

Olha quem morre, então, veja você quem mata

(...)

Olha o castelo e não foi você quem fez? Cuzão!

Assim, tendo em vista o fato de Mano Brown projetar seu enunciatário de forma mais contundente no discurso, justifica-se o maior grau de agressividade em sua interpretação. Seu maior nível de tonicidade. Em decorrência disso, observamos a presença dos elementos de passionalização mencionados anteriormente. Na primeira parte, ao contrário, mais do que se dirigir diretamente à elite (embora a mensagem geral seja a ela endereçada), Edy Rock estabelece um diálogo com a sua própria comunidade. Observamos a presença de nove versos em que o rapper parece falar aos próprios $\operatorname{manos}^{99}$ :

Nego drama, eu sei quem trama e quem tá comigo

(...)

Eu sou irmão dos meus trutas de batalha

(...)

Quem teve lado a lado e quem só ficou na bota

(...)

Do quem é quem, dos manos e das minas fracas

(Hum) Negro Drama de estilo

Pra ser, se for, tem que ser, se temer é milho

(...)

Falo pro mano que não morra e também não mate

O tique-taque não espera, veja o ponteiro

Essa estrada é venenosa e cheia de morteiro

\footnotetext{
${ }^{99} \mathrm{E}$ o único momento em que Mano Brown se dirige diretamente aos indivíduos de sua comunidade (em sua parte cantada) é ao final, quando agradece sua mãe (o que de certa forma também se relaciona a sua esfera pessoal).
} 
Assim, parece haver um teor maior de conscientização na primeira parte de Negro drama e uma carga maior de agressão na segunda parte. O efeito geral dessa obra é, sem dúvida, a afronta em relação à elite brasileira. Uma postura defendida pelo grupo desde o início de sua carreira. Um aspecto central em grande parte de suas canções:

Modificar a auto-imagem e o comportamento de todos os negros pobres do Brasil: é o fim da humildade, do sentimento de inferioridade que tanto agrada a elite da casa grande, acostumada a se beneficiar da mansidão - ou seja, do medo - de nossa 'boa gente de cor (KEHL, 2000: 213)

Por fim, o último recurso musical que gostaríamos de comentar se refere à inserção, nos momentos finais do canto de Edy Rock e Mano Brown ${ }^{100}$, de uma voz feminina aguda sobreposta às duas falas do MC. Por se situar em uma região elevada da tessitura e apresentar durações mais alongadas, essa voz ganha um sentido evidente de passionalização, sugerindo sofrimento em seu canto chorado. Essa voz feminina atua sobre o trecho falado por Mano Brown como uma espécie de reverberação passional do que foi cantado anteriormente, como um reflexo do sofrimento presente ao longo de toda a letra.

Enfim, ainda que a figurativização predomine em Negro Drama, podemos observar que há elementos de passionalização muito significativos. Constatamos, por outro lado, que esse fator passional que restabelece a musicalização atua sempre em consonância com o assunto disfórico da letra. Notamos algo semelhante no segundo capítulo dessa pesquisa, por exemplo, com os motivos rítmicos tematizantes de Negro Drama $^{101}$ : ainda que mais musicalizados, formam unidades entoativas relevantes, configurando o modo de dizer agressivo do rapper Mano Brown e garantindo a eficácia da comunicação. Da mesma forma, destacamos esses sutis elementos de passionalização observados na segunda parte da canção: a região de frequência mais elevada sugerindo o recurso da transposição, a maior intensidade do canto, a alteração timbrística da voz e o menor número de respirações do $\mathrm{MC}$ gerando menor espaçamento entre as frases. Todos esses recursos estão igualmente em consonância com o conteúdo disjuntivo da letra.

\footnotetext{
${ }^{100}$ De 2'50' à 3'15', e de 5'24'" à 6'51', respectivamente.

${ }^{101}$ Figura 2.2-14 do segundo capítulo, dedicado à tematização.
} 


\section{Conclusão}

O rap é, sem dúvida, um dos gêneros artísticos mais presentes na cultura brasileira atual. A discussão em torno do esgotamento da canção popular levantado pelo compositor Chico Buarque em dezembro de 2004 estava centrada no aparecimento do rap. Atualmente, ele ocupa um importante espaço na mídia e a todo o momento surgem novos grupos e MC's. Além disso, o modo como esses cancionistas abordam os temas da violência nas grandes cidades e da injustiça social, sob a perspectiva da população pobre e com forte postura de confronto, é fato inédito na história da arte brasileira.

Por tudo isso, acreditamos na importância de uma investigação sistemática da sua linguagem propriamente dita. Ao longo dessa dissertação, pudemos realizar associações significativas entre as questões frequentemente levantadas pelos estudos historiográficos e sociológicos e os aspectos composicionais do rap. Isto é, pudemos detectar no próprio artesanato do gênero a sua força social.

No primeiro capítulo, constatamos a presença de níveis muito sutis de musicalização, encontrando nuances até mesmo nas falas diretas observadas em diversos exemplos. Em relação ao canto dos $\mathrm{MC}$ 's, ao examinar grande parte da produção do rap brasileiro, pudemos constatar que todos apresentam significativa uniformidade rítmica: ora observamos a divisão regular da letra em quatro semicolcheias, ora a divisão alternada com figuras pontuadas e simples (longas e breves). Além disso, verificamos que a velocidade da pulsação se situa geralmente entre 73 e 96 bpm. Vimos que essa configuração melódica uniforme, além do fato de o cantor emitir com o registro próximo à voz falada, pode ser a razão pela qual o ouvinte não é capaz de identificar motivos musicais relevantes. Nesse sentido, escutamos o rap como um bloco homogêneo com menor estabilização musical. Ou seja, embora as sílabas da letra sejam organizadas regularmente no tempo, essa regularidade quase absoluta faz com que, paradoxalmente, o ouvinte não a perceba. No entanto, observamos igualmente ocorrências muito interessantes em relação ao parâmetro altura. Por vezes o MC estabiliza notas musicais ou altera a região de frequência e isso corresponde a uma tensividade exigida pela letra. $\mathrm{O}$ canto situado em região mais aguda pode ser indício de uma fala mais nervosa, de uma emissão mais intensa e agressiva, por exemplo. Como comentamos acima, pudemos demonstrar que a força política do rap se encontra na sua própria linguagem cancional e que o processo figurativo, por sua proximidade em 
relação ao registro da língua oral, mostra-se como o mais adequado ou natural para a transmissão das mensagens dos MC's. A desigualdade social estimula a contestação e esse questionamento é mais eficiente quando realizado por meio da figurativização. A proximidade com a fala garante o seu efeito de verdade, e consequentemente, a força da denúncia. Além disso, vimos o quanto esse processo cancional se relaciona a aspectos tão característicos do hip hop. Por um lado, proporciona a aproximação entre o artista e o público, que dividem o mesmo registro de voz. Por outro, entre o compositor e o intérprete, já que a predominância figurativa, ao explicitar um modo de dizer (a dicção de cada MC) produz uma individualidade verbal e essa maneira de entoar muitas vezes constitui a própria composição.

No segundo capítulo, foi possível observar como a presença da tematização traz uma interessante tensão para o rap. Se, por um lado, há uma reiteração rítmica que convida à dança e sugere valores eufóricos, por outro, o conteúdo disjuntivo de grande parte das letras não permite que o sentimento de felicidade plena prevaleça. Realizamos uma descrição detalhada da construção das bases do DJ e constatamos uma forte semelhança na instrumentação e na composição dos raps em geral. Percebemos que as suas características de tematização podem ser influência das canções do repertório da soul music norte americana: de maneira explícita, com as apropriações realizadas pelos DJ's para a composição de seus samples e, de forma mais sutil, a partir da constituição musical das bases (quando, por exemplo, assinalamos a semelhança entre o desenho rítmico da bateria em canções de James Brown e o arranjo instrumental de raps brasileiros). Pudemos notar o trabalho sofisticado do DJ, sempre atento ao conteúdo da letra e à maneira de entoar do MC, quando analisamos as supressões de trechos de linhas instrumentais com o objetivo de sublinhar certas palavras, transições ou terminações. Após explorar esses indícios de características tematizantes na constituição do arranjo, passamos a examinar a tematização propriamente dita, isto é, sua presença no canto do MC. Primeiramente, vimos que a melodia do rap apresenta uma regularidade rítmica marcante, o que já significa uma investida temática relevante. Em seguida, destacamos a importância crucial da rima que, embora minimamente, representa um fator de ordenação musical que estabiliza o texto verbal. Percebemos a menor presença dos refrãos e investigamos as possíveis razões para esse fato. Notamos, por um lado, que o refrão, como um tipo de construção musical baseada na repetição, se distancia do ímpeto figurativo dos rappers (que adotam um registro mais falado para transmitirem suas mensagens com maior eficácia). Assim, investir na reiteração de 
algumas frases é, de certo modo, sair desse registro, pois na língua oral não se costuma usar esse tipo de procedimento. Por outro lado, a ausência de refrãos é muito significativa na medida em que grande parte das letras possui conteúdo predominantemente disjuntivo. Se o assunto geralmente se refere à dificuldade do sujeito (população pobre) de alcançar seu objeto (condições de vida), a forma musical adotada dificilmente será conjuntiva. Observamos, no entanto, alguns raps que trabalham com refrãos ou reiterações tematizantes. Ao examinar esses casos específicos, vimos que há neles um teor momentâneo de conjunção. São instantes da narrativa em que há uma pequena pausa das adversidades, momento em que o sujeito parece gozar de algum tipo de relação eufórica com o mundo. Contudo, tendo em vista a predominância do teor disjuntivo em grande parte das obras, essa pausa eufórica geralmente tem duração muito limitada. Outra característica observada é a presença de certos desenhos rítmicos reiterados pelos MC's que, ainda que pouco mais distantes da fala coloquial, geram unidades entoativas plausíveis e ligadas ao mesmo conteúdo de denúncia observado nas partes mais figurativas. Assim como a coreografia do break que pode representar a liberdade do corpo, um alívio das tensões acumuladas ou uma resposta gestual a uma situação opressiva. Enfim, os aspectos ligados à tematização estudados nessa dissertação também podem se relacionar ao mesmo ímpeto político tão característico do hip hop. Ou seja, sua força contestatória também está nas suas rimas e ritmos. A estabilização musical fortalece o discurso dos $\mathrm{MC}$ 's, pois o torna mais duradouro, em contraposição à efemeridade da fala do dia a dia. Além disso, a forma estável empregada atrai o ouvinte e o faz mais receptivo ao que é dito na obra.

No último capítulo, analisamos a presença de elementos passionalizantes nas melodias dos refrãos, nos vocais femininos, nas linhas instrumentais e, principalmente, na própria entoação do MC. Destacamos exemplos em que as notas são mais alongadas e chegam a se estabilizar em alturas definidas de maneira mais contundente, muitas vezes em região aguda. $\mathrm{O}$ cantor entoa a letra de maneira plangente e atenua as suas articulações (os ataques silábicos) para que a duração de cada nota seja ressaltada. Em Negro drama, observamos até mesmo o uso de uma região mais elevada de frequência e uma maior intensidade do canto, com alterações timbrísticas significativas e menor número de respirações. Essa forma musical passionalizante está absolutamente de acordo com o conteúdo disjuntivo da letra. O interessante é notarmos que se o estado de disforia retratado em grande parte do repertório gera, por um lado, a revolta e a denúncia, por outro, produz também um marcante teor de lamento. Assim, se o processo 
figurativo é o veículo mais apropriado para a contestação, a passionalização também está presente, pois essa revolta é resultado de uma situação de sofrimento extremo. É igualmente importante destacar que os aspectos passionais ocasionados pelo estado disjuntivo que predomina na maioria das letras têm raízes mais profundas na história do rap. Para compor suas bases, os DJ's sempre se apropriaram de obras da tradição da soul music, cujas canções possuem aspectos claramente passionais. Pudemos localizar nesse repertório da música negra os elementos referidos acima, o que pode configurar uma provável origem da passionalização no rap. Notamos que as vozes da black music sempre valorizaram o alongamento das durações, a desaceleração do andamento e conteúdos ligados às disjunções amorosas. Desse modo, pudemos notar que o rap, além da figurativização e tematização predominantes, também apresenta elementos de passionalização importantes para o sentido final da obra.

Finalmente, acreditamos que o estudo do rap a partir da teoria da linguagem cancional pode ser extremamente proveitoso para a compreensão mais ampla desse tipo de canção. Como comentamos anteriormente, não pretendemos desconsiderar as características sociais do rap, nem seu contexto histórico. Pelo contrário, desejamos somente assinalar a importância de nos debruçarmos sobre a sua matéria artística, para que os fatores externos à obra sejam devidamente fundamentados. Por outro lado, se há uma dificuldade encontrada nos meios acadêmicos de entendimento da canção popular enquanto gênero artístico específico e de valorização de sua construção estética independentemente da música, essa tarefa se torna ainda mais custosa no caso do rap. Mais uma razão para levarmos adiante tal estudo. Tricia Rose, uma das principais especialistas no assunto, relata uma experiência pessoal que ilustra muito bem essa dificuldade de compreensão da forma artística do rap que perdura até os dias de hoje.

Na primavera de 1989, eu estava falando animadamente com um professor de etnomusicologia sobre a música rap e os objetivos deste projeto. Ele gostou de algumas de minhas ideias e decidiu apresentar e descrever o meu projeto para o chefe do departamento de música. No final de sua apreciação o chefe do departamento se levantou e anunciou casualmente: "Bem, você deve estar escrevendo sobre o impacto social e as letras políticas do rap, porque não há nada o que dizer sobre a música". Minha expressão de surpresa e hesitação verbal deu-lhe tempo para explicar sua posição. Ele me explicou que, embora a 
música fosse muito simples e repetitiva, as histórias contadas nas letras possuíam valor social. (ROSE, 1994: 62) $)^{102}$

O desprestígio em relação ao valor estético do rap, além dos fatores sociais de desvalorização da cultura da população pobre, está ligado justamente à ignorância em relação ao verdadeiro processo criativo do compositor de canções. Sob a ótica musical, essas obras não parecem apresentar valor significativo. Ao propormos uma pesquisa que estude a sua linguagem específica, acreditamos que esse tipo de incompreensão possa ser aclarado. Poderemos, dessa maneira, demonstrar que a sua forma menos musicalizada é justamente a sua característica estética mais ousada e eficaz, extremamente relevante ao seu objetivo de transmitir os conteúdos contestatórios. Então, poderemos entendê-lo como um gênero artístico altamente complexo, rico em nuances cancionais que muitas vezes passam despercebidas a quem equivocadamente pretende abordá-lo com ferramentas de análise inapropriadas ou insuficientes.

\footnotetext{
${ }^{102}$ In the spring of 1989, I was speaking animatedly with an ethnomusicology professor about rap music and the aims of this project. He found some of my ideas engaging and decided to introduce me and describe my project to the chairman of his music department. At the end of his summary the department head rose from his seat and announced casually, "Well, you must be writing on rap's social impact and political lyrics, because there is not to the music". My surprised expression and verbal hesitation gave him time to explain his position. He explained to me that although the music was quite simple and repetitive, the stories told in the lirycs had social value. (ROSE, 1994: 62)
} 


\section{Referências bibliográficas}

BARROS, Diana Luz Pessoa de. Teoria do discurso: fundamentos semióticos. São Paulo: Humanitas, 2001.

BARROS E SILVA, Fernando de. "O Fim da canção (em torno do último Chico Buarque)". In: Revista Serrote $n^{\circ} 3$. São Paulo: Instituto Moreira Salles, novembro de 2009.

BARTHES, Roland. O Óbvio e o Obtuso. São Paulo: Edições 70 (coleção Signos 42), 1984.

BÉTHUNE, Christian. Le rap: une esthétique hors la loi. Paris : Éditions Autrement, 1999.

BUARQUE, Chico. Entrevista ao jornal Folha de São Paulo. Caderno Ilustrada. São Paulo, 26 de dezembro de 2004.

CANDÉ, Roland de. História universal da música. Volume I e II. $2^{\text {a }}$ edição. São Paulo: Martins Fontes, 2001.

FIORIN, José Luiz. Elementos de análise do discurso. São Paulo: Contexto, 2008.

GARCIA, Walter. “'Diário de um detento’: uma interpretação”. Em: Lendo música, 10 ensaios sobre 10 canções. Arthur Nestrovsky (org.). São Paulo: Publifolha, 2007.

GARCIA, Walter. "Ouvindo Racionais MC's" - In: Teresa revista de literatura brasileira, n. 4 e 5. São Paulo, Área de Literatura Brasileira - DLCV-FFLCH/Editora 34, 2003.

GREIMAS, Algirdas Julien \& COURTÉS, Joseph. Dicionário de semiótica. São Paulo: Contexto, 2012. 
GRIFFITHS, Paul. A música moderna. Rio de Janeiro: Jorge Zahar Ed., 1998.

HARNONCOURT, Nikolaus. O diálogo musical: Monteverdi, Bach e Mozart. Rio de Janeiro: Jorge Zahar Ed., 1993.

KEHL, Maria Rita. "A fratria órfã: o esforço civilizatório do RAP na periferia de São Paulo” In: KEHL, Maria Rita (org.), Função fraterna. Rio de Janeiro: Relume Dumará, 2000.

NIELSON, Erik \& KUBRIN, Charis E. Artigo traduzido e publicado no jornal O Globo em 17/01/2014. In: http://oglobo.globo.com/mundo/letras-de-rap-em-julgamento-nosestados-unidos-11318331

OLIVEIRA, Sílvia Cristina de. Para uma análise sociossemiótica do discurso presente no texto da música rap. Tese de doutorado. FFLCH - USP. São Paulo, 1999

PALISCA, Claude V. \& GROUT, Donald J. História da música ocidental. $4^{\mathrm{a}}$ edição. Lisboa: Gradiva, 2007.

ROSE, Tricia. Black Noise: Rap music and Black Culture in Contemporary America. Middletown: Wesleyan, 1994.

ROUSSEAU, Jean-Jacques, Ensaio Sobre a Origem das Línguas. In: Coleção Os Pensadores. São Paulo: Abril cultural, 1978.

SANTOS, Rosana Aparecida Martins. O estilo que ninguém segura: Mano é mano! Boy é boy! Boy é mano? Mano é mano? Reflexão crítica sobre os processos de sociabilidade entre o público juvenil na cidade de São Paulo na identificação com a musicalidade do Rap Nacional. Dissertação de Mestrado, ECA-USP, 2002.

TATIT, Luiz. A canção: eficácia e encanto. São Paulo: Atual, 1986.

TATIT, Luiz. O Cancionista. São Paulo: Edusp, 2002. 
TATIT, Luiz. O século da canção. Cotia: Ateliê Editorial, 2004.

TATIT, Luiz. Todos entoam: ensaios, conversas e canções. São Paulo: Publifolha, 2007.

TATIT, Luiz \& LOPES, Ivã Carlos. Elos de melodia e letra: análise semiótica de seis canções. Cotia, SP: Ateliê Editorial, 2008.

TEPERMAN, Ricardo Indig. Tem que ter suingue: batalhas de freestyle no metrô Santa Cruz. Dissertação de mestrado. FFLCH - USP. São Paulo, 2011.

TEPERMAN, Ricardo Indig. Se liga no som - as transformações do rap no Brasil. São Paulo, ClaroEnigma, no prelo.

TOOP, David. Rap Attack 3: African rap to global hip hop. London: Serpent's Tail, 2000 .

VIANNA, Hermano. O mundo funk carioca. Rio de Janeiro: Jorge Zahar Editor Ltda, 1988.

ZILBERBERG, Claude. Elementos de semiótica tensiva. Trad. Ivã Carlos Lopes, Luiz Tatit e Waldir Beividas. São Paulo: Ateliê Editorial, 2011.

ZWILLING, Carin. "A expressão dos afetos na canção renascentista". In: Arte $e$ Cultura Santa Marcelina ano1, n. 1. São Paulo: FASM, 2007. 
CD (exemplos musicais) 


\section{Roteiro e discografia dos exemplos musicais}

\section{Figurativização}

01- Ladeira da Preguiça (Gilberto Gil) In: Programa Ensaio Elis Regina (1973)

02- Beatriz (Edu Lobo/Chico Buarque) In: O grande circo místico (1983)

03- Diferentemente (Caetano Veloso) In: Zii e zie (2009)

04- Mambembe (Chico Buarque) In: Quando o carnaval chegar (1972)

05- Que maravilha (versão de Jorge Ben Jor) In: Negro é lindo (1971)

06- Que maravilha (versão de Toquinho)

07- E estamos conversados (Arnaldo Antunes/Paulo Tatit) In: O silêncio BMG (1996)

08- 12 de outubro (Racionais MC's) In: Nada como um dia após o outro dia Cosa Nostra (2002)

09- Homem na estrada (Racionais MC's) In: Raio X do Brasil (1993)

10- Estilo Cachorro (Racionais MC's) In: Nada como um dia após o outro dia Cosa Nostra (2002)

11- V.L parte 2 (Racionais MC's) In: Nada como um dia após o outro dia Cosa Nostra (2002)

12- Jesus chorou (Racionais MC's) In: Nada como um dia após o outro dia Cosa Nostra (2002)

13- Fone (intro) (Racionais MC's) In: Nada como um dia após o outro dia Cosa Nostra (2002)

14- Crime vai e vem (Racionais MC's) In: Nada como um dia após o outro dia Cosa Nostra (2002)

15- V.L parte 2 (Racionais MC's) In: Nada como um dia após o outro dia Cosa Nostra (2002)

16- Rapaz Comum (Racionais MC's) In: Sobrevivendo no inferno. Cosa Nostra (1997)

17- Periferia é periferia (em qualquer lugar)... (Racionais MC's) In: Sobrevivendo no inferno. Cosa Nostra (1997)

18- Rap é compromisso (Sabotage) In: Rap é compromisso Cosa Nostra (1999)

19- Voz ativa (versão rádio) (Racionais MC's) In: Escolha o seu caminho (1992)

20- Capítulo 4, versículo 3 (Racionais MC's) In: Sobrevivendo no inferno. Cosa Nostra (1997)

21- Corpo fechado (Thaíde e DJ Hum) In: Hip-Hop Cultura de Rua (1988)

22- Respeito é pra quem tem (Sabotage) In: Rap é compromisso Cosa Nostra (1999)

23- Pânico na zona sul (Racionais MC's) In: Holocausto urbano. RDS/Zimbabwe (1990)

24- Mind Power (James Brown) In: The Payback (1973)

25- Tempos difíceis (Racionais MC's) In: Holocausto urbano (1990)

26- Papa Don't Take No Mess (James Brown) In: Hell (1974)

27- V.L. Parte 2 (Racionais MC's) In: Nada como um dia após o outro dia Cosa Nostra (2002)

28- V.L. Parte 2 (Racionais MC's) In: Nada como um dia após o outro dia Cosa Nostra (2002)

29- Diário de um detento (Racionais MC's) In: Sobrevivendo no inferno Cosa Nostra (1997)

30- Negro drama (Racionais MC's) In: Nada como um dia após o outro dia Cosa Nostra (2002)

31- Melô do Tagarela (Arnaud Rodrigues) RCA (1979)

32-Rapper's Delight (Sugarhill Gang) In: Sugarhill Gang (1980)

33- Pânico na zona sul (Racionais MC's) In: Holocausto urbano (1990)

34- Voz ativa (versão rádio) (Racionais MC’s) In: Escolha o seu caminho (1992) 
35- Introdução (Racionais MC's) In: Raio X do Brasil (1993)

36- Genesis (intro) (Racionais MC's) In: Sobrevivendo no inferno Cosa Nostra (1997)

37- Sou + você (Racionais MC’s) In: Nada como um dia após o outro dia Cosa Nostra (2002)

38- De volta à cena (Racionais MC's) In: Nada como um dia após o outro dia Cosa Nostra (2002)

39- Trutas e quebradas (Racionais MC's) In: Nada como um dia após o outro dia Cosa Nostra (2002)

40- Da ponte pra cá (Racionais MC's) In: Nada como um dia após o outro dia Cosa Nostra (2002)

\section{Tematização}

41- Vem morena - Luiz Gonzaga In: Luiz Gonzaga MPB no JT (2011)

42- Águas de março - Tom Jobim In: Elis \& Tom (1974)

43- Do leme ao pontal 1 - Tim Maia In: O melhor de Tim Maia (2009)

44- Do leme ao pontal 2 - Tim Maia In: O melhor de Tim Maia (2009)

45- Corpo Fechado - Thaíde e DJ Hum In: Hip-Hop Cultura de Rua (1988)

46- Zoião - Emicida In: O Glorioso Retorno de Quem Nunca Esteve Aqui (2013)

47- Respeito é Pra Quem Tem - Sabotage In: Rap é compromisso Cosa Nostra (1999)

48- Diário de um Detento - Racionais MC's In: Sobrevivendo no inferno Cosa Nostra (1997)

49- Funky President (People Its Bad) - James Brown In: Reality (1974)

50- Papa Don't Take No Mess - James Brown In: Hell (1974)

51- Negro Drama (acompanhamento) - Racionais MC's In: Nada como um dia após o outro dia Cosa Nostra (2002)

52- Negro Drama (completo) - Racionais MC's In: Nada como um dia após o outro dia Cosa Nostra (2002)

53- Eu Sou 157 - Racionais MC's In: Nada como um dia após o outro dia Cosa Nostra (2002)

54- Capítulo 4 Versículo 3 - Racionais MC's In: Sobrevivendo no inferno Cosa Nostra (1997)

55- A Vítima 1 - Racionais MC's In: Nada como um dia após o outro dia Cosa Nostra (2002)

56- A Vítima 2 - Racionais MC's In: Nada como um dia após o outro dia Cosa Nostra (2002)

57- A Vítima 3 - Racionais MC's In: Nada como um dia após o outro dia Cosa Nostra (2002)

58- Negro Drama - Racionais MC's In: Nada como um dia após o outro dia Cosa Nostra (2002)

59- Talvez seja querer demais - GOG In: Tarja preta (2004)

60- Nem tudo está perdido - Posse Mente Zulu In: Revolusom - A volta do tape perdido (2005)

\section{Passionalização}

61- Cantiga - Dorival Caymmi In: RCA Victor 800576 (1948)

62- Duas horas da manhã - Paulinho da Viola In: A dança da solidão (1972)

63- Levanta e Anda - Emicida In: O Glorioso Retorno de Quem Nunca Esteve Aqui (2013)

64- No Brooklin - Sabotage In: Rap é compromisso Cosa Nostra (1999)

65- Ninguém Sabe - Thaíde e DJ Hum In: Assim Caminha a Humanidade (2000)

66- Castelo Triste - Facção Central In: O Espetáculo do Circo dos Horrores (2006) 
67- Fórmula Mágica da Paz (refrão) - Racionais MC’s In: Sobrevivendo no inferno Cosa Nostra (1997)

68- Estágio Final - RZO In: Todos são manos (1999)

69- Passaporte Pro Inferno - Sistema Negro In: Renascendo das cinzas (2005)

70- Passageiro da Agonia - De Menos Crime In: O Revertério (2005)

71- Desconforto 2 - Posse Mente Zulu In: Revolusom - A volta do Tape Perdido (2005)

72- Sonho Meu - Xis In: Fortificando a Desobediência (2001)

73- Brasil com P - GOG In: DVD Cartão Postal Bomba (2007)

74- Deus abençoe a todos - Faces do Subúrbio In: Faces do Subúrbio (1998)

75- Noite de insônia - MRN In: Só se não quiser ser... (1994)

76- Soldado Morto - MV Bill In: Retrato (2012)

77- Território Leste - Consciência Humana In: Agonia do Morro (2003)

78- A Sina - SNJ In: O show deve continuar (2003)

79- O Resto Do Mundo 1 - Gabriel O Pensador In: Gabriel O Pensador (1993)

80- Fórmula Mágica da Paz - Racionais MC's In: Sobrevivendo no inferno Cosa Nostra (1997)

81- Não Existe Amor em SP - Criolo In: Nó na Orelha (2011)

82- Lost Someone - James Brown In: Greatest Hits (2009)

83- Cry On - Irma Thomas In: Sweet Soul Queen Of New Orleans (1978)

84- Ain't No Way - Aretha Franklin In: Lady Soul (1968)

85- It's Too Late - Wilson Pickett In: It's Too Late (1963)

86- Me Dê Motivos - Tim Maia In: O melhor de Tim Maia (2009)

87- Sr. Tempo Bom (completo) - Thaíde e DJ Hum In: Preste atenção (1996)

88- Sr. Tempo Bom - Thaíde e DJ Hum In: Preste atenção (1996)

89- Sr. Tempo Bom (refrão) - Thaíde e DJ Hum In: Preste atenção (1996)

90- Sr. Tempo Bom (vocal) - Thaíde e DJ Hum In: Preste atenção (1996)

91- O Resto Do Mundo (completo) - Gabriel O Pensador In: Gabriel O Pensador (1993)

92- O Resto Do Mundo (melodia instrumental 1) - Gabriel O Pensador In: Gabriel O Pensador (1993)

93- O Resto Do Mundo (melodia instrumental 2) - Gabriel O Pensador In: Gabriel O Pensador (1993)

94- O Resto Do Mundo (melodia instrumental do saxofone) - Gabriel O Pensador In: Gabriel O Pensador (1993) 


\section{Anexo}

\section{Nota de rodapé número 17}

Em Holocausto Urbano (1990), assinalamos a presença de trechos falados nas canções: Pânico na zona sul (de 0'00'” a 0'17', locução inicial de Edy Rock, Mano Brown e Ice Blue e de 3'50' a 4'12', locução final); Beco sem saída (de 2'21', a 2'32' e de 3'41 a 3'55', falas de Edy Rock); Hey boy (de 0'00', a 0'18', e de 3'32' a 3'49', falas de Mano Brown); Mulheres vulgares (de 0'00' a 0'28' e de 4'04' a 4'28', simulações de ligações telefônicas); Racistas otários (de 4'18'" a 4'’32',, discurso falado e risadas); Tempos difíceis (em 3'13' Edy Rock chama KL Jay antes de uma parte virtuosística do DJ).

Em Escolha o seu caminho (1992), um EP com duas canções e duas novas mixagens, destacamos: Voz Ativa, versão rádio (de 0'00" a 0'23" fala introdutória e de 3'08' a 3'24', fala de Mano Brown perguntando a Ice Blue); Voz Ativa, versão baile e Voz Ativa, a capella (de 3'32" a 3'43', fala de Mano Brown); Negro Limitado (de 0'00' a 0'15', de 0'35' a 0'40', de 1'56' a 2'07', de 4'15', a 4'20', e de 5'33'" a $5^{\prime} 47^{\prime}$, , trechos falados).

Em Raio X Brasil (1993), observamos: Introdução (faixa introdutória toda falada por Edy Rock); Fim de semana no parque (de 0'00' a 0'04', fala de Mano Brown, 3'25', fala de Mano Brown e de 5'42', a 6'06', fala do cantor Netinho respondida em seguida por Mano Brown); Parte II (de 0'00' a 0'49' e de 4'58' ao final, diálogo entre uma voz feminina e Edy Rock); Mano na porta do bar (de 2'10' a 2'30', inserção de diálogo com rapazes discutindo, de 4'19'" a 4'40', novo diálogo); Homem na estrada (em 2'07', fala de Edy Rock, em 6'53' fala de Mano Brown e de 8'17' ao final, locução jornalística); Juri Racional (em 1'42' e 1'53', trechos falados, de 2'07', a 2'20', fala de Mano Brown e de 4'13'” ao final, discurso falado de um juiz em um tribunal); Fio da navalha (de 0'00', a 0’33', falas iniciais dos rappers); Agradecimentos (faixa totalmente falada pelos rappers que vão tecendo agradecimentos).

Em Sobrevivendo no inferno (1997), notamos: Jorge da Capadócia (“Ogunhê”); Genesis (intro) (faixa toda falada por Mano Brown); Capítulo 4, versículo 3 (de 0’00' a 0'22', fala de Primo Preto e em 3'54', (fala); Tô ouvindo alguém me chamar (de 0'21', 
a 0'23', de 1'20', a 1'30', de 3'14', a 3'17', e em 3'21', e 10',53', (falas simulando situações de violência); Rapaz Comum (de 0'00' a 0'25', som ao fundo com locução de narrador esportivo e falas e em 1'06', e 1'22', (falas); faixa seis (...) totalmente instrumental; Diário de um detento (de 0'00', a 0'08', fala inicial de Mano Brown); Periferia é periferia (em qualquer lugar) (em 2'19', falas); Qual mentira vou acreditar (em 5'34', 6'00', 6'35', falas, e de 7'03', a 7'20', falas de Edy Rock e Mano Brown); Mágico de $O z$ (de 0'00', a 0'27', fala de criança e de 6'59', a 7'20', fala final de Edy Rock); Fórmula mágica da paz (de 3'34', a 3'43'” e de 8'54' até o final, fala de Mano Brown e em 4'07', nova fala); Salve (faixa toda falada pelos rappers).

Em Nada como um dia após o outro dia (2002), destacamos: Sou + você (faixa toda falada por Mano Brown); Vivão e vivendo (faixa toda falada com voz do rapper com timbre alterado alternando momentos mais instáveis de fala e momentos mais musicalizados, mais rimados e ritmados); V.L (intro) (faixa toda falada simulando personagens que procuram o rapper Mano Brown); V.L. (parte 1) (de 0'00', a 1'11', diálogos falados de Mano Brown com diversos interlocutores, de 2'55', a 3'17', diálogo telefônico de Mano Brown com amigo detento e de 4'37', até o final, novo diálogo); Negro Drama (de 2'57' a 3'12'" e de 5'25' a 6'25' (trechos falados de Mano Brown); A vítima (de 0'00', a 0'48', em 1'04', de 2'12', a 2'24', de 3'23'" a 3'33', de 4'27', a 4'32', de 5'51', a 5'53', e de 6'43'" ao final, diálogo de Edy Rock com variados interlocutores); Na fé firmão (em 2'34', 4'09'” e 4'48', interjeição e falas de interlocutor do rapper); 12 de outubro (faixa toda falada por Mano Brown); Eu sou 157 (em 4'44', de 5'18' a 5'29', e de 7'49', a 8'10', (fala de Mano Brown); A vida é desafio (de 0'00', a 0'52', de 3'45', a 4'02', e de 5'57', ao final, falas de Edy Rock e Afro-X); 1 por amor 2 por dinheiro (de 0'10'" a 0'16', de 2'00', a 2'05', e de 2'23' a 2'43', falas diversas). De volta à cena (de 0'09', a 0'24', fala inicial); Outros 500 (de 1'02"' a 1'05', vozes simulando cena de violência); Crime vai e vem (de 0'03'" a 0'23', em 1'35', de 1'41', a 2'00', de 3'27'' a 3'37', em 3'48', de 4'15', a 4'43', presença de diálogos e de 6'19', a 7'55', falas de programa jornalístico); Jesus chorou (0'51', 1'53', 2'11', 2'42', falas diversas); Fone (intro) (toda a faixa com conversas ao telefone e diálogos do rapper Ice Blue com outros interlocutores); Estilo cachorro (em 1'04', 1'07', 1'14', 1'17', 1'20', 1'23', 1'51', 2'01', 3'27', falas diversas); V.L parte 2 (de 0'00', a 0'12', fala inicial); Expresso da meia-noite (em 1'27', 1'35', 1'37', 4'24', e 4'50', interjeição e falas diversas); Trutas e quebradas (faixa totalmente falada em que cada um dos rappers faz dedicatórias e agradecimentos a 
amigos, familiares e outras comunidades de periferias brasileiras); Da ponte pra cá (de 0’00" a 0'45', início falado por locutor de rádio e em 7’30', fala final de Mano Brown). 